\title{
Site U1417
}

\author{
J.M. Jaeger, S.P.S. Gulick, L.J. LeVay, H. Asahi, H. Bahlburg, C.L. Belanger, G.B.B. Berbel, L.B. Childress, \\ E.A. Cowan, L. Drab, M. Forwick, A. Fukumura, S. Ge, S.M. Gupta, A. Kioka, \\ S. Konno, C.E. März, K.M. Matsuzaki, E.L. McClymont, A.C. Mix, C.M. Moy, J. Müller, A. Nakamura, \\ T. Ojima, K.D. Ridgway, F. Rodrigues Ribeiro, O.E. Romero, A.L. Slagle, J.S. Stoner, \\ G. St-Onge, I. Suto, M.H. Walczak, and L.L. Worthington ${ }^{2}$
}

\section{Chapter contents}

Background and objectives. . . . . . . . 1 Operations..................... 2 Lithostratigraphy..............4 Paleontology and biostratigraphy ....... 10 Stratigraphic correlation. . . . . . . . . 13 Geochemistry ................. 15 Physical properties ............. 20

Paleomagnetism ............... 23

Downhole logging .............. 24

Core-log-seismic integration. . . . . . . . . . 29

References...................... 32

Figures.................... 36

Tables.... . . . . . . . . . . . . . . . . . . . 109

'1Jaeger, J.M., Gulick, S.P.S., LeVay, L.J., Asahi, H., Bahlburg, H., Belanger, C.L., Berbel, G.B.B., Childress, L.B., Cowan, E.A., Drab, L., Forwick, M., Fukumura, A., Ge, S., Gupta, S.M., Kioka, A., Konno, S., März, C.E., Matsuzaki, K.M., McClymont, E.L., Mix, A.C., Moy, C.M., Müller, J., Nakamura, A., Ojima, T., Ridgway, K.D., Rodrigues Ribeiro, F., Romero, O.E., Slagle, A.L.,Stoner, J.S., St-Onge, G., Suto, I., Walczak, M.H., and Worthington, L.L., 2014. Site U1417. In Jaeger, J.M., Gulick, S.P.S., LeVay, L.J., and the Expedition 341 Scientists, Proc. IODP, 341: College Station, TX (Integrated Ocean Drilling Program). doi:10.2204/iodp.proc.341.103.2014

'Expedition 341 Scientists' addresses.

\section{Background and objectives}

Site U1417 is located in the distal Surveyor Fan in the Gulf of Alaska (Fig. F1). The area was originally drilled at Site $178(\sim 1.5$ $\mathrm{km}$ from Site U1417) during Leg 18 of the Deep Sea Drilling Project (DSDP) with $\sim 40 \%$ recovery, most of which is Late Pleistocene in age (Fig. F2). Site U1417 is $\sim 60 \mathrm{~km}$ from the Surveyor Channel, which delivers sediment to this site via overbank processes (Fig. F3).

Drilling targets were three major regional seismic boundaries and associated seismic sequences mapped by Reece et al. (2011) using reprocessed U.S. Geological Survey and 2004 high-resolution and 2008 crustal-scale seismic reflection data to correlate stratigraphic changes and fan morphology through time (Fig. F4). Sequences I and II exhibit layered, laterally semicontinuous reflectors consistent with distal submarine fan (turbiditic) deposition. Sequence III is thinly layered and contains reflectors that are laterally continuous, flatter, and smoother than those in the other sequences. Stratal relationships at the sequence boundaries are highly variable and greatly influenced by basement topography. Sequence II onlaps Sequence I in the areas where Sequence I exhibits topography, but it is conformable in other locations. Sequence III downlaps Sequence II in parts of the distal fan where both sequences pinch out farther from the Surveyor Channel sediment source. At Site U1417, Sequences I-III appear to be conformable (Fig. F3).

Site U1417 lies at the intersection of two crustal-scale seismic profiles acquired during the 2011 R/V Marcus Langseth U.S. Extended Continental Shelf project for the U.N. Law of the Sea (Fig. F5; Walton et al., submitted). The shallow primary target for Site U1417 is the Sequence II/III boundary from Reece et al. (2011), which has been mapped onto the 2011 profiles. This sequence boundary, which is mappable throughout the Surveyor Fan (Fig. F6), is proposed to represent an increase in sediment supply to the site as a result of an intensification of glaciation at the midPleistocene transition (MPT) and subsequent delivery to the site via the Surveyor Channel, ice-rafting, and hemipelagic/pelagic deposition. The deeper primary target is the Sequence I/II boundary (Reece et al., 2011), which was also mapped onto the 2011 data and which is proposed to correspond to the onset of tidewater glaciation and to the start of Surveyor Fan deposition in the late Miocene. Additional divisions of these sequences for the purpose of core-log-seismic integration are discussed in "Core-logseismic integration" and displayed in Figure F7. 
This site was chosen to provide a sedimentary record of Neogene glacial and tectonic processes occurring in the adjacent orogen (Fig. F8). All of Sequences II and III are estimated to correspond with this time period, which would include both the Miocene tectonic uplift of the St. Elias orogeny and the late Miocene to Pleistocene preglacial to glacial conditions, including the initiation of the northwestern Cordilleran ice sheet (NCIS), the intensification of Northern Hemisphere glaciation, and the potential intensification of glacial extent following the MPT. These sequences should also contain a provenance record reflecting the locus of sediment created during the exhumation and uplift of the St. Elias Mountains.

By drilling into Sequence I, Site U1417 allows examination of deposition prior to the onset of the sedimentation associated with establishment of the Surveyor Channel. The channel is proposed to have formed in response to increased sediment supply from the adjacent coastal mountains, the timing of which may correspond with the initiation of the NCIS (Reece et al., 2011). Sequence I includes several seismic facies (Fig. F7) that may yield clues into the changes in depositional setting from the late Oligocene (approximate age of basement) through the Miocene, as this site tectonically migrated northwest from somewhere near modern day British Columbia toward southern Alaska. These sediments should yield insight into the initial uplift of the St. Elias orogen, which provided the enhanced elevation needed for later glaciation.

The Sequence I/II boundary occurs at $\sim 330 \mathrm{~m}$ within the drilled interval at Site 178, within a section of fine-grained sand to silty turbidites and interbedded diatomaceous ooze and mud with increasing diamict upsection (Kulm, von Huene, et al., 1973; Reece et al., 2011). The Sequence I/II boundary was dated to be $\sim 5$ Ma by Reece et al. (2011), near the beginning of Glacial Interval A of Lagoe et al. (1993), based on ${ }^{40} \mathrm{Ar} /{ }^{39} \mathrm{Ar}$ dating of ash layers (Hogan et al., 1978) (Fig. F2). At $\sim 130 \mathrm{~m}$ at Site 178, the Sequence II/III boundary lies within an interval of changing fan lithology. The section from 96 to $141 \mathrm{~m}$ contains abundant diamict interbedded with silty clay and diatom-rich intervals, whereas the section from 141 to $280 \mathrm{~m}$ contains less diamict, much more silty clay, and fewer diatoms (Kulm, von Huene, et al., 1973; Reece et al., 2011). The Sequence II/III boundary was tentatively dated to $\sim 1$ Ma based on correlation with the upper Jaramillo (1r.1n) Subchronozone magnetic polarity reversal identified at Site 178 (Reece et al., 2011) (Fig. F2), making it coincident with the onset of Glacial Interval C of Berger et al. (2008a). Both sequence boundaries are synchronous with doubling of terrigenous sediment flux observed at Ocean Drill- ing Program (ODP) Site 887 at $\sim 6$ and $\sim 1 \mathrm{Ma}$ (Rea and Snoeckx, 1995), but no regional sequence boundary projected into Site 178 appears to correlate with the onset of Glacial Interval B (Reece et al., 2011) based on the ${ }^{40} \mathrm{Ar} /{ }^{39} \mathrm{Ar}$ ages of Hogan et al. (1978) (Fig. F2).

Key lithologies of interest as observed in Site 178 cores include tephras and other volcaniclastic detritus, variable amounts of ice-rafted debris, biosiliceous-rich intervals, turbidites, and general changes in depositional processes from prefan sedimentation to modern overbank deposition sourced from the Surveyor Channel, $\sim 60 \mathrm{~km}$ east of the site. Important contributions to hypothesis testing at this site will come from biostratigraphic and paleomagnetic age models, physical properties changes, and evolution in sedimentary facies in an increasingly glacially influenced setting.

\section{Operations Transit to Site U1417}

After a $1038 \mathrm{nmi}$ transit from Victoria, British Columbia (Canada), averaging $10.8 \mathrm{kt}$, the vessel arrived at Site U1417. The vessel stabilized over the site at $1101 \mathrm{~h}$ (UTC $-8 \mathrm{~h}$ ) on 4 June 2013 . The positioning beacon was deployed at $1121 \mathrm{~h}$ on 4 June and remained on the seafloor for the duration of the week. The position reference was a combination of GPS signals and a single acoustic beacon.

\section{Site U1417}

Site U1417 consists of five holes (Table T1), ranging in depth from 168.0 to $709.5 \mathrm{~m}$ drillers depth below seafloor (DSF) (Fig. F9). A total of 198 cores were recorded for the site. The interval cored with the advanced piston corer (APC) system was $836.5 \mathrm{~m}$, with $811.18 \mathrm{~m}$ recovered $(97 \%)$. The interval cored with the extended core barrel (XCB) system was $381.8 \mathrm{~m}$, with $140.77 \mathrm{~m}$ recovered $(36.9 \%)$. The interval cored with the rotary core barrel (RCB) system was 348.7 $\mathrm{m}$, with $146.92 \mathrm{~m}$ recovered $(42.1 \%)$. The overall recovery for Site U1417 was $70.1 \%$. Total time spent on Site U1417 was 18.6 days.

\section{Hole U1417A}

Hole U1417A was spudded at 0315 h on 5 June 2013. The seafloor was calculated to be $4198.6 \mathrm{~m}$ drillers depth below rig floor (DRF) (4187.7 meters below sea level). Nonmagnetic core barrels and the APC system were used for Cores 341-U1417A-1H through $20 \mathrm{H}$. Temperature measurements were taken with the advanced piston corer temperature tool (APCT-3) on Cores $4 \mathrm{H}, 10 \mathrm{H}$, and $13 \mathrm{H}$ with good results. APC cor- 
ing with the wireline continued through Core $22 \mathrm{H}$ with the half APC coring system using steel core barrels. Partial APC strokes were recorded on Cores $6 \mathrm{H}$, $8 \mathrm{H}, 18 \mathrm{H}, 19 \mathrm{H}, 20 \mathrm{H}$, and $21 \mathrm{H}$. The early incomplete strokes were likely due to an obstruction caused by large lonestones. Hole U1417A was terminated after Core $22 \mathrm{H}$ (168.0 m DSF). At the conclusion of coring, the top drive was set back and the drill string was pulled from the hole. The seafloor was cleared at $0935 \mathrm{~h}$ on 6 June, ending Hole U1417A. A total of 22 piston cores were taken over a $168.0 \mathrm{~m}$ interval, with $167.74 \mathrm{~m}$ recovered $(99.8 \%)$.

\section{Hole U1417B}

After clearing the seafloor, the vessel was offset $20 \mathrm{~m}$ east of Hole U1417A. Hole U1417B was spudded at $1225 \mathrm{~h}$ on 6 June 2013. Initially, orientation was planned, and the FlexIT tool was deployed. High heave conditions and mechanical shearing forced abandonment of core orientation measurements in Hole U1417B. Nonmagnetic core barrels and the APC system were used for Cores 341-U1417B-1H through $20 \mathrm{H}$. Cores $21 \mathrm{H}$ through $33 \mathrm{H}$ were cored using the half APC coring system. The XCB system was deployed for Cores 34X through 47X. Hole U1417B was terminated after Core 47X (358.8 m DSF). At the conclusion of coring, the top drive was set back and the drill string was pulled from the hole. The seafloor was cleared at $1645 \mathrm{~h}$ on 9 June, ending Hole U1417B. A total of 33 piston cores were taken over a $223.4 \mathrm{~m}$ interval, with $211.97 \mathrm{~m}$ recovered $(94.9 \%)$. A total of $14 \mathrm{XCB}$ cores were cut over a $135.4 \mathrm{~m}$ interval, with $50.99 \mathrm{~m}$ recovered $(37.7 \%)$. Total core recovery for Hole U1417B was $262.96 \mathrm{~m}$ for the 358.8 $\mathrm{m}$ cored interval $(73.3 \%)$.

\section{Hole U1417C}

After clearing the seafloor, the vessel was offset $20 \mathrm{~m}$ south of Hole U1417B. Hole U1417C was spudded at $1950 \mathrm{~h}$ on 9 June 2013, and the hole was washed down $1 \mathrm{~m}$ DSF. Orientation with the FlexIT tool was performed for Cores 341-U1417C-3H through 20H with satisfactory results. Nonmagnetic core barrels and the APC system were used for Cores $2 \mathrm{H}$ through $25 \mathrm{H}$. Cores $26 \mathrm{H}$ through $29 \mathrm{H}$ were cored using the half APC coring system. Hole U1417C was terminated after Core $29 \mathrm{H}$. The final depth of Hole U1417C was $226.0 \mathrm{~m}$ DSF. At the conclusion of coring, the top drive was set back and the drill string was pulled from the hole. The seafloor was cleared at $0725 \mathrm{~h}$ on 11 June, ending Hole U1417C. A total of 28 piston cores were taken over a $225.0 \mathrm{~m}$ interval, with $216.83 \mathrm{~m}$ recovered $(96.4 \%)$.

\section{Hole U1417D}

After clearing the seafloor, the vessel was offset $20 \mathrm{~m}$ west of Hole U1417C. Hole U1417D was spudded at $1155 \mathrm{~h}$ on 11 June 2013. Nonmagnetic core barrels and the APC system were used for Cores 341U1417D-1H through $18 \mathrm{H}$. After Core $18 \mathrm{H}$, the half APC coring system was deployed, and APC coring continued through Core $37 \mathrm{H}$. After Core $20 \mathrm{H}$, a 3.8 $\mathrm{m}$ interval was drilled. The XCB system was deployed starting with Core $38 \mathrm{X}$. Coring with the XCB system continued through Core $59 \mathrm{X}$, when the $\mathrm{XCB}$ cutting shoe returned to the surface without the cutting structure plus another 1 inch of the length of the shoe. Another XCB core barrel was dropped and was also damaged on recovery. The cutting shoe was then changed to a "softer sediment" type shoe, and coring continued. There was continuing evidence of an obstruction remaining in the hole, and after two more cutting shoe failures, coring was terminated after Core $65 \mathrm{X}$ at a final depth of $470.3 \mathrm{~m}$ DSF. The drill string was then pulled from the hole, and the bit cleared the rotary table at $1430 \mathrm{~h}$ on 16 June, ending Hole U1417D. A total of 36 piston cores were taken over a $220.1 \mathrm{~m}$ interval, with $214.64 \mathrm{~m}$ recovered $(97.5 \%)$. One drilled interval during the APC section of the hole was $3.8 \mathrm{~m}$ long. A total of $28 \mathrm{XCB}$ cores were cut over a $246.4 \mathrm{~m}$ interval, with $89.78 \mathrm{~m}$ recovered (36.4\%). Total core recovery for Hole $\mathrm{U} 1417 \mathrm{D}$ was $304.42 \mathrm{~m}$ for the $466.5 \mathrm{~m}$ cored interval (65.3\%).

\section{Hole U1417E}

After clearing the seafloor, the vessel was offset $20 \mathrm{~m}$ west of Hole U1417D. Hole U1417E was spudded at $0230 \mathrm{~h}$ on 17 June 2013, and the hole was drilled down to $264 \mathrm{~m}$ DSF. The wash barrel was then pulled, and Cores 341-U1417E-2R through 5R were cut to $302.2 \mathrm{~m}$ DSF. The wash barrel was again deployed, and the hole was advanced with a drilled interval to $399.0 \mathrm{~m}$ DSF. The wash barrel was pulled, and RCB coring with nonmagnetic RCB core barrels began with Core $7 \mathrm{R}$ and continued through Core $39 \mathrm{R}$ to a final depth of $709.5 \mathrm{~m}$ DSF. In total, 37 rotary cores were taken over a $348.7 \mathrm{~m}$ interval, with $146.92 \mathrm{~m}$ recovered $(42.1 \%)$. There were two drilled intervals in Hole U1417E that added up to $360.8 \mathrm{~m}$ of advance without recovery.

A total of $195 \mathrm{bbl}$ of high-viscosity mud was used during the drilling/coring process, and at the conclusion of the drilling/coring phase of Hole U1417E, an additional $50 \mathrm{bbl}$ sweep of high-viscosity mud was pumped to condition the hole for logging. After pumping the final sweep, the rotary shifting tool was 
deployed by wireline and the shifting sleeve inside the mechanical bit release was pulled, releasing the bit at the bottom of Hole U1417E. After releasing the bit, the sleeve was shifted back and the top drive was set back. The drill string was then tripped out of the hole, and the end of pipe was set at $81.4 \mathrm{~m}$ DSF for logging.

The triple combo tool string was then rigged up and run into the hole, reaching a total depth of $624.0 \mathrm{~m}$ wireline log depth below seafloor (WSF) at $0245 \mathrm{~h}$ on 21 June. The hole was then logged up, a short repeat pass was recorded, and the tools were pulled to the surface and rigged down. After rigging down the triple combo tool string, the Versatile Seismic Imager (VSI) tool string was rigged up. During the rig up time, the Protective Species Observation watches began, and it became immediately apparent that a small group of northern fur seals were present within the $940 \mathrm{~m}$ diameter exclusion zone for this site. The decision was made to terminate the VSI run for the day, pull back the VSI tool string, rig down, and prepare the Formation MicroScanner (FMS)-sonic tool string for deployment. The FMS-sonic tool string was then rigged up and deployed to $571.5 \mathrm{~m}$ WSF. Two full passes were made with the tool string, and it was then pulled to the surface and rigged down. The Magnetic Susceptibility Sonde (MSS) tool string was then rigged up and run; this run was the first deployment of the full MSS tool during the Integrated Ocean Drilling Program (IODP). The maximum depth the MSS tool string reached was $204.0 \mathrm{~m}$ WSF because of a constriction in the hole. This shallow part of the hole was then logged with two runs, and the tool string was pulled to the surface and rigged down. The VSI tool string was then rigged up and run into the hole. Protective Species Observation watches began at first light. No protected marine species were observed during this period within the exclusion zone, so the seismic source (a parallel cluster of two 250 inch $^{3}$ Sercel G. Guns) was ramped up starting $1 \mathrm{~h}$ after the watches commenced. Watches continued throughout the VSI run, with the guns fired manually as the tool string was run into the hole. The guns were powered down because of the presence of a whale during the manual firing stage. The whale entered the exclusion zone when the guns were powered down and then exited the exclusion zone. As the whale was observed to exit the zone within a short period of time, the guns were then ramped back up using a soft start procedure. Once the VSI tool string was in the hole, firing control was delivered to the Schlumberger engineer. After attempting to position the tool at the deepest possible depth and then moving it up to shallower stations, only one station was successfully completed at 211 m WSF, which consisted of two good shots. The tool string was pulled out of the hole to the surface and rigged down. The guns were secured, and the Protective Species Observation watches ceased. All logging equipment was rigged down by $1605 \mathrm{~h}$ on 22 June, and the knobbies were removed from the drill string. The drill string was then pulled from the hole.

\section{Lithostratigraphy}

Lithologic summaries of the five holes drilled at Site U1417 are shown in Figure F10. The sediment recovered at Site U1417 contains 17 facies. Detailed facies descriptions, information about common marine microfossils, facies occurrence in lithostratigraphic units, and tentative interpretations about depositional environments are summarized in Table T2. The dominant facies (F1a and F1b) are gray (N 4) to dark greenish gray (10Y 4/1) mud and account for $>90 \%$ of the core recovered. The remaining minor facies, although much less volumetrically significant, are distinctive and allow us to organize the cores into lithostratigraphic units. Photographs of the more common facies are shown in Figure F11. Based on characteristic facies associations, 5 major lithostratigraphic units and 12 subunits are defined (Table T3).

\section{Facies description}

Seventeen lithofacies were identified and are outlined in Table T2. The description of the facies for this site is based on the general lithofacies developed for all Expedition 341 sites. Lithofacies described at this site include massive mud with lonestones (F1a); massive mud without lonestones (F1b); silt (F2a); interbedded silt and mud (F2b); very fine to coarse sand (F3a); medium to coarse sand (F3b); interbedded sand and mud (F3c); muddy diamict (F4a); muddy and sandy diamict with lithic and mud clasts and/or terrigenous organic components (F4b); breccia (F4c); interbedded mud and diamict (F4d); diatom ooze (F5a); biosiliceous ooze (F5b); calcareous/ carbonate-bearing/rich mud, silt, sand, diamict, and/ or diatom ooze (F5c); volcanic ash (F6); volcaniclastic mud and sand (F7); and rock (F8). These facies reflect deposition from suspension fall out, sediment gravity flows, ice rafting, variations in organic productivity, volcanic eruptions, and eolian processes.

The lonestone-bearing, massive and bioturbated mud of Facies F1a is dark gray (N 4) to dark greenish gray (10Y 4/1) (Fig. F11A-F11B; Table T2). Color banding in this facies ranges from gray $(\mathrm{N} 4)$ to dark greenish gray (10Y 4/1), and individual bands range 
in thickness from 0.1 to $5 \mathrm{~cm}$. Bioturbation ranges from moderate to complete (for bioturbation scale, see "Lithostratigraphy" in the "Methods" chapter [Jaeger et al., 2014]). Based on smear slides, the composition of the mud is on average $90 \%$ clay size particles and $10 \%$ silt particles, with no apparent compositional differences between different color bands. Microfossil content is variable. Biosiliceous components are predominantly diatom microfossils, but minor amounts of sponge spicules and nannofossils are also documented. Lonestone clasts consist mainly of argillite and metasiltstone with secondary amounts of metabasalt and minor amounts of granite and sandstone (Fig. F12A-F12D). Facies F1b (Table T2) consists of greenish gray (10Y 5/1) to dark gray (N 4) mud without lonestones. Microfossil content is variable, as in Facies F1a. Zoophycos burrows are common in this facies, and relative to Facies F1a, color banding is not common. Petrographically, the composition of Facies F1b is similar to that of Facies F1a. In a minor number of beds in Facies F1b, diatoms, sponge spicules, and burrows have been pyritized (Fig. F12K).

Facies F2a and F3a (Table T2) consist of very thin to thin silt and sand beds (Fig. F11B) and are discussed together because of their common occurrence in the cores from Site U1417. These two facies range in color from dark gray (N 4) to greenish gray (5GY 5/1) and are mostly interbedded with the mud of Facies F1a and F1b. The silt and sand beds have sharp and sometimes erosional lower contacts with the underlying mud and primarily gradational upper contacts (Fig. F11B). Load casts occur along the bases of some beds in this facies (Fig. F12E). Individual bed thicknesses are $1-5 \mathrm{~cm}$, and normal grading is common. These facies are often well sorted and contain little fine-grained matrix. The grain composition of these two facies is almost entirely quartz and feldspar, with minor amounts of heavy minerals. Quartz in these facies is monocrystalline, and few lithic grains are documented. Less common are silt and sand beds rich in mafic components such as hornblende, biotite, and opaque minerals. The more mafic silt and sand beds are also enriched in heavy minerals relative to the more quartzofeldspathic sand and silt in this facies. In general, quartzofeldspathic sand and silt comprise $\sim 85 \%$ of the total sand and silt in these facies. Facies F2b consists of dark gray (N 4) to very dark gray (N 3) interbedded silt and mud. Lower contacts of silt laminae are most often sharp. Upper contacts are sharp or gradational. Bioturbation is none to slight.

Facies F3b (Table T2) consists of dark gray (N 4) to gray (N 5) medium to coarse sand and is distinguished from Facies F3a by its accessory components
(Fig. F11E). This facies often has a sharp lower contact and a gradational upper contact. Bed thickness is up to $40 \mathrm{~cm}$, but average bed thickness is $\sim 10-20 \mathrm{~cm}$. The sand has a very muddy matrix, and intraformational rip-up clasts are common (Fig. F11F). Coal clasts and woody detritus also occur in this facies (Figs. F11E, F12G-F12J). Based on smear slides, the composition of sand in Facies F3b is lithic rich with sedimentary (mainly mudstone and siltstone), volcanic, and metasedimentary (mainly argillite) grains. These sand beds also contain more mica than other sand facies at Site U1417. In smear slides, most mica appears to be biotite, but lighter colored micas are also identified in the visual core descriptions. Quartz in this facies is mainly monocrystalline, but polycrystalline quartz grains are also identified. Heavy minerals are a common minor constituent of Facies F3b. Facies F3b is gradational with the sandy diamict of Facies F4b. Facies F3c consists of interbedded sand and mud (Table T2). This facies is between 7 and 710 $\mathrm{cm}$ thick. Graded sand beds have sharp lower boundaries and sharp upper boundaries. Bioturbation is mostly absent in this facies.

Muddy diamict in Facies F4a (Table T2) is characterized by a dark gray (N 4) mud-rich matrix. Distinctive features of this facies are gradational lower contacts and sharp upper contacts defined by the relative clast concentration (Fig. F11C). Common clast sizes are granule and pebble, with clasts being subangular to subrounded. Based on smear slides, the composition of the sand fraction is primarily quartzofeldspathic. Facies F4b consists of muddy and sandy diamict with bed thickness up to $40 \mathrm{~cm}$ and containing predominantly mud clasts and/or organic components (Table T2; Fig. F11D). A sand and mud matrix with large outsized intraformational clasts characterizes this facies. Mud clasts can reach 3 $\mathrm{cm}$ in diameter. Other common clast types are coal and woody debris. These beds have sharp upper and lower contacts. Petrographically, this facies is characterized by more lithic grains in the sand fraction, similar to those described for Facies 3b, which occurs in close association with Facies F4b. Facies F4c consists of breccia with poorly organized clasts, and most of the clasts appear to be indurated diatom ooze. Internally, individual clasts contain evidence of soft-sediment deformation. Facies F4d consists of dark gray (N 4) interbedded mud and diamict (Table T2). Diamict beds often have gradational lower and sharp upper boundaries. Clasts within the diamict are up to $3 \mathrm{~cm}$ in diameter and are predominantly composed of mud clasts.

Facies F5a is characterized by dark gray (N 4) diatom ooze (Table T2; Fig. F11G-F11H). By definition, lithostratigraphic units with this facies contain $>50 \%$ diatoms (see "Lithostratigraphy" in the "Methods" 
chapter [Jaeger et al., 2014]). The remaining constituents in this facies are typically mud, and in some cases calcareous mud is documented. Contacts vary between gradational and sharp. Bed thickness for Facies F5 varies from 20 to $150 \mathrm{~cm}$. Bioturbation is common in this facies, including Zoophycos burrows (Fig. F11G-F11H).

Facies F6 is defined by gray (5Y 4/1) to brown (5YR $5 / 3$ ) volcanic ash (Fig. F13). Bed contacts range from sharp to gradational. Compositionally, this facies consists of $80 \%$ glass shards (vitric fragments). The remaining framework grains are feldspar, quartz, and opaque minerals. Dark gray (N 4) volcaniclastic mud and sand define Facies 7 (Fig. F13E-F13F). Bed thickness ranges from 1 to $5 \mathrm{~cm}$. These beds consist of a mixture of volcanic glass (typically 10\%-20\%), quartz, feldspar, and often diatom microfossils. Beds are often bioturbated.

Facies 8 consists of dark gray (N 4) lithified siltstone with abundant calcite cement. These beds occur sporadically and are often associated with poor core recovery.

\section{Lithostratigraphic units}

Based on facies associations, five major lithostratigraphic units (I-V) are defined (Table T3; Fig. F10). Units I and $\mathrm{V}$ are further divided into subunits. The contacts between lithostratigraphic units at Site U1417 are usually gradational, and the criteria used to define units are discussed below.

\section{Unit I}

\section{Subunit IA}

Intervals: $341-\mathrm{U} 1417 \mathrm{~A}-1 \mathrm{H}-1,0 \mathrm{~cm}$, to $11 \mathrm{H}-2,18$ $\mathrm{cm} ; 341-\mathrm{U} 1417 \mathrm{~B}-1 \mathrm{H}-1,0 \mathrm{~cm}$, to $10 \mathrm{H}-2,131 \mathrm{~cm}$; $341-\mathrm{U} 1417 \mathrm{C}-2 \mathrm{H}-1,0 \mathrm{~cm}$, to $10 \mathrm{H}-2,48 \mathrm{~cm} ; 341-$ $\mathrm{U} 1417 \mathrm{D}-1 \mathrm{H}-1,0 \mathrm{~cm}$, to $10 \mathrm{H}-3,38 \mathrm{~cm}$

Depths: Hole U1417A $=0-77 \mathrm{~m}$ core depth below seafloor (CSF-A); Hole U1417B = 0-79.4 m CSFA; Hole U1417C = 0-77 m CSF-A; Hole U1417D $=0-78.8 \mathrm{~m}$ CSF-A

Age: Middle Pleistocene to Holocene

Subunit IA contains dark gray (N 4) mud (Fig. F11A) with subordinate interbeds of volcanic ash as thick as $4 \mathrm{~cm}$ (Table T3; Fig. F13A-F13C). Dispersed granule- to pebble-sized lonestones (outsized clasts) are common. Lonestone clasts consist mainly of argillite and metasiltstone, with secondary amounts of metabasalt and minor amounts of granite and sandstone (Fig. F12A-F12D). Greenish gray (10Y 5/1) intervals of diatom-bearing mud with approximately five diatom ooze layers between 20 and $40 \mathrm{~cm}$ thick alternate with barren gray (N 5) mud. Volcanic ash con- sists of $>80 \%$ vitric (glass) framework grains (Fig. F13). Although volcanic ash ( $>90 \%$ primary volcanic grains; see "Lithostratigraphy" in the "Methods" chapter [Jaeger et al., 2014]) comprises $<1 \%$ of the total described lithology of this subunit, it is considered important. The relative volcanic grain abundance is plotted on the summary diagrams for each hole for reference (Fig. F10).

\section{Subunit IB}

Intervals: $341-\mathrm{U} 1417 \mathrm{~A}-11 \mathrm{H}-2,18 \mathrm{~cm}$, to $22 \mathrm{H}-\mathrm{CC}$, $38 \mathrm{~cm} ; 341-\mathrm{U} 1417 \mathrm{~B}-10 \mathrm{H}-2,131 \mathrm{~cm}$, to $17 \mathrm{H}-\mathrm{CC}$, $17 \mathrm{~cm}$; 341-U1417C-10H-2, $48 \mathrm{~cm}$, to $18 \mathrm{H}-3,18$ $\mathrm{cm}$; 341-U1417D-10H-3, $38 \mathrm{~cm}$, to $22 \mathrm{H}-1,0 \mathrm{~cm}$

Depths: Hole U1417A = 77-168 m CSF-A (bottom of hole); Hole U1417B = 79.4-151.9 m CSF-A; Hole U1417C = 77-154.1 m CSF-A; Hole $\mathrm{U} 1417 \mathrm{D}=78.8-166.3 \mathrm{~m}$ CSF-A

Age: early to Middle Pleistocene

This subunit shares all lithologic characteristics with Subunit IA; however, it also includes intervals of diatom ooze that occur frequently, with as many as five intervals per core (Table T3; Fig. F11G-F11H). Ooze intervals are generally $<10 \mathrm{~cm}$ thick. Dispersed granule- to pebble-sized lonestones are more common than in Subunit IA. Silt and sand beds are $2-4 \mathrm{~cm}$ thick (Fig. F11B). Volcanic ash ( $>90 \%$ primary volcanic grains; see "Lithostratigraphy" in the "Methods" chapter [Jaeger et al., 2014]) represents $<1 \%$ of the total described lithology of this subunit and consists of $>80 \%$ vitric (glass) framework grains.

\section{Unit II}

Intervals: $341-\mathrm{U} 1417 \mathrm{~B}-17 \mathrm{H}-\mathrm{CC}, 17 \mathrm{~cm}$, to $37 \mathrm{X}-\mathrm{CC}$, $30.5 \mathrm{~cm}$; $341-\mathrm{U} 1417 \mathrm{C}-18 \mathrm{H}-3,18 \mathrm{~cm}$, to $29 \mathrm{H}-$ CC, $7 \mathrm{~cm}$; 341-U1417D-22H-1, $0 \mathrm{~cm}$, to $42 \mathrm{X}-1$, $85 \mathrm{~cm}$

Depths: Hole U1417B $=151.9-256.2$ m CSF-A; Hole U1417C $=154.1-226$ m CSF-A (bottom of hole); Hole U1417D = 166.3-263.5 m CSF-A

Age: early Pleistocene

This unit is identified by distinct $1-5 \mathrm{~cm}$ thick interbeds of fine sand and coarse silt in dark gray ( $\mathrm{N} 4)$ to greenish gray (10Y 5/1) mud. Mud beds are massive to normally graded and commonly have sharp lower contacts (Table T3). Sand/silt beds occur in the mud at irregularly spaced intervals ranging from 5 to 15 $\mathrm{cm}$. Relative to Unit I, this unit contains fewer lonestones; however, they occur throughout the unit and range up to as many as eight clasts per section. Volcanic ash beds are present, with eight beds distributed over Unit II. Diatom-rich intervals, including thin beds of ooze, similar to those in Unit I occur near the top of Unit II. 


\section{Unit III}

Intervals: $341-\mathrm{U} 1417 \mathrm{~B}-38 \mathrm{X}-1,0 \mathrm{~cm}$, to $41 \mathrm{X}-1,40$ $\mathrm{cm}$; 341-U1417D-42X-1, $85 \mathrm{~cm}$, to $46 \mathrm{X}-1,92$ $\mathrm{cm}$; 341-U1417E-2R-1, $7.5 \mathrm{~cm}$, to 5R-CC, $10 \mathrm{~cm}$

Depths: Hole U1417B $=256.2-291.3 \mathrm{~m}$ CSF-A; Hole U1417D $=263.5-296.6 \mathrm{~m}$ CSF-A; Hole $\mathrm{U} 1417 \mathrm{E}=264.1-297.3 \mathrm{~m}$ CSF-A

Age: early Pleistocene

This unit is bounded by the first and last occurrences of $4-8 \mathrm{~cm}$ thick beds of muddy diamict interbedded with intervals of bioturbated dark gray (N 4) mud up to $40 \mathrm{~cm}$ thick (Table T3; Fig. F11C). Core disturbance makes this relationship difficult to observe in many cases. Diamict intervals contain gravel-sized subangular to subrounded clasts in a muddy matrix and have gradational lower contacts and typically sharp upper contacts. Clast abundance increases uphole in individual beds. Common clast types include argillite and metasiltstone, with secondary amounts of metabasalt.

\section{Unit IV}

Intervals: $341-\mathrm{U} 1417 \mathrm{~B}-41 \mathrm{X}-1,40 \mathrm{~cm}$, to $47 \mathrm{X}-\mathrm{CC}$, $26 \mathrm{~cm}$; 341-U1417D-46X-1, $92 \mathrm{~cm}$, to 50X-1, 63 $\mathrm{cm}$

Depths: Hole U1417B = 291.3-350.0 m CSF-A (bottom of hole); Hole U1417D $=296.6-335.1 \mathrm{~m}$ CSF-A

Age: late Pliocene

Unit IV contains dark gray ( $\mathrm{N} 4$ ) to dark greenish gray (5GY 4/1) clay-rich mud that is commonly highly bioturbated. Zoophycos burrows and diatombearing intervals as thick as $140 \mathrm{~cm}$ are common (Fig. F11G). Lonestones are absent.

\section{Unit V}

Intervals:

VA: 341-U1417D-50X-1, $63 \mathrm{~cm}$, to 56X-CC, 19 $\mathrm{cm}$;

VB: 341-U1417D-56X-CC, $19 \mathrm{~cm}$, to 60X-CC, 10 $\mathrm{cm}$; 341-U1417E-7R-1, $0 \mathrm{~cm}$, to 10R-3, $0 \mathrm{~cm}$;

VC: 341-U1417D-60X-CC, $10 \mathrm{~cm}$, to $65 \mathrm{X}-\mathrm{CC}$, $21 \mathrm{~cm}$; 341-U1417E-10R-3, $0 \mathrm{~cm}$, to 15R-1, 66 $\mathrm{cm}$;

VD: 341-U1417E-15R-1, $66 \mathrm{~cm}$, to 15R-6, $55 \mathrm{~cm}$;

VE: 341-U1417E-15R-6, $55 \mathrm{~cm}$, to 29R-3, $11 \mathrm{~cm}$;

VF: 341-U1417E-29R-3, $11 \mathrm{~cm}$, to 29R-CC, 17 $\mathrm{cm}$;

VG: 341-U1417E-29R-CC, $17 \mathrm{~cm}$, to 32R-2, 0 $\mathrm{cm}$;

VH: 341-U1417E-32R-2, $0 \mathrm{~cm}$, to 35R-1, $53 \mathrm{~cm}$; VI: 341-U1417E-35R-2, $0 \mathrm{~cm}$, to $39 \mathrm{R}-6,13 \mathrm{~cm}$; VJ: 341-U1417E-39R-6, $13 \mathrm{~cm}$, to 39R-CC, $23 \mathrm{~cm}$
Depths:

VA: Hole U1417D = 335.1-394.3 m CSF-A;

VB: Hole U1417D = 394.3-432.0 m CSF-A, Hole U1417E = 399.0-431.0 m CSF-A;

VC: Hole U1417D = 432.0-461.5 m CSF-A (bottom of hole), Hole U1417E $=431.0-477.7 \mathrm{~m}$ CSF-A;

VD: Hole U1417E = 477.7-484.6 m CSF-A;

VE: Hole U1417E $=484.6-615.4 \mathrm{~m}$ CSF-A;

VF: Hole U1417E $=615.4-619.0 \mathrm{~m}$ CSF-A;

VG: Hole U1417E $=619.0-642.8 \mathrm{~m}$ CSF-A;

VH: Hole U1417E $=642.8-661.5 \mathrm{~m}$ CSF-A;

VI: Hole U1417E $=661.5-705.9 \mathrm{~m}$ CSF-A;

VJ: Hole U1417E $=705.9-708$ m CSF-A (bottom of hole)

Age: Miocene to Pliocene

Unit V contains predominantly dark gray (N 4) mud with subordinate muddy and sandy diamict, interbedded silt/mud and sand/mud, and diatom ooze (Table T3). Because Unit V is highly diverse, it is divided into 10 subunits to differentiate biosiliceousrich (diatom ooze) intervals from intervals dominated by terrigenous sediment flux (Fig. F10E). Subunits VA, VC, VE, VG, and VI consist mainly of dark gray (N 4) mud, sandy diamict with lithic and mud clasts up to $3 \mathrm{~cm}$ diameter, and plant fragments (Fig. F11D); massive and graded sand beds (Fig. F11EF11F); interbedded silt and mud; and occasional diatom-rich intervals and diatom ooze. The top of Subunit VA is defined by the first occurrence of a $50 \mathrm{~cm}$ thick very dark gray (5Y 3/1) sand bed underlain by a sandy diamict bed. Within the subunit, three other sand beds and six other diamict intervals are interbedded with biosiliceous-bearing mud or diatom ooze. The diamict beds contain lithic and mud clasts, as well as plant fragments. Subunit VC has similar characteristics, with mud clasts and coal in the diamict beds. Subunit VE is defined by diamict containing coal clasts interbedded with dark greenish gray (10Y 4/1) interbedded silt and mud. Subunit VG is defined by the occurrence of normally graded sandy mud beds ranging in thickness from 10 to 60 $\mathrm{cm}$ interbedded with mud. These sand beds include mud clasts and granules of coal. Subunit VI is interbedded similarly to Subunit VG, except that the intervals of muddy silt are as thick as $180 \mathrm{~cm}$. Finegrained Subunits VB, VD, VF, VH, and VJ consist mainly of dark gray (N 4) mud with diatom-rich intervals and diatom ooze, the latter occasionally exceeding $150 \mathrm{~cm}$ in thickness. Color banding also can be a characteristic feature of these subunits (Fig. F11H). Of these, Subunit VF is most notable because it includes a breccia bed that is $80 \mathrm{~cm}$ thick. In Unit $\mathrm{V}$, ash (Fig. F13) and extensional deformation structures (Fig. F12F) are observed occasionally. Plant de- 
bris and terrestrial organic detritus (coal) are components of the sandy diamict (Figs. F11E, F12G-F12J).

\section{Petrography}

\section{Clast lithologies}

The main lithologies of the diamict clasts and lonestones contained in Site U1417 sediment are of lowgrade metamorphic origin. In decreasing order of abundance, the lithologies are argillite, metasiltstone, and basalt. Sandstone, siltstone, granite, and quartzite are minor lithologies. These lithologies are unevenly distributed between Holes U1417AU1417E. The average clast ratio for Site U1417, based on the main lithology types metamorphic (M), sedimentary (S), and igneous (I), is $\mathrm{M}_{73} \mathrm{~S}_{15} \mathrm{I}_{12}$.

\section{Bulk mineralogy}

X-ray diffraction (XRD) analyses were performed on 131 powdered bulk samples from Holes U1417AU1417E to delineate the bulk mineralogy and identify compositional trends with age or depth in the cores. Diffraction patterns are shown in Figure F14, and the relative mineral diffraction peak intensities, as defined in "Lithostratigraphy" in the "Methods" chapter (Jaeger et al., 2014), are listed in Table T4. In general, the mineralogy is uniform downhole, although there are some variations in relative peak intensities, which may indicate slight variations in mineral content. Figure F14A shows the scans for 14 representative samples from this site. The primary minerals identified include quartz, plagioclase (feldspar), mica (muscovite/illite and biotite), and the minerals chlorite and/or kaolinite. Quartz and plagioclase are the dominant peaks, with quartz generally the larger. Figure F14B shows the comparative XRD patterns from $4^{\circ}$ to $24^{\circ} 2 \theta$, where scans run before and after the samples underwent a glycol treatment (see "Lithostratigraphy" in the "Methods" chapter [Jaeger et al., 2014]). This treatment was used to determine the presence of expandable clay minerals (e.g., smectite). The scans show no indication of expandable clay minerals until $\sim 100 \mathrm{~m}$ core composite depth below seafloor (CCSF-B) in the cores. From this depth downhole, we observe a shoulder at $\sim 7^{\circ} 2 \theta$ in the samples. After the treatment, a small but distinct peak is observed at $\sim 5^{\circ} 2 \theta$, suggesting the presence of expandable clay minerals. Additional minor mineralogical phases documented in the bulk mineralogy of the cores include calcite associated with well-indurated siltstone intervals and pyrite associated with localized structures such as burrows (Fig. F12K). These phases are most common in lithostratigraphic Unit V. Our preliminary findings are similar to the results of Molnia and Hein (1982) from sam- ples collected on the continental shelf of the Gulf of Alaska.

\section{Physical properties characteristics of selected lithologies}

We integrated physical properties data measured using the onboard core logging systems with our sediment core and smear slide descriptions in an attempt to establish relationships that could be used to map the distribution of selected sedimentary attributes and facies at a higher resolution. Sand, volcanic ash, diatom ooze, lonestones, and diamict beds exhibit somewhat unique variations in magnetic susceptibility, bulk density, natural gamma radiation (NGR), $P$ wave velocity, and color reflectance that can be used to highlight and predict downcore distribution of lithologic features. Because dark gray (N 4) mud is the dominant lithology observed at Site U1417, the physical properties data provided a relatively fast method to identify variations in lithology and identify potential intervals of interest for further study.

Figure F15 provides an example of this comparative technique where downcore variations in magnetic susceptibility, bulk density, NGR, and color reflectance are compared to sediment lithology seen in core imagery and smear slide photomicrographs across the lithostratigraphic Subunit IB-Unit II transition in Hole U1417C. Units of diatom ooze centered at 146.6, 147.25, and $148 \mathrm{~m}$ CSF-A are lighter gray in core imagery and correspond with relatively low magnetic susceptibility, gamma ray attenuation (GRA) bulk density, and NGR values and relatively high reflectance index values. We use a color reflectance index calculated from the absolute value of $\mathrm{a}^{*}$ / $\mathrm{b}^{*}$, which appears to capture the contrast in sediment color across the transitions between mud and ash, ooze, and sand/silt beds. A volcanic ash bed and mafic-rich sand centered between 146.25 and 146.5 $\mathrm{m}$ CSF-A result in a complex physical properties data response with respect to magnetic susceptibility. The divergence can be attributed to the difference in mineralogy between the two beds, where the maficrich sand has elevated magnetic susceptibility. An interval of interbedded sand and mud centered at $149.8 \mathrm{~m}$ CSF-A is well defined by higher magnetic susceptibility and higher color reflectance index values, which mirror the magnetic mineral content of the sand and the change in color across the sand beds, respectively.

\section{Lithostratigraphy and depositional environments}

Major characteristics that define the lithostratigraphic units for Site U1417 are summarized in Figure F16. 


\section{Unit I}

Lithostratigraphic Subunits IA and IB consist mainly of dark gray ( $\mathrm{N} 4)$ mud with lonestones and recurring intervals of diatom ooze in Subunit IB (Tables T2, T3). Lonestones are interpreted to be ice-rafted debris deposited from icebergs. The presence of lonestones thus seems to be evidence for tidewater glaciation. Our interpretation is that most of the mud in Unit I originated from suspension settling through the water column and from sediment gravity flows reaching the distal portions of the Surveyor Fan (Powell and Molnia, 1989). Sediment reworking and deposition could also be related to temporal variations in bottom current strength and direction. Recurring intervals of diatom ooze in Subunit IB might be related to one or several of the following processes:

- Increased biological productivity in the water column in the vicinity of sea ice margins (Sakshaug, 2004; Smith et al., 1987);

- Increased biological productivity due to optimized oceanographic conditions (e.g., reduced sea ice cover, surface layer overturning, and/or mixing by gyres);

- Enhanced macro (N or P) and/or micro (Fe) nutrient supply from land (volcanic ash, dust, etc.), leading to increased biological productivity (Hamme et al., 2010; Davies et al., 2011; Addison et al., 2012);

- Seawater silica saturation, leading to higher diatom productivity and preservation (e.g., Brzezinski et al., 1998; Dugdale et al., 1995); and/or

- Decreased input of terrigenous sediments (i.e., less dilution).

The source for some of the sediment represented by Unit I is interpreted to be the onshore St. Elias and Chugach Mountains located along the southern coast of Alaska. The dominance of low-grade metamorphic lithologies in the lonestones suggests that the Chugach Metamorphic Complex (Gasser et al., 2011) may have been a primary ice-rafted debris source during deposition of both Subunits IA and IB. The fairly even distribution of volcanic ash and volcaniclastic-bearing sand indicates that the location was proximal enough to either the Aleutian or Wrangell volcanic belts to have periodic influxes of pyroclastic detritus.

\section{Unit II}

We infer that sedimentary processes in Unit II were generally similar to depositional processes in Unit I (i.e., that sediment supply mainly occurred from suspension fallout, sediment gravity flows, and ice- bergs). However, the increased number of thin beds of fine sand and coarse silt suggests more frequent and more regular deposition from sediment gravity flows (e.g., low-density turbidity flows) (Lowe, 1982) on the distal Surveyor Fan. In addition, the relative absence of diatom ooze intervals may reflect reduced productivity in the water column. This reduced productivity might be caused by one or several factors, including (1) increased sea ice coverage or a larger distance to the sea ice edge, (2) limited nutrient supply, (3) secondary diagenetic processes (such as the dissolution of silica), and/or (4) increased dilution of biogenic-rich intervals by terrigenous sediment.

\section{Unit III}

Unit III is characterized by muddy diamict interbedded with bioturbated dark gray (N 4) mud. As in Units I and II, our interpretation is that the muddy sediment was deposited from suspension, as well as from distal sediment gravity flows and icebergs. The lonestones in Unit III are the oldest observed in the sedimentary record at Site U1417 (early Pleistocene or late Pliocene), and they reflect the first appearance at this site of iceberg-derived sediment from calving of tidewater glaciers into the Gulf of Alaska. The accumulation of clasts that form diamict intervals in Unit III in Holes U1417B, U1417D, and U1417E potentially record periods of significantly enhanced ice rafting and/or reduced deposition of mud. Whereas the gradational lower boundaries of the diamict beds most probably mirror a gradual increase in ice rafting, an abrupt termination in ice rafting may have led to the formation of a sharp upper boundary and the onset of "nonglacial" conditions as indicated by the deposition of mud and enhanced bioturbation. The repeated occurrence of couplets of muddy diamict and mud may reflect (1) the recovery of deposits from multiple glacial and interglacial cycles, (2) temporarily increased ice rafting due to enhanced calving from the glacier margin, or (3) dumping from icebergs. Because the pattern of gradual onset and abrupt termination of ice rafting is very similar to "typical" glacial-interglacial cycles, we suggest that the deposits may archive large-scale climatic changes. Further refinement of the shipboard age model may be necessary to confirm this.

\section{Unit IV}

The main characteristics of Unit IV are intense bioturbation and diatom-bearing intervals, the absence of lonestones, and the presence of isolated fine sand beds. The more intense bioturbation is suggestive of limited terrigeneous sediment influx and/or more productive water column conditions. 


\section{Unit V}

Unit $\mathrm{V}$ is divided into subunits to distinguish periods of reduced terrigenous sediment supply and higher biological productivity and/or better preservation (diatom ooze; Subunits VB, VD, VF, VH, and VJ) from periods of higher flux of terrigenous sediment (mud; Subunits VA, VC, VE, VG, and VI). Both periods are interrupted by muddy and sandy diamict deposition. The diamict is interpreted to be deposited from sedimentary gravity flows (e.g., high-density turbidity flow) (Lowe, 1982). A distinctive characteristic of Unit $\mathrm{V}$ is the presence of coal clasts and woody plant detritus in the sandy diamict facies (Figs. F11E, F12IF12J). These components are tentatively interpreted to be derived from the coal-bearing Eocene Kulthieth Formation exposed in the onshore thrust belt in the St. Elias and Chugach Mountains (e.g., Plafker, 1987). Other unique characteristics of Unit V are small normal faults (commonly $<2 \mathrm{~cm}$ of displacement) in the lower parts of Hole U1417E (Fig. F12F). These faults may be related to deformation along the outer rise of the Pacific plate due to subduction at the Aleutian Trench west of Site U1417. Many active normal faults have been mapped in this portion of the Pacific plate and are related to plate-bending processes (Reece et al., 2013).

The provenance of the sediment documented in Unit V is unclear. A southeastward restoration of the position of the Pacific plate (i.e., accounting for current northwest plate vectors) may show that these submarine fan systems were supplied with sediment from the coastal mountains of the Yukon Territory and northwestern British Columbia (e.g., the Coast Plutonic Complex). However, more detailed provenance studies are required to verify the locations of onshore sources of sediment for Unit V.

\section{Paleontology and biostratigraphy}

Samples from Site U1417 reveal rich assemblages of siliceous microfossils, whereas calcareous microfossils are less abundant in most intervals. Diatoms and radiolarians are abundant to rare and well to poorly preserved in several intervals. These diatom and radiolarian assemblages permit the establishment of biostratigraphic schemes, which are complemented by planktonic foraminifers (Fig. F17; Table T5). Changes in the preservational quality and abundance of siliceous microfossils and in the diagenetic alteration of calcareous microfossils appear to correlate with changes in pore water chemistry (silica concentrations and magnesium, calcium, and alkalinity concentrations, respectively; see "Geochemistry"). According to our biostratigraphic datums, summarized in Table $\mathbf{T} 5$, the deepest recovered sediments from Site U1417 are 10 Ma. Beyond the biostratigraphic schemes, the micropaleontologic assemblages provide insight into paleoclimatologic and paleoceanographic conditions of the subarctic northeast Pacific Ocean. In particular, the relative abundances of certain diatoms, radiolarians, and planktonic foraminifers suggest climatic variations between warm and cool intervals (Figs. F18, F19). Elements of the benthic foraminiferal fauna and diatom flora also suggest the transport of biogenic material from shallower water environments (Fig. F19).

\section{Diatoms}

We investigated core catcher samples and sediment from selected split core sections from Holes U1417AU1417E to define the sediment age and paleoenvironmental conditions (Tables T5, T6). For a detailed description of diatom zonal scheme and taxonomy, see "Paleontology and biostratigraphy" in the "Methods" chapter (Jaeger et al., 2014).

\section{Diatom biostratigraphy}

A total of 464 slides, which include samples from the core catcher and split core sections, were prepared for diatom analyses from Holes U1417A-U1417E (Table T6). Eight diatom datums were observed at Site U1417 (Table T5). Diatoms associated with North Pacific Diatom Zones 6B-12 were present (late Miocene-Pleistocene).

\section{Diatom paleoenvironmental considerations}

Valve abundance and preservation varies strongly throughout the sediment column (Figs. F17). High to moderate abundances are mostly recorded in the upper $\sim 200 \mathrm{~m}$ CCSF-B and between $\sim 300$ and $\sim 420$ $m$ CCSF-B (Fig. F19). Except for a few samples, the intervals from 245 to 300 and 440 to $800 \mathrm{~m}$ CCSF-B are barren of diatoms. In general, valve preservation closely matches the total diatom abundance and tends to be good when abundance is high. Variations in preservation and abundance and shifts in the assemblage possibly reflect past paleoceanographic changes in the pelagic and the coastal regions of the Gulf of Alaska.

The Site U1417 diatom community mostly consists of Pliocene and Pleistocene species, typical of cold waters of the high-latitude northeastern and subarctic Pacific Ocean. The well-preserved, cold-to-temperate water species Neodenticula seminae (Simonsen et Kanaya) Akiba et Yanagisawa is common in the uppermost 200-225 m CCSF-B (Table T6; Fig. F18). In present-day observations, periods of high relative abundances of $N$. seminae correspond to periods of 
high opal and organic carbon fluxes in the northeast Pacific (Takahashi et al., 1990). Based on her survey of the diatom community preserved in surface (Holocene) sediments of the Bering and Okhotsk Seas, Sancetta (1982) concluded that N. seminae is a good tracer of the main path of the Alaska Current and a good indicator of the variability of paleohydrographic and paleoclimatic conditions in the Gulf of Alaska. However, because not all diatom valves are equally affected by dissolution, its downcore record should be cautiously interpreted.

The composition of the cold-water species diatom assemblage differs between the uppermost $\sim 200 \mathrm{~m}$ and the interval from $\sim 300$ to $435 \mathrm{~m}$ CCSF-B. A major downhole shift toward a relative increase of Coscinodiscus marginatus, a decrease of Actynocyclus curvatulus, and the disappearance of $N$. seminae occurs in the cold-water assemblage around $\sim 225 \mathrm{~m}$ CCSFB (Table T6; Fig. F18). This shift may be associated with the intensification of Northern Hemisphere glaciation after 2.6-3 Ma and the development of the modern halocline system in the subarctic Pacific (Swann et al., 2006). Because C. marginatus is apparently well adapted to present-day high nutrient supply during short periods of low-incident radiation (Takahashi et al., 1990), its higher relative contribution between $\sim 300$ and $470 \mathrm{~m}$ CCSF-B at Site U1417 can be interpreted as reflecting enhanced productivity during periods of reduced solar radiation. According to the diatom flux study of Takahashi et al. (1990), the well-silicified centric diatom A. curvatulus peaks during modern spring flux maxima in the northeast Pacific. During the late Quaternary, it had its highest relative contribution during glacials in the Bering Sea (Katsuki and Takahashi, 2005).

Other cold-water species present at Site U1417 are Actinocyclus ochotensis Jousé, Asteromphalus robustus Castracane, Bacteriosira fragilis (Gran) Gran, Rhizosolenia hebetata f. hiemalis J.W. Bailey, Shionodiscus trifultus, Thalassiosira gravida Cleve, and Thalassiosira hyalina (Grunow in Cleve et Grunow) Gran (Sancetta, 1982; Medlin and Priddle, 1990; Koizumi 2008). Their occurrences are sporadic, and they have low abundances at Site U1417 (Table T6). Warm-water species Rhizosolenia hebetata f. semispina (Hensen) Gran, Shionodiscus oestrupii (G. Fryxell) A.J. Alverson et al., and Thalassiosira leptopus (Grunow in Van Heurck) Hasle et G. Fryxell (Koizumi, 2008) are rare components of the Site U1417 assemblage. Temperate-water species Thalassiothrix spp. and Stephanopyxis spp. (Hasle and Syvertsen, 1996) are sporadically recorded.

Rare occurrences of Achnanthes spp., Cocconeis spp., Grammatophora spp., Rhabdonema spp., and Paralia sulcata (Ehrenberg) Cleve at Site U1417 also point to a certain degree of downslope transport from the Alaskan coast into the deeper pelagic waters overlying Site U1417. In addition, the sporadic occurrences of several freshwater/neritic marine species (e.g., Achnanthes lanceolata [Brébisson ex Kützing] Grünow and Cyclotella spp.) (Table T6) may reflect periods of enhanced terrigenous input into the pelagic realm of the Gulf of Alaska. Similarly, the recurrent presence of resting spores of Chaetoceros in the uppermost $\sim 250 \mathrm{~m}$ CCSF-B (Fig. F19) is indicative of downslope transport into deeper waters of the Gulf of Alaska.

A striking feature of the sediments from Site U1417 is the occurrence of interbedded diatom-rich sediments suggestive of diatom ooze (See "Lithostratigraphy"). These diatom-rich sediments between $\sim 20$ and $180 \mathrm{~m}$ CCSF-B and between $\sim 360$ and $430 \mathrm{~m}$ CCSF-B are primarily composed of $N$. seminae, Thalassiothrix spp., and Coscinodiscus spp. and alternate with mixed sediments (Fig. F16).

\section{Radiolarians}

A total of 196 samples in Holes U1417A-U1417E were prepared for radiolarian analyses. Radiolarians are abundant in the upper part of Site U1417 (Fig. F17). However, for depths below $210 \mathrm{~m}$ CCSF-B, the occurrence of radiolarians is sporadic and abundances are low. The preservation of radiolarians is good to poor in the upper $\sim 200 \mathrm{~m}$ CSF-A and decreases to poor at greater depths. Fluctuations in species abundance are presented in Table T7.

\section{Radiolarian biostratigraphy}

Nine radiolarian datums are present at Site U1417; they indicate sediment ages from late Miocene to present (Table T5; see Fig. F10 in the "Methods" chapter [Jaeger et al., 2014]).

\section{Radiolarian paleoenvironmental considerations}

The paleoenvironmental conditions at Site U1417 are inferred by using key radiolarian species grouped according to their common ecological responses to environmental control factors (sea-surface temperature and salinity). These groups are based on multivariate cluster and factor analyses of radiolarians preserved in surface sediment from the North Pacific (Kamikuri et al., 2008) and the Central Indian Ocean (Gupta, 1996), in the sediment traps of the Indian Ocean (Gupta et al., 2002), in the modern radiolarian mapping of the world oceans (Boltovskoy et al., 2010), and from late Miocene sediments (Gupta and Srinivasan, 1992). Cycladophora davisiana and Spongopyle osculosa are grouped as cold deepwater species $(>200 \mathrm{~m})$, whereas Ceratospyris borealis, Actinomma 
boreale, Stylodictya validispina, and Larcopyle buestchlii are cold-water species living in the upper $\sim 200 \mathrm{~m}$ of the water column. The subarctic-temperate group is composed of Lithelius minor and Larcopyle weddelium. Cold-water radiolarians (both deepwater and surface species) have higher relative abundances in the upper $\sim 225 \mathrm{~m}$ CCSF-B of the sediment record, whereas between $\sim 300$ and $400 \mathrm{~m}$ CCSF-B, temperate species increase in relative abundance (Fig. F18).

\section{Foraminifers}

Core catcher samples from Holes U1417A-U1417D were examined for planktonic foraminifers from the $>125 \mu \mathrm{m}$ size fraction in 85 samples (Table T8) and for benthic foraminifers from the $>63 \mu \mathrm{m}$ size fraction in 105 samples (Table T9). Samples from Hole U1417E would not disaggregate and were not investigated. Most core catcher samples were dominated by siliciclastic material in the $>63 \mu \mathrm{m}$ size fraction, although a few samples were dominated by diatoms or had very little sand-sized material.

\section{Planktonic foraminifers}

Sixteen planktonic foraminifer species were encountered in Holes U1417A-U1417D (Table T8). Assemblages are composed of subarctic to temperate water species, dominated by Neogloboquadrina pachyderma. Preservation varies from poor to good, generally decreasing in quality with depth (Fig. F17). Furthermore, the high number of barren samples (40 of 89 samples) suggests diagenetic dissolution of foraminifer shells in the sediments.

The lack of a continuous planktonic foraminiferal record because of poor preservation at Site U1417 makes it difficult to determine precise biozones. At Site U1417, the last occurrence (LO) of Neogloboquadrina inglei ( $0.7 \pm 0.1 \mathrm{Ma})$ (Kucera and Kennett, 2000) is recognized (Table T5). Neogloboquadrina kagaensis (LO $1.9 \pm 0.1 \mathrm{Ma}$ ) (Kennett et al., 2000) was also found but appears in only two samples (Table T8).

The most striking change in the planktonic foraminiferal assemblage is a change in the coiling direction of neogloboquadrinids (Figs. F18, F19). An abrupt decrease in dextral coiling neogloboquadrinids occurs between 255.29 and 275.74 m CCSF-B (298.55 and $318.99 \mathrm{~m}$ core composite depth below seafloor [CCSF-A]). The timing of this shift roughly corresponds to the interval from the latest part of the $C y$ cladophora sakaii Zone (1.9-3.3 Ma) to the earliest part of the Eucyrtidium matuyamai Zone (1.3-1.9 Ma) and roughly corresponds to the datum event defined by a change in the coiling direction of $N$. pachyderma on the California margin ( $2.0 \mathrm{Ma})$ (Lagoe and Thompson, 1988). However, numerous barren inter- vals make it difficult to constrain the timing of this event in the Gulf of Alaska margin. The relative abundance of dextral coiling specimens of neogloboquadrinids has long been used as an indicator of seasurface temperature during the Quaternary because of their preference for warm-water environments (Kucera, 2007). Taking this environmental preference, as well as the timing of evolutionary changes in the Neogloboquadrina plexus (Kucera and Kennett, 2000), into account, the change in coiling direction is probably due to a major cooling of surface waters beginning around 2.0-2.2 $\mathrm{Ma}$ in the northeastern Pacific.

Brown-colored foraminifer shells were occasionally observed in the core catcher samples. Brown-colored shells are dominant in Samples 341-U1417C-14HCC through $16 \mathrm{H}-7 \mathrm{~W}, 49-59 \mathrm{~cm}$ (121.90-140.58 m CCSF-B), and 341-U1417D-28H-CC (222.42 m CCSFB). Brown-colored foraminifers were also reported in the Bering Sea (Cook et al., 2011) and in the northwestern Pacific (Ohkushi et al., 2005). Further studies suggested that this color change in foraminifer shells is attributed to the postdepositional diagenesis during authigenic carbonate precipitation associated with anaerobic methane oxidation (Cook et al., 2011; Uchida et al., 2004). At Site U1417, the pore water profile shows an abrupt drop in alkalinity and a magnesium minimum in the pore waters between $\sim 200$ and $300 \mathrm{~m}$ CCSF-B. These pore water features are coincident with the occurrence of brownish foraminifer shells, suggesting the precipitation of authigenic carbonates within that interval (see "Geochemistry").

\section{Benthic foraminifers}

Of the 105 core catcher samples that were examined from Holes U1417A-U1417D, 52 contained benthic foraminifers, but abundances were generally low (Figs. F17). Low abundances and numerous barren intervals may reflect dissolution and/or dilution by siliciclastic particles and diatoms. Sixty-nine species or species groups are identified (Table T9), although identifications should be taken as tentative. Benthic foraminiferal assemblages at this site are dominated by individuals in the $63-150 \mu \mathrm{m}$ size fraction in most samples. However, assemblages from Samples 341-U1417D-62X-CC (435.36 m CCSF-B) and 64XCC (444.49 m CCSF-B) are dominated by individuals $>150 \mu \mathrm{m}$. Assemblages are diverse, with $\sim 3-25$ species or species groups per sample for those samples that contain at least 10 individuals (median $=10$ species/sample). Preservation of foraminifers ranges from very good to poor, with poor preservation observed in $\sim 40 \%$ of the core catchers (Table T9; Fig. F17). 
The taxonomic composition among samples is highly variable with respect to the rare taxa (Table T9). However, the samples can be grouped into three main assemblage types united by their most abundant taxa. The majority of samples contain assemblages with dominant to abundant Gyroidina spp. and major contributions from Melonis pompilioides, Pullenia salisburyi, and Eilohedra vitrea. This composition is consistent with middle to lower bathyal environments from the modern Gulf of Alaska (Bergen and O'Neil, 1979) and with the present water depth of Site U1417.

Cassidulina teretis dominates some samples, including Samples 341-U1417D-62X-CC and 64X-CC, where coal and plant material is also preserved (see "Lithostratigraphy"). In the Gulf of Alaska, C. teretis and other Cassidulina species are most abundant in middle to outer neritic environments (Bergen and O'Neil, 1979), suggesting transport from shallower waters. Species considered indicative of shelf environments from Oregon to Alaska, including Triferina angulosa, Quinqueloculina sp., Lagena laevis, Eggerella advena, and Karrierella baccata (see Culver and Buzas, 1985), are also occasionally encountered at Site U1417, further suggesting transport of foraminifers from the shelf to the deep ocean.

Nonionella labradorica and Buccella inusitata characterize a third assemblage that occurs in Samples 341U1417D-3H-CC to $6 \mathrm{H}-\mathrm{CC}$ (23.06-47.80 m CCSF-B). $N$. labradorica is reported to reach abundances $>10 \%$ at $200 \mathrm{~m}$ water depth in the Gulf of Alaska, with a second increase below $\sim 1500-2000 \mathrm{~m}$ water depth (Bergen and O'Neil, 1979). These species are also characteristic of Pliocene to Pleistocene assemblages from the Japan Trench area interpreted to be from 1500-2000 m water depth (Keller, 1980). Thus, this assemblage also suggests transport from environments shallower than the present water depth at Site U1417.

\section{Other microfossils}

\section{Ostracods}

Ostracods were present in 10 samples examined for benthic foraminifers but were not taxonomically described (comments in Table T9).

\section{Calcareous nannofossils}

Calcareous nannofossils were found in isolated intervals in Holes U1417B-U1417D. Overall, the number of species observed was very low ( 2-5 species/sample), which is likely the result of either dissolution or environmental influence. The most common species found are Coccolithus pelagicus, Dictyococcites productus, and small reticulofenestrids $(<3 \mu \mathrm{m})$. The small reticulofenestrids may be a combination of specimens of Reticulofenestra and Gephyrocapsa, but no central area structures were observed that allowed identification of Gephyrocapsa. The best-preserved nannofossils are found within diatom-rich intervals in the upper $\sim 130 \mathrm{~m}$ CCSF-B.

\section{Summary}

Age models derived from diatoms, radiolarians, and planktonic foraminifers generally agree (Table T5; Fig. F20). In some intervals, ages were inverted stratigraphically, suggesting reworking or transport of older material to the site. Reworking and transport is also indicated by shallower water benthic foraminifers, diatom resting spores, and coastal diatom specimens (Fig. F19).

The preserved microfossils at Site U1417 provide an excellent opportunity to document the biotic response to climatic change in both the surface and deeper ocean. Marked variations the relative abundances of taxa potentially reflect major changes in global climate variations linked to fluctuations in ice volume and reorganization of North Pacific circulation during the Pliocene and the Pleistocene (Figs. F18, F19). Numerous barren intervals make it difficult to interpret the environmental conditions during the Miocene. However, in intervals where radiolarians are present, the species composition indicates temperate surface water conditions during the Miocene. Both planktonic foraminifers and radiolarians from this site record cooler conditions in the upper $\sim 225 \mathrm{~m}$ CCSF-B than in older parts of the record. Coincidently, the diatom flora shifts to a more diverse assemblage above $\sim 215$ m CCSF-B, with only a few monospecific $C$. marginatus intervals. Low preservation of siliceous microfossils prevents the observation of this transition around this specific depth. Observed barren intervals at the site may be due to either lower diatom and radiolarian productivity or to increased dissolution suggested by the retention of dissolution resistent taxa in nearly barren intervals.

\section{Stratigraphic correlation}

The composite depth scale at Site U1417 was constructed from 0.0 to $750.82 \mathrm{~m} \mathrm{CCSF-A} \mathrm{(as} \mathrm{defined} \mathrm{in}$ "Stratigraphic correlation" in the "Methods" chapter [Jaeger et al., 2014]). The splice consists of one complete and continuous interval from the mudline to $224.2 \mathrm{~m}$ core composite depth below seafloor (CCSF-D). At greater depths, intervals of correlation were found between holes but were not considered sufficiently continuous to warrant development of a deeper "floating" shipboard splice. 
The splice ranges from the top of Core 341-U1417D$1 \mathrm{H}$ (the mudline) through Core $341-\mathrm{U} 1417 \mathrm{C}-22 \mathrm{H}$ (Tables T10, T11). To the extent possible, the splice was constructed from Holes U1417C and U1417D because Hole U1417A was sampled at sea and the shallowest 10 cores from Hole U1417B were recovered during heavy weather, when ship heave compromised the quality of many of the cores. In Hole U1417C, many of the APC cores taken deeper than $\sim 150$ m CCSF-A had significant flow-in, likely due to incomplete penetration. To the extent possible, these intervals were identified and excluded from the splice.

Correlations between holes were accomplished using IODP Correlator software (version 1.695). All splice tie points were checked by examining digital linescan images with Corelyzer (version 2.0.2), linked to Correlator. During coring, real-time development of composite depths and guidance for coring operations relied initially on Special Task Multisensor Logger (STMSL) GRA density and magnetic susceptibility data. The final composite depth scale (CCSF-A) and the splice (CCSF-D scale) are based primarily on the stratigraphic correlation of magnetic susceptibility and GRA density from the Whole-Round Multisensor Logger (WRMSL) (Figs. F21, F22) with verification from NGR and reflectance spectroscopy color data from the Section Half Multisensor Logger (SHMSL).

The CCSF-A and CCSF-D scales were constructed by assuming that the uppermost sediment (the mudline) in Core 341-U1417D-1H represents the sediment/water interface. An approximate mudline was also recovered in Cores 341-U1417A-1H and 341$\mathrm{U} 1417 \mathrm{~B}-1 \mathrm{H}$ and $2 \mathrm{H}$, confirming the fidelity of the top of the recovered interval. Core 341-U1417D-1H serves as the "anchor" in the composite depth scale and is the only core with depths that are the same on the CCSF-A and CCSF-D scales. From this anchor, we worked downhole, correlating variations in core logging data between holes on a core-by-core basis using Correlator.

A few splice tie points are uncertain. In particular, the splice points between 341-U1417C-7H-7, 16.86 $\mathrm{cm}$, and 341-U1417D-7H-1, $34.84 \mathrm{~cm}(62.18 \mathrm{~m}$ CCSF-A), between 341-U1417C-8H-7, $57.10 \mathrm{~cm}$, and 341-U1417A-10H-1，32.74 cm (76.12 m CCSF-A), and between 341-U1417A-21H-3, $135.07 \mathrm{~cm}$, and 341-U1417B-18H-1, $12.14 \mathrm{~cm}$ (186.76 m CCSF-A), all have little overlap to constrain the splice points and should be used cautiously. The tie point between 341-U1417B-22H-4, $47.19 \mathrm{~cm}$, and 341-U1417C$22 \mathrm{H}-1,16.37 \mathrm{~cm}$ (211.29 m CCSF-A), is equivocal.

Within the splice, the CCSF-A depth scale is defined as equivalent to the CCSF-D depth scale. Note that the CCSF-D scale rigorously applies only to the spliced interval. Intervals outside the splice, although available with CCSF-A depth assignments, should not be expected to correlate precisely with fine-scale details within the splice or with other holes because of variation in the relative spacing of features in different holes. Such apparent depth differences of specific features may reflect coring artifacts or fine-scale spatial variations in sediment accumulation and preservation at and below the seafloor.

The cumulative offset between CSF-A and the CCSFA or CCSF-D depth scales is nonlinear (Fig. F23). The affine growth factor (a measure of the fractional stretching of the composite section relative to the drilled interval; see "Stratigraphic correlation" in the "Methods" chapter [Jaeger et al., 2014]) averages 1.1348 at Site U1417 in the APC-cored interval from 0 to $208.8 \mathrm{~m}$ CCSF-A or CCSF-D. Anomalies around this relatively uniform affine growth relationship may be explained by significant ship heave (especially during coring of Hole U1417B), imprecision of tide corrections on coring depths, and potential distortion of cores by piston effects.

The affine growth factor is 1.2608 in the interval from 208.8 to $266.75 \mathrm{~m}$ CCSF-A. This high rate of affine growth is an artifact introduced by construction of the CCSF-A depth scale; because few features correlated well among the holes in this interval, we sometimes appended cores either within or between holes rather than making firm correlations of specific features within cores. This method artificially expands the apparent length of recovered material. At depths greater than the splice, we observed significant correlation among holes between 220.4 and 232.4 m CCSF-A (Cores 341-U1417B-25H and 341$\mathrm{U} 1417 \mathrm{D}-28 \mathrm{H}$ and $30 \mathrm{H})$ and from 259.0 to $263 \mathrm{~m}$ CCSF-A (Cores 341-U1417B-31H, 341-U1418C-26H and $27 \mathrm{H}$, and 341-U1417D-35X and 36X). We considered these correlations not sufficiently reliable to warrant construction of a floating splice or precise tie points between holes.

Deeper than $266.75 \mathrm{~m}$ CCSF-A, cores were recovered with either the XCB or RCB tools. In this interval, affine values were nominally constant at $43.26 \mathrm{~m}$, which is the highest affine value within the APCcored interval (Core 341-U1417C-29H). Exceptions are Cores 341-U1417B-40X and 44X and 341U1417D-45X, 46X, 58X, and 59X. These six cores all include minor adjustments to their affine values to align significant sedimentary features or shipboard observations of paleomagnetic reversals relative to those found in Hole U1417E (which was given a constant affine value of $43.26 \mathrm{~m}$ ). Correlations between holes based on XCB or RCB cores should be considered uncertain. 
Calculation of mass accumulation rates based on the CCSF-A or CCSF-D scales must correct for the affine growth factor. To facilitate this process, the CCSF-B depth scale compressed the CCSF-A and CCSF-D scales into a scale that has the same total depth of sediment column as the interval actually drilled (see "Stratigraphic correlation" in the "Methods" chapter [Jaeger et al., 2014]). The following three equations define transformation of the CCSF-A or CCSFD depth scale into CCSF-B depths (Fig. F23):

From 0 to $208.80 \mathrm{~m}$ CCSF-A/CCSF-D:

$$
\text { CCSF-B }=0.865 \times \text { CCSF-A/CCSF-D. }
$$

From 208.80 to 266.75 m CCSF-A/CCSF-D:

$$
\text { CCSF-B }=0.7392 \times \text { CCSF-A/CCSF-D }+26.307 .
$$

For 266.75 m CCSF-A/CCSF-D:

$$
\text { CCSF-B = CCSF-A/CCSF-D - 43.26. }
$$

\section{Initial age model}

All the available paleomagnetic and biostratigraphic age datums (Tables T5, T12) (see "Paleontology and Biostratigraphy" and "Paleomagnetism") were considered while constructing minimum and maximum shipboard age models (Fig. F24; Table T13); together, these preliminary age models span most of the uncertainty in the shipboard datums. The age models were constructed in the CCSF-B depth scale and are also provided in the CCSF-A depth scale.

When geomagnetic polarity boundaries and/or reversals were observed in several holes, the average depth and its uncertainty were calculated in the CCSF-B scale. All identified paleomagnetic reversals were included in the shipboard minimum and maximum age models.

Uncertainty in the biostratigraphic datums mostly reflects the shipboard sampling interval and the presence of barren zones. Two biostratigraphic datums were considered outliers relative to well-constrained paleomagnetic datums. The LO of the diatom Actinocyclus oculatus (Sample 341-U1417D-9H$3 \mathrm{~W}, 80 \mathrm{~cm}$ ) and the LO of the diatom Neodenticula koizumii (Sample 341-U1417D-15H-3, $130 \mathrm{~cm}$ ) were not included in the maximum and minimum age models. All other biostratigraphic datums were accommodated within the uncertainties of their published ages and relatively coarse shipboard sampling.

Relatively few biostratigraphic datums were detected in the interval from 460 m CCSF-A (416.74 CCSF-B) to the base of the site. For purposes of constraining the oldest ages at Site U1417, we assumed that basaltic basement was at $838 \pm 8 \mathrm{~m}$ CCSF-A $(794.74 \mathrm{~m}$
CCSF-B based on site survey geophysical data). The oceanic basement is Pacific plate basaltic crust that can be associated with Chron C17-C18 based on the EMAG2 magnetic anomalies (Maus et al., 2009), which span from 37 to $41.2 \mathrm{Ma}$ (Ogg, 2012).

Based on these initial shipboard minimum and maximum age models, the interval older than $10 \mathrm{Ma}$ (averaged over 10-39 Ma) has sediment accumulation rates of $<10 \mathrm{~m} / \mathrm{m}$.y. Sediment accumulation rates (averaged within equally spaced increments of 0.5 m.y.) increase through time, peaking at values $>110 \mathrm{~m} / \mathrm{m}$.y. in the intervals $0-1$ and 2-2.5 Ma (Fig. F25). Such a rise in sedimentation rates is consistent with the gradual northward tectonic drift of the site, as well as acceleration of sediment inputs from regional tectonics and glacial forcing (based on the presence of lonestones and diamicts of probable icerafted origin within the last $\sim 2.5$ m.y.) and further acceleration of glacial erosion in the last $\sim 1.0$ m.y., following the MPT (Clark et al., 2006); Fig. F16).

\section{Geochemistry Interstitial water chemistry}

Interstitial water (IW) samples were taken in Holes U1417A and U1417C-U1417E at variable sampling resolution with depth in hole; sampling was designed to include overlaps in the sampled intervals between each successive hole. The following results are expressed on the CCSF-B scale for Site U1417 (see "Stratigraphic correlation").

In Hole U1417A, 26 IW samples were taken with a resolution of three samples per core in Cores 341U1417A-1H and $2 \mathrm{H}$, two samples per core in Cores $3 \mathrm{H}$ through $6 \mathrm{H}$, and one sample per core deeper than Core $6 \mathrm{H}$. Whole rounds for IW analyses were 5 $\mathrm{cm}$ long in Cores 341-U1417A-1H through $16 \mathrm{H}$ and $10 \mathrm{~cm}$ long in Cores $17 \mathrm{H}$ through $22 \mathrm{H}$. All samples from Hole U1417A were collected from APC cores (0-165.14 m CCSF-B). In Hole U1417C, 11 IW samples were taken from Cores 341-U1417C-17H through $28 \mathrm{H}$ (149.09-221.65 m CCSF-B), with a more irregular depth resolution (1-2 samples per core) than in Hole U1417A depending upon core recovery. In Hole U1417D, 13 IW samples were taken from Cores 341-U1417D-32H through 59X (207.15$421.22 \mathrm{~m}$ CCSF-B), with irregular spacing due to variable core recovery.

In Hole U1417E, 22 IW samples were taken from Cores 341-U1417E-7R through 39R (401.26-643.84 $\mathrm{m}$ CCSF-B). Hole U1417E was drilled using the RCB system, which has the potential for contamination of IW samples by surface seawater and drilling muds (e.g., Chambers and Cranston, 1991). However, suc- 
cessful recovery of uncontaminated RCB sequences for IW analysis has been reported (e.g., Shipboard Scientific Party, 2000; Fulthorpe et al., 2011). The intervals of higher $(>40 \%)$ recovery in Hole U1417E allowed IW sampling on complete 10 or $15 \mathrm{~cm}$ long whole rounds, and we did not identify evidence for contamination with seawater in the chemical analyses (see below). The compositions of IW samples taken from overlapping depths between the different holes were in good agreement, allowing construction of composite IW records. All chemical parameters analyzed in the IW samples at Site U1417 are similar to respective low-resolution data from original Site 178 drilled in 1971 at the same location (Kulm et al., 1973; Waterman et al., 1973).

The applied squeezing pressures ranged from 8,000 to $28,000 \mathrm{psi}$, and the amounts of extracted IW ranged between 25 and $40 \mathrm{~mL}$. Splits of the IW samples were taken and processed following methods outlined in "Geochemistry" in the "Methods" chapter (Jaeger et al., 2014). IW splits also were preserved for shore-based analysis of dissolved trace metals, oxygen/sulfur/calcium/strontium isotopes, dissolved inorganic carbon, and silica.

\section{Alkalinity, pH, chloride, and salinity}

An alkalinity peak occurs at 28.9 m CCSF-B (16.1 $\mathrm{mM}$ ), followed by a decrease to $3.6 \mathrm{mM}$ by $218.0 \mathrm{~m}$ CCSF-B (Fig. F26A). A second peak occurs at $375.6 \mathrm{~m}$ CCSF-B (12.6 mM) before an overall downcore decrease, with some small oscillations, to $2.23 \mathrm{mM}$ (702.8 m CCSF-B). The $\mathrm{pH}$ values fluctuate between 7.36 and 8.28. We observed an overall increase in both the range and absolute $\mathrm{pH}$ values downcore at Site U1417 (Fig. F26B).

Chloride (titrated) concentrations range between 546 and $565 \mathrm{mM}$ (Fig. F26I), largely without a clear downcore trend apart from a chloride maximum at 37.6 m CCSF-B.

Salinity gradually and steadily decreases from 34 to 30 from 0 to $288.0 \mathrm{~m}$ CCSF-B (Fig. F26H). Salinity remains at 30 deeper than this depth, except for two slight increases to 31 at $375-430 \mathrm{~m}$ CCSF-B and deeper than $662.3 \mathrm{~m}$ CCSF-B.

\section{Dissolved ammonium, phosphate, and silica}

Dissolved ammonium at Site U1417 increases rapidly with depth in the uppermost $20 \mathrm{~m}$, from $0.161 \mathrm{mM}$ (1.3 m CCSF-B) to $1.104 \mathrm{mM}$ (20.3 m CCSF-B) (Fig. F26D). Deeper than $20.3 \mathrm{~m}$ CCSF-B, ammonium concentrations remain between 1.0 and $1.2 \mathrm{mM}$ and then decrease downcore deeper than $400 \mathrm{~m}$ CCSF-B to values $<0.5 \mathrm{mM}$.
Phosphate concentrations are highest in the upper $30 \mathrm{~m}$, with maxima at $14.6 \mathrm{~m}$ CCSF-B $(38.2 \mu \mathrm{M})$ and $28.9 \mathrm{~m}$ CCSF-B $(35.5 \mu \mathrm{M})$ (Fig. F27J). Deeper than 29 $\mathrm{m}$ CCSF-B, phosphate rapidly decreases to $12.9 \mu \mathrm{M}$ at $37.6 \mathrm{~m}$ CCSF-B, followed by a more gradual decrease to $3.7 \mu \mathrm{M}$ at $165.1 \mathrm{~m}$ CCSF-B. Phosphate concentrations remain low downcore $(<4 \mu \mathrm{M})$, apart from a slight increase to $\sim 6 \mu \mathrm{M}$ between 300 and 375 m CCSF-B.

Silica concentrations display a number of significant and abrupt transitions (Fig. F26G). A steep increase from 600 to $800 \mu \mathrm{M}$ within the uppermost $15 \mathrm{~m}$ CCSF-B is followed by a more gradual increase to a value of $1054 \mu \mathrm{M}$ at $177.2 \mathrm{~m}$ CCSF-B. Silica concentrations of $\sim 1000 \mu \mathrm{M}$ are sustained downcore, apart from three intervals of low concentrations: 215-290 $\mathrm{m}$ CCSF-B (as low as $300 \mu \mathrm{M}$ ), 518-596 m CCSF-B (as low as $192 \mu \mathrm{M}$ ), and deeper than $643.8 \mathrm{~m} \mathrm{CCSF-B} \mathrm{(as}$ low as $160 \mu \mathrm{M})$.

\section{Dissolved sulfate, calcium, magnesium, potassium, sodium, and bromide}

Sulfate concentrations decrease continuously with depth in the upper $200 \mathrm{~m}$ CCSF-B, from $21.47 \mathrm{mM}$ (1.3 m CCSF-B) to $0.93 \mathrm{mM}$ (207.2 m CCSF-B) (Fig. F26C). Over this depth interval, the sulfate gradient is variable, with the steepest decrease occurring between 1.3 and $20.3 \mathrm{~m}$ CCSF-B (to $16.85 \mathrm{mM}$ ). Total sulfate depletion (to values below the detection limit) is not reached, but deeper than $200 \mathrm{~m}$ CCSF-B, sulfate concentrations remain below $2 \mathrm{mM}$. An increase in sulfate occurs deeper than $643 \mathrm{~m}$ CCSF-B, reaching $\sim 7 \mathrm{mM}$ at 681.8 and $702.8 \mathrm{~m}$ CCSF-B.

Calcium concentrations increase overall with depth at Site U1417, from $10.5 \mathrm{mM}$ (1.3 m CCSF-B) to 30.3 $\mathrm{mM}$ (681.8 m CCSF-B) (Fig. F27A). Two intermediate maxima occur in the upper $90 \mathrm{~m}(12.6 \mathrm{mM}$ at $14.6 \mathrm{~m}$ CCSF-B and $12.4 \mathrm{mM}$ at $52.1 \mathrm{~m} \mathrm{CCSF-B).} \mathrm{A} \mathrm{steep} \mathrm{in-}$ crease in calcium concentrations deeper than 100.2 $\mathrm{m}$ CCSF-B leads to a third, broad maximum between 207.2 and $254.6 \mathrm{~m}$ CCSF-B $(\sim 16-17 \mathrm{mM})$. Calcium concentrations decrease slightly between 288.0 and $316.3 \mathrm{~m}$ CCSF-B and then increase again to reach values of $\sim 30 \mathrm{mM}$ at the bottom of the hole.

Magnesium concentrations decrease overall with depth, from $50.7 \mathrm{mM}$ (1.3 m CCSF-B) to $15.3 \mathrm{mM}$ (702.8 m CCSF-B) (Fig. F27C). This trend is interrupted by a magnesium increase from 24.0 to 30.5 $\mathrm{mM}$ between 254.6 and $375.6 \mathrm{~m}$ CCSF-B. Calcium and magnesium concentrations are negatively correlated (Pearson's correlation coefficient of -0.93) at Site U1417 deeper than 90 m CCSF-B, indicating a common control over these downcore profiles (discussed further below). 
The potassium profile at Site U1417 shows an overall downcore decrease in two main steps: from $11.2 \mathrm{mM}$ at $1.3 \mathrm{~m}$ CCSF-B to $8.6 \mathrm{mM}$ at $100.2 \mathrm{~m}$ CCSF-B and from $6.7 \mathrm{mM}$ at $421.2 \mathrm{~m}$ CCSF-B to $3.8 \mathrm{mM}$ at 574.9 $\mathrm{m}$ CCSF-B (Fig. F27B). Deeper than $600 \mathrm{~m}$ CCSF-B, potassium concentrations increase to reach $5.6 \mathrm{mM}$ at the bottom of the hole (702.8 m CCSF-B).

Sodium concentrations at Site U1417 mostly range between 463 and $480 \mathrm{mM}$, with the highest values between 9.5 and $20.3 \mathrm{~m}$ CCSF-B (Fig. F26J). An increased range of sodium concentrations is recorded deeper than $100 \mathrm{~m}$ CCSF-B, with an overall downcore increase from 100 to $260 \mathrm{~m}$ CCSF-B. A sharp drop in sodium concentration occurs at $400 \mathrm{~m}$ CCSF$\mathrm{B}$, followed by an overall downcore increase to the bottom of the hole.

Bromide concentrations at Site U1417 increase steeply between 1.3 and $12.1 \mathrm{~m}$ CCSF-B and remain $\sim 0.9 \mathrm{mM}$ down to $700 \mathrm{~m}$ CCSF-B (Fig. F26E).

\section{Dissolved manganese, iron, barium, strontium, boron, and lithium}

Both iron and manganese concentrations at Site U1417 are highest in the uppermost $100 \mathrm{~m}$ CCSF-B, decreasing downcore from maximum concentrations of 18 and $112 \mu \mathrm{M}$, respectively (Fig. F27H-F27I). Deeper than $100 \mathrm{~m}$ CCSF-B, iron concentrations are below the quantification limit. In contrast, manganese concentrations are more variable and show a number of maxima and minima (ranging between 5 and $43 \mu \mathrm{M})$.

Barium concentrations are $<10 \mu \mathrm{M}$ in the uppermost $100 \mathrm{~m}$ CCSF-B at Site U1417 (Fig. F27F). Between 100 and 215 m CCSF-B, barium concentrations double; they further increase to $440 \mu \mathrm{M}$ in the interval between 200 and $620 \mathrm{~m}$ CCSF-B. Farther downcore, barium decreases to low values $(\sim 30 \mu \mathrm{M})$ by $643 \mathrm{~m}$ CCSF-B. Detectable barium concentrations are limited to the sediment interval with lowest sulfate concentrations.

Strontium concentrations at Site U1417 first increase slowly and then more rapidly from $\sim 100 \mu \mathrm{M}$ at the top of the record to as high as $180 \mu \mathrm{M}$ by $215 \mathrm{~m}$ CCSF-B (Fig. F27G). Between 215 and $600 \mathrm{~m}$ CCSF$\mathrm{B}$, strontium remains around $180 \mu \mathrm{M}$. Deeper than this interval, strontium concentrations slightly decrease to $\sim 130 \mu \mathrm{M}$ again to the bottom of the hole.

Boron concentrations display a pronounced maximum in the uppermost 45 m CCSF-B of Site U1417, reaching values of $650 \mu \mathrm{M}$ (Fig. F27E). Deeper than this depth, boron decreases to values around $300 \mu \mathrm{M}$ by $240 \mathrm{~m}$ CCSF-B and mostly ranges between 200 and $300 \mu \mathrm{M}$ to the bottom of the hole.
Lithium concentrations at Site U1417 decrease within the uppermost $10 \mathrm{~m}$ CCSF-B from 32 to 12 $\mu \mathrm{M}$ and then slowly increase downcore and reach 24 $\mu \mathrm{M}$ at $\sim 240 \mathrm{~m}$ CCSF-B (Fig. F27D). Deeper than 260 $\mathrm{m}$ CCSF-B, lithium concentrations increase more steeply, reaching values of $55 \mu \mathrm{M}$ by $\sim 410 \mathrm{~m}$ CCSF-B. Following a local minimum and another maximum, lithium concentrations decrease to $34 \mu \mathrm{M}$ around $565 \mathrm{~m}$ CCSF-B, followed by a steep increase to maximum values of $103 \mu \mathrm{M}$ at the bottom of the hole.

\section{Volatile hydrocarbons}

Headspace gas samples were collected at a resolution of one per core in Holes U1417A (Cores 1H through 22H), U1417B (Cores 21H through 47X), U1417D (Cores 32H through 65X), and U1417E (Cores 7R through 39R). Methane is by far the dominant hydrocarbon gas detected in Holes U1417A and U1417B and most of Hole U1417D and remains at low concentrations (generally $<7 \mathrm{ppmv}$ ) to $424.7 \mathrm{~m}$ CCSF-B (Fig. F26F). Slightly elevated methane concentrations are found in the uppermost $130 \mathrm{~m} \mathrm{(5-13}$ ppmv). Deeper than 431.1 m CCSF-B, methane concentrations increase with depth by two to three orders of magnitude in Holes U1417D and U1417E, reaching a maximum of $5117 \mathrm{ppmv}$ at $498.9 \mathrm{~m}$ CCSF-B. In Hole U1417E, methane concentrations decrease abruptly at $643.8 \mathrm{~m}$ CCSF-B. Ethane is present deeper than $439.2 \mathrm{~m}$ CCSF-B in low concentrations $(<2 \mathrm{ppmv}) . \mathrm{C}_{1} / \mathrm{C}_{2}$ ratios thus remain high, between 500 and 5000.

\section{Bulk sediment geochemistry}

IW squeeze cakes and discrete core samples were analyzed from Site U1417 for total carbon, total nitrogen (TN), and total inorganic carbon. From these analyses, total organic carbon (TOC) and calcium carbonate $\left(\mathrm{CaCO}_{3}\right)$ were calculated as described in "Geochemistry" in the "Methods" chapter (Jaeger et al., 2014). In total, 55 samples were analyzed from Hole U1417A (Cores 1H through 22H), 1 from Hole U1417B (Core 16H-CC), 11 from Hole U1417C (Cores $17 \mathrm{H}$ through $28 \mathrm{H}$ ), 44 from Hole U1417D (Cores 7H through 64X), and 35 from Hole U1417E (Cores 4R through 39R). Discrete samples were selected in collaboration with the Lithostratigraphy group to ensure that the main lithologies were analyzed. All of these geochemical results are consistent with the low-resolution analyses of Site 178 (Kulm et al., 1973).

TOC contents mostly range between 0.1 and 0.6 wt $\%$ at Site U1417 (Fig. F28A-F28B). No consistent trend is discernible in the uppermost $200 \mathrm{~m}$ other than a very slight overall downcore decrease. Deeper 
than $300 \mathrm{~m}$ CCSF-B, TOC increases slightly downcore to $564.7 \mathrm{~m}$ CCSF-B (0.85 wt\%) within lithostratigraphic Unit $\mathrm{V}$, which contains visible plant debris and suspected fragments of coal or shale within a diamict facies (see "Lithostratigraphy"). Variable but slightly reduced TOC contents occur deeper than $600 \mathrm{~m}$ CCSF-B. Several discrete samples from specific lithologies show elevated TOC contents: two diatom oozes (0.85 wt\%, $357.6 \mathrm{~m}$ CCSF-B; $1.39 \mathrm{wt} \%, 365.0$ $\mathrm{m}$ CCSF-B), diamicts suspected to contain coal or shale clasts $(9.08 \mathrm{wt} \%, 364.1 \mathrm{~m}$ CCSF-B; $2.38 \mathrm{wt} \%$, 442.2 m CCSF-B; 1.14 wt $\%, 466.9$ m CCSF-B; 1.49 wt $\%, 681.8 \mathrm{~m}$ CCSF-B), woody debris within a sandy bed (6.49 $\mathrm{wt} \% ; 535.2 \mathrm{~m}$ CCSF-B), and a dark gray mud (1.79 wt\%; $565.0 \mathrm{~m}$ CCSF-B). A TOC content of $59.80 \mathrm{wt} \%$ was recorded for an angular clast suspected to be coal or shale within a diamict unit (441.4 m CCSF-B) (see "Lithostratigraphy").

TN contents range between 0 and $0.2 \mathrm{wt} \%$ at Site U1417 (Fig. F28C). Nitrogen contents are higher overall in Hole U1417A ( 0.1 wt\%) than in the other holes at Site U1417, indicating a systematic bias related to a saturated nitrogen column in the gas chromatograph. There are small fluctuations in $\mathrm{TN}$ deeper than $200 \mathrm{~m}$ CCSF-B (0-0.1 wt\%). Several discrete samples from specific lithologies record higher TN contents: in a diatom ooze $(0.2 \mathrm{wt} \% ; 364.1 \mathrm{~m}$ CCSF-B), in a suspected coal or shale clast (1.0 wt $\%$; $441.4 \mathrm{~m}$ CCSF-B), and in sediment around a pyritized lonestone (1.1 wt $\% ; 143.9 \mathrm{~m}$ CCSF-B).

Organic carbon to $\mathrm{TN}(\mathrm{C} / \mathrm{N})$ ratios range between 0 and 30, increasing progressively downcore from $0-5$ in the uppermost $100 \mathrm{~m}$ CCSF-B to values of $0-30$ at the bottom of the hole. Considerably higher $\mathrm{C} / \mathrm{N}$ ratios (50-60) are recorded in a suspected coal or shale sample (441.4 m CCSF-B) and in woody debris (535.2 $\mathrm{m}$ CCSF-B). C/N ratios in the uppermost 100 $m$ CCSF-B (Hole U1417A) fall within the range of fresh organic matter and are consistent with contributions of terrigenous organics (both refractory eroded material and relatively fresh plant material) matter to modern sediments off Alaska (Walinsky et al. 2009), but these ratios may be underestimated from $\mathrm{C} / \mathrm{N}$ ratios as a result of contributions from the inorganic $\mathrm{N}$ pool (e.g., clay mineral-bound ammonium) (Fig. F28F). This phenomenon has been observed in other low-TOC marine sediments such as in the Arctic Ocean (e.g., Schubert and Calvert, 2001; Jakobsson, 2004). The increasing $\mathrm{C} / \mathrm{N}$ ratios deeper than $100 \mathrm{~m}$ CCSF-B are consistent with a mixed marine-terrigenous origin for the sediments at Site U1417 (see "Lithostratigraphy"). However, determination of the relative contributions of organic and inorganic $\mathrm{N}$ is required to assess this interpretation fully.
$\mathrm{CaCO}_{3}$ contents range mostly between 0 and 1.5 wt $\%$ at Site U1417 (Fig. F28D-F28E). Between 200 and $265 \mathrm{~m}$ CCSF-B and deeper than $345 \mathrm{~m}$ CCSF-B, $\mathrm{CaCO}_{3}$ contents are still low but range from 0 to 3 $\mathrm{wt} \%$. Contents exceeding $2 \mathrm{wt} \%$ include one data point associated with a diatom-rich interval $(4 \mathrm{wt} \%$, 61.1 m CCSF-B; interval 341-U1417A-9H-4W, 74-76 $\mathrm{cm})$. XRD analysis identified the presence of dolomite (see XRD data in the Laboratory Information Management System [LIMS] database) in this sample, which likely accounts for the high inorganic $\mathrm{C}$ percentage and which is not corrected for in the calculations of $\mathrm{CaCO}_{3}$ (see "Geochemistry" in the "Methods" chapter [Jaeger et al., 2014]). A suspected authigenic carbonate layer at 336.9 m CCSF-B (interval 341-U1417D-50X-2, 102-106 cm) has $21 \mathrm{wt} \%$ $\mathrm{CaCO}_{3}$. The maximum $\mathrm{CaCO}_{3}$ value $(38 \mathrm{wt} \%)$ is recorded at $450.9 \mathrm{~m}$ CCSF-B (interval 341-U1417D$64 \mathrm{X}-1 \mathrm{~W}, 0-3 \mathrm{~cm}$ ) in a highly cemented sandstone (low-Mg calcite according to XRD analysis; see XRD data in LIMS).

\section{Interpretation}

Site U1417 geochemistry indicates relatively low rates of organic matter remineralization, reflecting limited input of organic matter to the sediments. The low TOC and TN contents at Site U1417 are typical for an oligotrophic deepwater setting, and sediments are not strongly influenced by diagenetic reactions. A contribution of inorganic $\mathrm{N}$ to the bulk sediment composition, most likely related to claybound ammonium (Schubert and Calvert, 2001), is supported by the continuous downcore depletion of ammonium deeper than $\sim 30 \mathrm{~m}$ CCSF-B. The low Ca$\mathrm{CO}_{3}$ contents are equally typical for a subarctic deepwater setting with high terrigenous dilution, as well as with corrosive bottom waters and overall low biogenic carbonate preservation. The sparse occurrence and low preservation of calcareous micro- and nannofossils support this interpretation (see "Paleontology and biostratigraphy").

A number of IW parameters point to a zone of increased organic matter remineralization between $\sim 10$ and $40 \mathrm{~m}$ CCSF-B at Site U1417 (Figs. F27, F29). Dissimilatory manganese and iron reduction release dissolved manganese, iron, and adsorbed phosphate (potentially also boron) into the pore waters (Froelich et al., 1979). Following upward diffusion, these metals reprecipitate as authigenic manganese and iron (oxyhydr)oxides (Froelich et al., 1979), as seen in the brown sediment layer directly beneath the mudline at Site U1417. Downward diffusion probably leads to precipitation of authigenic manganese and iron carbonates, iron sulfides, iron phosphates, and/or iron-rich clay minerals. Beneath the zone of 
dissimilatory manganese and iron reduction, the steep linear sulfate gradient from the sediment/water interface to $\sim 20-30 \mathrm{~m}$ CCSF-B implies enhanced organoclastic sulfate reduction rates that lead to (1) degradation of organic matter, increasing alkalinity, ammonium, bromide, and phosphate concentrations and (2) production of hydrogen sulfide, reacting with iron oxides to form iron sulfides and releasing iron-bound phosphate (Gieskes, 1973, 1975). The variable pattern and overall low concentrations of methane in this part of the sediment succession ( $\leq 13 \mathrm{ppmv}$ in all samples) do not support the establishment of a distinct sulfate-methane transition zone (SMTZ) but might indicate very low rates of methanogenesis occurring within the uppermost $\sim 100 \mathrm{~m}$ of the sediment column. Deeper than $\sim 30 \mathrm{~m}$ CCSF-B, the sulfate gradient becomes less steep, but sulfate is nevertheless decreasing, indicating continuous sulfate reduction at lower rates in the deeper sediments that leads to almost full sulfate depletion at $200 \mathrm{~m}$ CCSF-B.

From the major diagenetic reaction zone between $\sim 10$ and 40 m CCSF-B, alkalinity, ammonium, bromide, and phosphate diffuse to respective sinks in the sediment or water column. Ammonium might be incorporated into clay minerals, whereas alkalinity and phosphate likely precipitate as authigenic carbonate and apatite, respectively (Hein et al., 1979a; Ruttenberg and Berner, 1993). A distinct sink for alkalinity is located between 215 and $290 \mathrm{~m}$ CCSF-B, and slightly higher inorganic carbon values in this zone (1-2 wt $\left.\% \mathrm{CaCO}_{3}\right)$ and lower IW magnesium concentrations suggest the precipitation of authigenic carbonate (Hein et al., 1979a; Raiswell and Fisher, 2004). This interpretation is supported by the presence of brownish, probably dolomite-coated foraminifers in this depth interval (see "Paleontology and biostratigraphy"), beneath which foraminifer abundance falls from few to barren as alkalinity increases. In addition, the very steep downward phosphate gradient might indicate the formation of Fe(II) phosphates (e.g., vivianite), as indicated by the possible detection of its oxidation products (e.g., koninckite) by XRD analysis (see XRD data in LIMS). Deeper in the sediment, a local alkalinity maximum around $375 \mathrm{~m}$ CCSF-B suggests another zone of enhanced organic matter remineralization, supported by slightly elevated ammonium and phosphate concentrations.

The finding of substantially increased methane concentrations only deeper than $\sim 420$ m CCSF-B but almost total sulfate depletion around $200 \mathrm{~m}$ CCSF-B suggests that sulfate is not currently consumed by anaerobic methane oxidation in an SMTZ. Nevertheless, a discrete sink for alkalinity and magnesium deeper than $375 \mathrm{~m}$ CCSF-B supports precipitation of authigenic carbonate. This process also could explain the occurrence of an indurated/cemented sandstone layer at the bottom of Hole U1417D (450.9 m CCSF-B) that was only partially recovered during coring. Because of problems with the disaggregation of core catcher samples from Hole U1417E (see "Paleontology and biostratigraphy"), foraminifer abundance (and preservation state) and any potential association with the alkalinity sink could not be investigated.

As sulfate concentrations reach lowest values at $\sim 200$ $\mathrm{m}$ CCSF-B, pore water barium concentrations begin to increase with depth, possibly because of the dissolution of biogenic barite (barium sulfate) at greater depths. This dissolution occurs because IW become undersaturated with respect to sulfate (Waterman et al., 1973). The top of the barite dissolution zone is clearly confined by the sulfate penetration depth (the depth of total IW sulfate depletion), and precipitation of authigenic barite is most likely occurring at this geochemical transition (von Breymann et al., 1992). Strontium concentrations seem to follow the barium pattern, which might be related to the relatively high strontium content in barite. The lower boundary of the zone of barium- and strontium-enriched IW is related to a slight but consistent increase in sulfate concentrations deeper than $500 \mathrm{~m}$ CCSF-B. Methane production is roughly confined to the sulfate-depleted zone as well, but a direct overlap of the methane and the sulfate profiles was not observed shallower than the methanogenic zone (possibly because of incomplete methane recovery in low-methane samples and/or a decrease of methane production over time). However, there is a second SMTZ located around $650 \mathrm{~m}$ CCSF-B. Sulfate may be diffusing upward, possibly from a source that exists at, or deeper than, the sediment/basalt contact (D’Hondt, Jørgensen, Miller, et al., 2003), 80-100 m beneath the deepest pore water sample, based on a tentative shipboard correlation to DSDP Leg 18 results (Fig. F30; Kulm, Von Huene, et al., 1973). This hypothesis is supported by lithium concentrations higher than the seawater value of $26 \mu \mathrm{M}$ toward the base of the IW record $(>100 \mu \mathrm{M})$, which are due to leaching of the basalt by seawater (e.g., Mayer, Pisias, Janecek, et al., 1992; Zhang et al., 1998).

The patterns of dissolved calcium, magnesium, and potassium also indicate geochemical transformation processes occurring in the sediments. Calcium might precipitate as authigenic carbonate and/or apatite, possibly explaining its variable pattern in the uppermost 100 m CCSF-B of sediment. However, sources of dissolved calcium located deeper than this may be related to the alteration of volcanic ash or the basalt 
underlying the sediments (Gieskes, 1975; Gieskes and Lawrence, 1981). Alteration of ash/basalt may be responsible for the downcore decrease of magnesium deeper than $\sim 400 \mathrm{~m}$ CCSF-B, suggesting the neo-formation of magnesium-rich clay minerals (e.g., smectites), whereas the magnesium removal around 250 $\mathrm{m}$ CCSF-B is most likely caused by authigenic carbonate formation (see above). Potassium, magnesium, and iron might be incorporated into either clay minerals or zeolites formed by alteration of diatom frustules (Michalopoulos and Aller, 1995). Ironrich clays may be forming (see XRD data in LIMS), but the terrestrial source area also contains iron-rich clay minerals (Hein et al., 1979b).

Dissolved silica concentrations exceed those of modern North Pacific Deep Water $(\sim 160 \mu \mathrm{M})$, indicating dissolution of silica below the seafloor, likely from volcanic ash and/or biogenic opal. High IW silica concentrations correspond to the presence of biosiliceous oozes, whereas IW silica concentrations are low when these oozes are absent between 200 and $300 \mathrm{~m}$ CCSF-B and between 500 and $600 \mathrm{~m}$ CCSF-B (see "Lithostratigraphy"). The potential precipitation of authigenic clay minerals and removal of dissolved silica from the IW might also account, in part, for the low silica concentrations observed between 200 and $300 \mathrm{~m}$ CCSF-B (lithostratigraphic Unit II). At these depths, volcanic ash is present as a silica source (see "Lithostratigraphy"). Diffusion upward from the underlying basalt may explain the trend in dissolved silica deeper than $600 \mathrm{~m}$ CCSF-B, but this depth interval is also marked by the presence of biosiliceous ooze, which may induce higher silica input.

The patterns in chloride, sodium, and (less indicative) salinity in the uppermost $60 \mathrm{~m}$ CCSF-B are most likely related to the burial of higher salinity Last Glacial Maximum seawater that is diffusing away from this subsurface maximum (Figs. F26, F29) (McDuff, 1985; Gieskes et al., 1998).

\section{Physical properties}

Physical properties measurements were taken on samples from each of the five holes drilled at Site U1417 to provide basic information for characterizing the drilled section using whole-round cores, split cores, and discrete samples. After cores were divided into sections, all whole-round sections longer than $\sim 30 \mathrm{~cm}$ were measured through the GRA bulk densitometer and magnetic susceptibility loop on the STMSL at $2.5-5.0 \mathrm{~cm}$ intervals with $2 \mathrm{~s}$ measurements. After reaching thermal equilibrium with ambient temperature $(\sim 4 \mathrm{~h})$, GRA bulk density, magnetic susceptibility, and compressional wave $(P$ wave) velocity were measured with the WRMSL at
$2.5 \mathrm{~cm}$ intervals with $5 \mathrm{~s}$ measurements. Some damaged sections with split and/or patched core liners were too wide to fit through the WRMSL and/or the STMSL loop magnetic susceptibility meters and therefore could not be logged with any of the core logger instrumentation. After WRMSL scanning, whole-round sections were logged for NGR at $10 \mathrm{~cm}$ intervals with eight detectors. Color spectrometry, color reflectance, and magnetic susceptibility were measured on the split cores using the SHMSL at 2.5 $\mathrm{cm}$ resolution. Discrete $P$-wave measurements and shear strength measurements were made on split sediment cores from working-half sections on the Section Half Measurement Gantry. Moisture and density (MAD) were measured on $10 \mathrm{~cm}^{3}$ plugs collected from the working halves. Summaries of all the physical properties measured with the multisensor loggers on each hole, as well as discrete bulk density and $P$-wave velocity, are provided in Figures F31, F32, F33, F34, and F35.

\section{Gamma ray attenuation bulk density}

Variations in GRA bulk density can reflect changes in mineralogy/lithology, consolidation, porosity, and coring disturbance. Whole-round GRA bulk density averages $\sim 1.8 \mathrm{~g} / \mathrm{cm}^{3}$ in the APC cores and displays downhole cyclic variability on the order of $\sim 0.5$ $\mathrm{g} / \mathrm{cm}^{3}$ (Figs. F31, F32, F33, F34, F35). A trend toward higher values with depth in the APC cores is consistent with increasing sediment compaction/consolidation. However, whole-round GRA values abruptly decrease corresponding to the depth at which we transitioned from APC core collection to XCB core collection in Holes U1417B and U1417D (Figs. F32, F34). This transition to decreasing values partially reflects incomplete core recovery associated with $\mathrm{XCB}$ and RCB coring methods, as the width of the recovered sediments fails to completely fill the core liner and the GRA measurements are therefore calibrated for a larger sediment volume than is actually contained in XCB- and RCB-acquired cores.

The negative bias in core logger physical properties measurements associated with a partially filled core liner is confirmed by plotting discrete MAD bulk density values against the equivalent WRMSL GRA bulk density values from corresponding depths in the same core (Fig. F36). When all discrete MAD values from the combined $\mathrm{APC}, \mathrm{XCB}$, and $\mathrm{RCB}$ cores are considered, there is considerable scatter in the relationship with WRMSL GRA bulk density and trend toward lower WRMSL GRA bulk densities relative to discrete samples, with a slope of 0.92. However, when only APC cores (which were almost uniformly recovered with full liners) are considered, the relationship between discrete MAD and WRMSL GRA 
bulk densities collapses onto a linear trend with a slope of $\sim 1$.

\section{Magnetic susceptibility}

Because the WRMSL loop magnetic susceptibility meter has a response function with a $\sim 4.5 \mathrm{~cm}$ width at half height (see "Physical properties" in the "Methods" chapter [Jaeger et al., 2014]), whereas the point-source magnetic susceptibility data is sensitive over $\sim 1 \mathrm{~cm}$, both the point source and loop magnetic susceptibility data sets were smoothed with a Gaussian filter of $10 \mathrm{~cm}( \pm 3 \sigma)$ and then interpolated to constant resolution (note that data in the LIMS database are recorded at their raw measurement resolution). Although the relationship between pointsource magnetic susceptibility and loop magnetic susceptibility appears to be linear, there is an offset in the overall magnitude of the measurements, with loop magnetic susceptibility being on average $1.68 \times$ greater than the point-source measurements (Fig. F37). We evaluate all volumetric magnetic susceptibility measurements in instrument units (IU) because of the lack of available absolute calibration standards (see "Physical properties" in the "Methods" chapter [Jaeger et al., 2014]).

Volumetric WRMSL loop magnetic susceptibility ( $\kappa)$ averages around $\sim 120$ IU downhole at the site (Figs. F31, F32, F33, F34, F35). A few anomalously high values $>1000$ IU in Hole U1417D are associated with fragments of tungsten carbide drill bit teeth that broke off of XCB cutting shoes. Cyclic variability between 50 and $100 \mathrm{IU}$ is present throughout the core, and a trend toward higher values with depth in the APC cores may reflect sediment compaction. A decrease in WRMSL loop magnetic susceptibility and an increase in the difference between loop and magnetic susceptibility deeper than $\sim 190 \mathrm{~m}$ CCSF-B ( 225 m CSF-A) in Holes U1417B and U1417D (Figs. F32, F34) are associated with the transition to XCB core collection and likely reflect reduced sediment diameter in the core liner (as discussed in "Gamma ray attenuation bulk density"). The negative bias observed in loop magnetic susceptibility associated with incompletely filled core liners is consistent with decreases in measured GRA bulk density also driven by the deviation from calibration volume (Fig. F38). After smoothing with a Gaussian filter of $10 \mathrm{~cm}( \pm 3 \sigma)$ to correct for the differing response functions of the instruments, we can use this relationship to generate a volume-corrected mass magnetic susceptibility $(\chi)$ with units of $\mathrm{cm}^{3} / \mathrm{g}$ (Fig. F38). This mass (GRA normalized) magnetic susceptibility can be used to evaluate changes in lithology independent of variable porosity, different coring tech- niques, and recovery efficiencies. Correcting for sediment volume reduces variance in $\chi$ by $\sim 10 \%$ relative to the equivalently smoothed raw WRMSL magnetic susceptibility data normalized by the mean core GRA bulk density.

\section{Compressional wave velocity}

$P$-wave velocity was measured on the WRMSL $P$ wave logger (PWL) (see "Physical properties" in the "Methods" chapter [Jaeger et al., 2014]) in Holes U1417A-U1417D to $\sim 220 \mathrm{~m}$ CSF-A at a resolution of $2.5 \mathrm{~cm}$ (Fig. F39). Reasonable measurements could only be obtained for core depths shallower than $\sim 220 \mathrm{~m}$ CSF-A because of the development of void spaces within the core liners after switching to $\mathrm{XCB}$ coring in Holes U1417B and U1417D. WRMSL Pwave velocity values gradually increase downhole, closely following GRA bulk densities (Figs. F31, F32, F33, F34), ranging from $\sim 1470 \mathrm{~m} / \mathrm{s}$ at the seafloor to $\sim 1650 \mathrm{~m} / \mathrm{s}$ at $\sim 220 \mathrm{~m}$ CSF-A (Fig. F36).

Discrete $P$-wave measurements using the $P$-wave caliper tool (PWC) were taken in Holes U1417A, U1417D, and U1417E with 20 m overlap of measurements between holes. In Holes U1417A and U1417D, PWL and PWC measurements overlapped at all depths shallower than 220 m CCSF-B (Fig. F40). PWC values were automatically picked where possible and manually picked when the automatic picker encountered errors when the calipers did not have sufficient contact with the sample because of very soft sediment or bad coupling with the liner. In cases where both automatic and manual picks were recorded, the manual picks are systematically faster than the automatic picks (Figs. F40, F41). The PWL and automated PWC velocities track well deeper than $\sim 15 \mathrm{~m}$ CCSF-B, and a scatter plot shows that the two measurements are significantly correlated (Fig. F40). However, care must be taken when making interpretations based on the discrete velocity data because the sampling is biased by both core recovery and sampling rate in different lithology types.

Deeper than $200 \mathrm{~m}$ CCSF-B, the rate of velocity change with depth increases to $420 \mathrm{~m}$ CCSF-B (Fig. F41). The inflection point at $\sim 200 \mathrm{~m}$ CCSF-B may be associated with the transition from lithostratigraphic Unit I to Unit II, where the abundances of lonestones and biosiliceous oozes decrease (see "Lithostratigraphy"). Deeper than $\sim 420$ m CCSF-B, elevated velocities $(\sim 2420-5700 \mathrm{~m} / \mathrm{s})$ are correlated to cemented intervals, whereas lower values $(<1650 \mathrm{~m} /$ s) are associated with diatom ooze (Fig. F41) (see "Lithostratigraphy"). 


\section{Natural gamma radiation}

We analyzed NGR at $10 \mathrm{~cm}$ intervals on all wholeround core sections that exceeded $50 \mathrm{~cm}$ in length, with minimum section length limited by the response function of the sodium iodide detectors (see "Physical properties" in the "Methods" chapter [Jaeger et al., 2014]). Each measurement reflects the integration of $5 \mathrm{~min}$ of counts (i.e., $10 \mathrm{~min}$ of counting per section, consisting of $5 \mathrm{~min}$ at each of two positions separated by $10 \mathrm{~cm}$ ). NGR values show downhole cyclic variability between 7 and 50 counts per second (Figs. F31, F32, F33, F34, F35) with a mean and standard deviation of 31 and 6, respectively. As NGR counts reflect minerals that fix K, U, and $\mathrm{Th}$, high-frequency variations are likely associated with changes in lithology. NGR variability parallels trends in GRA bulk density and $P$-wave velocity, which also suggests the dominant influence of terrigenous input. Low NGR values frequently correspond with low magnetic susceptibility and increased lightness $\left(\mathrm{L}^{*}\right)$.

The high-frequency variability in NGR is superimposed on a long-term increase downhole between 0 and $220 \mathrm{~m}$ CCSF-B in Holes U1417A-U1417D, interrupted by a decrease in counts between 220 and 360 $\mathrm{m}$ CCSF-B, and partially recovering to higher values below 360 m CCSF-B (Fig. F42). Low NGR counts deeper than $220 \mathrm{~m}$ CCSF-B may partly be attributed to the smaller diameter of recovered sediment in the core liner and/or section voids during $\mathrm{XCB}$ coring at Holes U1417B and U1417D. For WRMSL magnetic susceptibility, after smoothing the data with a Gaussian filter of $50 \mathrm{~cm}( \pm 3 \sigma)$ to accommodate for the varying response functions of the instruments, we can normalize the volumetric NGR to the WRMSL GRA bulk density to correct for variability in sediment volume. Although this treatment reduces the overall variance in the NGR record by $\sim 50 \%$ relative to the Gaussian-smoothed uncorrected NGR data normalized by the mean core GRA bulk density, the decrease in NGR observed between 225 and $360 \mathrm{~m}$ CCSF-B persists in a reduced form deeper than $300 \mathrm{~m}$ CCSF-B (Fig. F42). We therefore propose that the lower volume-normalized NGR values between 300 and $360 \mathrm{~m}$ CCSF-B correspond to a lithology change in the late Pliocene (see "Lithostratigraphy").

\section{Moisture and density}

MAD bulk density values in Holes U1417A, U1417D, and U1417E were calculated from mass and volume measurements on discrete samples from the working halves of split cores (see "Physical properties" in the "Methods" chapter [Jaeger et al., 2014]). Depending on core recovery, quality, and lithology, one to three samples were taken per core. The lithologies associated with samples were recorded in the log sheet if distinct from the dominant sediment (i.e., a sandy event deposit or a biosiliceous layer). Where lithology is undefined in these records, the sample was taken from the dominant lithology within that core. A total of 220 samples were analyzed for MAD: 58 samples from Hole U1417A, 97 samples from Hole U1417D, and 65 samples from Hole U1417E.

MAD values correspond well with GRA bulk densities measured on the WRMSL in Hole U1417A (Fig. F43). Starting at $225 \mathrm{~m}$ CCSF-B, GRA bulk density values are less than the MAD densities because of reduced sediment diameter recovery in the $\mathrm{XCB}$ and $\mathrm{RCB}$ cores (see "Gamma ray attenuation bulk density"). MAD densities increase downhole to $\sim 300$ m CCSF$\mathrm{B}$, ranging from $\sim 1.5-1.8 \mathrm{~g} / \mathrm{cm}^{3}$ at the seafloor to $\sim 1.8-2.1 \mathrm{~g} / \mathrm{cm}^{3}$ at $\sim 300 \mathrm{~m}$ CCSF-B. From $\sim 300$ to 430 $\mathrm{m}$ CCSF-B a population of low-density samples ranges from $\sim 1.4$ to $\sim 1.8 \mathrm{~g} / \mathrm{cm}^{3}$. At $\sim 430 \mathrm{~m}$ CSF-A, densities increase to $\sim 1.7-2.0 \mathrm{~g} / \mathrm{cm}^{3}$. Between $\sim 430$ and $\sim 700 \mathrm{~m}$ CCSF- $\mathrm{B}$, density remains relatively constant, with increased scatter below $\sim 620 \mathrm{~m}$ CCSF-B associated with biosiliceous layers, sand-rich intervals, and cemented sections (see "Lithostratigraphy").

Bulk grain density values are fairly constant between the seafloor and $\sim 300 \mathrm{~m}$ CCSF-B, ranging between $\sim 2.8$ and $3.0 \mathrm{~g} / \mathrm{cm}^{3}$ (Fig. F44). Variability increases slightly between $\sim 300$ and 430 m CCSF-B, with a population of low bulk grain densities corresponding to low bulk densities. Between $\sim 430$ and $620 \mathrm{~m}$ CCSF-B, variability again decreases, averaging between $\sim 2.8$ and $2.9 \mathrm{~g} / \mathrm{cm}^{3}$. A secondary population of elevated scatter occurs deeper than $620 \mathrm{~m}$ CCSF-B, with grain densities up to $\sim 3 \mathrm{~g} / \mathrm{cm}^{3}$.

Porosity (percent pore space of wet sediment volume) measured on discrete samples decreases with depth to $\sim 310 \mathrm{~m}$ CCSF-B, showing a normal consolidation curve. At $\sim 310 \mathrm{~m}$ CSSF-B, discrete values increase to $\sim 52 \%-62 \%$ and then decrease to $\sim 45 \%$ at $\sim 470 \mathrm{~m}$ CCSF-B (Fig. F44). Deeper than $\sim 620 \mathrm{~m}$ CCSF-B, more scatter was observed because of measurements associated with biosiliceous material and cemented sections. Deeper than $\sim 450 \mathrm{~m}$ CCSF-B, sand-rich sediment and clay and silt sediment show normal consolidation. Diatom-rich sediment shows high porosity, which reflects the presence of the porous diatom frustules (Fig. F44).

\section{Shear strength}

Shear strength measurements were performed on working section halves from Holes U1417A and U1417D using the automated vane shear (AVS) test- 
ing system (see "Physical properties" in the "Methods" chapter [Jaeger et al., 2014]). Efforts were made to avoid the locations of obvious drilling disturbance or cracks in the half-core sample. Measurements were taken as close as possible to the positions of the MAD samples.

Shear strength indicates that sediments range from very soft $(0-20 \mathrm{kPa})$ to very stiff $(120-180 \mathrm{kPa})$. The rate of change of shear strength with depth decreases at $\sim 40 \mathrm{~m}$ CCSF-B (Fig. F45). Values are more scattered deeper than $100 \mathrm{~m}$ CCSF-B. All samples were taken in the dominant lithology of dark gray-greenish mud, so it is unlikely that the increasing variability of shear strength measurements is due to lithology alone. Rather, as the mud gets stiffer with depth, other factors such as cracking may affect the measurement. Shear strength measurements were halted at Core 341-U1417D-43X when samples were sufficiently hardened to break destructively upon penetration of the vane.

\section{Geothermal gradient}

Temperature measurements were conducted using the APCT-3 during APC coring in Hole U1417A. Three temperature measurements were taken in total (Fig. F46A), and a geothermal gradient was successfully obtained (Cores 341-U1417A-4H, 10H, and $13 \mathrm{H})$ between 33.9 and $104.4 \mathrm{~m}$ CSF-A. The best fit line to temperature versus depth data was derived from the results (Fig. F46B):

$$
T(z)=0.0605 \times z+1.9156\left(R^{2}=0.9991\right),
$$

where $T(z)$ is in situ temperature at depth $z$ (m CSFA). The estimated geothermal gradient is therefore $61^{\circ} \mathrm{C} / \mathrm{km}$. Note that this geothermal gradient was established for depths shallower than 120 m CSF-A.

\section{Paleomagnetism}

The natural remanent magnetization (NRM) of Site U1417 archive-half cores was measured before and after alternating field (AF) demagnetization. Peak AFs were restricted to a maximum of $20 \mathrm{mT}$ for sections recovered using the APC system with standard (full and half length) and nonmagnetic core barrels (see "Operations"). Higher AFs of up to $40 \mathrm{mT}$ were used for a few sections recovered using the $\mathrm{XCB}$ and $\mathrm{RCB}$ systems (Table T14). The number of demagnetization steps and the peak field used reflected the demagnetization characteristics of the sediments, the severity of the drill string magnetic overprint, the desire to use low peak fields to preserve the magnetization for future shore-based studies, and the need to maintain core flow through the laboratory. Sections completely disturbed by drilling, as noted by the lithostratigraphy and/or paleomagnetism groups, were not measured. Data associated with intervals affected by obvious drilling deformation or measurement error (flux jumps; e.g., Richter et al., 2007) were culled prior to interpretation.

For sections recovered through APC drilling, the NRM intensities at Site U1417 are strong both before $\left(10^{-1} \mathrm{~A} / \mathrm{m}\right.$, with occasional decimeter-scale intervals of $>25)$ and after $\left(10^{-2} \mathrm{~A} / \mathrm{m}\right)$ demagnetization (Fig. F47). Intensities show variability at both the meter and decameter scales through this part of the sequence, reflecting lithology (see "Lithostratigraphy") and, for the demagnetized intensity, geomagnetic field variability. High intensities of up to $>0.25$ $\mathrm{A} / \mathrm{m}$ before demagnetization are more commonly observed in Holes U1417C and U1417D and could reflect a stress-induced progressive increase in the magnetization of the drill string or bottom-hole assembly (e.g., Richter et al., 2007). No clear correlation was observed between core barrel type (full, half, or nonmagnetic) employed and magnetization.

In the XCB- and RCB-cored materials, magnetic intensity shows greater variability, reflecting lithologic changes and variable core quality (Fig. F48; see "Lithostratigraphy"). NRM intensities after demagnetization continue to be in the $10^{-2} \mathrm{~A} / \mathrm{m}$ range, transitioning to lower values through the $\sim 300-350$ $\mathrm{m}$ CSF-A interval, corresponding to lithostratigraphic Unit IV. Intensities are variable between $\sim 350$ and $475 \mathrm{~m} \mathrm{CSF-A,} \mathrm{corresponding} \mathrm{to} \mathrm{lithostrati-}$ graphic Subunits VA and VC, ranging from $10^{-4}$ to $10^{-2} \mathrm{~A} / \mathrm{m}$. Deeper than $\sim 475 \mathrm{~m}$ CSF-A, intensities are consistently lower, in the $10^{-3}$ to $10^{-4} \mathrm{~A} / \mathrm{m}$ range, and vary on an $\sim 50 \mathrm{~m}$ scale.

In the APC-recovered interval, transformation of depths to CCSF-B (see "Stratigraphic correlation") allows comparison between holes that facilitates polarity interpretation. After demagnetization at peak fields of 10 or $20 \mathrm{mT}$, intensities are reduced to the $10^{-2} \mathrm{~A} / \mathrm{m}$ range and are consistent between all holes (Fig. F47). Steep positive inclinations observed in the APC section prior to demagnetization consistent with a low-coercivity drill string magnetic overprint are removed by peak AF demagnetization of $10 \mathrm{mT}$ in the upper $160 \mathrm{~m}$ CCSF-B (Fig. F49). Within this interval, polarity can be unambiguously determined. Inclinations associated with normal and reversed polarities vary around the values expected (approximately $\pm 72^{\circ}$ ) for a geocentric axial dipole at the site latitude. Declinations show serial correlation withincore. Inclination from Holes U1417A-U1417D documents a continuous sequence (see "Stratigraphic 
correlation"), allowing correlation to the geomagnetic polarity timescale (GPTS; Cande and Kent 1995) on the geologic timescale (Hilgen et al., 2012). When polarity transitions occur within a core, declination changes are consistent with inclination-based polarity interpretations (Fig. F49). The Matuyama/ Brunhes boundary and the upper Matuyama Chronozone (C1r) containing the Jaramillo Subchronozone (C1r.1n) are clearly identified. A short interval of normal polarity deeper than the Jaramillo polarity zone is observed in multiple holes and is correlated with the Cobb Mountain Subchronozone (C1r.2n). Deeper than $160 \mathrm{~m}$ CCSF-B, unambiguous recognition of polarity transitions is more difficult, even in the APC-recovered sections (Fig. F49). We do partially observe the Olduvai (C2n) and Reunion (C2r.1n) Subchronozones and correlate their apparent polarity boundaries to the GPTS. Figure F49 and Tables T12 and T15 document these polarity zonations and corresponding age interpretations.

In the XCB- and RCB-recovered intervals, the Gauss (2An) to Matuyama (2r) polarity transition is clearly observed in correlative sections of Holes U1417B, U1417D, and U1417E (Fig. F50; Table T15). At greater depths, correlations are more ambiguous. Although both negative and positive inclinations were recovered deeper than $\sim 300$ m CCSF-B, with apparent transitions often captured in a single $\mathrm{XCB} / \mathrm{RCB}$ core section, interpretation of directional data is complicated by low core recovery and in particular by biscuiting. The quality of the paleomagnetic record within these few recovered meters suggests either that the extremely condensed section around the observed polarity reversals is recovered from the top, middle, or bottom of the drilled interval or that the recovered interval characterized by hard biscuits and softer slurry represents coherently recovered pieces spread through each drilled interval. The options that limit the stratigraphic emplacement of the coherent biscuits within the softer slurry in the $\mathrm{XCB} /$ $\mathrm{RCB}$ cores include either a narrow episode of recovery near the top or bottom of the drilled interval or evenly distributed recovery through the entire core length. To improve recognition of polarity zonations and to assess the nature of material within the $\mathrm{XCB}$ and RCB cores, we assume the latter option of distributed emplacement and linearly expand each measurement made at $2.5 \mathrm{~cm}$ intervals on the recovered core evenly through the drilled interval depth. This simplistic approach assumes that recovered material is derived equally from within the cored interval. An alternative approach using the biscuit boundaries to guide expansion is beyond the time constraints of shipboard research. The results of this exercise, constrained by biostratigraphy, are shown in Figure F50, revealing a recognizable pattern of polarity reversals in the $\mathrm{XCB} / \mathrm{RCB}$ portions of Holes U1417B, U1417D, and U1417E. Much of the Gauss (C2An) and Gilbert (C2Ar) Chronozones can be recognized and correlated to the GPTS in Holes U1417B, U1417D, and U1417E (Tables T12, T15). However, whether the lowest normal polarity interval observed at $\sim 425 \mathrm{~m}$ CCSF-B reflects the Thvera (C3n.4n) or Sidufjall (C3n.3n) is unclear. At deeper intervals, guided by biostratigraphic datums (see "Paleontology and biostratigraphy"), correlations are made to the top of Chron C3An at $\sim 475 \mathrm{~m} \mathrm{CCSF-}$ $\mathrm{B}$ and to Chron C3Bn at $\sim 585 \mathrm{~m}$ CCSF-B. Deeper than $\sim 600 \mathrm{~m}$ CCSF-B, the placement of polarity boundaries is equivocal.

Shore-based analyses will allow significant refinement of these interpretations. Much of the ambiguity could result from the inability of the low level of AF demagnetization to fully remove the drill string overprint, especially in intervals where $\mathrm{XCB}$ and RCB drilling was applied. Additionally, targeting better preserved and more specific lithologies by discrete sampling will likely lead to more reliable results.

\section{Downhole logging Logging operations}

Logging operations for Site U1417 began after completion of RCB operations in Hole U1417E at $1315 \mathrm{~h}$ (local) on 20 June 2013 to a total depth of $709.5 \mathrm{~m}$ DSF. In preparation for logging, the hole was flushed with a $50 \mathrm{bbl}$ sweep of high-viscosity mud and the RCB bit was released. The pipe was pulled to a depth of $81.4 \mathrm{~m}$ DSF. Four tool strings were deployed in Hole U1417E during logging operations: the triple combo, the FMS-sonic, the MSS, and the VSI (Fig. F51; see "Downhole logging" in the "Methods" chapter [Jaeger et al., 2014]).

The first deployment was the triple combo tool string, which was made up of gamma ray, porosity, density, resistivity, and magnetic susceptibility tools. The tool string was lowered into the hole at $2120 \mathrm{~h}$ on 20 June, completing a downlog to a total depth of $624 \mathrm{~m}$ WSF, where it was blocked from downhole progress by a bridge in the hole. The main uplog pass was then conducted at a speed of $900 \mathrm{ft} / \mathrm{h}$ and ran up through the pipe and past the seafloor. The tool string was run back down the hole for a short repeat pass from $225 \mathrm{~m} \mathrm{WSF}$ at a speed of $1800 \mathrm{ft} / \mathrm{h}$.

The second deployment was the FMS-sonic tool string, after an attempt to run the VSI tool string was postponed because of the presence of marine mammals (see "Operations"). The string was run into the 
hole at $1132 \mathrm{~h}$ on 21 June and reached a total depth of $571 \mathrm{~m} \mathrm{WSF}$, unable to pass a bridged section of the hole. Two full passes of the hole were made from 571 $\mathrm{m}$ WSF: the first at a speed of $1200 \mathrm{ft} / \mathrm{h}$ while recording all Dipole Shear Sonic Imager (DSI) modes (monopole compressional, upper dipole, lower dipole, crossed dipoles, and Stoneley) and the second at $1800 \mathrm{ft} / \mathrm{h}$ while recording only standard DSI modes (monopole compressional, upper dipole, and lower dipole). The tool string was rigged down by $2230 \mathrm{~h}$.

The MSS tool string was run next in Hole U1417E. This run was the first at-sea attempt to deploy the full MSS-B tool (comprising the deep-reading and high-resolution magnetic susceptibility sensors). The tool string was rigged up at $2240 \mathrm{~h}$ and run into the hole, reaching a final depth of $204 \mathrm{~m}$ WSF. The highresolution MSS sensor has a stiff bowspring to keep it eccentralized, which may have prevented the tool string from passing the bridges in shallow sections of the hole. Two full uplog passes were recorded from $204 \mathrm{~m} \mathrm{WSF}$, and the tool was rigged down by $0530 \mathrm{~h}$ on 22 June.

The last tool run was the VSI tool string. Protected Species Observation began at first light on 22 June, and the air gun ramp-up began $1 \mathrm{~h}$ later, as no protected species were observed in the $940 \mathrm{~m}$ diameter exclusion zone for this site (see "Operations"). The air guns were positioned $\sim 7 \mathrm{~m}$ below the sea surface for the vertical seismic profile (VSP) in Hole U1417E. The rig-up of the VSI tool string started at $0545 \mathrm{~h}$, and the air guns were fired every 5-15 $\mathrm{min}$ as the tool string was run into the hole. At $0830 \mathrm{~h}$, the tool string reached a final depth of $218 \mathrm{~m}$ WSF; considerable efforts to reach deeper depths were unsuccessful. It was difficult to get a good clamp with the VSI caliper arm because of the irregular borehole diameter, and many of the recorded seismic waveforms were noisy. Two of the station locations, both closer to $211 \mathrm{~m}$ WSF, yielded reasonable first arrival times. At $1305 \mathrm{~h}$, the tool string was run back up the hole. The tool string was rigged down by $1551 \mathrm{~h}$, and logging operations were complete by $1605 \mathrm{~h}$ on 22 June.

Seas were relatively calm for the duration of logging operations. The average heave was $0.5 \mathrm{~m}$ (peak-topeak).

\section{Data processing and quality assessment}

All logging curves were depth-matched using the total gamma ray log from the main pass of the triple combo as a reference, allowing a unified depth scale to be produced. Features in gamma ray logs from the other tool string passes were aligned to the reference $\log$ to produce a complete depth-matched data set.
Logging data were then depth-shifted to the seafloor as identified by a stepwise increase in the gamma ray value, leading to wireline log matched depth below seafloor (WMSF). The triple combo main pass identified seafloor at $4200 \mathrm{~m}$ water depth.

The quality of the downhole logs was affected by the range in borehole diameter, estimated by the hydraulic caliper on the Hostile Environment LithoDensity Sonde (HLDS) and by the FMS calipers (Figs. F52, F53). The caliper logs show an irregular shape through much of the open borehole (ranging from $<5$ to $\geq 18$ inches [the maximum extent of the HLDS caliper arm]), with up to 13 inches of horizontal range over just a few meters vertical depth. All four tool strings deployed in Hole U1417E were blocked at various depths in the borehole by narrow sections or bridges. Significant problems occurred at 242, 246 , and $624 \mathrm{~m}$ WSF for the triple combo and 300 and $366 \mathrm{~m}$ WSF for the FMS-sonic.

As a result of varying borehole conditions associated with rugosity and borehole diameter, logging data vary in quality. Most logs exhibit anomalous highfrequency variability in the upper $305 \mathrm{~m}$ WMSF section of the hole, where caliper logs indicate that the hole is dominated by thin washouts and bridges, but data quality improves deeper than $305 \mathrm{~m}$ WMSF. In general, gamma ray, resistivity, magnetic susceptibility, and $P$-wave velocity were the least affected by variable hole diameter. Features in gamma ray data associated with very wide or very narrow borehole diameters should be treated with caution; fewer gamma rays reach the tool detector in a wider borehole, and more reach the detector where the borehole is narrower. Density and porosity were highly affected in the upper $305 \mathrm{~m}$ WMSF, with average density values close to water density and anomalously high porosity (close to 100\%) through most of the interval (Fig. F52). Magnetic susceptibility logs show reasonable responses throughout the borehole (see "Magnetic susceptibility logs"), although these logs exhibit a clear downhole drift presumably related to tool temperature.

The quality of the logs can also be assessed by comparison with measurements made on cores from the same site (Fig. F52). Total natural gamma ray from the triple combo show good agreement with scaled NGR core logging data from the base of the pipe to 220 m WMSF. Deeper than $220 \mathrm{~m}$ WMSF, the two data sets show similar trends but the core NGR data are offset, likely due to the change in coring technique at $220 \mathrm{~m}$ WMSF (from the APC system to the XCB system) that can result in a lower volume of sediment being counted (see "Physical properties"). Density logs appear to underestimate formation density in the shallowest $305 \mathrm{~m}$ WMSF interval where 
borehole diameter is highly variable, as shown by comparison with the core-based MAD data shown in Figure F52. However, these data show good correspondence deeper than $305 \mathrm{~m}$ WMSF, where the borehole condition and log quality are improved. Porosity logs are anomalously high throughout the hole, as compared to MAD porosity data. The Accelerator Porosity Sonde was not designed for high-porosity formations ( $>50-60 \mathrm{pu})$ and often overestimates porosity in wide and rugose boreholes; therefore, these data should not be considered in interpretation. Resistivity logs show reasonable responses throughout the hole, despite poor borehole conditions, and postcruise density and porosity estimates may be attempted with caution from resistivity using Archie's relationship (Archie, 1942).

FMS data quality relies on a number of factors, including an in-gauge hole, regular borehole walls, and good contact between the tool's pads and the borehole wall. Processing of the FMS image data allows a speed correction to be applied that takes account of variations in the speed of the tool, including stick and slip, measured by the General Purpose Inclinometry Tool incorporated into the tool string. Two processing methods were applied to the speed-corrected images. Static processing normalizes the entire measured resistivity range for the full depth of the borehole to allow for assessment of large-scale resistivity variations. Dynamic processing rescales the color intensity over a sliding $2 \mathrm{~m}$ depth window to highlight local features. Despite borehole conditions, FMS images seem to be of good quality, with the pads making contact with the borehole walls through much of the logged interval. Large depth shifts $(>0.5 \mathrm{~m})$ were needed through much of the borehole, so the absolute depth reference for these images (wireline log speed-corrected depth below seafloor; WSSF) should be considered with caution.

The DSI recorded P\&S monopole, upper dipole, and lower dipole modes in Hole U1417E. To optimize sonic velocity measurements in this sediment, the monopole and upper dipole utilized standard (high) frequency and the lower dipole transmitted/received at a lower frequency. The resulting slowness data were subsequently converted to acoustic velocities ( $V_{\mathrm{P}}$ [monopole] and $V_{\mathrm{S}}$ [upper and lower dipole]). In Figure F53, distinctive orange-red areas in the $V_{\mathrm{P}}$ and $V_{S}$ tracks indicate greater coherence in recorded sonic waveforms, and blue colors indicate little or no coherence. These data show that although the DSI was able to capture both compressional and flexural arrivals in the deeper intervals of the hole (deeper than $305 \mathrm{~m}$ WMSF), there was no coherence for flexural arrivals in the shallower section, and thus no $V_{\mathrm{S}}$ data were recorded.
In addition, at some depths between the base of the pipe and $\sim 260 \mathrm{~m}$ WMSF, the automatic picking of the wave arrivals (black curve in Fig. F53) failed to recognize the compressional wave because of its proximity to the fluid wave in this very slow formation, and thus no $V_{\mathrm{p}}$ data were recorded. Postcruise processing could refine the $V_{\mathrm{P}}$ profile in the shallowest $305 \mathrm{~m}$ WMSF to provide a better estimate of compressional velocity in the poorly picked interval.

\section{Logging stratigraphy}

Downhole logging data for Hole U1417E are summarized in Figures F52, F53, F54, and F55. The logged interval is divided into two logging units primarily on the basis of borehole condition. Logging Unit 2 is further divided into two subunits on the basis of trends and distinctive features in the gamma ray, resistivity, magnetic susceptibility, and sonic logs.

\section{Logging Unit 1 (base of drill pipe to $305 \mathrm{~m}$ WMSF)}

Logging Unit 1 is characterized by highly variable borehole diameter, ranging from $<5$ inches to the 18 inch limit of the HLDS caliper arm. This irregular borehole shape has an influence on the responses of all logging tools, so the logs in this interval may be compromised by the poor borehole condition. Within this unit, the gamma ray, magnetic susceptibility, and $P$-wave velocity logs appear to display coherent character despite centimeter-scale noise (Figs. F52, F53, F54). The gamma radiation signal is coherent between the triple combo and FMS-sonic tool strings and ranges from 10 to 66 gAPI. The signal shows a relatively consistent trend from the base of the pipe to $255 \mathrm{~m}$ WMSF, with a mean value of 38 gAPI. Between 255 and $280 \mathrm{~m}$ WMSF, borehole diameter changes dramatically, and all logs are dominated by the effects of hole size. Deeper than $280 \mathrm{~m}$ WMSF, the gamma radiation signal varies around higher values (typically $\sim 50$ gAPI) relative to the shallower section of the hole. Gamma radiation is dominated by the radioactivity of potassium and thorium, with uranium contributing a relatively minor component (Fig. F54). The potassium and thorium curves follow similar patterns throughout this unit and may be tracking clay content, as both potassium and thorium are found in clay minerals. Isolated peaks in thorium at 165 and $235 \mathrm{~m}$ WMSF may be indicative of volcanic ash beds or interbedded sand/silt layers.

Both resistivity (Fig. F52) and $P$-wave velocity (Fig. F53) logs show slightly increasing trends with depth in logging Unit 1 . Local peaks in $P$-wave velocity between 200 and $305 \mathrm{~m}$ WMSF may be correlated with sand/silt layers. 
Magnetic susceptibility data from Hole U1417E generally exhibit lower frequency variations from the base of the drill pipe to $280 \mathrm{~m}$ WMSF, with the exception of local peaks (Fig. F55). High-resolution data show many centimeter-scale features with elevated susceptibility in logging Unit 1; most have sharp boundaries, but several features have gradational boundaries. Deeper than $280 \mathrm{~m}$ WMSF, the amplitude of the background variability in susceptibility increases slightly.

FMS images (example intervals in Fig. F56) show that logging Unit 1 is generally more conductive than Unit 2 . Within Unit 1 there are sharply bounded submeter to multiple meter-scale alternations between highly resistive and highly conductive layers. A distinct interval of higher resistivity observed in the FMS images between 260 and $305 \mathrm{~m}$ WMSF coincides generally with the increase in gamma ray signal in this unit (Fig. F52).

\section{Logging Unit 2 (305-624 m WMSF)}

Logging Unit 2 is distinguished from Unit 1 primarily by improved condition of the borehole wall. Consequently, the logging data are of better quality throughout Unit 2. Although there are still thin washed-out intervals and bridged sections, there are also intervals between 305 and $624 \mathrm{~m}$ WMSF in which the borehole is nearly in gauge ( 10 inches). Logging Unit 2 is divided into two subunits.

\section{Logging Subunit 2A (305-476 m WMSF)}

Logging Subunit $2 \mathrm{~A}$ is characterized by total gamma ray values ranging from 25 to 66 gAPI (mean $=45$ gAPI) (Fig. F54). The gamma ray signal is dominated by Th and $\mathrm{K}$ content, similar to the signal in logging Unit 1. A slightly higher contribution from $U$ in Unit 2 may indicate a greater content of organic matter. The density log gradually increases with depth in this subunit (Fig. F52).

Resistivity (Fig. F52) and $P$-wave velocity logs (Fig. F53) show similar trends, generally increasing in value with depth in Subunit $2 A$. $P$-wave velocity increases from $\sim 1500 \mathrm{~m} / \mathrm{s}$ at the top of the subunit to $>2000 \mathrm{~m} / \mathrm{s}$ at the base. Local resistivity peaks correspond in most cases to $P$-wave velocity peaks, suggesting that both are responses to lithologic variations.

Magnetic susceptibility logs (Figs. F52, F55) display strong variability, with higher amplitude changes than in the overlying unit. Local peaks may indicate the presence of increased detrital sediments and/or centimeter-scale silt beds within a lower susceptibility background. FMS images show that Subunit 2B is a transition zone between a more conductive shal- lower formation and more resistive deeper formation (Fig. F56). These images highlight an alternation between sharp and gradational contacts at the meter scale.

Within Subunit 2A, there is a distinctive interval between $\sim 409$ and $425 \mathrm{~m}$ WMSF in which many of the logs show unusual behavior. Gamma radiation, density, and resistivity values decrease sharply within this interval (Fig. F52) and then increase at the base, whereas $P$-wave increases throughout the interval (Fig. F53). The magnetic susceptibility signal drops significantly until the base, which coincides with a susceptibility peak (Fig. F52). The FMS images show a moderately resistive interval, with a highly resistive layer at the base. Together, these data suggest that there is a discrete layer of unusual character at this depth, with corresponding characteristics in core physical properties data (Fig. F52). However, there is no clear evidence of such a distinct feature observed in cores.

\section{Logging Subunit 2B (476-624 m WMSF)}

Logging Subunit $2 \mathrm{~B}$ is mainly characterized by higher values in gamma radiation and density (Fig. F52). The upper boundary of this subunit is distinguished by an abrupt change in the character of magnetic susceptibility (Fig. F52) to lower amplitude variability and a step decrease in $P$-wave velocity (Fig. F53). The mean gamma ray value is 52 gAPI, and the downhole patterns in $\mathrm{U}$, Th, and $\mathrm{K}$ measurements correspond within this subunit (Fig. F54). A change in the ratio of $\mathrm{Th}$ and $\mathrm{K}$ to the total gamma ray counts relative to Subunit $2 \mathrm{~A}$ may indicate a change in the source of radioisotopic inputs this interval.

Density values are slightly higher than in Subunit $2 \mathrm{~A}$, increasing to $>2.0 \mathrm{~g} / \mathrm{cm}^{3}$ at the base of the logged interval (Fig. F52). The $P$-wave log shows a sharp decrease to $\sim 1600 \mathrm{~m} / \mathrm{s}$ at $480 \mathrm{~m}$ WMSF, followed by a general increase to the base of the logged interval (Fig. F53). Within Subunit 2B, magnetic susceptibility (Fig. F52) displays low to moderate amplitude variation but generally higher values from 540 to $580 \mathrm{~m}$ WMSF, which coincides with a general increase in gamma ray and density logs. FMS images display very resistive material with few sharp contacts and few conductive zones.

\section{Magnetic susceptibility logs}

Site U1417 marks the first at-sea deployment of the full MSS (officially MSS-B), built by Lamont-Doherty Earth Observatory between 2010 and 2012 to replace an earlier version of the tool. Comprising both a deep-reading sensor (MSS-DR), which was also incor- 
porated into the triple combo, and a high-resolution sensor (MSS-HR), the full MSS tool has the capability to make magnetic susceptibility measurements at 10 and $40 \mathrm{~cm}$ vertical resolution.

In Hole U1417E, deep-reading magnetic susceptibility measurements were repeatable between multiple passes of the triple combo tool string (the first logging run), as well as with the MSS tool string (the third logging run) (Figs. F51, F55). High-resolution magnetic susceptibility is also repeatable between multiple passes of the MSS tool string.

The trend superimposed upon all magnetic susceptibility logs is most likely related to internal tool temperature. When the temperature of the MSS increases linearly with depth, for example as observed in the MSS data from all passes with the triple combo tool string, a simple linear temperature correction was applied. This correction was also applied to MSS data from the downlog with the MSS tool string but not to MSS data from the uplog passes because of evidence of nonlinear tool temperature effects. Figure F55 shows the uncorrected and corrected MSS-DR data for the main pass of the triple combo, as well as the similarly corrected high-resolution downlog measurement of the MSS run.

The high-resolution magnetic susceptibility signal appears to track natural gamma ray variation (Fig. F55). The small $(<1 \mathrm{~m})$ vertical offset observed could come from the discrepancy between the vertical resolution of the Hostile Environment Natural Gamma Ray Sonde $(\sim 20-30 \mathrm{~cm})$ and the MSS-HR sensor $(\sim 10$ $\mathrm{cm})$. As expected, the high-resolution magnetic susceptibility data seem to record more fine-scale features than either gamma radiation or deep-reading susceptibility measurements. For example, at $116 \mathrm{~m}$ WMSF, the high-resolution data show multiple higher amplitude peaks, whereas the deep-reading data show only one broad peak in accordance with different vertical resolutions of the two sensors (see "Downhole logging" in the "Methods" chapter [Jaeger et al., 2014]).

In general, the trends and high values of magnetic susceptibility from the deep-reading and high-resolution measurements in Hole U1417E are the same. Postcruise investigations using core-based magnetic susceptibility data from Site U1417, for which a composite splice exists to $220 \mathrm{~m}$ CCSF-D, should help to understand temperature response and improve the calibration of the MSS, as well as better resolve highresolution susceptibility variations at this site.

\section{Formation MicroScanner images}

Despite the rugosity of the borehole wall associated with high-frequency changes in borehole diameter,
FMS resistivity images reveal differences in textures and lithologies throughout the logged interval of Hole U1417E (Fig. F56). In the statically processed images from FMS-sonic Pass 1, the submeter-scale alternating intervals of conductive and resistive lithologies characterizing logging Unit 1 are shown in contrast to the moderately resistive to highly resistive units in logging Subunit 2A and the highly resistive lithologies in logging Subunit 2B (example sections in Fig. F56). Based on the images, most if not all of the bedding in the logged interval has horizontal to subhorizontal orientation. The boundaries between different layers are generally distinct, though there are more sharp boundaries observed in Unit 1 than in Unit 2.

\section{Vertical seismic profile and sonic velocity}

One objective of the expedition was to establish the age and lithologic origin of the seismic reflections identified in the seismic survey data in the Gulf of Alaska. The VSP provides a good intermediate step in integrating the core and wireline logging data (recorded in depth) with seismic data (recorded in twoway traveltime).

Data acquired during the VSP are summarized in Table T16 and Figures F51 and F57. Although >45 shots were fired, most of the sonic waveforms recorded downhole during the VSP were noisy because of the limited extent of accessible open hole and the rugose borehole wall through this interval. The VSI caliper arm had a difficult time achieving good clamping force because of the soft formation and poor contact with the rough borehole wall. Despite these limitations, two stations close to $211 \mathrm{~m}$ WMSF provided check shot arrival times. Figure F57 shows the waveforms measured by the vertical direction geophone of the VSI and the direct arrivals. Table T16 lists the values of the measured and corrected arrival times. The measured traveltimes are the differences between the arrival of the acoustic pulse at a hydrophone located directly below the air gun array and the arrival at the borehole receiver. The corrected traveltimes are the traveltimes from the sea surface to the borehole receiver, which account for the depth of the air guns $(7 \mathrm{~m}$ below sea level for Hole U1417E) and for the depth of the hydrophone below the air guns $(2 \mathrm{~m})$.

Approximating a linear trend, sonic velocities (between 150 and $557 \mathrm{~m} \mathrm{WMSF}$, the interval with the best $P$-wave data quality) increase downhole at $\sim 0.15$ $\mathrm{km} / \mathrm{s}$ per $100 \mathrm{~m}$. The similarity of the resistivity $\log$ to the sonic velocity log (Fig. F53) indicates that a pseudosonic $\log$, constructed from the resistivity data to extend to $\sim 615 \mathrm{~m} \mathrm{WMSF}$ and calibrated with discrete $P$-wave measurements from cores to extend 
to the base of the hole, could potentially be used as input for a synthetic seismogram.

\section{Core-log-seismic integration}

For the purposes of shipboard data correlation for Site U1417, we compared data displayed in the following two depth scales: WMSF (see "Downhole logging") and CCSF-B (a compressed composite depth scale; see "Stratigraphic correlation") for logging and core data, respectively. Logging data were depth-matched between different tool strings using the gamma ray logs recorded on each logging run and then shifted to the WMSF depth scale based on the step increase in gamma ray across the seafloor (see "Downhole logging" in the "Methods" chapter). For Site U1417, the maximum observed depth shift was $\sim 4 \mathrm{~m}$. Adding this potential error in depth to uncertainties in the depth of a given feature in CCSF-B results in an $\sim 10 \mathrm{~m}$ potential depth error when comparing core-based measurements or lithologic boundaries to downhole logs. Core physical properties were measured in Holes U1417A-U1417E (see "Physical properties"), whereas logging data were recorded only in Hole U1417E (see "Downhole logging").

To begin correlating lithostratigraphic and logging units with features observed in the seismic data, we converted lithostratigraphic and logging unit boundaries from depth in meters (CCSF-B/WMSF) to twoway traveltime (TWT) using the average velocity of each unit. Average $P$-wave velocity was derived from physical properties measurements using data from the WRMSL PWL at depths shallower than $\sim 220 \mathrm{~m}$ CCSF-B and from the downhole sonic logs deeper in the hole (see "Physical properties" and "Downhole logging").

\section{Lithostratigraphy-downhole logging data integration}

We combined sediment core observations and physical properties data with downhole logging data from Site U1417 to (1) evaluate how representative the recovered cores are relative to the portion of the sedimentary section that was logged, (2) determine the nature and extent of sediment not recovered in the $\mathrm{XCB} / \mathrm{RCB}$ drilling process, and (3) examine whether observed sedimentary units and features can be correlated to borehole data and ultimately be described at higher vertical resolution at Site U1417. We first compare magnetic susceptibility measurements made on whole-round and split cores from the shipboard core logging systems (WRMSL and SHMSL; see
"Physical properties") with temperature-corrected downhole data from the deep-reading magnetic susceptibility sensor on the triple combo tool string. We then evaluate whether similar lithostratigraphic units can be characterized by downhole resistivity and natural gamma ray measurements also recorded with the triple combo tool string (see "Downhole logging").

In Figure F58, we compare lithostratigraphic unit boundaries, core recovery, the distribution of diamict intervals, sand-rich units, and magnetic susceptibility measurements recorded in the borehole and on cores. In general, logged and whole-core magnetic susceptibility exhibit similar trends and variability when compared over the same measured interval. We observe that transitions between intervals of high and low magnetic susceptibility in the log data correspond to lithostratigraphic boundaries in the core. These changes are particularly evident at the transitions from lithostratigraphic Units II to III, Units III to IV, and Subunits VC to VD. In areas of lower core recovery, the exact lithostratigraphic unit boundaries may have an error range of a few meters due to recovered intervals being assumed to reside at the top of each cored interval. We also observe an association between relatively high downhole log magnetic susceptibility values and occurrences of sand. Another primary observation is that the highest magnetic susceptibility measured in the downhole logs between 350 and $440 \mathrm{~m}$ CCSF-B corresponds to the occurrence of diamict intervals in lithostratigraphic Subunit VA and at the lithostratigraphic Subunit VB-VC transition (Fig. F58). A photograph of a representative core section (341-U1417D-53X-1, 0$75 \mathrm{~cm}$ ) shows two intervals of diamict with high magnetic susceptibility values separated by an interval of mud with low magnetic susceptibility values (Fig. F58). The image also shows that the diamict intervals consist of fractured and "biscuited" blocks. We speculate that these diamict intervals are responsible for the high magnetic susceptibility values observed in the log data and that poor core recovery (21\% in Core 53X) prevented full representation in the cored record. Lithostratigraphic Unit III is interpreted to be an ice-rafted diamict (see "Lithostratigraphy"), and poor borehole conditions across this interval (270-300 m CCSF-B) may have reduced the amplitude of the logged magnetic susceptibility signal. The base of the ice-rafted diamict interval of lithostratigraphic Unit III correlates with an improvement in borehole conditions for logging (logging Unit 1/2 boundary; see "Downhole logging") to within meters. Overall, the logging data provide evidence for the occurrence of diamict intervals at 
Site U1417. Based on these initial observations, we speculate that the deeper diamicts, possibly representing sediment gravity flow deposits, are a primary part of the sedimentary section between 350 and 400 $\mathrm{m}$ CCSF-B and between 450 and $500 \mathrm{~m}$ CCSF-B and the thickness of these lithologies are underestimated in the cored intervals.

In Figure F59, we compare downhole resistivity; total gamma ray; and $\mathrm{K}$, Th, and $\mathrm{U}$ in standard deviation units to the lithostratigraphy, as well as the distribution of sand, ash, and volcaniclastic lithologies. Resistivity and natural gamma ray profiles are generally low in the shallowest $150 \mathrm{~m}$ of the logged interval ( $~ 80-230 \mathrm{~m}$ WMSF) and exhibit a step increase at $\sim 250 \mathrm{~m}$ WMSF. Resistivity increases from $250 \mathrm{~m}$ WMSF to the base of the logged interval but continues to exhibit a high degree of variability. Low resistivity values in the shallowest $250 \mathrm{~m}$ of the sedimentary section may be related to the occurrence of mud-dominated lithologies. However, borehole dimensions are highly variable within this interval and it is difficult to attribute these variations solely to lithology. In general, we observe multiple examples where volcaniclastic sand/silt corresponds with increases in standardized downhole profiles of total gamma radiation and K. Sand layers generally have high magnetic susceptibility and low gamma ray counts-a good example of this relationship occurs at $450 \mathrm{~m}$ CCSF-B/WMSF. The highly resolved NGR profiles provide an opportunity to map the distribution of facies throughout the logged interval, particularly where there is poor recovery in the drilling process.

\section{Physical properties-downhole logging data correlation}

In general, there seems to be a good correspondence between the physical properties and logging data, with a vertical offset on the order of a few meters. The focus of shipboard correlation was the depth interval from $\sim 305$ to $615 \mathrm{~m}$ CCSF-B/WMSF within logging Subunit 2B, where reasonable borehole conditions resulted in logging data of higher quality (see "Downhole logging;" Fig. F60).

The natural gamma ray log shows good agreement with core NGR to within a few meters depth (Fig. F60); core NGR has been corrected for volume using GRA density (see "Physical properties"). The high degree of correspondence indicates both that the downhole gamma ray log is not compromised by the variability in borehole diameter within this part of the hole and that the volume correction significantly improves the fit between the downhole log and corebased NGR data. The increasing trend with depth in both data sets supports the interpretation of higher natural radioactivity inputs likely associated with relatively muddier lithologies deeper at Site U1417.

The bulk density data also show variable agreement between downhole log, core logger, and discrete core samples. There is more scatter in the GRA density from the core logger; however, the downhole density log values generally correspond to the higher end in the range of GRA density values (Fig. F60). Discrete MAD measurements overlap with the downhole density $\log$, showing a similar range in values. Because core measurements are necessarily limited to recovered intervals and lithologies, comparison of the log and core data suggests that recovery in this part of the hole is biased toward high-density lithologies and that lower density lithologies may not be fully recovered in cores. Although the MAD data are interpreted as showing a change in trend to increasing density below $\sim 470 \mathrm{~m}$ CCSF-B (see "Physical properties"), the density log suggests that the change in trend may occur at a shallower depth $(\sim 420 \mathrm{~m}$ WMSF). There are corresponding changes to increased values in the resistivity and $P$-wave velocity logs at the same depth, suggesting that this depth may represent a significant transition.

Discrete $P$-wave velocity measurements on core show good correspondence with the $P$-wave velocity log to $\sim 430 \mathrm{~m}$ CCSF-B/WMSF (Fig. F60). Deeper in the borehole, the $P$-wave velocity $\log$ shows generally higher velocities than the discrete core data. The lower velocity for the discrete measurements at these deeper intervals could be due to biased core recovery, choice of lithology selected for sampling, or fracturing of the split-core samples during measurements given the increasing induration downcore. However, below $\sim 420 \mathrm{~m}$ CCSF-B, isolated elevated velocities $(>4000 \mathrm{~m} / \mathrm{s})$ are measured on specific discrete samples (not displayed at the scale of Fig. F60) and correlated to cemented intervals in the recovered core, whereas lower velocities are correlated to diatom ooze (see "Lithostratigraphy" and "Physical properties"). The $P$-wave velocity $l o g$, with a sampling interval of $\sim 15 \mathrm{~cm}$ and a vertical resolution of $\sim 100$ $\mathrm{cm}$, may show intermediate velocities as it averages across centimeter-scale variations between faster and slower lithologies.

Magnetic susceptibility data show reasonable agreement between $\log$ and core measurements (Fig. F60). The magnetic susceptibility $\log$, from the deep-reading sensor of the MSS, has been corrected for temperature (see "Downhole logging"). Core magnetic susceptibility data from the loop have been corrected for volume using GRA density (see "Physical properties" 2014). Although there is considerable scatter in the core magnetic susceptibility, there is a clear distinction in the range and am- 
plitude of values across the logging Subunit 2A/2B boundary at $\sim 470-480 \mathrm{~m}$ WMSF. Both $\log$ and core data show higher susceptibility values above $\sim 470 \mathrm{~m}$ CCSF-B/WMSF.

Higher resolution comparison of core and downhole logging data will require detailed correlation of these two data sets. Although core recovery is lower in the $\mathrm{XCB}$ and RCB cored intervals (deeper than $\sim 220 \mathrm{~m}$ CCSF-B), which could limit the success of core-log integration, Figure F60 shows distinctive features in both data sets that can likely be matched more precisely. These efforts can be undertaken postcruise, utilizing the total gamma radiation and magnetic susceptibility data and more detailed comparison to both visual core description and seismic images.

\section{Seismic sequences and correlation with lithostratigraphy and downhole logs}

Seismic Lines MGL1109MSC01 (Fig. F61) and MGL1109MSC14 (Fig. F62), acquired in 2011 aboard the R/V Marcus Langseth, cross Site U1417 (Walton et al., submitted). The primary seismic sequences on each profile, Sequences I-III, are interpreted after Reece et al. (2011). In preparation for core-log-seismic integration, Sequence I was divided into three subsections, IA-IC. Subsection IC was further subdivided into Intervals IC1 and IC2. Each of these sequence boundaries defines either a change in dominant seismic facies or a truncation surface.

Seismic Sequence III is characterized by smooth, continuous reflectors and limited seismic transparency. At Site U1417, the Seismic Sequence II/III boundary ( $5805 \mathrm{~ms}$ TWT) is defined by high-amplitude variation. Below the two prominent reflectors at the top of Sequence II, the section loses amplitude and shows similar seismic characteristics to Sequence III. Based on our estimated depth to TWT conversion, Seismic Sequence III corresponds to lithostratigraphic Unit I: dark gray mud with thin beds of volcanic ash (Subunit IA) and gray mud with thin beds of volcanic ash and diatom ooze (Subunit IB). An increase in lonestones (outsized clasts) in Subunit IB may correspond to a package of higher amplitude reflectors at $\sim 5.71 \mathrm{~s}$ TWT (using a velocity of $1518 \mathrm{~m} / \mathrm{s}$ ) bounded above and below by semitransparent facies (Fig. F30).

Seismic Sequence II is characterized by smooth, continuous reflectors that are semitransparent in the seismic profile. Based on our depth to TWT conversion, this sequence corresponds to lithostratigraphic Units II-IV: gray mud with $1-5 \mathrm{~cm}$ thick interbeds of fine sand and coarse silt (Unit II), thick beds of diamict interbedded with gray mud (Unit III), and a highly bioturbated gray mud with diatom-bearing intervals (Unit IV). Two check shots close to $211 \mathrm{~m}$ WMSF correlate to the seismic data at $5.87 \mathrm{~s}$ TWT within Seismic Sequence II. The Unit III/IV boundary appears to map to the lower part of Seismic Sequence II, where a pair of medium-amplitude reflectors lies just above the high-amplitude package that defines the boundary between Seismic Sequences II and I. The boundary between logging Units 1 and 2 may correlate to increased reflectivity in the lower part of Sequence II (Fig. F30). However, establishing the precise position of lithostratigraphic Units III and IV relative to the Sequence II/I boundary will require more core-log-seismic analysis.

The Seismic Sequence II/I boundary ( $6000 \mathrm{~ms}$ TWT) is located at the top of a prominent grouping of high-amplitude reflectors that are slightly more chaotic and discontinuous than those observed in Sequence II. Sequence I can be divided into three distinct seismic facies packages: Sequence IC, characterized by high-amplitude, semicontinuous reflectors; Sequence IB, a seismically transparent section with faint, semicontinuous reflectors; and Sequence IA, a high-amplitude chaotic layer overlying acoustic basement. Sequence IC is composed of two distinct packages (Sequences IC1 and Sequence IC2) divided by a truncation surface. The base of Sequence I was not penetrated at Site U1417; based on correlation with Site 178, Sequence I is $\sim 400 \mathrm{~m}$ thick at Site 178 (Fig. F30). With our estimated velocities, the lithostratigraphic Unit IV/V boundary at $\sim 350 \mathrm{~m}$ CCSF-B maps to $\sim 6.05 \mathrm{~s}$ TWT, which is at or just below the top of Seismic Sequence I (Fig. F30). A series of thick high-amplitude reflectors comprise this boundary and may be related to the presence of cemented intervals that inhibited core recovery. Lithologically, the boundary between Units IV and V represents a change from to highly bioturbated gray mud with diatom-bearing intervals (Unit IV) to gray mud with diamict, interbedded silt and sand, and diatom ooze (Unit V).

Because of the lack of check shots deeper in the borehole, precise correlation between Seismic Sequence I, lithologic Units IV and V, and logging Unit 2 will need to be undertaken postcruise; however, some comparisons between lithofacies, seismic facies, and log character can be discussed. In general, the increased velocity and density contrasts within logging Subunit 2A and the upper part of Subunit 2B likely correspond to the series of brighter reflectors that define Seismic Sequence IC, and in turn these may correlate with the various lithofacies of lithostratigraphic Unit IV and Subunits VC or VD. The boundary between logging Units $2 \mathrm{~A}$ and $2 \mathrm{~B}$ may be associated with a large negative-amplitude reflector that separates seismic Subunits 1B and 1C at $\sim 6.19 \mathrm{~s}$ 
TWT (Fig. F30). If that correlation is validated, then the remaining lithostratigraphic Subunits VE-VJ and the lower part of logging Unit 2B all lie within Seismic Sequences IB and IA. Correlations deeper in the borehole can be checked against results from Site 178 (Shipboard Scientific Party, 1973), located $~ 1.5$ $\mathrm{km}$ away, by using the basement depth of $780 \mathrm{~m}$ DSF and creating a pinned traveltime/depth boundary at the top of the basement during the creation of a synthetic seismogram.

\section{References}

Addison, J.A., Finney, B.P., Dean, W.E., Davies, M.H., Mix, A.C., Stoner, J.S., and Jaeger, J.M., 2012. Productivity and sedimentary $\delta^{15} \mathrm{~N}$ variability for the last 17,000 years along the northern Gulf of Alaska continental slope. Paleoceanography, 27(1):PA1206. doi:10.1029/ 2011PA002161

Archie, G.E., 1942. The electrical resistivity $\log$ as an aid in determining some reservoir characteristics. J. Pet. Technol., 5:1-8.

Bergen, F.W., and O'Neil, P., 1979. Distribution of Holocene foraminifera in the Gulf of Alaska. J. Paleontol., 53(6):1267-1292. http://www.jstor.org/stable/ 1304134

Berger, A.L., Gulick, S.P.S., Spotila, J.A., Upton, P., Jaeger, J.M., Chapman, J.B., Worthington, L.A., Pavlis, T.L., Ridgway, K.D., Willems, B.A., and McAleer, R.J., 2008a. Quaternary tectonic response to intensified glacial erosion in an orogenic wedge. Nat. Geosci., 1:793-799. doi:10.1038/ngeo334

Berger, A.L., Spotila, J.A., Chapman, J.B., Pavlis, T.L., Enkelmann, E., Ruppert, N.A., and Buscher, J.T., 2008b. Architecture, kinematics, and exhumation of a convergent orogenic wedge: a thermochronoligical investigation of tectonic-climatic interactions within the central St. Elias orogen, Alaska. Earth Planet. Sci. Lett., 270(1-2):1324. doi:10.1016/j.epsl.2008.02.034

Boltovskoy, D., Kling, S.A., Takahashi, K., and Bjørklund, K., 2010. World atlas of distribution of Recent polycystina (Radiolaria). Palaeontol. Electron., 13:1-229. http:// palaeo-electronica.org/2010_3/215/index.html

Brzezinski, M.A., Villareal, T.A., and Lipschultz, F., 1998. Silica production and the contribution of diatoms to new and primary production in the central North Pacific. Mar. Ecol.: Prog. Ser., 167:89-104. doi:10.3354/ meps 167089

Cande, S.C., and Kent, D.V., 1995. Revised calibration of the geomagnetic polarity timescale for the Late Cretaceous and Cenozoic. J. Geophys. Res.: Solid Earth, 100(B4):6093-6095. doi:10.1029/94JB03098

Chambers, S.R., and Cranston, R.E., 1991. Interstitial-water geochemistry of Kerguelen Plateau sediments. In Barron, J., Larsen, B., et al., Proc. ODP, Sci. Results, 119: College Station, TX (Ocean Drilling Program), 347-374. doi:10.2973/odp.proc.sr.119.169.1991

Clark, P.U., Archer, D., Pollard, D., Blum, J.D., Rial, J.A., Brovkin, V., Mix, A.C., Pisias, N.G., and Roy, M., 2006.
The middle Pleistocene transition: characteristics, mechanisms, and implications for long-term changes in atmospheric $\mathrm{pCO}_{2}$. Quat. Sci. Rev., 25(23-24):31503184. doi:10.1016/j.quascirev.2006.07.008

Cook, M.S., Keigwin, L.D., Birgel, D., and Hinrichs, K.-U., 2011. Repeated pulses of vertical methane flux recorded in glacial sediments from the southeast Bering Sea. Paleoceanography, 26(2):PA2210. doi:10.1029/ 2010PA001993

Culver, S.J., and Buzas, M.A., 1985. Distribution of Recent benthic foraminifera off the North American Pacific coast from Oregon to Alaska. Smithsonian Contrib. Mar. Sci., 26.

Davies, M.H., Mix, A.C., Stoner, J.S., Addison, J.A., Jaeger, J., Finney, B., and Wiest, J., 2011. The deglacial transition on the southeastern Alaskan margin: meltwater input, sea level rise, marine productivity, and sedimentary anoxia. Paleoceanography, 26(2):PA2223. doi:10.1029/2010PA002051

D’Hondt, S.L., Jørgensen, B.B., Miller, D.J., et al., 2003. Proc. ODP, Init. Repts., 201: College Station, TX (Ocean Drilling Program). doi:10.2973/odp.proc.ir.201.2003

Dugdale, R.C., Wilkerson, F.P., and Minas, H.J., 1995. The role of a silicate pump in driving new production. DeepSea Res., Part 1, 42(5):697-719. doi:10.1016/09670637(95)00015-X

Elliott, J.L., Larsen, C.F., Freymueller, J.T., and Motyka, R.J., 2010. Tectonic block motion and glacial isostatic adjustment in southeast Alaska and adjacent Canada constrained by GPS measurements. J. Geophys. Res.: Solid Earth, 115(B9):B09407. doi:10.1029/2009JB007139

Enkelmann, E., Zeitler, P.K., Garver, J.I., Pavlis, T.L., and Hooks, B.P., 2010. The thermochronological record of tectonic and surface process interaction at the YakutatNorth American collision zone in southeast Alaska. Am. J. Sci., 310:231-260. doi:10.2475/04.2010.01

Finzel, E.S., Trop, J.M., Ridgway, K.D., and Enkelmann, E., 2011. Upper plate proxies for flat-slab subduction processes in southern Alaska. Earth Planet. Sci. Lett., 303(34):348-360. doi:10.1016/j.epsl.2011.01.014

Froelich, P.N., Klinkhammer, G.P., Bender, M.L., Luedtke, N.A., Heath, G.R., Cullen, D., Dauphin, P., Hammond, D., Hartman, B., and Maynard, V., 1979. Early oxidation of organic matter in pelagic sediments of the eastern equatorial Atlantic: suboxic diagenesis. Geochim. Cosmochim. Acta, 43(7):1075-1090. doi:10.1016/00167037(79)90095-4

Fulthorpe, C.S., Hoyanagi, K., Blum, P., and the Expedition 317 Scientists, 2011. Proc. IODP, 317: Tokyo (Integrated Ocean Drilling Program Management International, Inc.). doi:10.2204/iodp.proc.317.2011

Gasser, D., Bruand, E., Stüwe, K., Foster, D.A., Schuster, R., Fügenschuh, B., and Pavlis, T., 2011. Formation of a metamorphic complex along an obliquely convergent margin: structural and thermochronological evolution of the Chugach Metamorphic Complex, southern Alaska. Tectonics, 30(2):TC2012. doi:10.1029/ 2010TC002776

Gieskes, J.M., 1973. Interstitial water studies, Leg 15: alkalinity, $\mathrm{pH}, \mathrm{Mg}, \mathrm{Ca}, \mathrm{Si}, \mathrm{PO}_{4}$, and $\mathrm{NH}_{4}$. In Heezen, B.C., 
MacGregor, I.D., et al., Init. Repts. DSDP, 20: Washington, DC (U.S. Govt. Printing Office), 813-829. doi:10.2973/dsdp.proc.20.210.1973

Gieskes, J.M., 1975. Chemistry of interstitial waters of marine sediments. Annu. Rev. Earth Planet. Sci., 3:433453. doi:10.1146/annurev.ea.03.050175.002245

Gieskes, J.M., and Lawrence, J.R., 1981. Alteration of volcanic matter in deep-sea sediments: evidence from the chemical composition of interstitial waters from deep sea drilling cores. Geochim. Cosmochim. Acta, 45(10):1687-1703. doi:10.1016/ 0016-7037(81)90004-1

Gieskes, J.M., Schrag, D., Chan, L.-H., Zhang, L., and Murray, R.W., 1998. Geochemistry of interstitial waters. In Saunders, A.D., Larsen, H.C., and Wise, S.W., Jr. (Eds.), Proc. ODP, Sci. Results, 152: College Station, TX (Ocean Drilling Program), 293-305. doi:10.2973/ odp.proc.sr.152.228.1998

Gulick, S.P.S., Jaeger, J.M., Mix, A.C., Asahi, H., Bahlburg, H., Belanger, C., Berbel, G.B.B., Childress, L., Cowan, E., Drab, L., Forwick, M., Fukumura, A., Ge, S., Gupta, S., Kioka, A., Konn, S., LeVay, L.J., März, C., Matsuzaki, K., McClymont, E., Moy, C., Müller, J., Nakamura, A., Ojima, T., Ribiero, F.R., Ridgway, K., Romero, O., Slagle, A., Stoner, J., St.-Onge, G., Suto, I., Walczak, M.D., Worthington, L., Bailey, I., Enkelmann, E., Reece, R., and Swartz, J., submitted. Mid-Pleistocene climate transition drives net mass loss from rapidly uplifting St. Elias Mountains, Alaska. Proc. Natl. Acad. Sci. U. S. A.

Gulick, S.P.S., Lowe, L.A., PavIis, T.L., Gardner, J.V., and Mayer, L.A., 2007. Geophysical insights into the Transition fault debate: propagating strike slip in response to stalling Yakutat block subduction in the Gulf of Alaska. Geology, 35(8):763-766. doi:10.1130/G23585A.1

Gupta, S.M., 1996. Quantitative radiolarian assemblages in surface sediments from the central Indian Basin and their paleomonsoonal significance. J. Geol. Soc. India, 47:339-354. http://drs.nio.org/drs/handle/2264/ 2240

Gupta, S.M., Mohan, R., and Guptha, M.V.S., 2002. Radiolarian fluxes from the southern Bay of Bengal: sediment trap results. Deep-Sea Res., Part I, 49(9):1669-1688. doi:10.1016/S0967-0637(02)00085-7

Gupta, S.M., and Srinivasan, M.S., 1992. Late Miocene radiolarian biostratigraphy and paleoceanography of Sawai Bay Formation, Neill Island, Andamans, India. Micropaleontology, 38(3):209-235. doi:10.2307/1485789

Hamme, R.C., Webley, P.W., Crawford, W.R., Whitney, F.A., DeGrandpre, M.D., Emerson, S.R., Eriksen, C.C., Giesbrecht, K.E., Gower, J.F.R., Kavanaugh, M.T., Peña, M.A., Sabine, C.L., Batten, S.D., Coogan, L.A., Grundle, D.S., and Lockwood, D., 2010. Volcanic ash fuels anomalous plankton bloom in subarctic northeast Pacific. Geophys. Res. Lett., 37(19):L19604. doi:10.1029/2010GL044629

Hasle, G.R., and Syvertsen, E.E., 1996. Marine diatoms. In Tomas, C.R. (Ed.), Identifying Marine Diatoms and Dinoflagellates: San Diego (Academic Press), 5-385. doi:10.1016/B978-012693015-3/50005-X

Hein, J.R., O’Neil, J.R., and Jones, M.G., 1979a. Origin of authigenic carbonates in sediment from the deep Bering
Sea. Sedimentology, 26(5):681-705. doi:10.1111/j.13653091.1979.tb00937.x

Hein, J.R., Yeh, H.-W., and Alexander, E., 1979b. Origin of iron-rich montmorillonite from the manganese nodule belt of the north equatorial pacific. Clays Clay Miner., 27(3):185-194. doi:10.1346/CCMN.1979.0270303

Hilgen, F.J., Lourens, L.J., and Van Dam, J.A., 2012. The Neogene period. In Gradstein, F.M., Ogg, J.G., Schmitz, M.D., and Ogg, G.M. (Eds.), The Geologic Time Scale: Oxford (Elsevier), 923-978. doi:10.1016/B978-0-44459425-9.00029-9

Hogan, L.G., Scheidegger, K.F., Kulm, L.D., Dymond, J., and Mikkelsen, N., 1978. Biostratigraphic and tectonic implications of ${ }^{40} \mathrm{Ar}-{ }^{39} \mathrm{Ar}$ dates of ash layers from the northeast Gulf of Alaska. Geol. Soc. Am. Bull., 89(8):1259-1264. doi:10.1130/00167606(1978)89<1259:BATIOA>2.0.CO;2

Jakobsson, M., Grantz, A., Kristoffersen, Y., Macnab, R., MacDonald, R.W., Sakshaug, E., Stein, R., and Jokat, W., 2004. The Arctic Ocean: boundary conditions and background information. In Stein, R., and MacDonald, R.W., (Eds.), The Organic Carbon Cycle in the Arctic Ocean: Heidelberg (Springer-Verlag), 1-32. doi:10.1007/978-3642-18912-8_1

Jaeger, J.M., Gulick, S.P.S., LeVay, L.J., Asahi, H., Bahlburg, H., Belanger, C.L., Berbel, G.B.B., Childress, L.B., Cowan, E.A., Drab, L., Forwick, M., Fukumura, A., Ge, S., Gupta, S.M., Kioka, A., Konno, S., März, C.E., Matsuzaki, K.M., McClymont, E.L., Mix, A.C., Moy, C.M., Müller, J., Nakamura, A., Ojima, T., Ridgway, K.D., Rodrigues Ribeiro, F., Romero, O.E., Slagle, A.L., Stoner, J.S., St-Onge, G., Suto, I., Walczak, M.H., and Worthington, L.L., 2014. Methods. In Jaeger, J.M., Gulick, S.P.S., LeVay, L.J., and the Expedition 341 Scientists, Proc. IODP, 341: College Station, TX (Integrated Ocean Drilling Program). doi:10.2204/iodp.proc.341.102.2014

Kamikuri, S., Motoyama, I., and Nishimura, A., 2008. Radiolarian assemblages in surface sediments along longitude $175^{\circ} \mathrm{E}$ in the Pacific Ocean. Mar. Micropaleontol., 69(2):151-172. doi:10.1016/j.marmicro.2008.07.005

Katsuki, K., and Takahashi, K., 2005. Diatoms as paleoenvironmental proxies for seasonal productivity, sea-ice and surface circulation in the Bering Sea during the late Quaternary. Deep-Sea Res., Part II, 52(16-18):2110-2130. doi:10.1016/j.dsr2.2005.07.001

Keller, G., 1980. Benthic foraminifers and paleobathymetry of the Japan Trench area, Leg 57, Deep Sea Drilling Project. In Scientific Party, Init. Repts. DSDP, 56, 57: Washington, DC (U.S. Govt. Printing Office), 835-865. doi:10.2973/dsdp.proc.5657.124.1980

Kennett, J.P., Rozo-Vera, G.A., and Machain Castillo, M.L., 2000. Latest Neogene planktonic foraminiferal biostratigraphy of the California margin. In Lyle, M., Koizumi, I., Richter, C., and Moore, T.C. (Eds.), Proc. ODP, Sci. Results, 167: College Station, TX (Ocean Drilling Program), 41-62. doi:10.2973/odp.proc.sr.167.212.2000

Koizumi, I., 2008. Diatom-derived SSTs ( $T d^{\prime}$ ratio) indicate warm seas off Japan during the middle Holocene (8.23.3 kyr BP). Mar. Micropaleontol., 69(3-4):263-281. doi:10.1016/j.marmicro.2008.08.004 
Kreemer, C., Holt, W.E., and Haines, A.J., 2003. An integrated global model of present-day plate motions and plate boundary deformation. Geophys. J. Int., 154(1):834. doi:10.1046/j.1365-246X.2003.01917.X

Kucera, M., 2007. Planktonic foraminifera as tracers of past oceanic environments. In Hillaire, M., and de Vernal, A. (Eds.), Proxies in Late Cenozoic Paleoceanography. Dev. Mar. Geol., 1:213-262. doi:10.1016/S15725480(07)01011-1

Kucera, M., and Kennett, J.P., 2000. Biochronology and evolutionary implications of late Neogene California margin planktonic foraminiferal events. Mar. Micropaleontol., 40(1-2):67-81. doi:10.1016/ S0377-8398(00)00029-3

Kulm, L.D., von Huene, R., et al., 1973. Init. Repts. DSDP, 18: Washington, DC (U.S. Govt. Printing Office). doi:10.2973/dsdp.proc.18.1973

Lagoe, M.B., Eyles, C.H., Eyles, N., and Hale, C., 1993. Timing of late Cenozoic tidewater glaciation in the far North Pacific. Geol. Soc. Am. Bull., 105(12):1542-1560. doi:10.1130/ 0016-7606(1993)105<1542:TOLCTG>2.3.CO;2

Lagoe, M.B., and Thompson, P.R., 1988. Chronostratigraphic significance of late Cenozoic planktonic foraminifera from the Ventura Basin, California: potential for improving tectonic and depositional interpretation. J. Foraminiferal Res., 18(3):250-266. doi:10.2113/ gsjfr.18.3.250

Lagoe, M.B., and Zellers, S.D., 1996. Depositional and microfaunal response to Pliocene climate change and tectonics in the eastern Gulf of Alaska. Mar. Micropaleontol., 27(1-4):121-140. doi:10.1016/03778398(95)00055-0

Lisiecki, L.E., and Raymo, M.E., 2005. A Pliocene-Pleistocene stack of 57 globally distributed benthic $\delta^{18} \mathrm{O}$ records. Paleoceanography, 20(1):PA1003. doi:10.1029/ 2004PA001071

Lowe, D.R., 1982. Sediment gravity flows, II. Depositional models with special reference to the deposits of highdensity turbidity currents. J. Sediment. Petrol., 52(1):279297. http://jsedres.sepmonline.org/cgi/content/ abstract/52/1/279

Maus, S., Barckhausen, U., Berkenbosch, H., Bournas, N., Brozena, J., Childers, V., Dostaler, F., Fairhead, J.D., Finn, C., von Frese, R.R.B., Gaina, C., Golynsky, S., Kucks, R., Lühr, H., Milligan, P., Mogren, S., Müller, R.D., Olesen, O., Pilkington, M., Saltus, R., Schreckenberger, B., Thébault, E., and Caratori Tontini, F., 2009. EMAG2: a 2-arc min resolution Earth Magnetic Anomaly Grid compiled from satellite, airborne, and marine magnetic measurements. Geochem., Geophys., Geosyst., 10(8):Q08005. doi:10.1029/2009GC002471

Mayer, L., Pisias, N., Janecek, T., et al., 1992. Proc. ODP, Init. Repts., 138: College Station, TX (Ocean Drilling Program). doi:10.2973/odp.proc.sr.138.1995

McDuff, R.E., 1985. The chemistry of interstitial waters, Deep Sea Drilling Project Leg 86. In Heath, G.R., Burckle, L.H., et al., Init. Repts. DSDP, 86: Washington, DC (U.S. Govt. Printing Office), 675-687. doi:10.2973/ dsdp.proc.86.131.1985
Medlin, L.K., and Priddle, J. (Eds.), 1990. Polar Marine Diatoms: Cambridge (British Antarct. Surv.).

Michalopoulos, P., and Aller, R.C., 1995. Rapid clay mineral formation in Amazon delta sediments: reverse weathering and oceanic elemental cycles. Science, 270(5236):614-617. doi:10.1126/science.270.5236.614

Molnia, B.F., and Hein, J.R., 1982. Clay mineralogy of a glacially dominated, subarctic continental shelf: northeastern Gulf of Alaska. J. Sediment. Petrol., 52(2):515527. doi:10.1306/212F7F90-2B24-11D78648000102C1865D

Ogg, J.G., 2012. Geomagnetic polarity time scale. In Gradstein, F.M., Ogg, J.G., Schmitz, M.D., and Ogg, G.M. (Eds.), The Geologic Time Scale 2012: Amsterdam (Elsevier), 85-113. doi:10.1016/B978-0-444-594259.00005-6

Ohkushi, K., Ahagon, N., Uchida, M., and Shibata, Y., 2005. Foraminiferal isotope anomalies from northwestern Pacific marginal sediments. Geochem., Geophys., Geosyst., 6(4):Q04005. doi:10.1029/2004GC000787

Plafker, G., 1987. Regional geology and petroleum potential of the northern Gulf of Alaska continental margin. In Scholl, D.W., Grantz, A., and Vedder, J.G. (Eds.), Petroleum Geology Potential of the Continental Margin of Western North America and Adjacent Ocean Basins. Earth Sci. Ser. (N. Y.), 6:229-268.

Powell, R.D., and Molnia, B.F., 1989. Glacimarine sedimentary processes, facies and morphology of the southsoutheast Alaska shelf and fjords. Mar. Geol., 85(24):359-390. doi:10.1016/0025-3227(89)90160-6

Raiswell, R., and Fisher, Q.J., 2004. Rates of carbonate cementation associated with sulphate reduction in DSDP/ODP sediments: implications for the formation of concretions. Chem. Geol., 211(1-2):71-85. doi:10.1016/j.chemgeo.2004.06.020

Rea, D.K., and Snoeckx, H., 1995. Sediment fluxes in the Gulf of Alaska: paleoceanographic record from Site 887 on the Patton-Murray Seamount platform. In Rea, D.K., Basov, I.A., Scholl, D.W., and Allan, J.F. (Eds.), Proc. ODP, Sci. Results, 145: College Station, TX (Ocean Drilling Program), 247-256. doi:10.2973/ odp.proc.sr.145.122.1995

Reece, R.S., Gulick, S.P.S., Christeson, G.L., Horton, B.K., van Avendonk, H., and Barth, G., 2013. The role of farfield tectonic stress in oceanic intraplate deformation, Gulf of Alaska. J. Geophys. Res.: Solid Earth, 118(5):18621872. doi:10.1002/jgrb.50177

Reece, R.S., Gulick, S.P.S., Horton, B.K., Christeson, G.L., and Worthington, L.L., 2011. Tectonic and climatic influence on the evolution of the Surveyor Fan and channel system, Gulf of Alaska. Geosphere, 7(4):830844. doi:10.1130/GES00654.1

Richter, C., Acton, G., Endris, C., and Radsted, M., 2007. Handbook for shipboard paleomagnetists. ODP Tech. Note, 34. doi:10.2973/odp.tn.34.2007

Ruttenberg, K.C., and Berner, R.A., 1993. Authigenic apatite formation and burial in sediments from nonupwelling, continental margin environments. Geochim. 
Cosmochim. Acta, 57(5):991-1007. doi:10.1016/ 0016-7037(93)90035-U

Sakshaug, E., 2004. Primary and secondary production in the Arctic Seas. In Stein, R., and Macdonald, R.W. (Eds.), The Organic Carbon Cycle in the Arctic Ocean: Berlin (Springer-Verlag), 57-81. doi:10.1007/978-3-64218912-8_3

Sancetta, C., 1982. Distribution of diatom species in surface sediments of the Bering and Okhotsk Seas. Micropaleontology, 28(3):221-257. doi:10.2307/1485181

Schubert, C.J., and Calvert, S.E., 2001. Nitrogen and carbon isotopic composition of marine and terrestrial organic matter in Arctic Ocean sediments: implications for nutrient utilization and organic matter composition. Deep-Sea Res., Part I, 48(3):789-810. doi:10.1016/ S0967-0637(00)00069-8

Shipboard Scientific Party, 1973. Site 178. In Kulm, L.D., von Huene, R., et al., Init. Repts. DSDP, 18: Washington, DC (U.S. Govt. Printing Office), 287-376. doi:10.2973/ dsdp.proc.18.109.1973

Shipboard Scientific Party, 2000. Site 1149. In Plank, T., Ludden, J.N., Escutia, C., et al., Proc. ODP, Init. Repts., 185: College Station, TX (Ocean Drilling Program), 1190. doi:10.2973/odp.proc.ir.185.104.2000

Smith, W.H.F., and Sandwell, D.T., 1997. Global seafloor topography from satellite altimetry and ship depth soundings. Science, 277(5334):1956-1962. doi:10.1126/ science.277.5334.1956

Smith, W.O., Jr., Baumann, M.E.M., Wilson, D.L., and Aletsee, L., 1987. Phytoplankton biomass and productivity in the marginal ice zone of the Fram Strait during summer 1984. J. Geophys. Res.: Oceans, 92(C7):67776786. doi:10.1029/JC092iC07p06777

Stevenson, A.J., and Embley, R., 1987. Deep-sea fan bodies, terrigenous turbidite sedimentation, and petroleum geology, Gulf of Alaska. In Scholl, D.W., Grantz, A., and Vedder, J.G. (Eds.), Geology and Resource Potential of the Western North America and Adjacent Ocean Basins-Beaufort Sea to Baja California. Circum-Pac. Counc. Energy Min. Resour., Earth Sci. Ser., 6:503-522.

Swann, G.E.A., Maslin, M.A., Leng, M.J., Sloane, H.J., and Jaug, G.H., 2006. Diatom $\delta^{18} \mathrm{O}$ evidence for the development of the modern halocline system in the subarctic northwest Pacific at the onset of major Northern Hemisphere glaciation. Paleoceanography, 21(1):PA1009. doi:10.1029/2005PA001147

Takahashi, K., Billings, J.D., and Morgan, J.K., 1990. Oceanic province: assessment from the time-series diatom fluxes in the northeastern Pacific. Limnol. Oceanogr., 35(1):154-165. doi:10.4319/1o.1990.35.1.0154
Uchida, M., Shibata, Y., Ohkushi, K., Ahagon, N., and Hoshiba, M., 2004. Episodic methane release events from Last Glacial marginal sediments in the western North Pacific. Geochem., Geophys., Geosyst., 5(8):Q08005. doi:10.1029/2004GC000699

von Breymann, M.T., Brumsack, H., and Emeis, K.C., 1992. Depositional and diagenetic behavior of barium in the Japan Sea. In Pisciotto, K.A., Ingle, J.C., Jr., von Breymann, M.T., Barron, J., et al., Proc. ODP, Sci. Results, 127/ 128 (Pt. 1): College Station, TX (Ocean Drilling Program), 651-665. doi:10.2973/odp.proc.sr.1271281.168.1992

von Huene, R., Larson, E., and Crouch, J., 1973. Preliminary study of ice-rafted erratics as indicators of glacial advances in the Gulf of Alaska. In Kulm, L.D., von Huene, R., et al., Init. Repts. DSDP, 18: Washington (U.S. Govt. Printing Office), 835-842. doi:10.2973/ dsdp.proc.18.121.1973

Walinsky, S.E., Prahl, F.G., Mix, A.C., Finney, B.P., Jaeger, J.M., and Rosen, G.P., 2009. Distribution and composition of organic matter in surface sediments of coastal southeast Alaska. Cont. Shelf Res., 29(13):1565-1579. doi:10.1016/j.csr.2009.04.006

Walton, M.L., Gulick, S.P.S., Reece, R.S., Barth, G.A., Christeson, G.L., and van Avendonk, H., submitted. Tectonic control on deposition and evolution of the Baranof Fan, Gulf of Alaska. Geosphere.

Waterman, L.S., Sayles, F.L., and Manheim, F.T., 1973. Appendix II: interstitial water studies on small core samples, Legs 16, 17, and 18. In Kulm, L.D., von Huene, R., et al., Init. Repts. DSDP, 18: Washington (U.S. Govt. Printing Office), 1001-1012. doi:10.2973/ dsdp.proc.18.app2.1973

Yanagisawa, Y., and Akiba, F., 1998. Refined Neogene diatom biostratigraphy for the northwest Pacific around Japan, with an introduction of code numbers for selected diatom biohorizons. Chishitsugaku Zasshi, 104(6):395-414. doi:10.5575/geosoc.104.395

Zachos, J., Pagani, M., Sloan, L., Thomas, E., and Billups, K., 2001. Trends, rhythms, and aberrations in global climate 65 Ma to present. Science, 292(5517):686-693. doi:10.1126/science.1059412

Zhang, L., Chan, L.-H., and Gieskes, J.M., 1998. Lithium isotope geochemistry of pore waters from Ocean Drilling Program Sites 918 and 919, Irminger Basin. Geochim. Cosmochim. Acta, 62(14):2437-2450. doi:10.1016/ S0016-7037(98)00178-1

Publication: 22 November 2014 MS 341-103 
Figure F1. 3-D perspective view of the bathymetry/topography of the southern Alaska continental margin, showing tectonic boundaries and the Surveyor Fan in high-resolution bathymetry. HSV = Hinchinbrook Sea Valley, ASV = Alsek Sea Valley, BT = Bering Trough, GS $=$ Giacomini Seamount, KT = Kayak Trough, PS = Pamplona Spur, YSV = Yakutat Sea Valley. Plate boundaries adapted from Gulick et al. (2007). High-resolution bathymetry from Gardner et al. (2006). Remaining bathymetry from Smith and Sandwell (1997). Yakutat Terrane motion relative to North America from Elliott et al. (2010). Pacific plate motion from Kreemer et al. (2003). Inset: Location of Alaska Coastal Current (ACC), Alaska Current (AC), and NOAA wave buoy 46001. Modified from Reece et al. (2013).

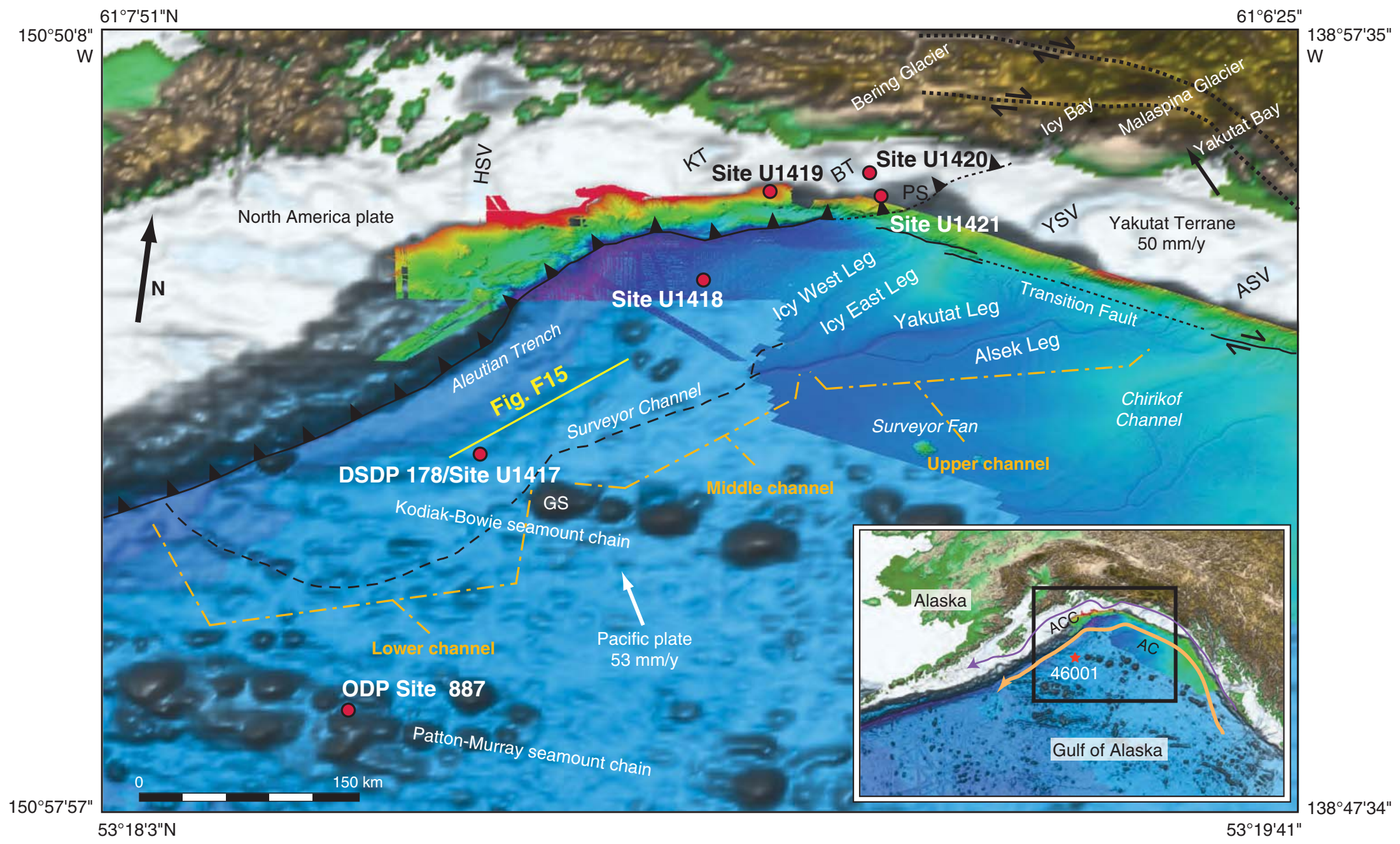


Figure F2. Lithology and age control, DSDP Site 178. Modified from Lagoe et al. (1993). Partial seismic section from Line 13 of 1989 USGS Survey F689 (Fig. F1). IRD = ice-rafted debris, Ja = Jaramillo, OI = Olduvai. GI A, GI $\mathrm{B}, \mathrm{GI} \mathrm{C}=$ Glacial Intervals $\mathrm{A}, \mathrm{B}$, and $\mathrm{C}$. MPW = mid-Pliocene warm period. ${ }^{40} \mathrm{Ar} /{ }^{39} \mathrm{Ar}$ ages from Hogan et al. (1978). Magnetic polarity stratigraphy from von Huene et al. (1973). Modified from Reece et al. (2011).

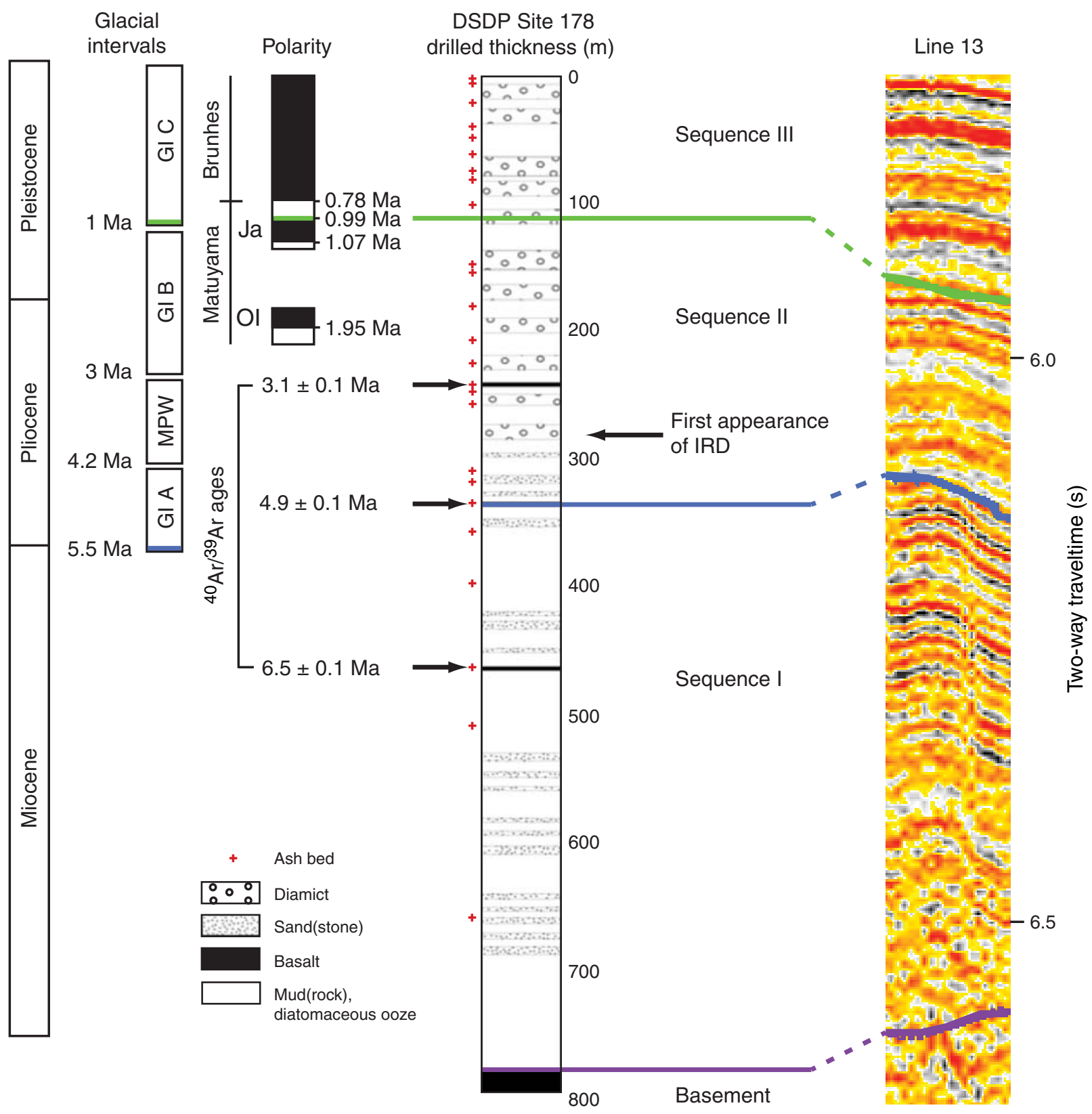


Figure F3. A. From left to right, a seismic transect from MGL1109 Line 1 toward the east, to MGL1109 Line 14 heading northeast, to MGL1109 Line 13 heading east. Seismic sequences can be mapped from Site U1417 to the Surveyor Channel. VE = vertical exaggeration. B. Multibeam bathymetry map showing location of Site U1417, DSDP Site 178, and seismic profiles relative to the Surveyor Channel, Kodiak-Bowie Seamounts, Aleutian Trench, and Kodiak Island, Alaska (Gulick et al., submitted).

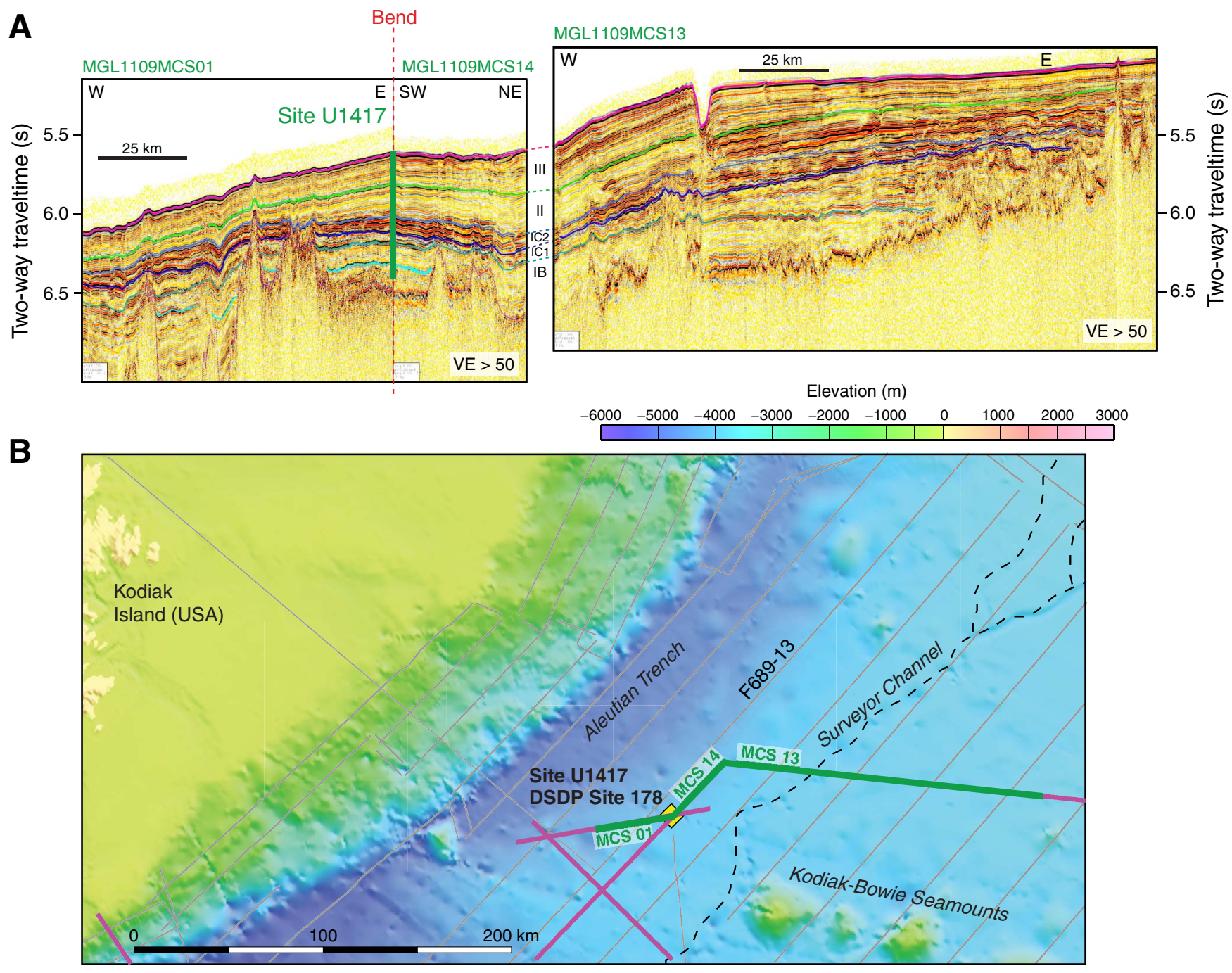


Figure F4. Seismic reflection Line 13 from 1989 USGS Survey F689 showing sequences newly defined by Reece et al. (2013) and approximate correlation to DSDP Site 178. See Figure F1 for line location. Vertical exaggeration (VE) assumes $2000 \mathrm{~m} / \mathrm{s}$ sediment acoustic velocity. Modified from Reece et al. (2011)

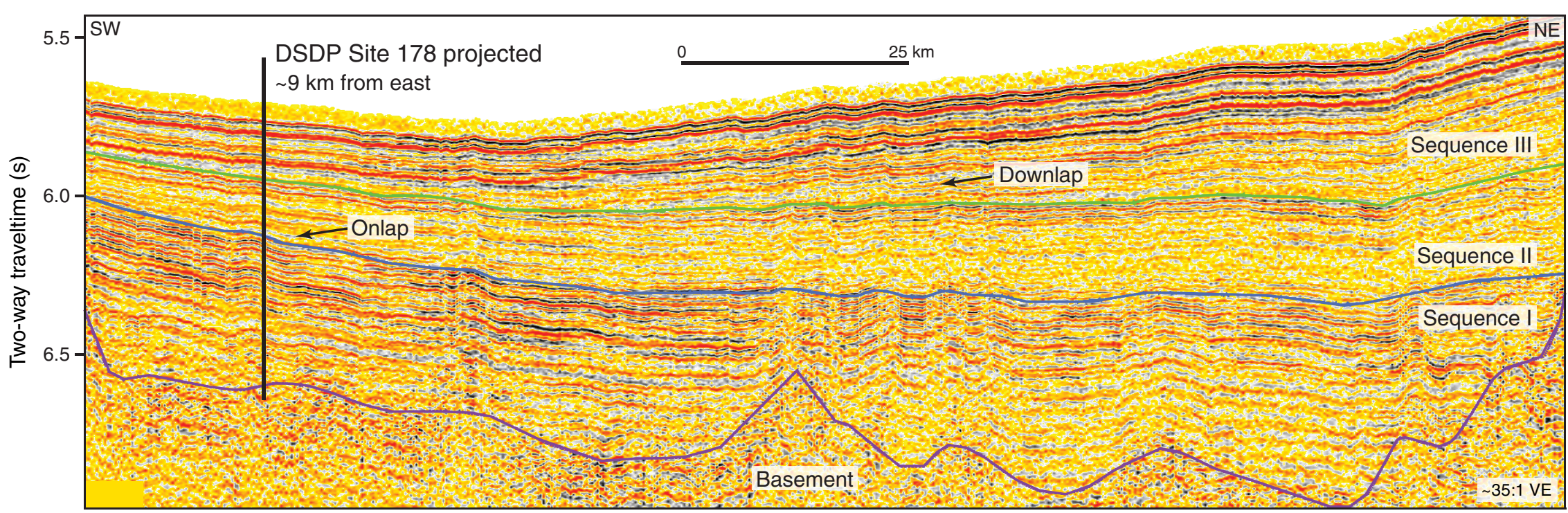


Figure F5. Bathymetry close to Site U1417, showing minimal local topography. Depth is in meters. Site U1417 lies at the intersection of seismic Lines MG1109MCS01 and MGL1109MCS14 and is $\sim 1.5 \mathrm{~km}$ from DSDP Site 178. Red dots are USGS Line L-6-81 with shot point times noted. For MGL1109 lines, numbers refer to shot points.

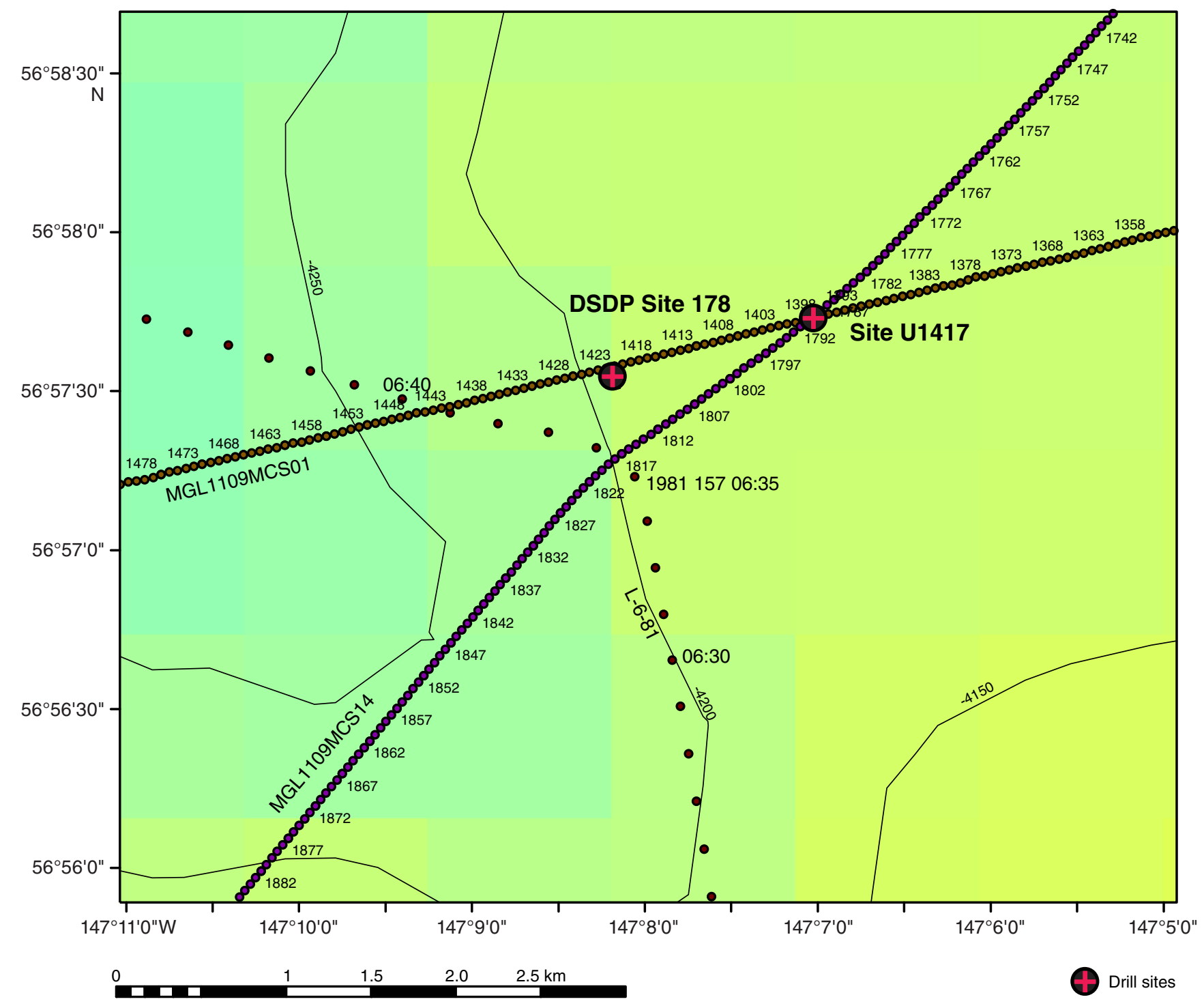


Figure F6. Two-way traveltime thickness maps. A. Sequence I, Pacific plate formation prior to 5.5 Ma. B. Sequence II, 5.5-1 Ma. C. Sequence III, $\sim 1 \mathrm{Ma}$ to present. D. Seismic reflection data track lines used in calculation. ASV = Alsek Sea Valley, BT = Bering Trough, KT = Kayak Trough, YSV = Yakutat Sea Valley. From Reece et al. (2011).

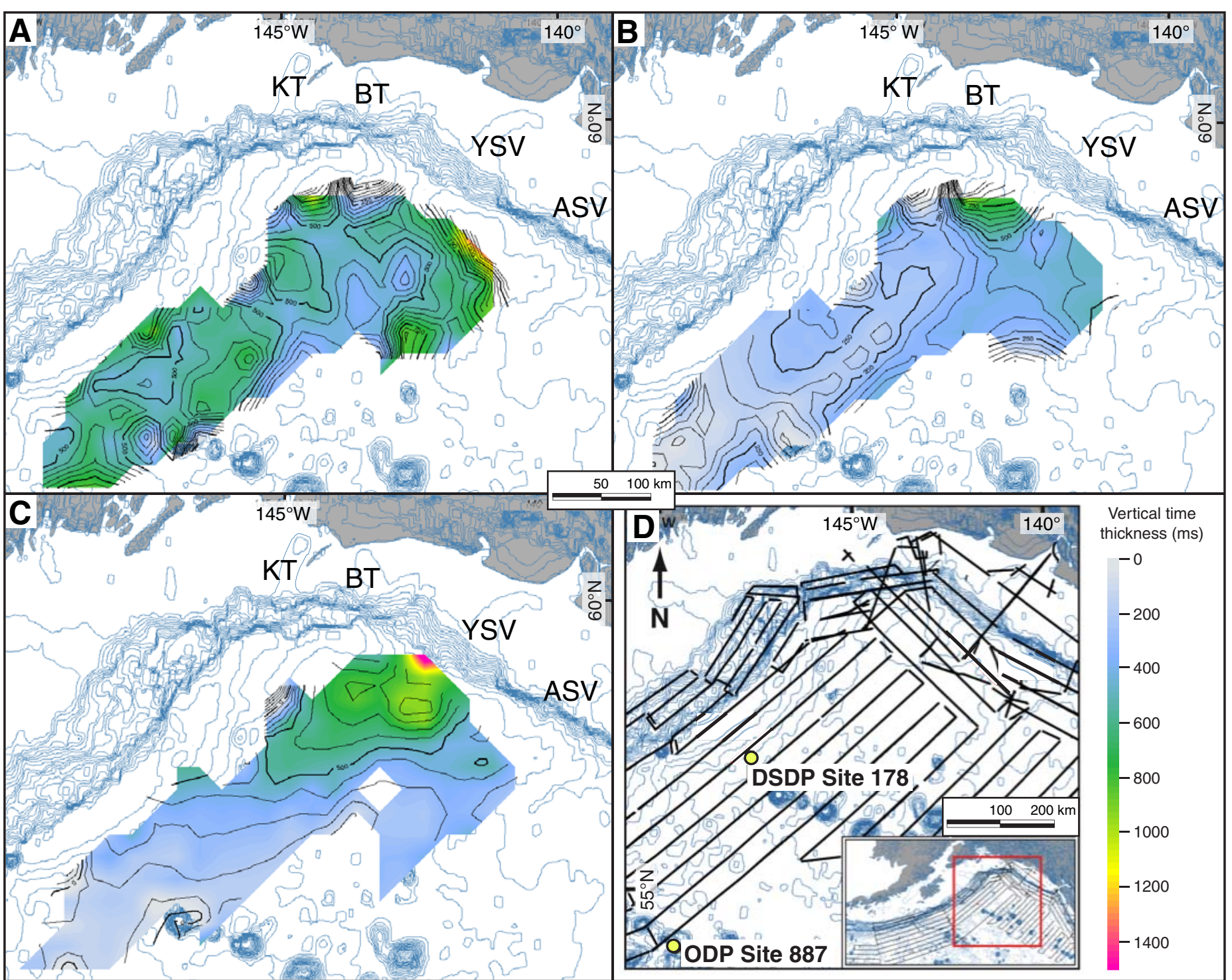



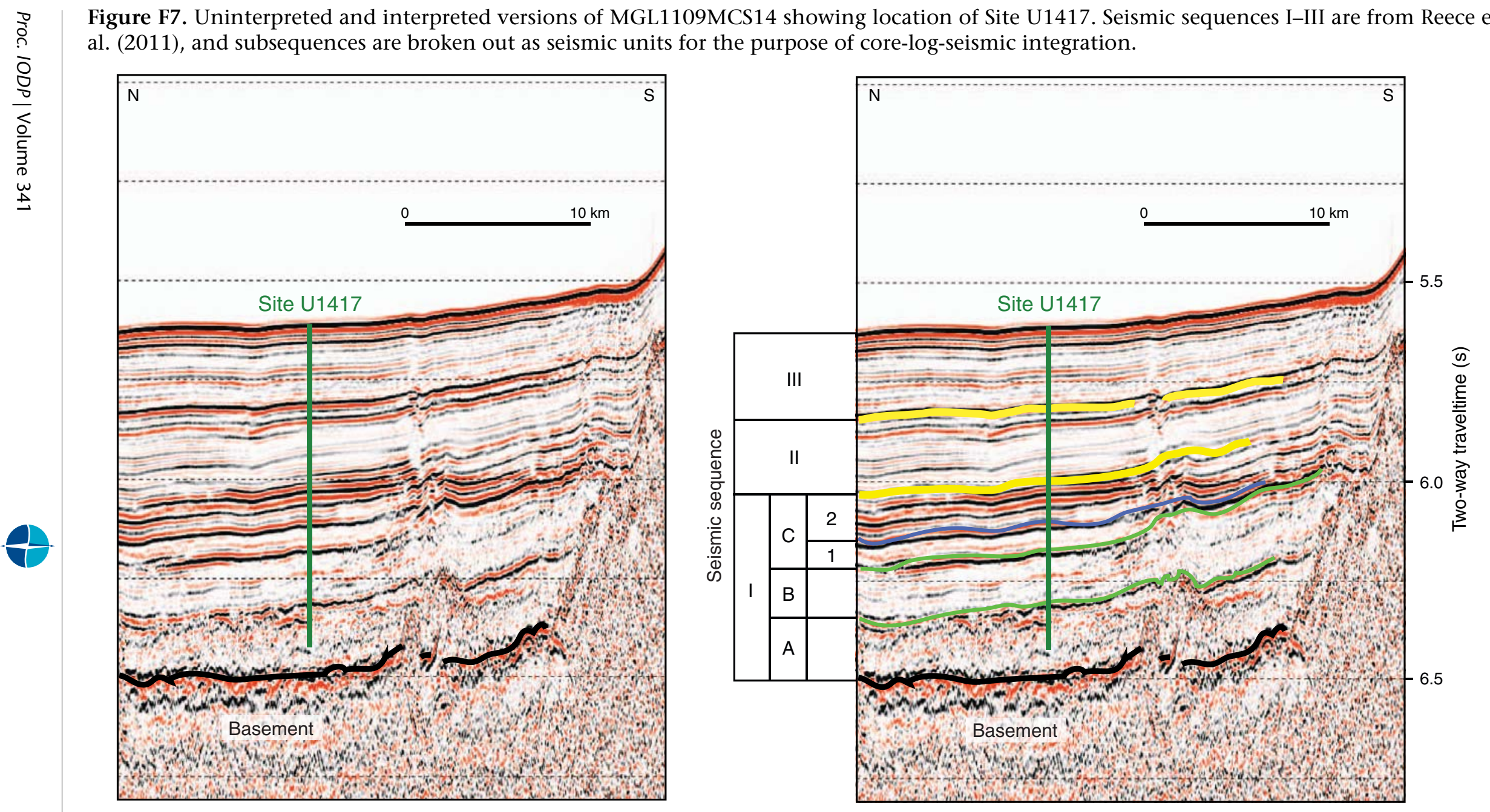
Figure F8. Stratigraphic, depositional, tectonic, and climatic history of the Gulf of Alaska (GoA) and adjacent regions, modified from Lagoe et al. (1993) and Berger et al. (2008a). Lithologic data from Lagoe et al. (1993), Rea and Snoeckx (1995), and Lagoe and Zellers (1996). Bedrock temperature paths vs. time from Berger et al. (2008a). Tectonic events from Lagoe et al. (1993), Stevenson and Embley (1987), Berger et al. (2008a, 2008b), Enkelmann et al. (2010), and Finzel et al. (2011). Oxygen isotope data from global stacks of Lisiecki and Raymo (2005) (black) and Zachos et al. (2001) (gray). IRD = ice-rafted debris. AHe = apatite $(\mathrm{U}-\mathrm{Th}) / \mathrm{He}, \mathrm{AFT}=$ apatite fission track, ZHe $=$ zircon $(\mathrm{U}-\mathrm{Th}) / \mathrm{He} . \mathrm{MPW}=\mathrm{mid}-\mathrm{Pliocene}$ warm period.

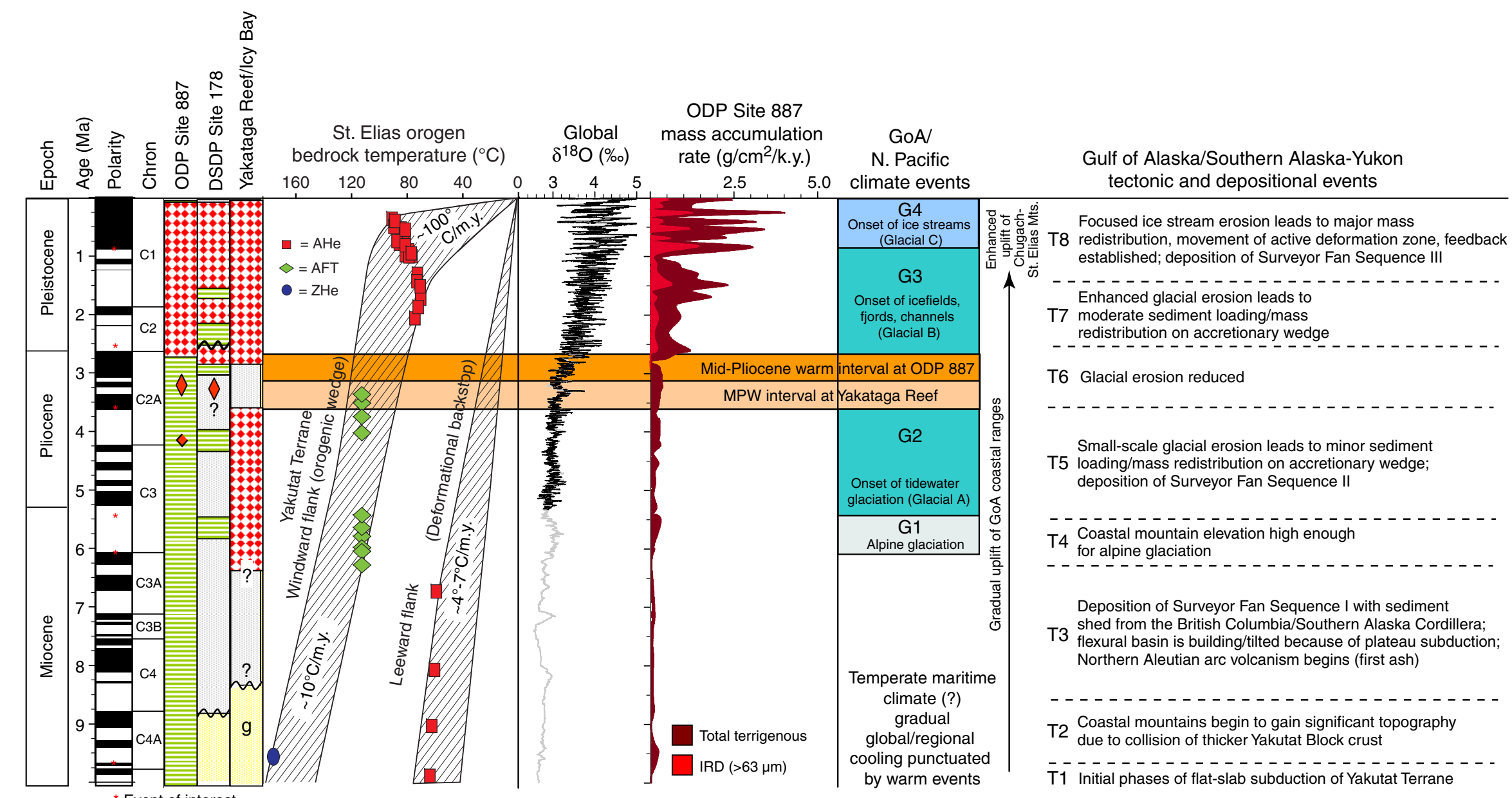


Figure F9. Core recovery, Site U1417.
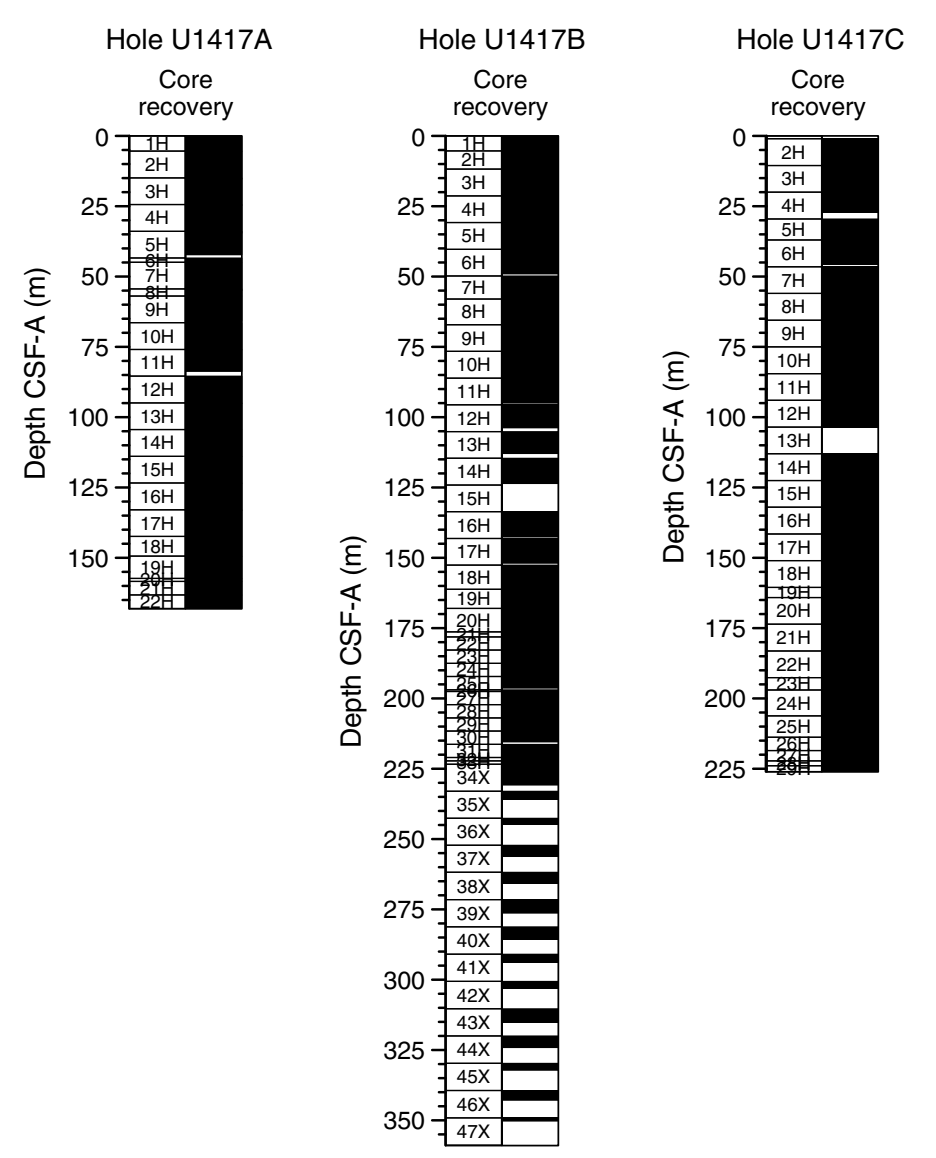

\section{Site U1417}
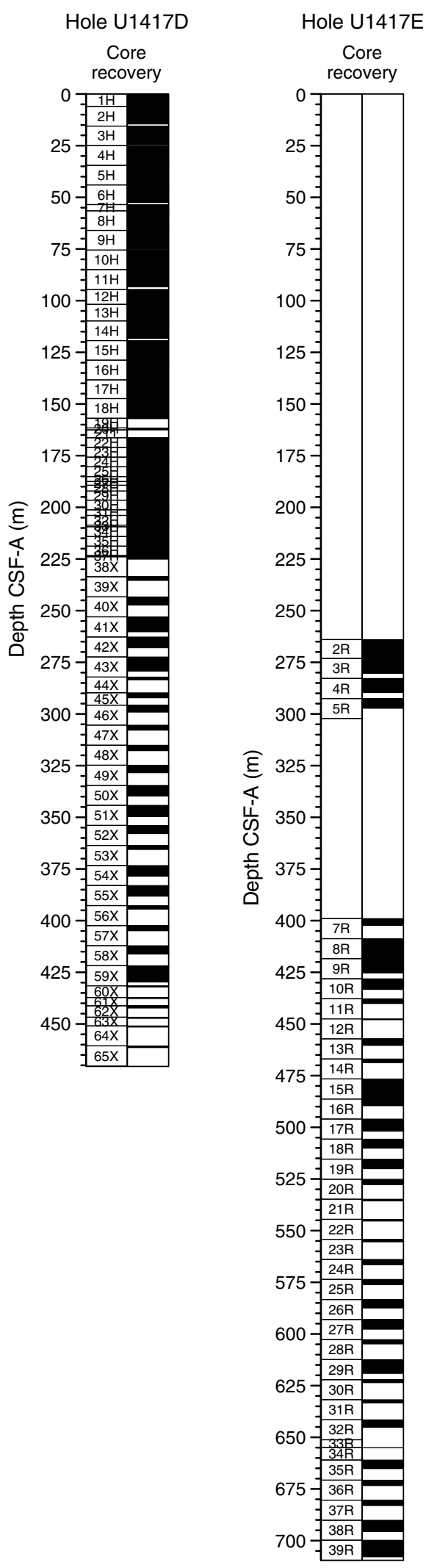
Figure F10. Hole summaries, Site U1417. Volcanic grain abundance: $1=$ trace, $2=$ volcaniclastic bearing, $3=$ volcaniclastic rich, $4=$ ash. GRA = gamma ray attenuation. A. Hole U1417A. (Continued on next four pages.)

A

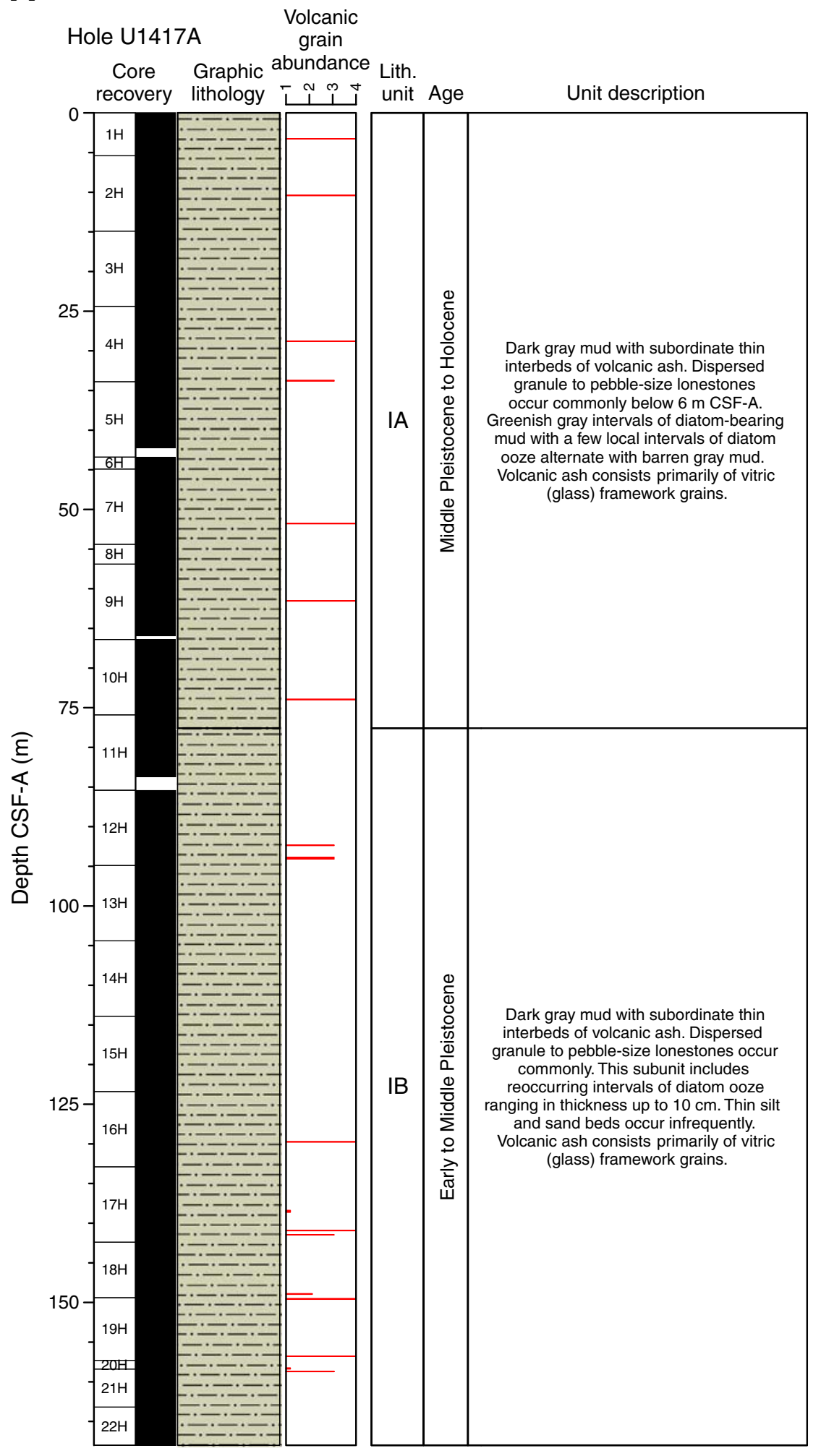

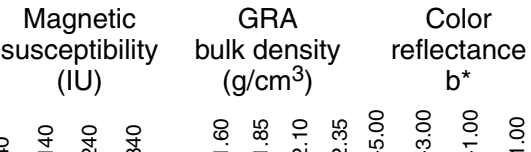

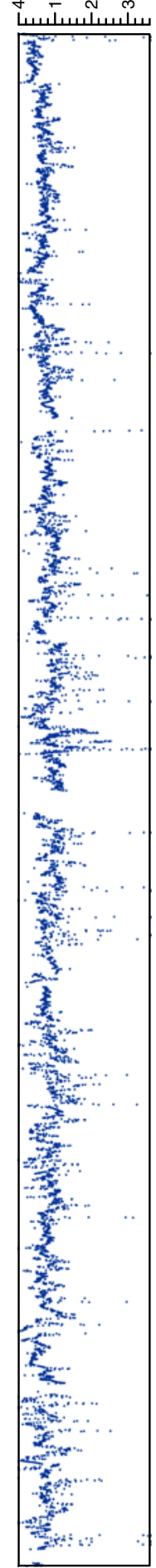

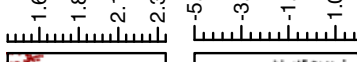
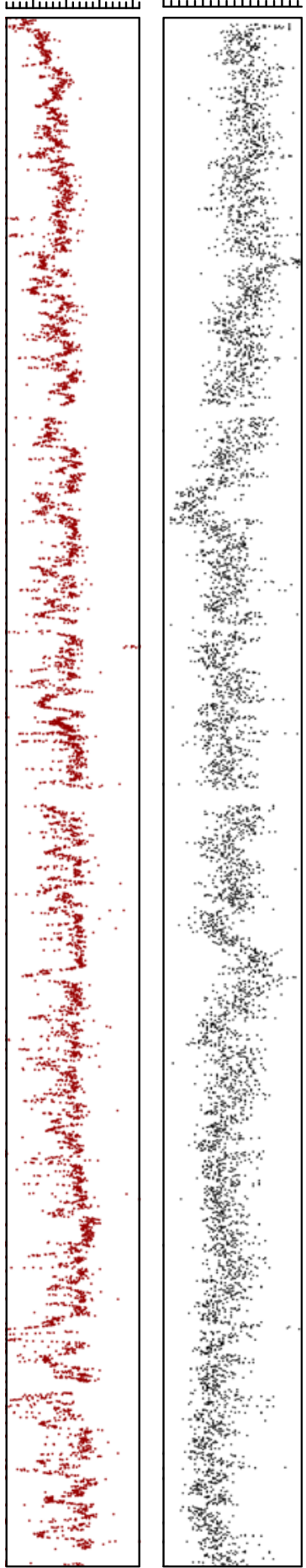
Figure F10 (continued). B. Hole U1417B. (Continued on next page.)

B

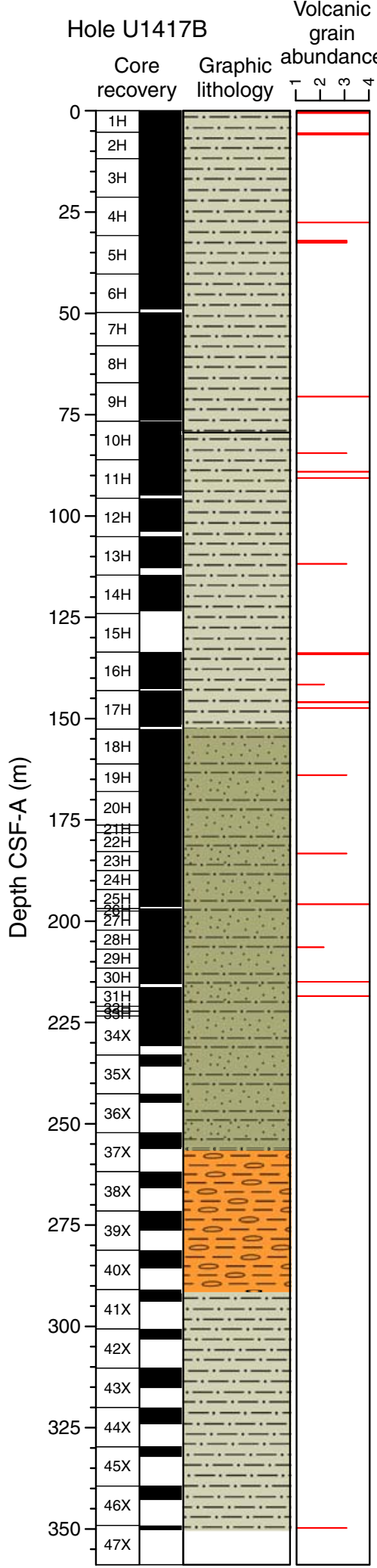

Lith.

unit Age

Unit description

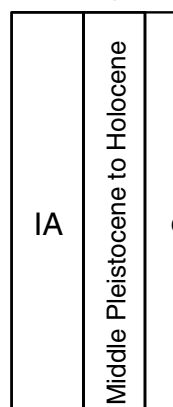

Dark gray mud with subordinate thin interbeds of volcanic ash. Dispersed granule to pebble-size lonestones Greenish gray intervals of diatom-bearing mud with a few local intervals of diatom barren gray mud. Volcanic ash consists primarily of vitric (glass) framework grains.

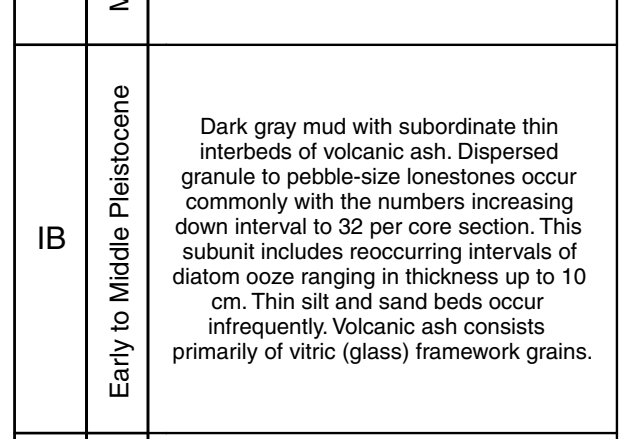

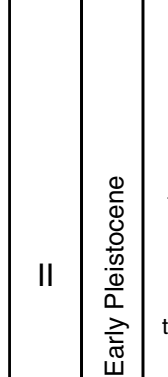

Gray to greenish-gray mud with distinct thin interbeds of fine sand and coarse silt. Sand/silt beds commonly have sharp lower contacts and are massive to normally graded. Sand beds are typically less than $5 \mathrm{~cm}$ thick. Relative to Unit 1 , this unit has a decrease in lonestones, and in the frequency of occurrence of volcanic ash, and diatom-rich intervals.

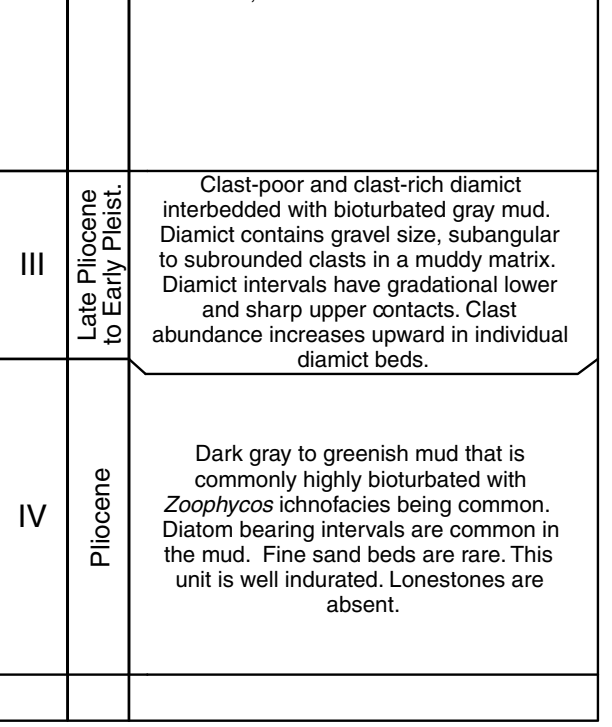

\section{Magnetic susceptibility}

(IU)

GRA
bulk density

$\left(\mathrm{g} / \mathrm{cm}^{3}\right)$

Color

아원 운 웅

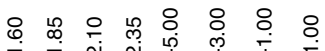

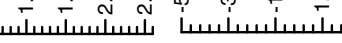
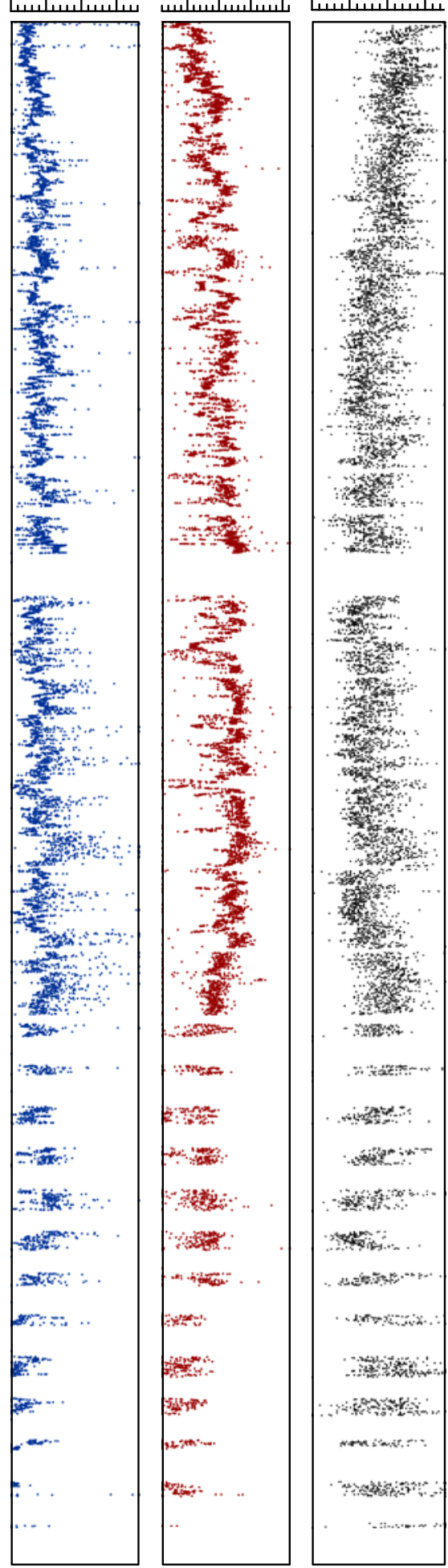
Figure F10 (continued). C. Hole U1417C. (Continued on next page.)

C

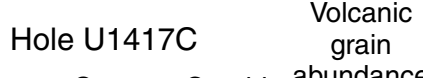

Core Graphic abundance Lith

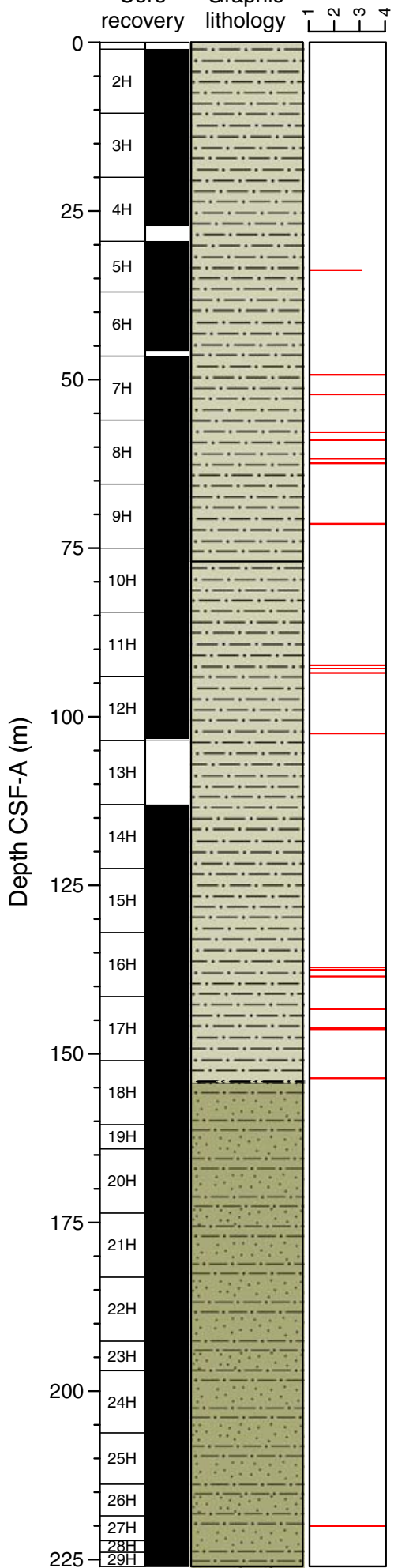

Unit description

it Age

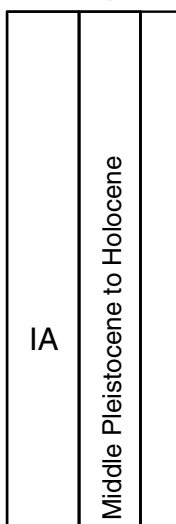

Dark gray mud with subordinate thin interbeds of volcanic ash. Dispersed granule to pebble-size lonestones occur commonly below $5 \mathrm{~m}$ CSF-A. Greenish gray diatom-bearing mud with local intervals of diatom ooze alternates with barren gray mud. Volcanic ash consists primarily of vitric (glass) framework grains.

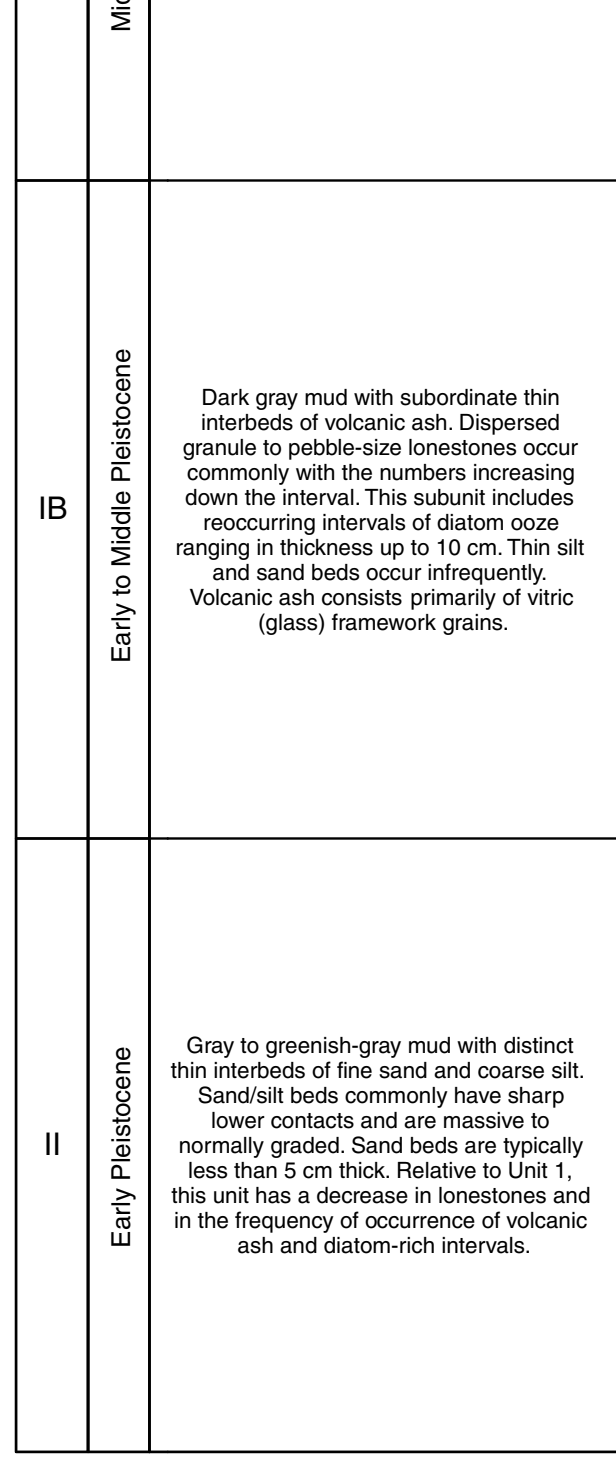

\section{Magnetic susceptibility}

(IU)

GRA
bulk density
$\left(\mathrm{g} / \mathrm{cm}^{3}\right)$

Color

앙 운 웅 reflectance ○ سلسلسلسا
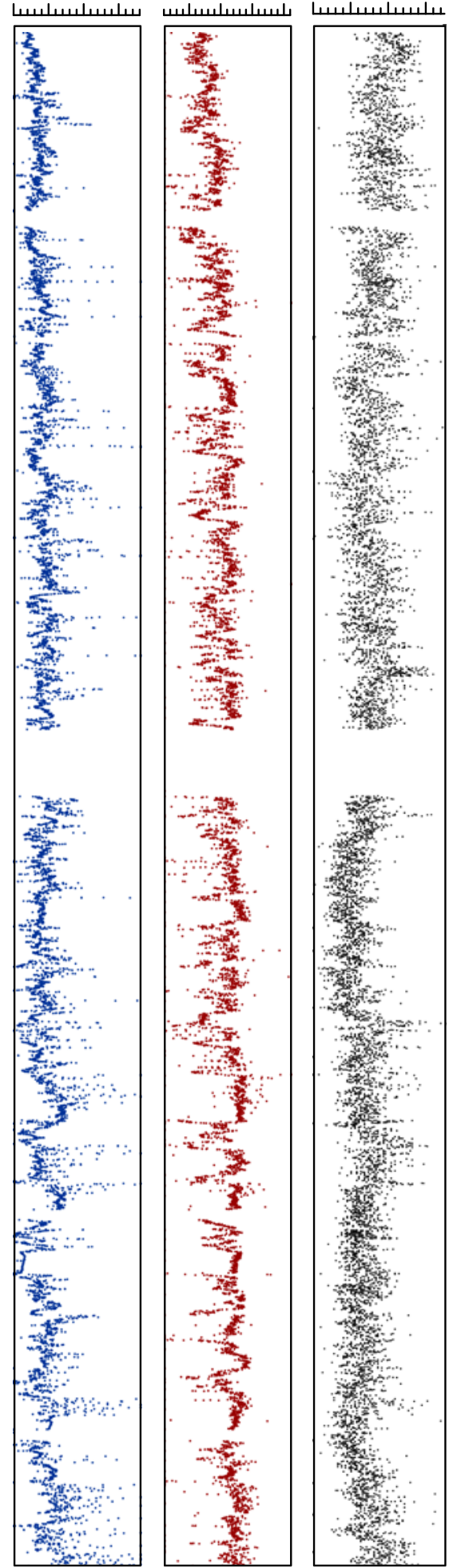
Figure F10 (continued). D. Hole U1417D. (Continued on next page.)

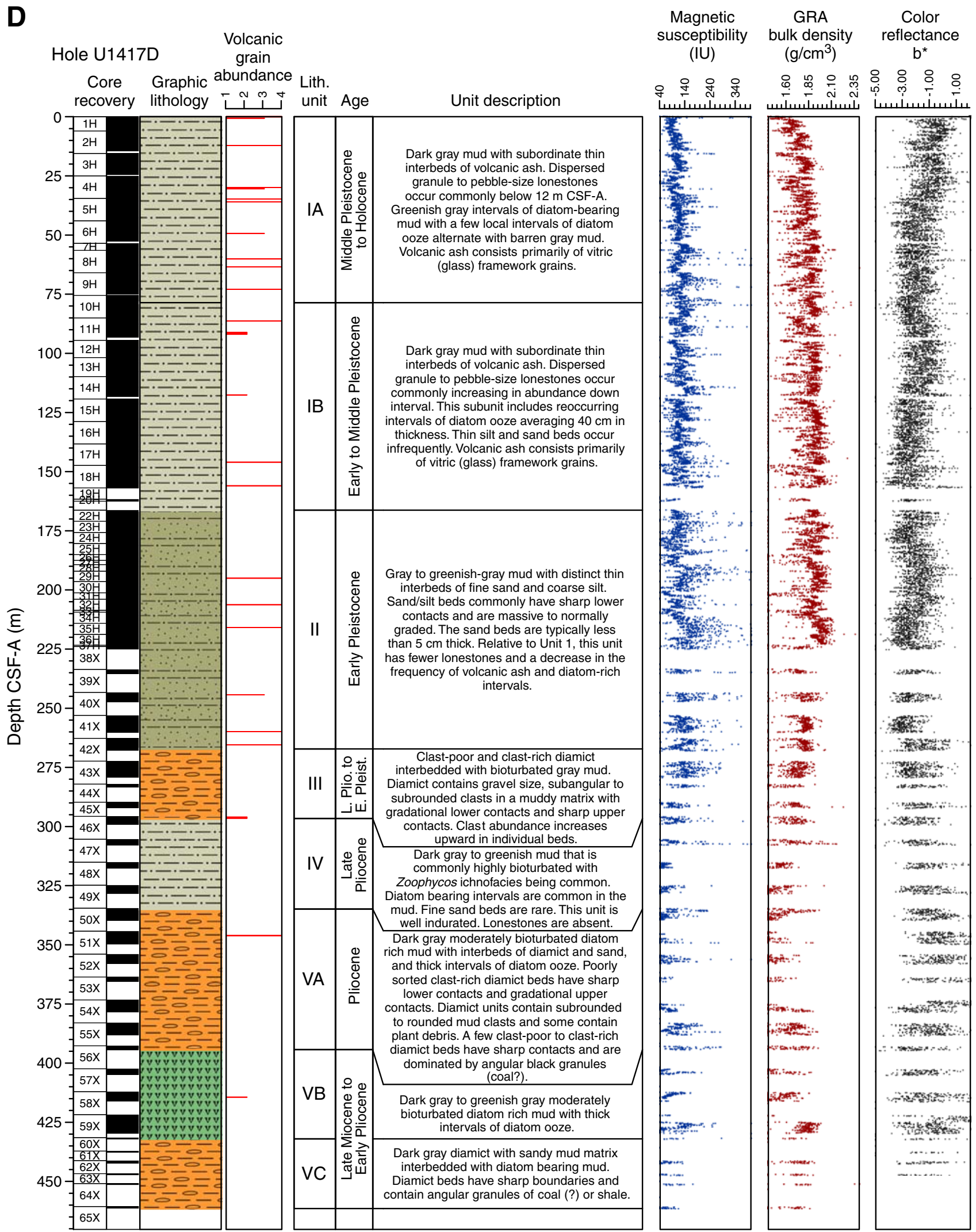


Figure F10 (continued). E. Hole U1417E.

E

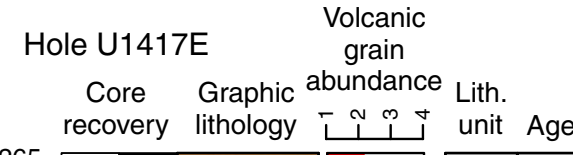

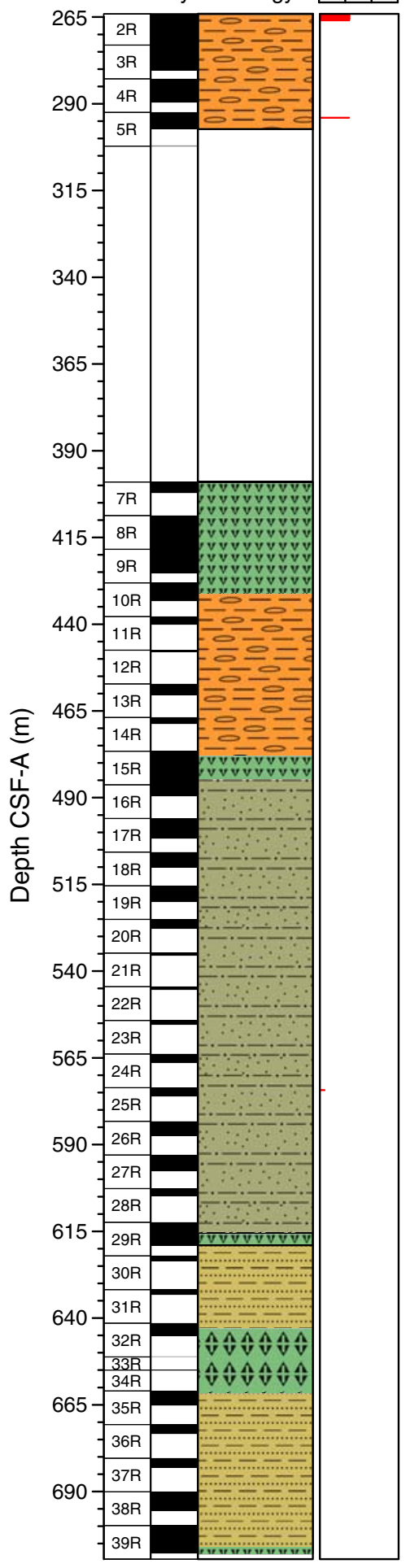

Unit description

\begin{tabular}{|c|c|c|}
\hline II & 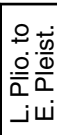 & $\begin{array}{l}\text { Dark gray clast-poor and clast-rich diamict } \\
\text { interbedded with bioturbated gray mud. } \\
\text { Diamict units contain gravel size, subangular to } \\
\text { subrounded clasts in a mudddy matrix. Diamict } \\
\text { beds have gradational lower contacts and }\end{array}$ \\
\hline
\end{tabular}

Drilled interval - no cores collected

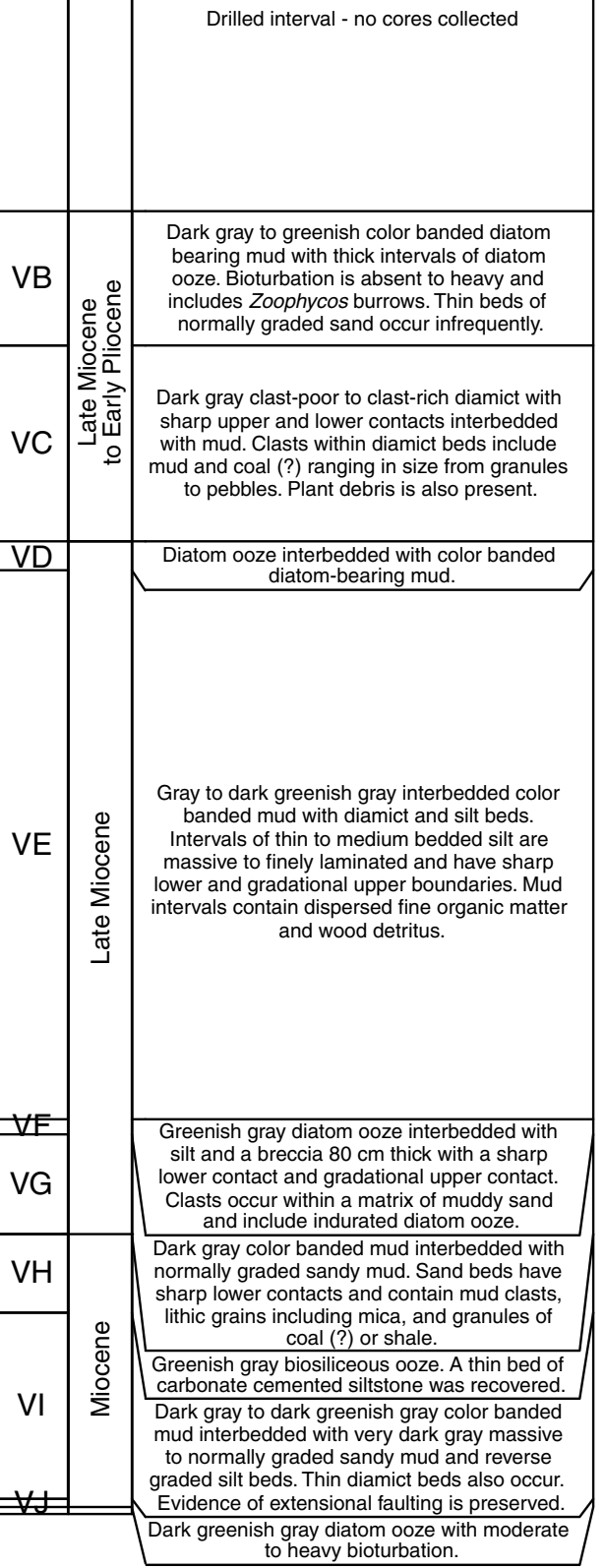

Magnetic susceptibility

(IU)

응 웅 웅

لسسلسسلسنسانسا

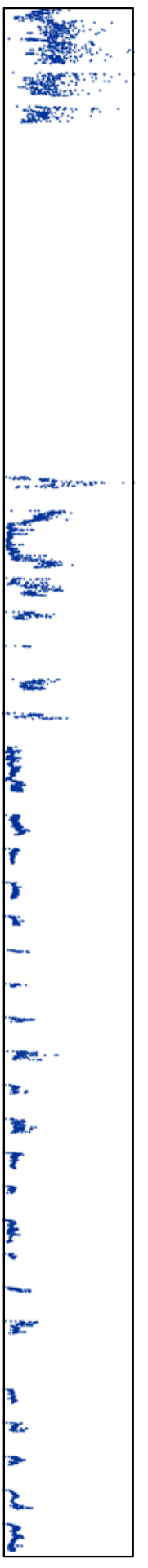

GRA bulk density

$\left(\mathrm{g} / \mathrm{cm}^{3}\right)$

Color reflectance

$b^{*}$

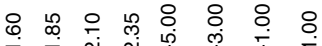
$\tau$ -

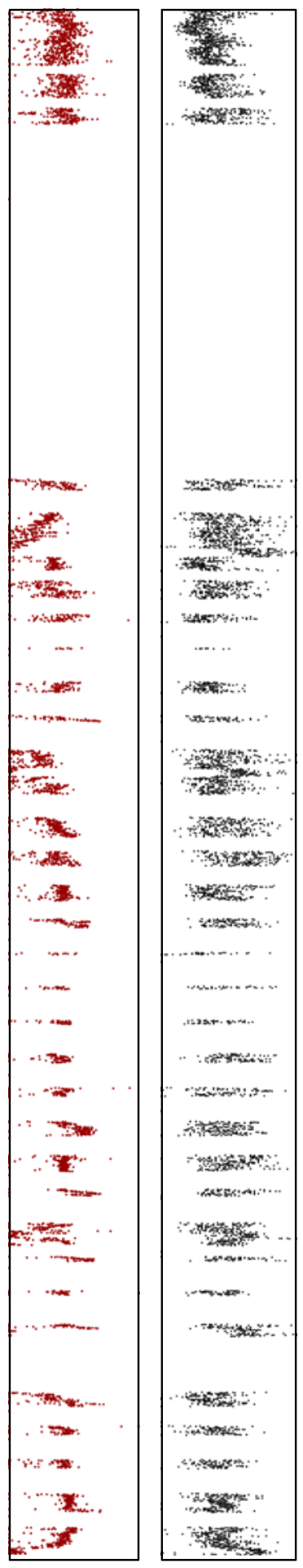


Figure F11. Primary lithologies of Site U1417. A. Dark gray (N 4) mud (Facies F1b; interval 341-U1417D-3H$3 \mathrm{~A}, 93-100 \mathrm{~cm}$ ). B. Interbedded sand and mud; sand is normally graded (Facies F3c; interval 341-U1417C-17H6A, 80-96 cm). C. Muddy diamict with upward increasing abundance of subangular to subrounded clasts (Facies F4a; interval 341-U1417B-38X-1A, 56-66 cm). Note the gradational lower and sharp upper contacts. D. Muddy and sandy diamict with abundant mud rip-up clasts (Facies F4b; interval 341-U1417D-52X-3A, 4-11 $\mathrm{cm}$ ). E. Muddy and sandy diamict with abundant dark coal clasts (Facies F4b; interval 341-U1417D-64X-1A, $40-47 \mathrm{~cm}$ ). Note that the diamict grades upward into coarse sand of Facies F3b. F. Muddy and sandy diamict with dark organic components and lighter-colored mud clasts (Facies F4b; interval 341-U1417E-39R-1A, 43-52 cm). G. Bioturbated diatom ooze with Zoophycos burrows (Facies F5a; interval 341-U1417D-57X-1A, 69-77 cm). The ooze is the lighter colored greenish lithology in the center of the photo. H. Color-banded and bioturbated diatom ooze (Facies F5a; interval 341-U1417E-29R-2A, 12-38 cm).

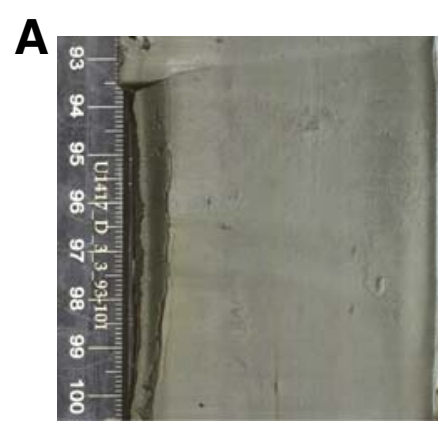

B

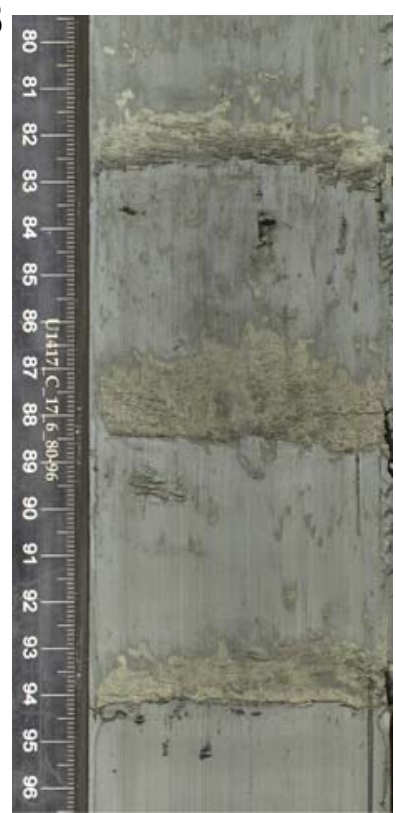

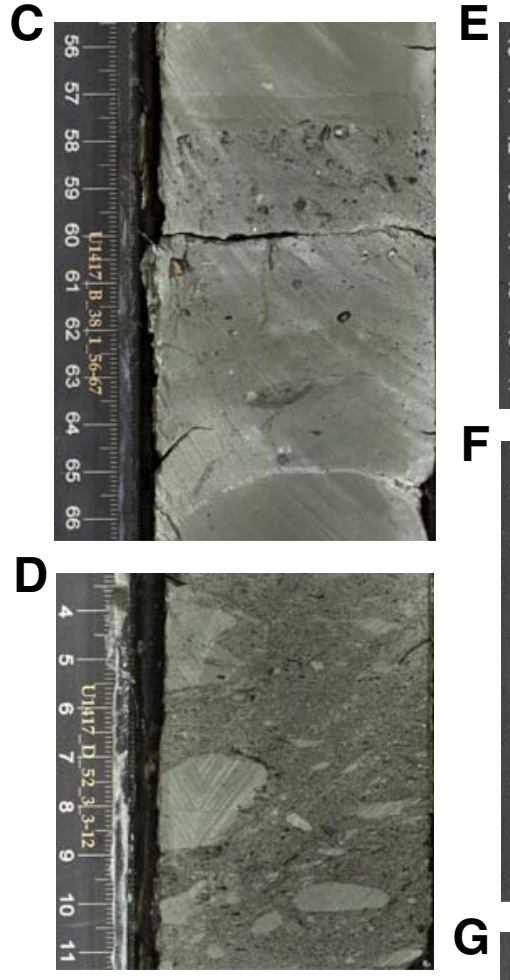
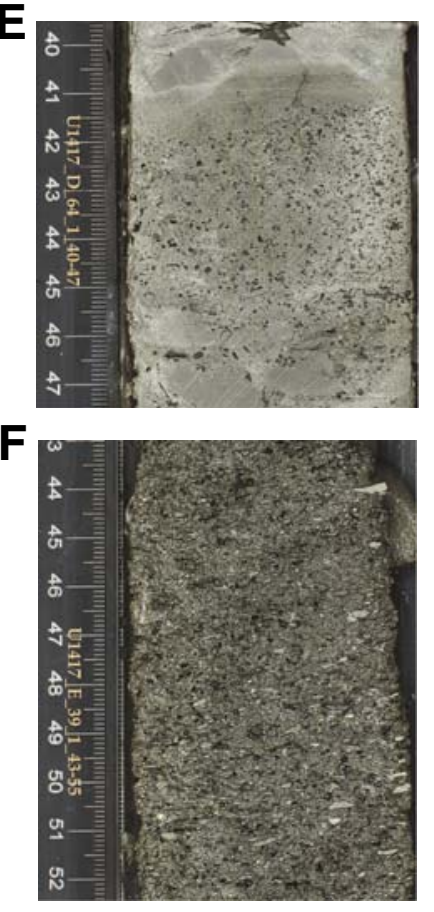

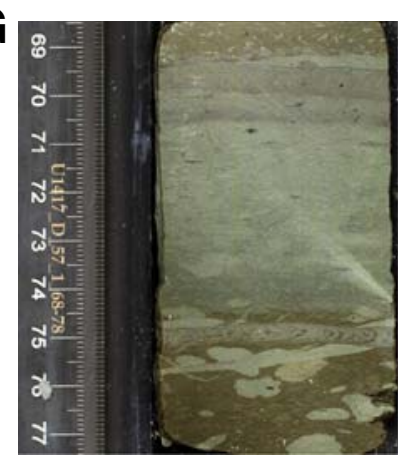

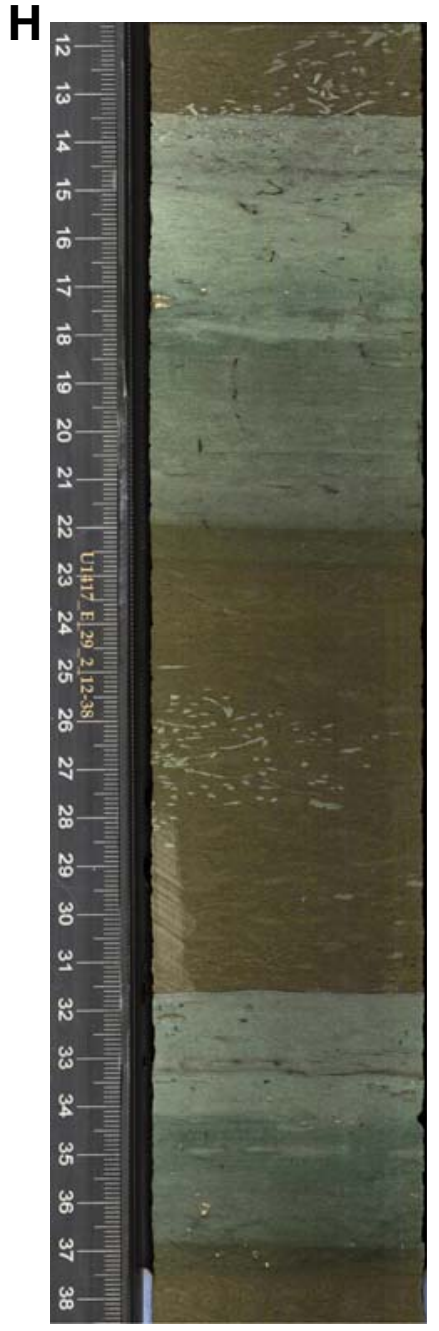


Figure F12. Lonestones and sedimentary and deformational structures, Site U1417. A. Argillite lonestone (interval 341-U1417B-27H-1A, 1-4 cm). B. Sandstone lonestone (interval 341-U1417C-24H-6A, 12-18 cm). C. Metabasalt lonestone (interval 341-U1417C-6H-3A, 58-64 cm). D. Granite lonestone (interval 341-U1417C-7H5A, 41-43 cm). E. Load casts at base of normally graded sand (Facies F3a; interval 341-U1417C-20H-2A, 133$136 \mathrm{~cm}$ ). F. Normal faults in diatom ooze (interval 341-U1417E-36R-2A, 18-23 cm). G. Woody fragment at base of a muddy and sandy diamict (Facies F4b; interval 341-U1417E-31R-1A, 40-41 cm). H. Microscope image of woody fragment encountered in a smear slide (interval 341-U1417D-60X-CC). I. Scanning electron microscope image of woody fragment (interval 341-U1417D-51X-3A, $74 \mathrm{~cm}$ ). J. Detail of woody fragment shown in I. K. Pyritized worm tube (interval 341-U1417C-15H-1A, $46 \mathrm{~cm}$ ).
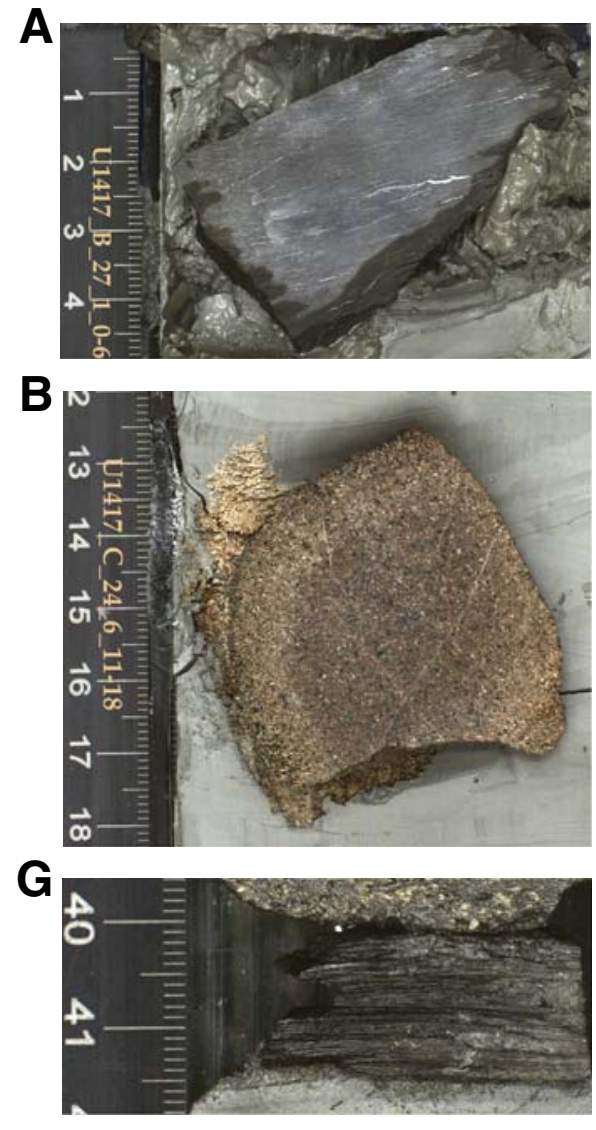

$\mathbf{H}$

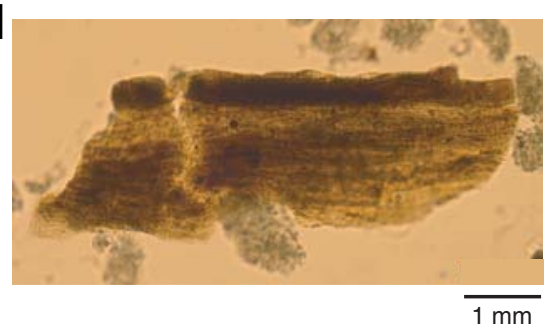

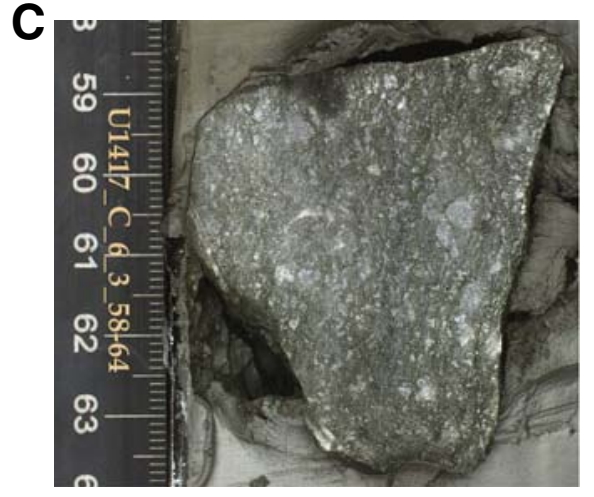
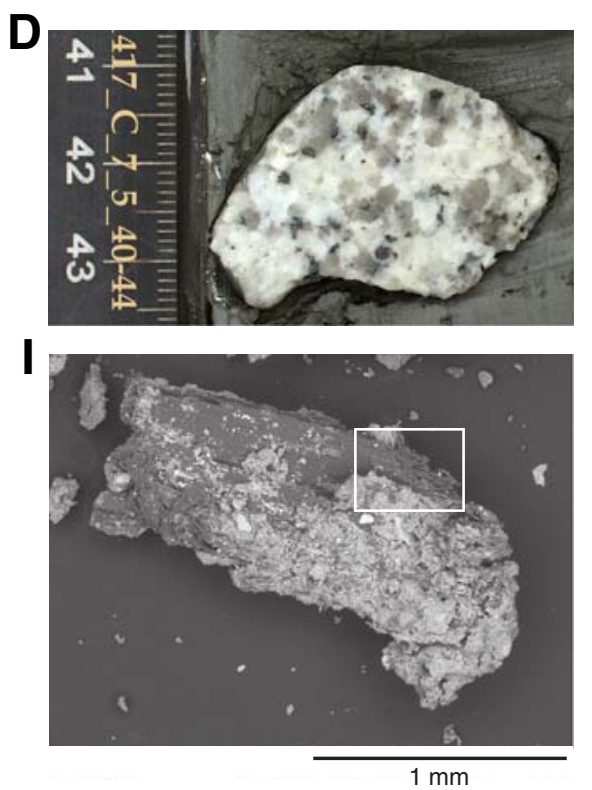

K
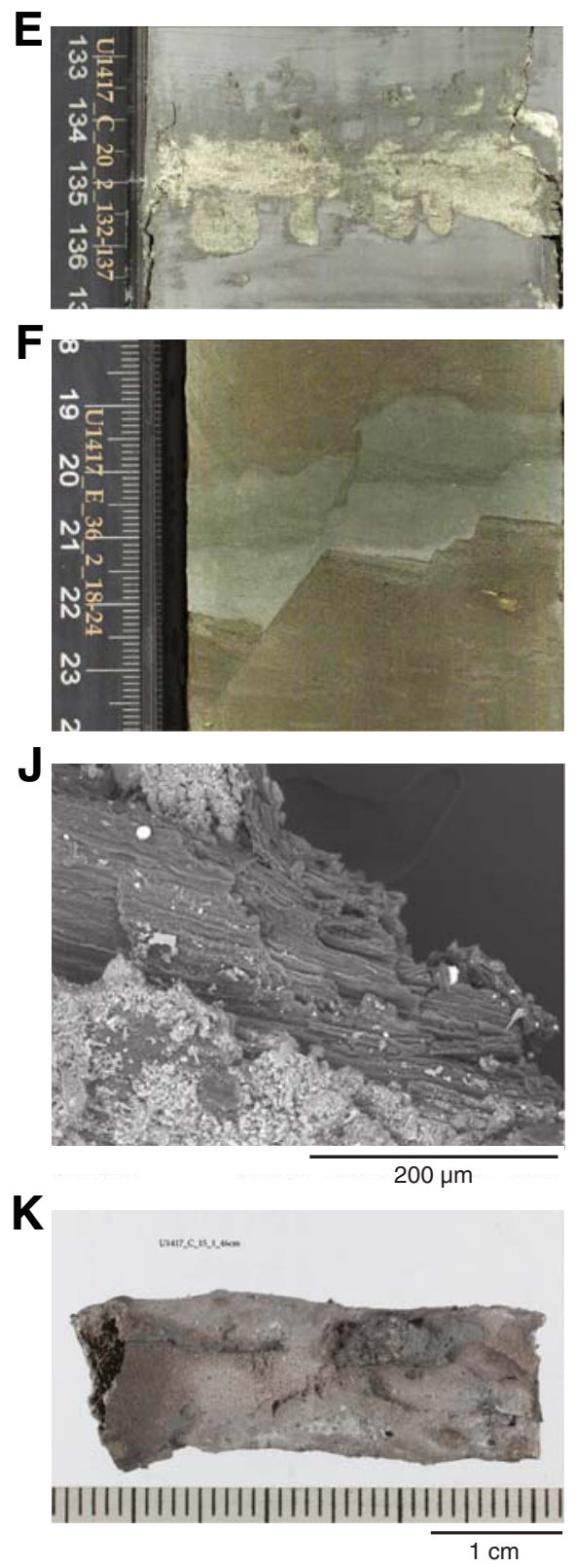
Figure F13. Ash images, Site U1417. A-C. Glassy ash containing 5\% lithic grains (interval 341-U1417D-8H-5, 94-97 cm; (A) core, (B) smear slide, (C) detail of scanning electron microscope image. D. Well-sorted siltbearing glassy ash (interval 341-U1417A-17H-6, 48-55 cm). E, F. Highly bioturbated mud with glassy ash lenses (interval 341-U1417D-51X-2, 35-38 cm); (E) core, (F) smear slide. Ash is the lighter colored lithology. Note diatom fossil in lower center of $\mathrm{F}$.
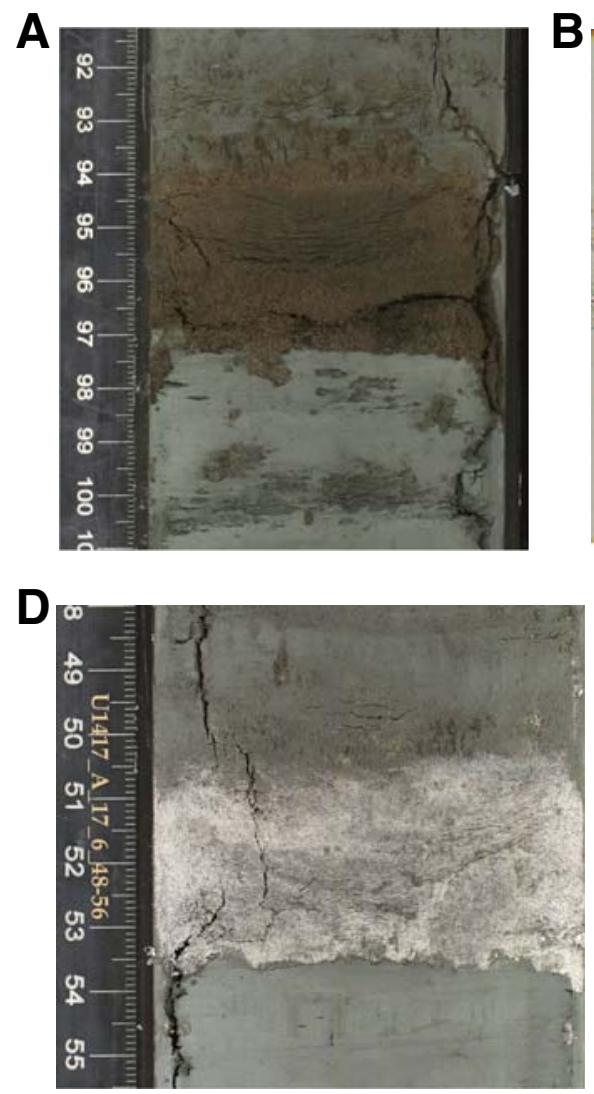
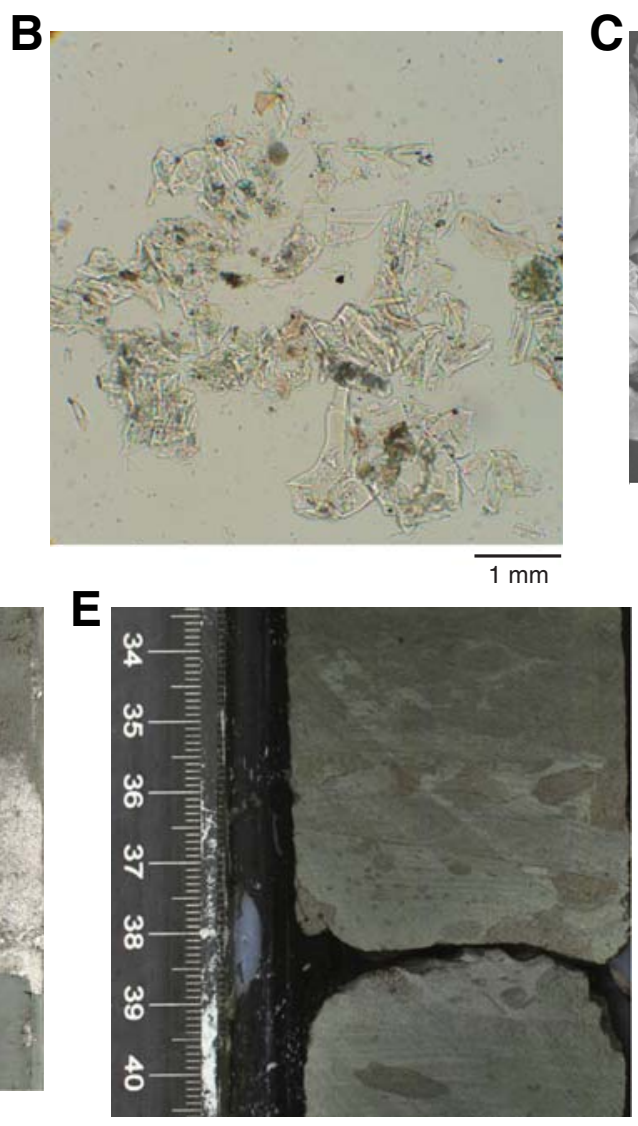
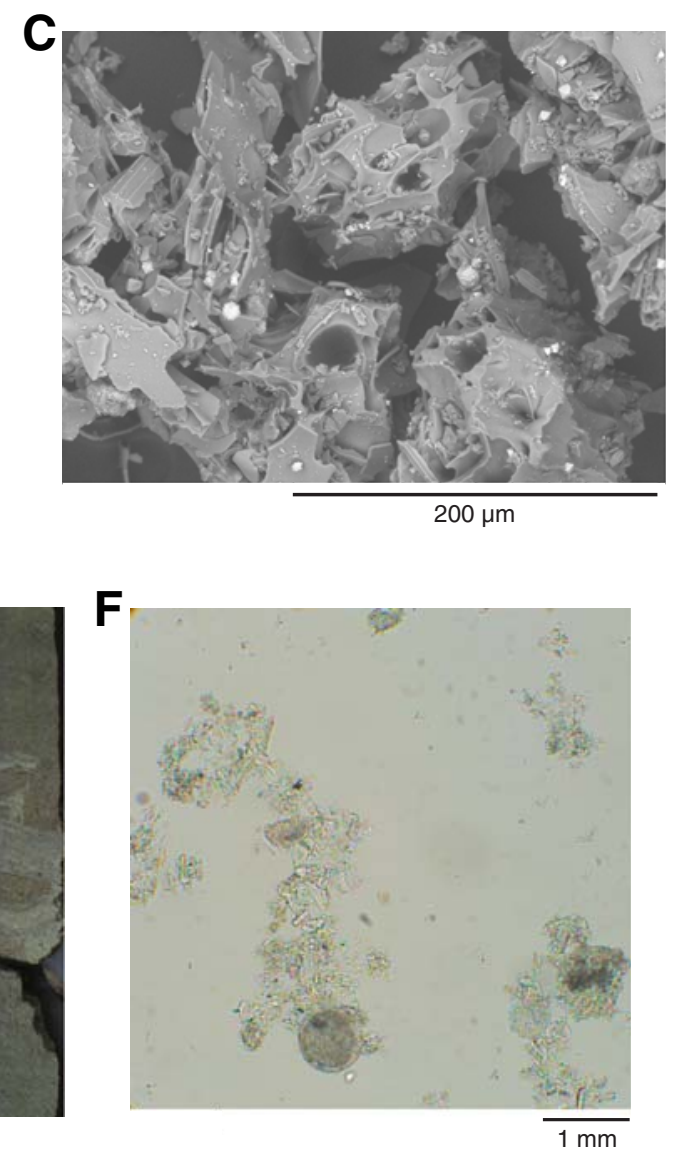
Figure F14. A. X-ray powder diffraction patterns, Holes U1417A-U1417E. Bulk mineralogy is nearly constant downhole, although minor changes in relative peak intensities occur. (Continued on next page.)

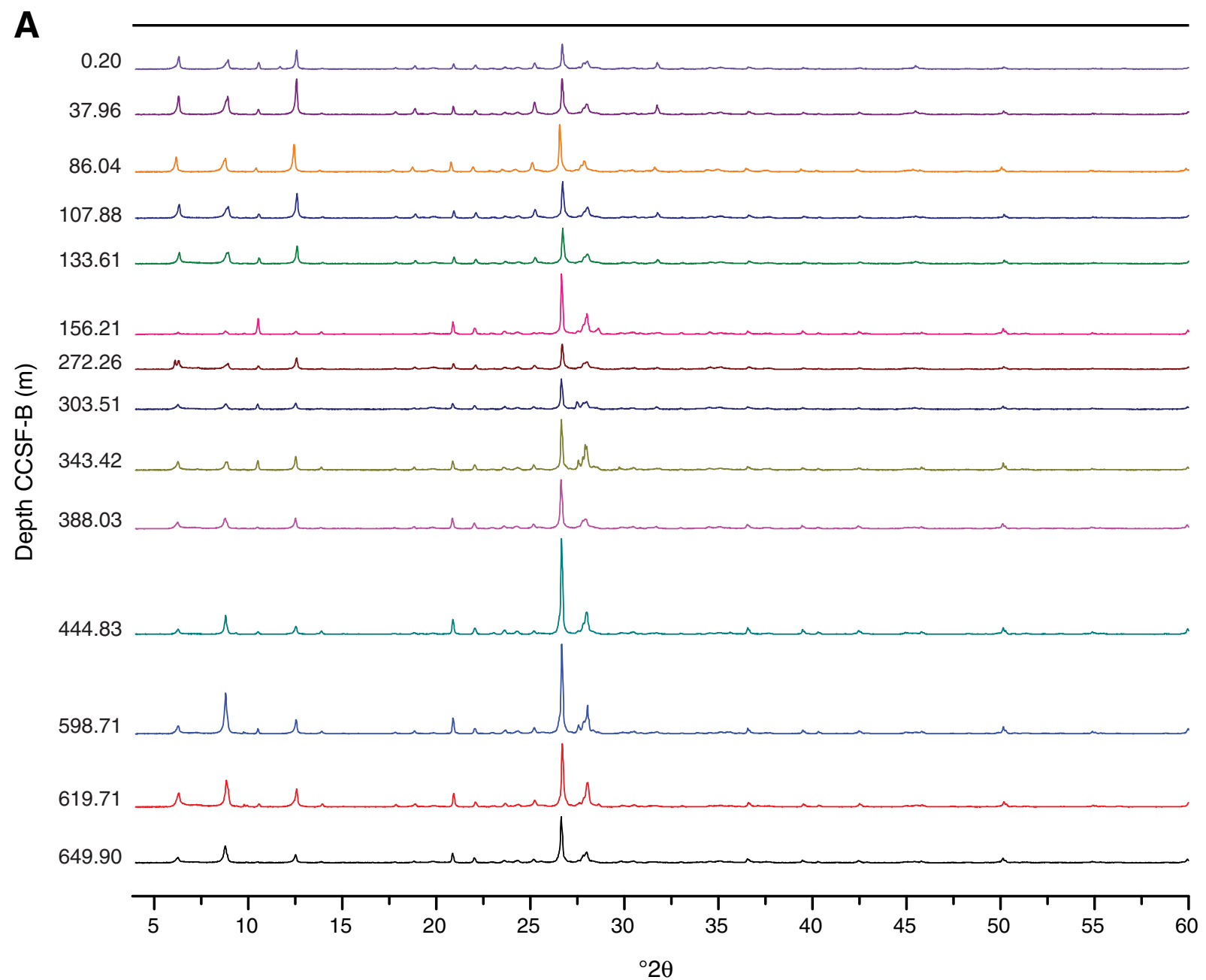


Figure F14 (continued). B. Comparative X-ray diffraction patterns from $4^{\circ}$ to $24^{\circ} 2 \theta$, Site U1417. Scans show downhole samples before (left) and after (right) treatment with glycolate to assess the presence of expandable clay minerals.

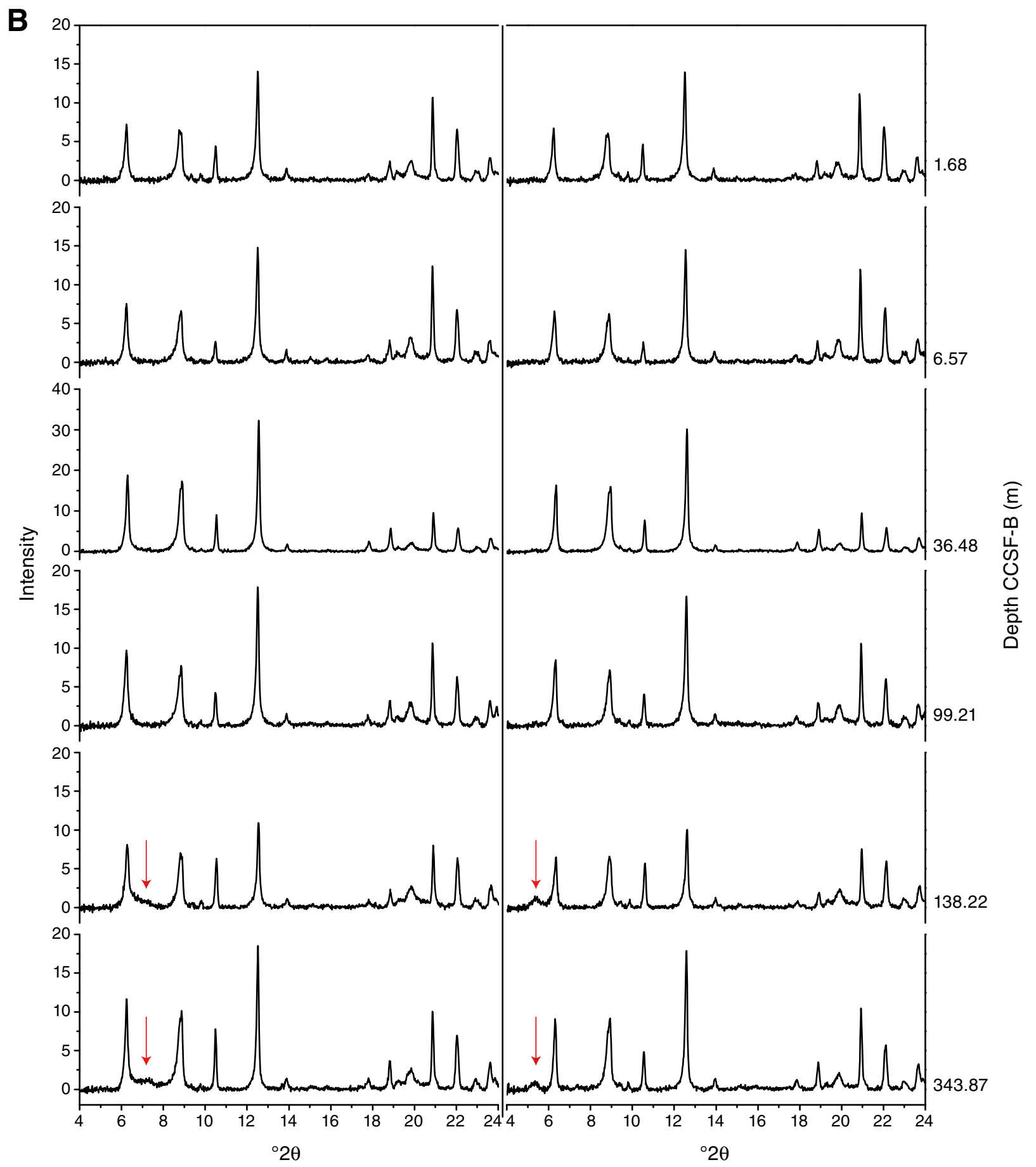


Figure F15. Diagram illustrating common relationships between lithology, clast count, and physical properties at the lithostratigraphic Subunit IB-Unit II transition (Sections 341-U1417C-17H-3A through 18H-1A). Decreases in magnetic susceptibility, gamma ray attenuation (GRA) bulk density, and natural gamma radiation, combined with increases in color reflectance index, highlight the location of diatom ooze. Mafic-rich sand corresponds to an increase in magnetic susceptibility, whereas volcanic ash dominated by glass shards shows no change in magnetic susceptibility. Photomicrographs of smear slides to right of the figure illustrate major lithologies present over specific intervals.

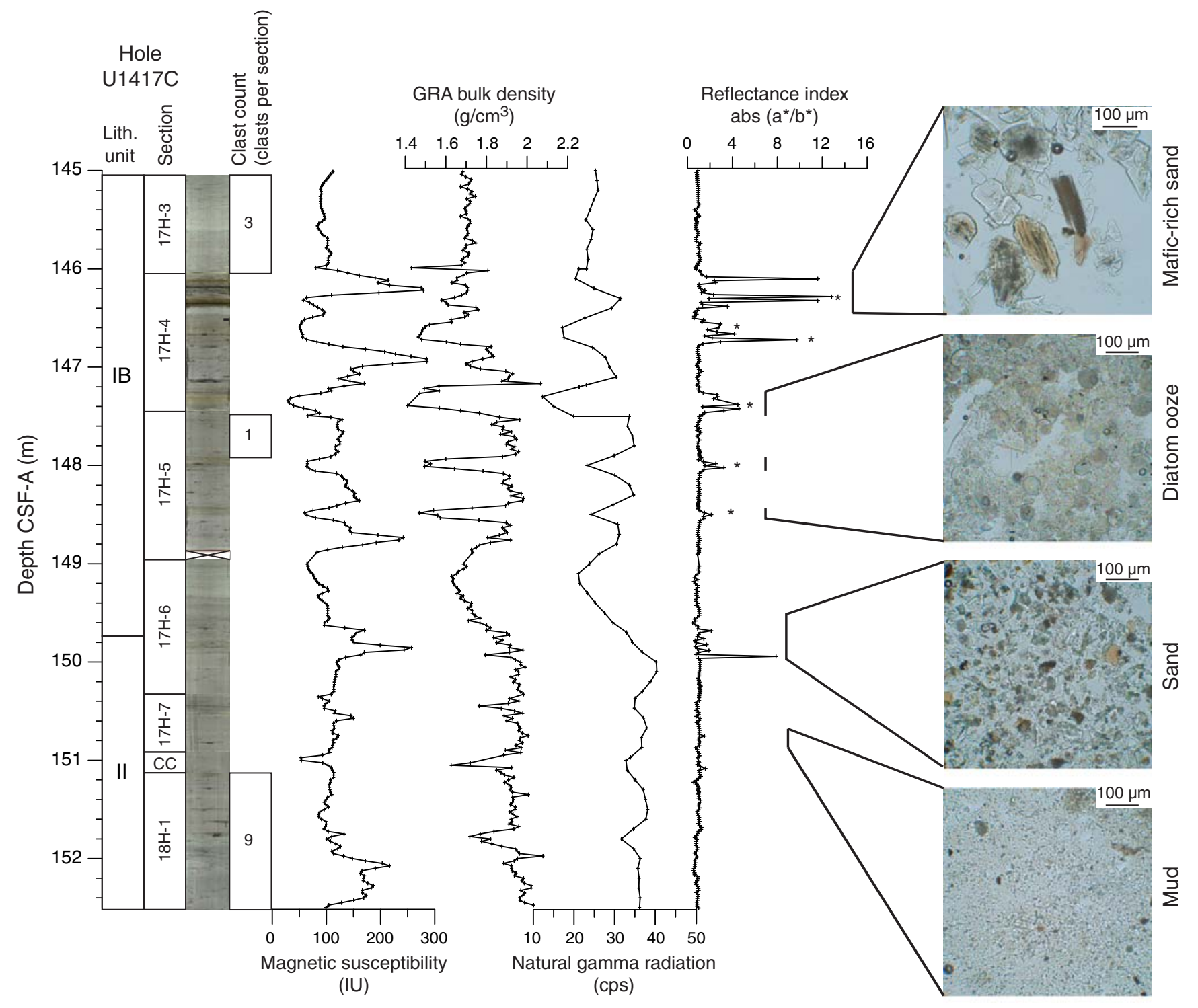


Figure F16. Schematic diagram of lithostratigraphic units and major lithologies using combined data from Holes U1417A-U1417E. Lonestone counts are the number of clasts $>2 \mathrm{~mm}$ diameter per meter of described section. Diamict includes both ice-rafted and gravity flow interpretations. With the exception of lonestone counts, downcore profiles show the middepth location of each feature/intervals in the overall sedimentary sequence. Solid lines $=$ Neogene epoch boundaries that coincide with or are within $10 \mathrm{~m}$ of a measured paleomagnetic reversal. Dashed lines $=$ uncertain locations of epoch boundaries estimated from the shipboard age model.

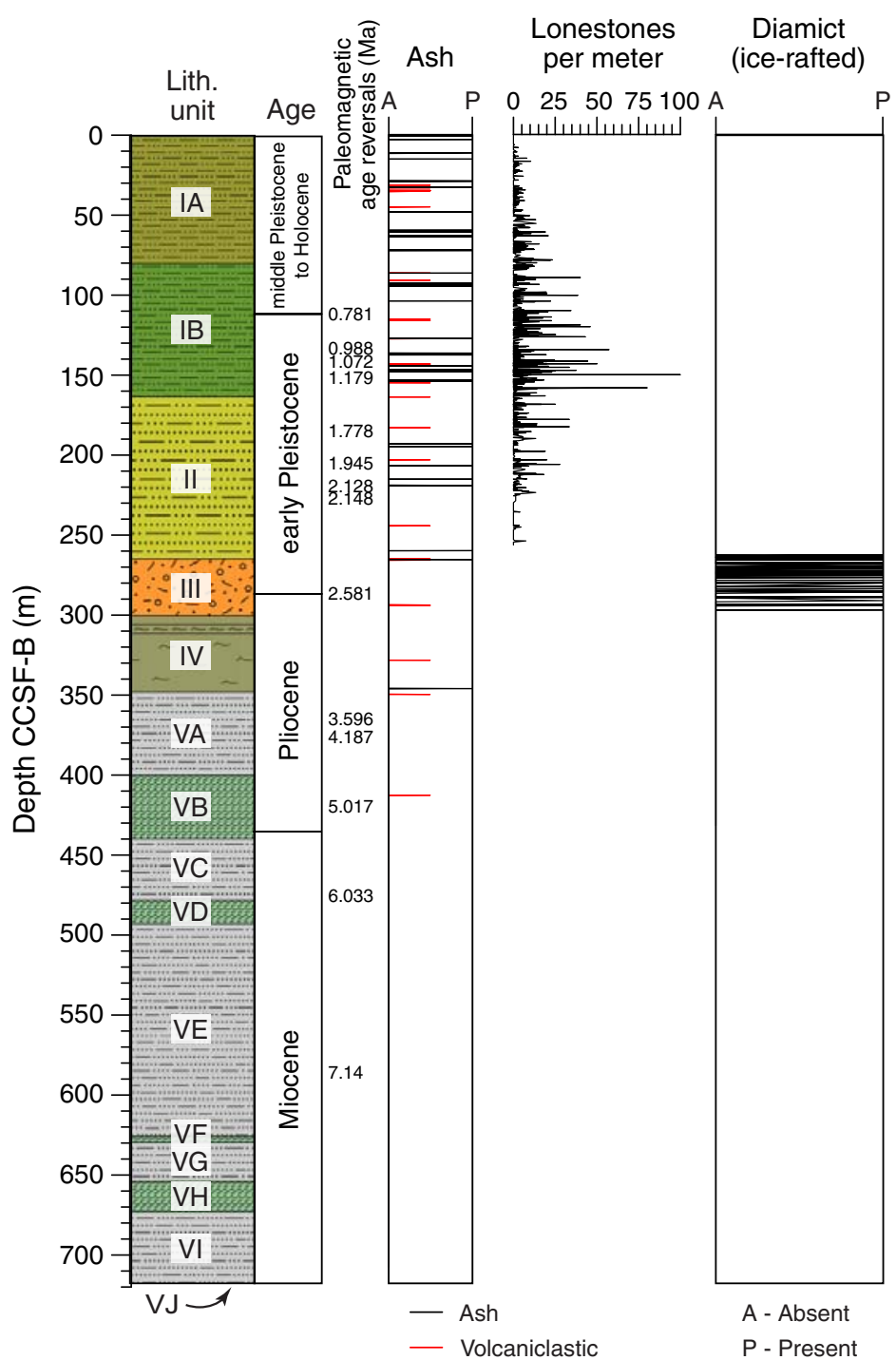

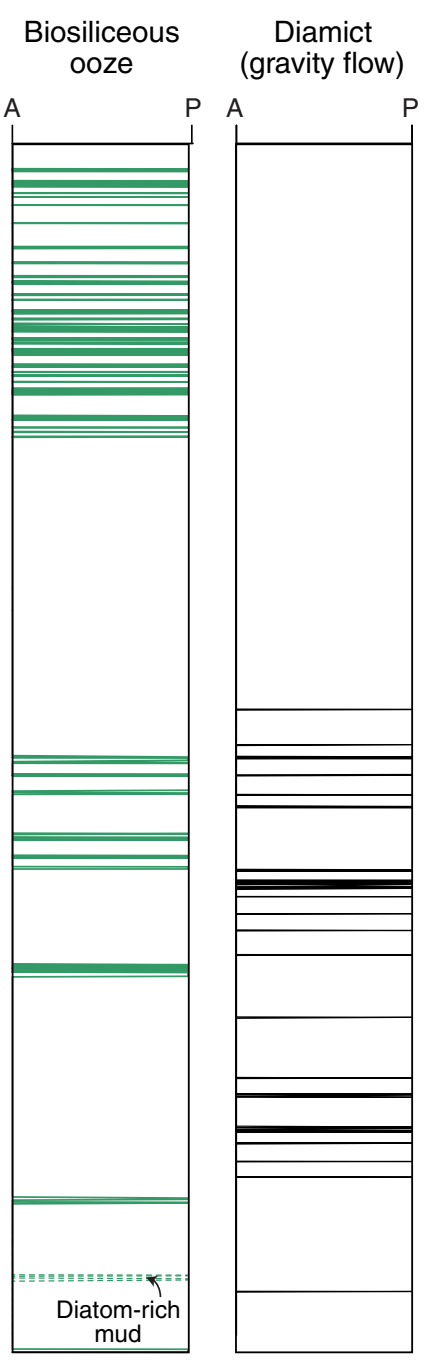

P - Present

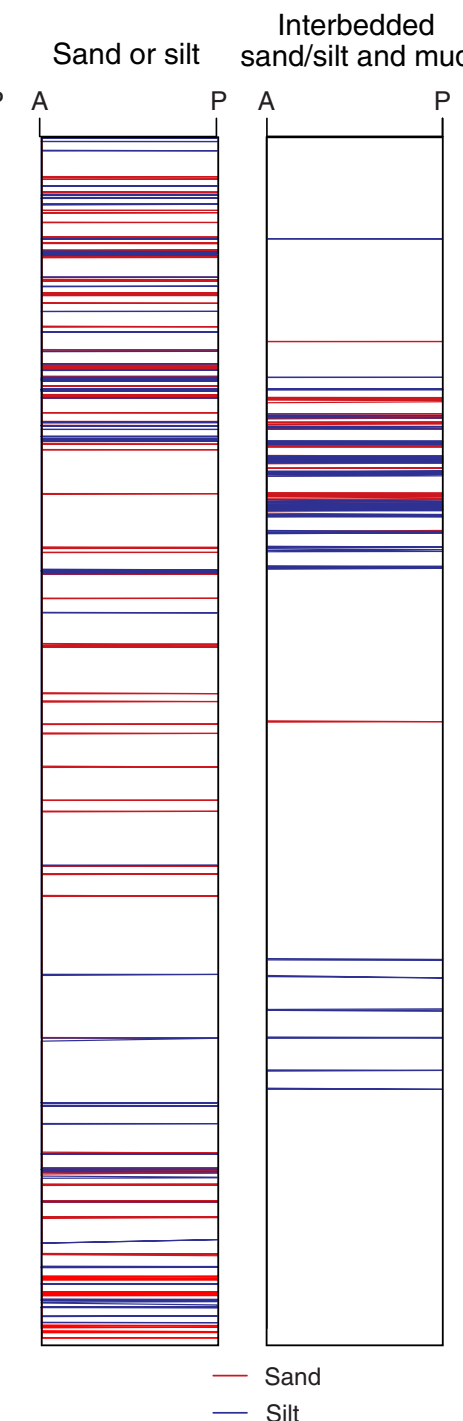

Dark gray mud; lonestones and intervals of diatom ooze occur locally Dark gray to greenish mud that is commonly highly bioturbated with Zoophycos ichnofacies

Dark gray mud; lonestones and intervals of diatom ooze are common Dark gray to greenish gray

:.: color-banded mud containing intervals of diamict and silt beds

Gray to greenish gray mud with distinct thin interbeds of sand and silt

Greenish gray biosiliceous ooze interbedded with color-banded mud

Diamict interbedded with bioturbated gray mud 
Figure F17. Abundance and preservation of diatoms, radiolarians, and benthic and planktonic foraminifers, Site U1417. NPD = Neogene North Pacific Diatom zone of Yanagisawa and Akiba (1998). CM = California margin. Abundance: $\mathrm{D}=$ dominant, $\mathrm{A}=$ abundant, $\mathrm{C}=$ common, $\mathrm{F}=$ few, $\mathrm{R}=$ rare, $\mathrm{B}=$ barren. Preservation: $\mathrm{VG}$ = very good, $\mathrm{G}=$ good, $\mathrm{M}=$ moderate, $\mathrm{P}=$ poor.

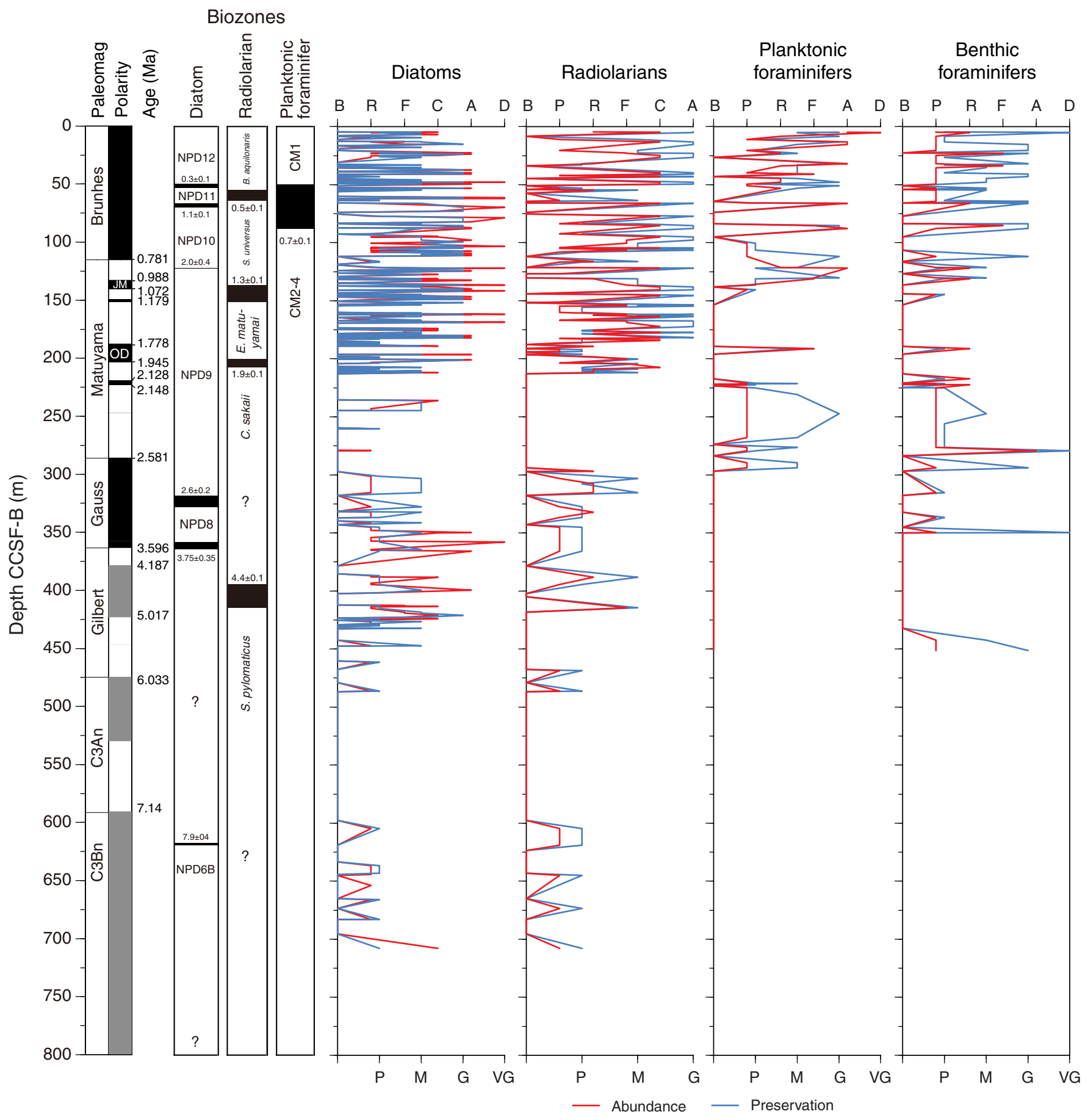


Figure F18. Micropaleontological age datums and rank abundances of taxa indicative of paleoclimatic conditions, shown as a composite from Holes U1417A-U1417E. Relative abundance of foraminifers is shown. NPD = Neogene North Pacific Diatom zone of Yanagisawa and Akiba (1998), $\mathrm{CM}=$ California margin. Abundance: $\mathrm{A}=$ abundant, $\mathrm{C}=$ common, $\mathrm{F}=$ few, $\mathrm{R}=$ rare, $\mathrm{P}=$ present, $\mathrm{X}=$ present.

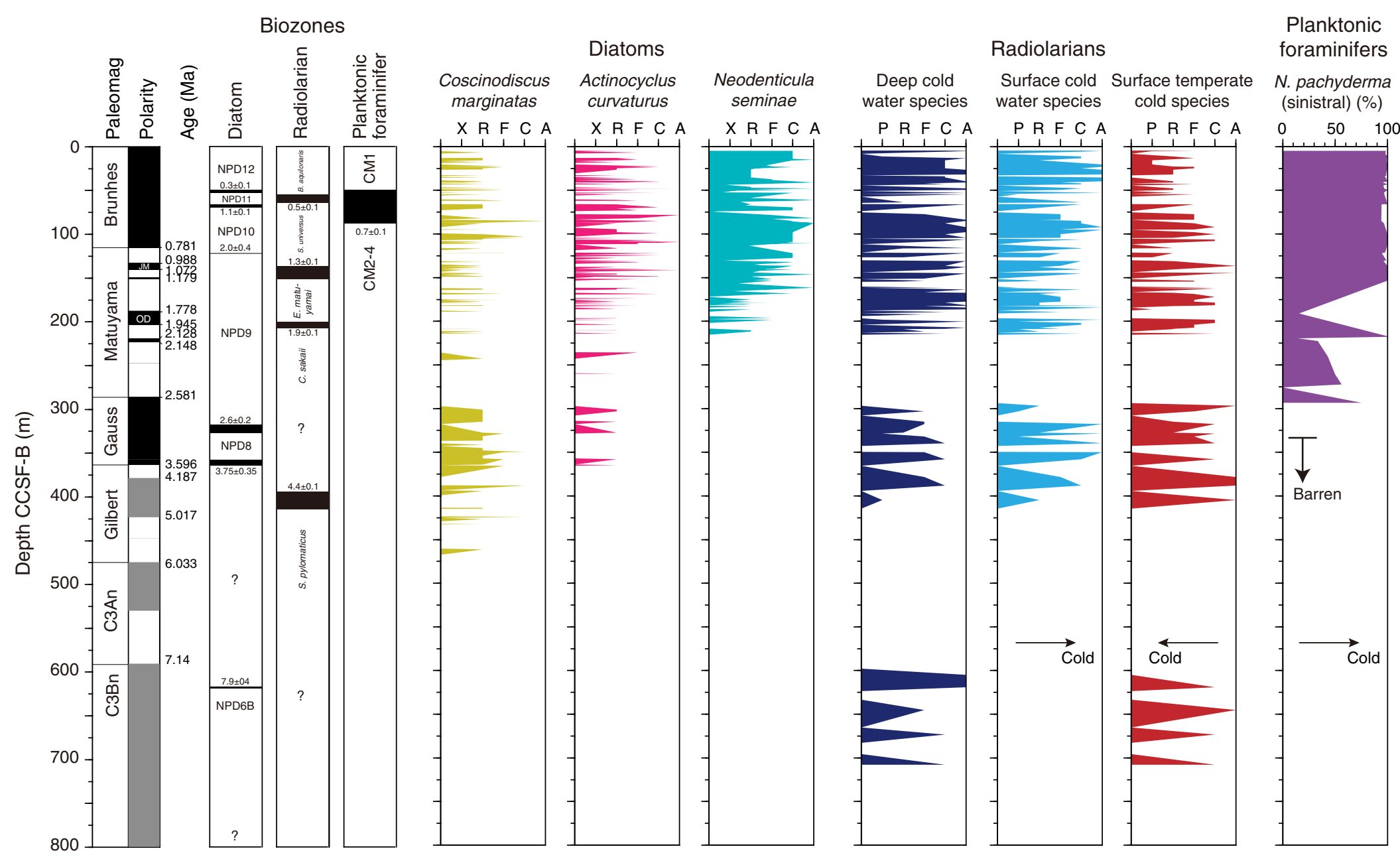


Figure F19. Micropaleontological age datums, group abundances (black plots), and rank abundances (color plots) of important paleoenvironmental indicators, shown as a composite of Holes U1417A-U1417E. Diatoms are plotted using the highest of individual species abundances within each species suite, estimated from the number of valves per field of view. Rank abundance of cold-water radiolarians is estimated from the proportional abundances of cold-water species in the total radiolarian assemblage. Rank abundance of Neogloboquadrina pachyderma (dextral), a warmwater indicator, is estimated from its proportional abundance in the total foraminiferal assemblage. NPD $=$ Neogene North Pacific Diatom zone of Yanagisawa and Akiba (1998), $\mathrm{CM}=$ California margin. Abundance: $\mathrm{D}=$ dominant, $\mathrm{A}=$ abundant $, \mathrm{C}=\mathrm{common}, \mathrm{F}=$ few, $\mathrm{R}=\mathrm{rare}, \mathrm{P}=$ present, $\mathrm{X}=$ present, $\mathrm{B}=$ barren.

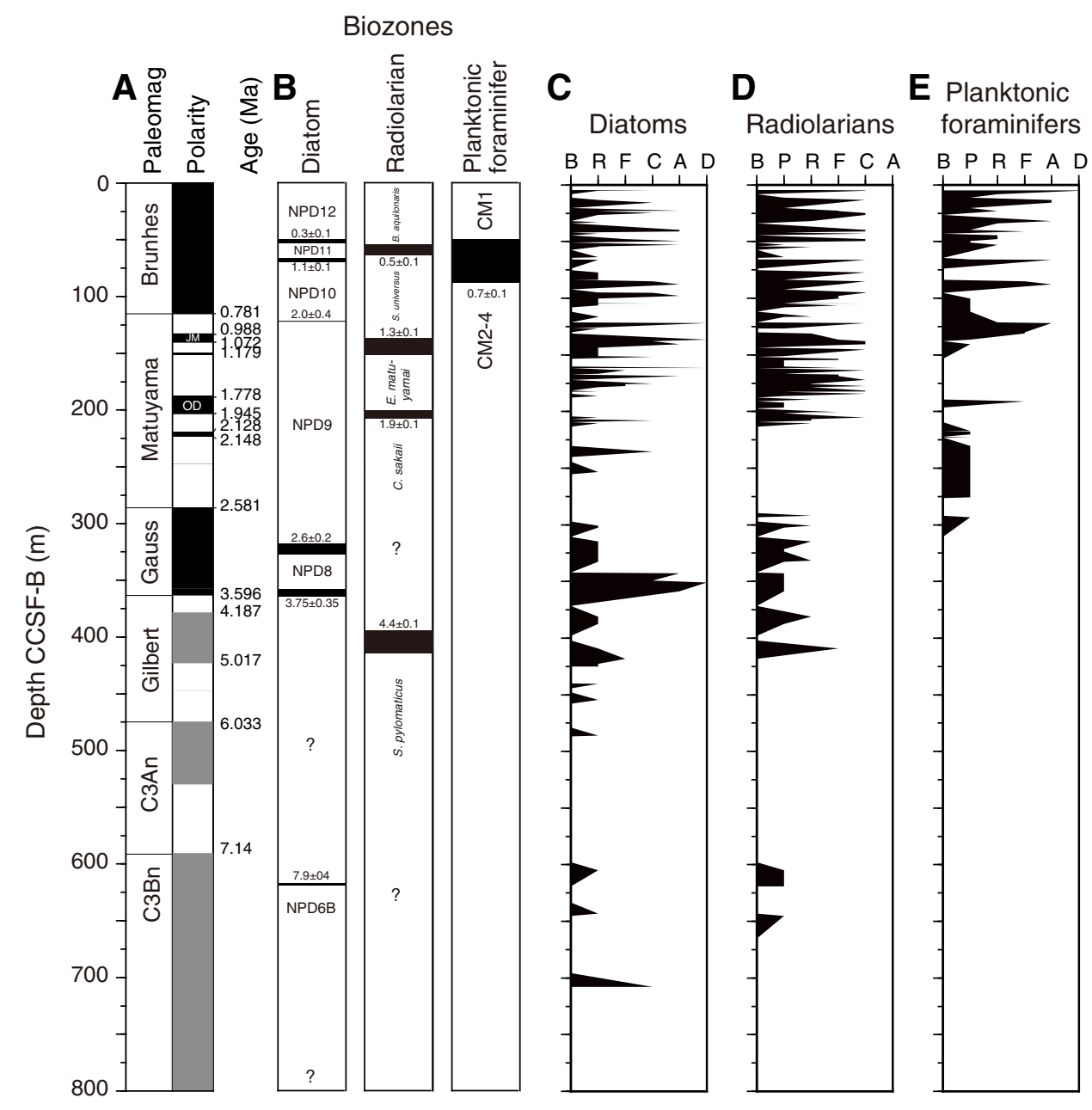
F Benthic foraminifers
Diatoms
G Cold-water Cold-water
species $\mathbf{H}_{\text {Littoral and }}$
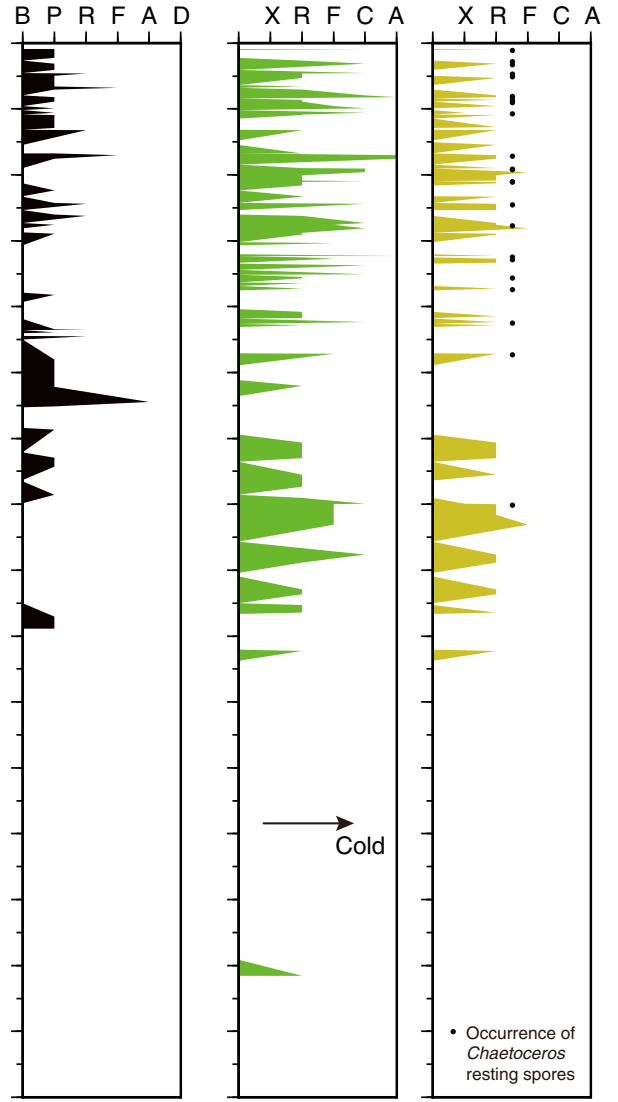

Radiolarian

Planktonic

foraminifers N. pachyderma species (dextral)

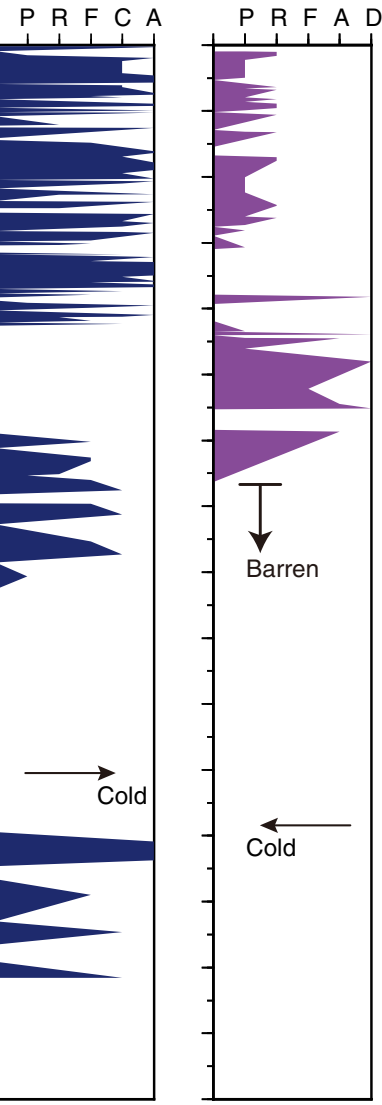


Figure F20. Micropaleontological age datums and rank abundance of important biostratigraphic diatom and radiolarian indicators, shown as a composite from Holes U1417A-U1417E. Composite diatom biostratigraphy shows relative abundance (\%) of eight diatom species (Neodenticula seminae, Proboscia curvirostris, Proboscia barboi, Actynocyclus oculatus, Neodenticula koizumii, Neodenticula kamtschatica, Shionodiscus oestrupii, and Stephanopyxis horridus). Composite radiolarian biostratigraphy shows relative abundance (\%) of ten radiolarian species (Lynchnocanoma sakaii, Axoprunum acquilonium, Stylaconturium universus, Eucyrtidium matuyamaii, Sphaeropyle robusta, Cycladophora sakaii, Cycladophora davisiana, Thecosphaera akitaensis, Phormocyrtis fistula, and Thecosphaera pseudojaponica). NPD = Neogene North Pacific Diatom zone of Yanagisawa and Akiba (1998). FO = first occurrence, $\mathrm{LO}=$ last occurrence.

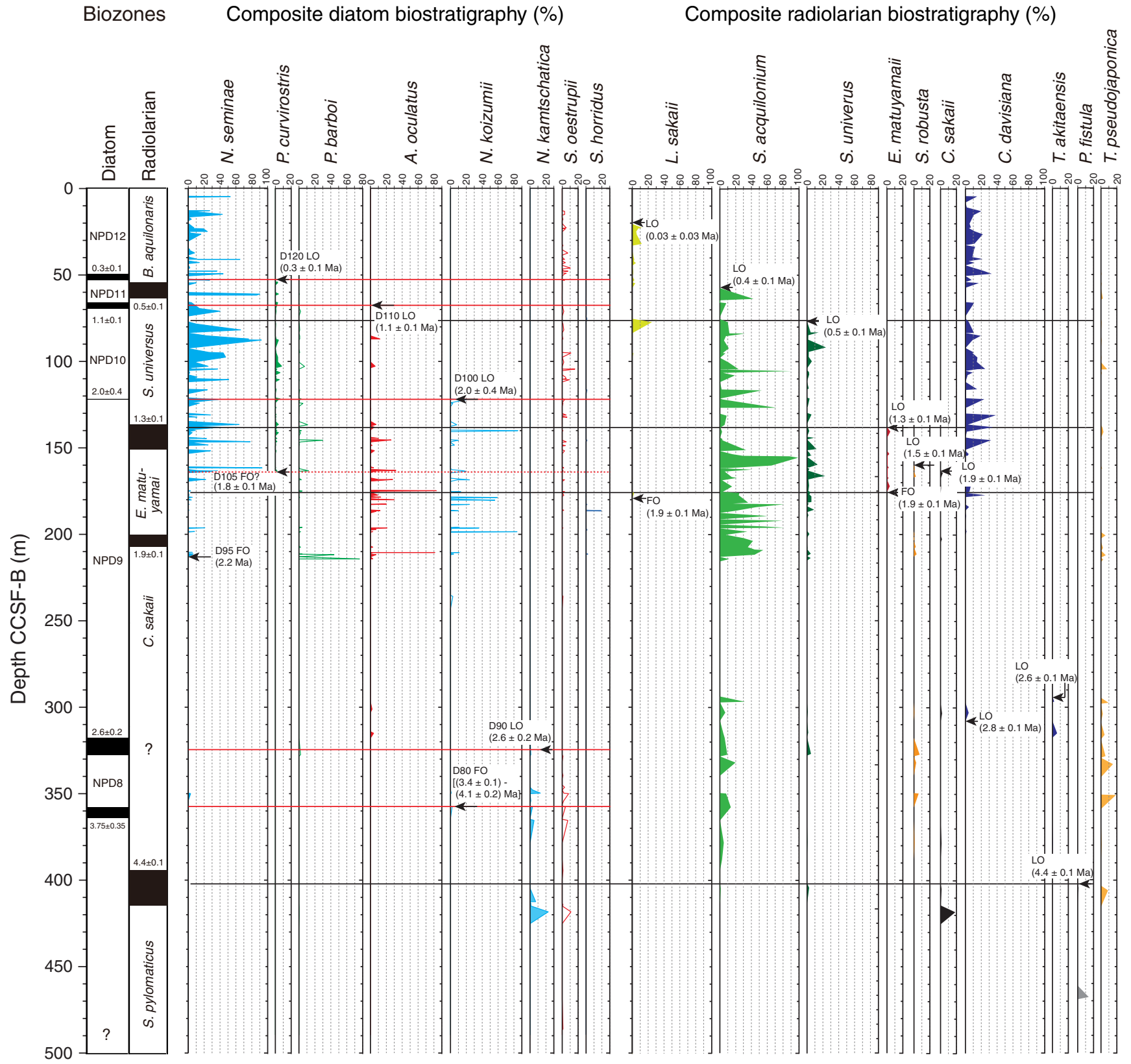


Figure F21. Magnetic susceptibility data for the interval of the continuous splice in Holes U1417A-U1417D and the splice record. Gray boxes = intervals used to construct the splice with core numbers noted, dashed vertical lines $=$ intervals where tie points should be treated with caution (see text for details). A. 0-50 m CCSF-A. (Continued on next three pages.)

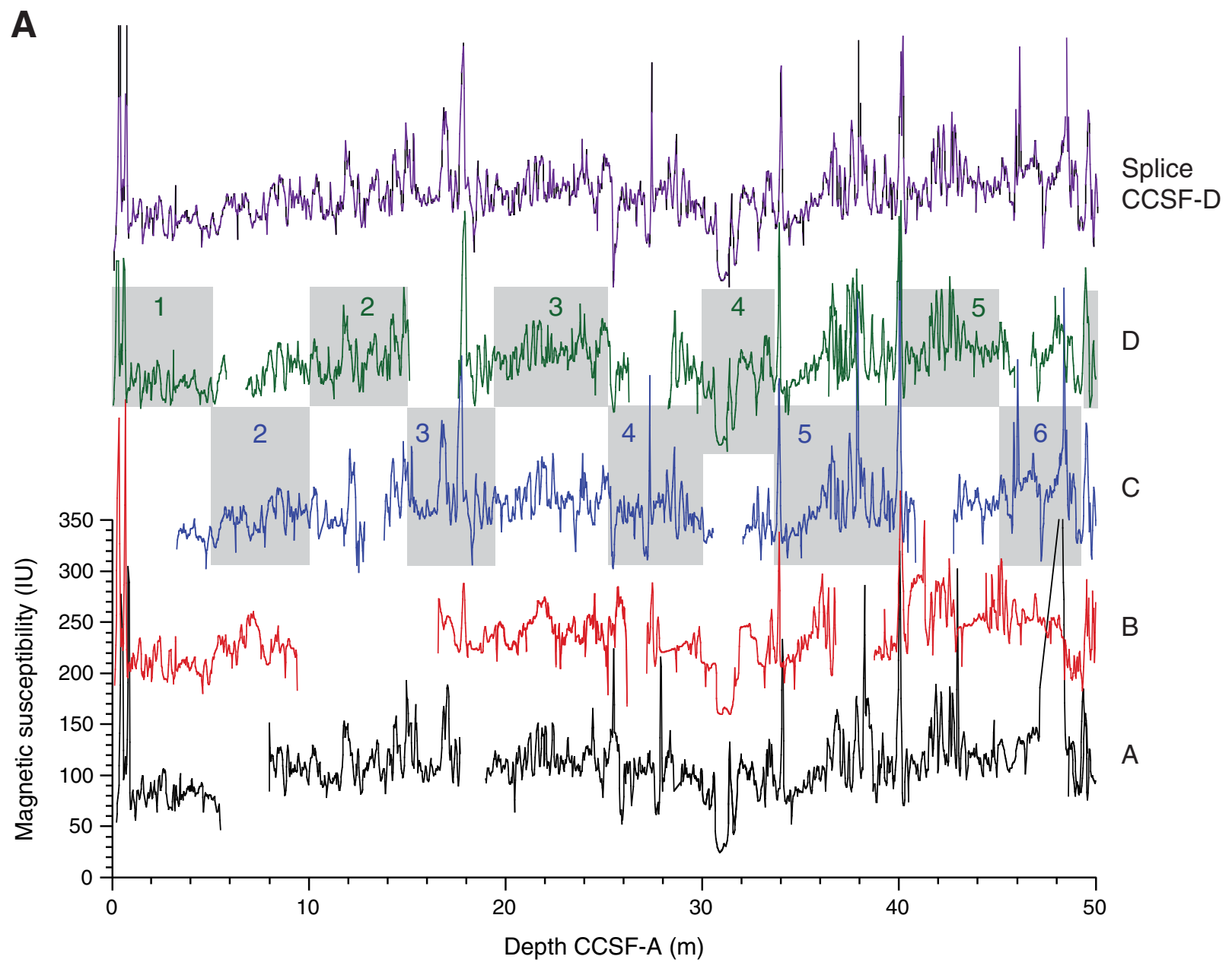


Figure F21 (continued). B. 50-100 m CCSF-A. (Continued on next page.)

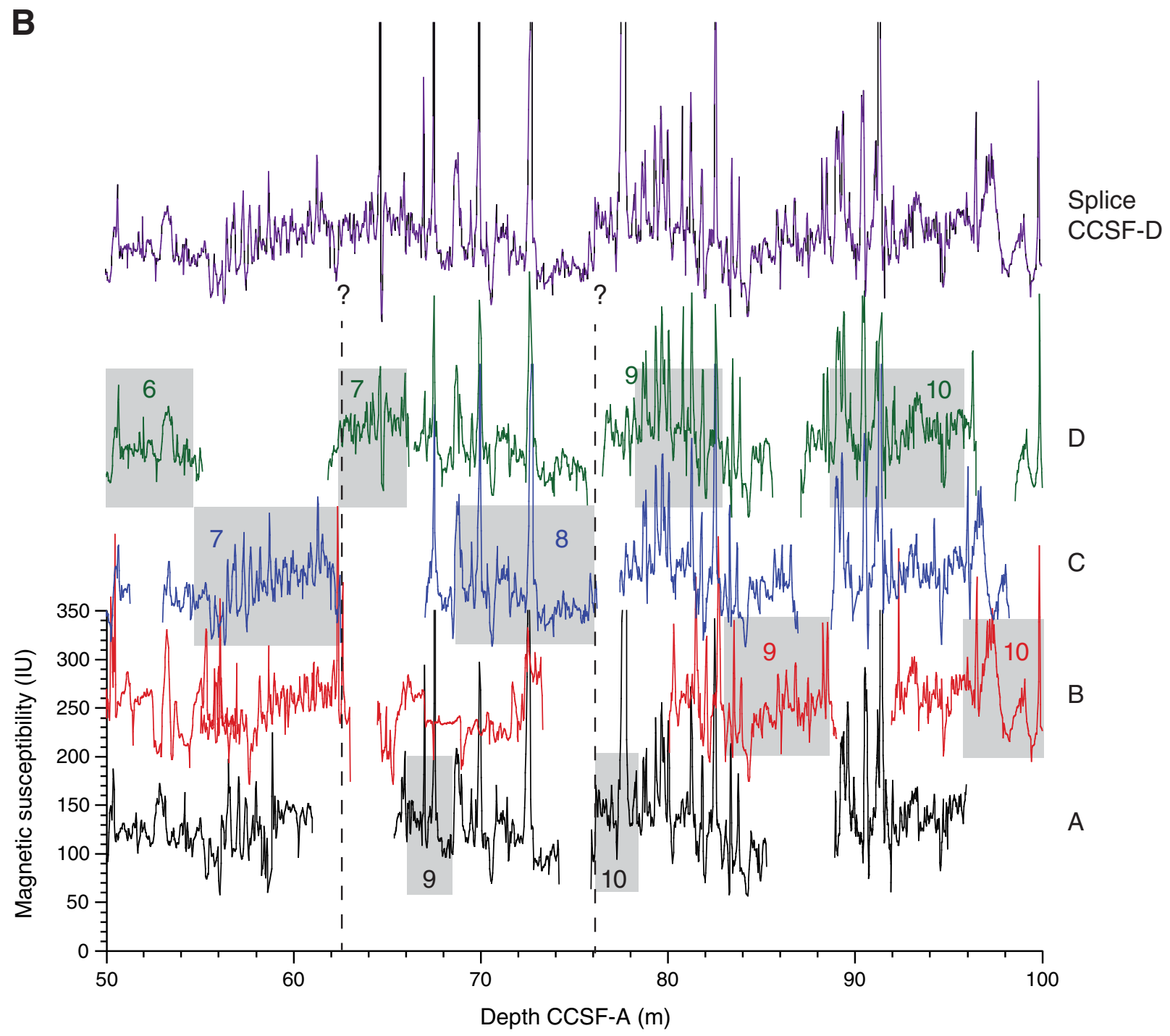


Figure F21 (continued). C. 100-150 m CCSF-A. (Continued on next page.)

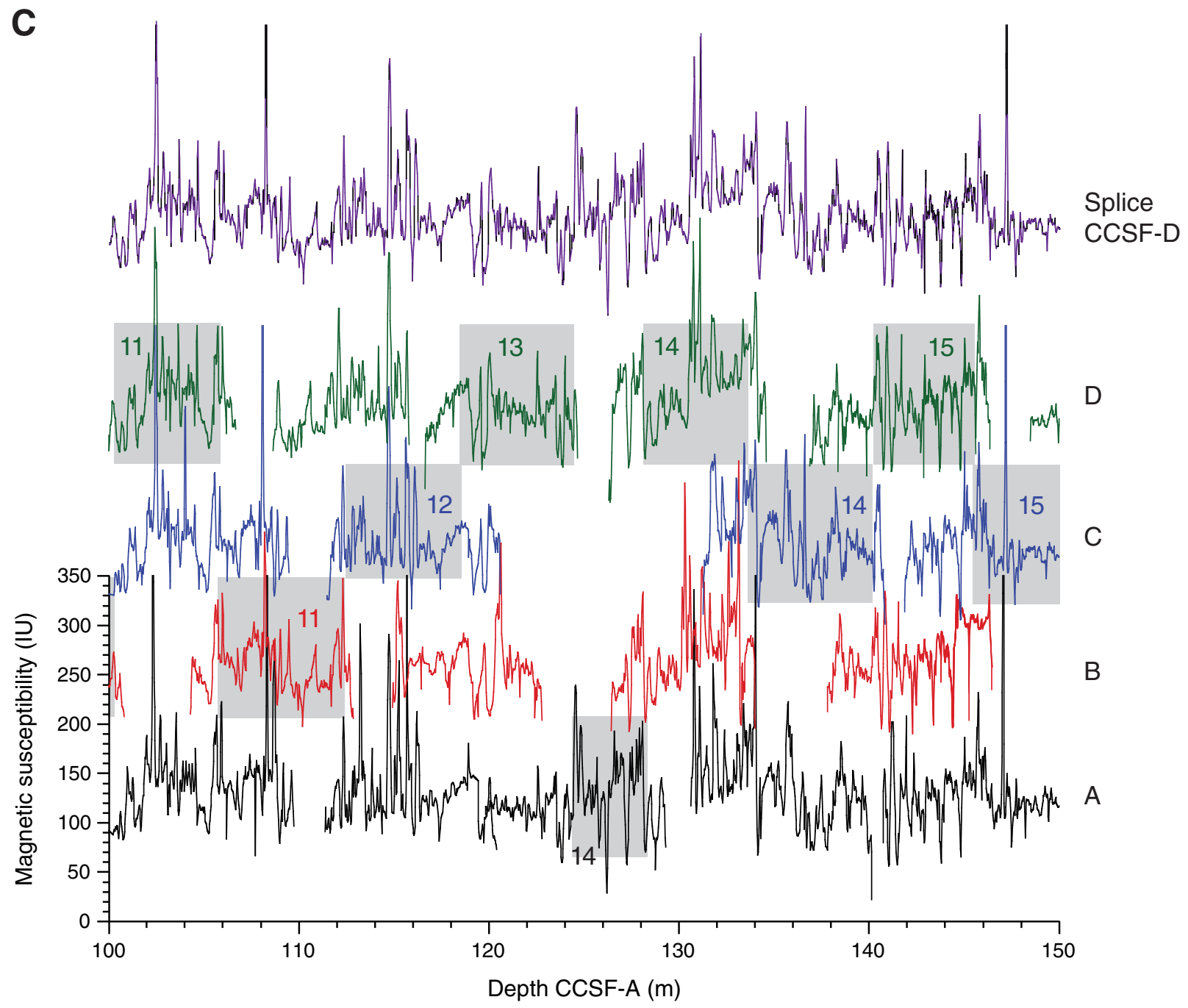


Figure F21 (continued). D. 150-225 m CCSF-A.

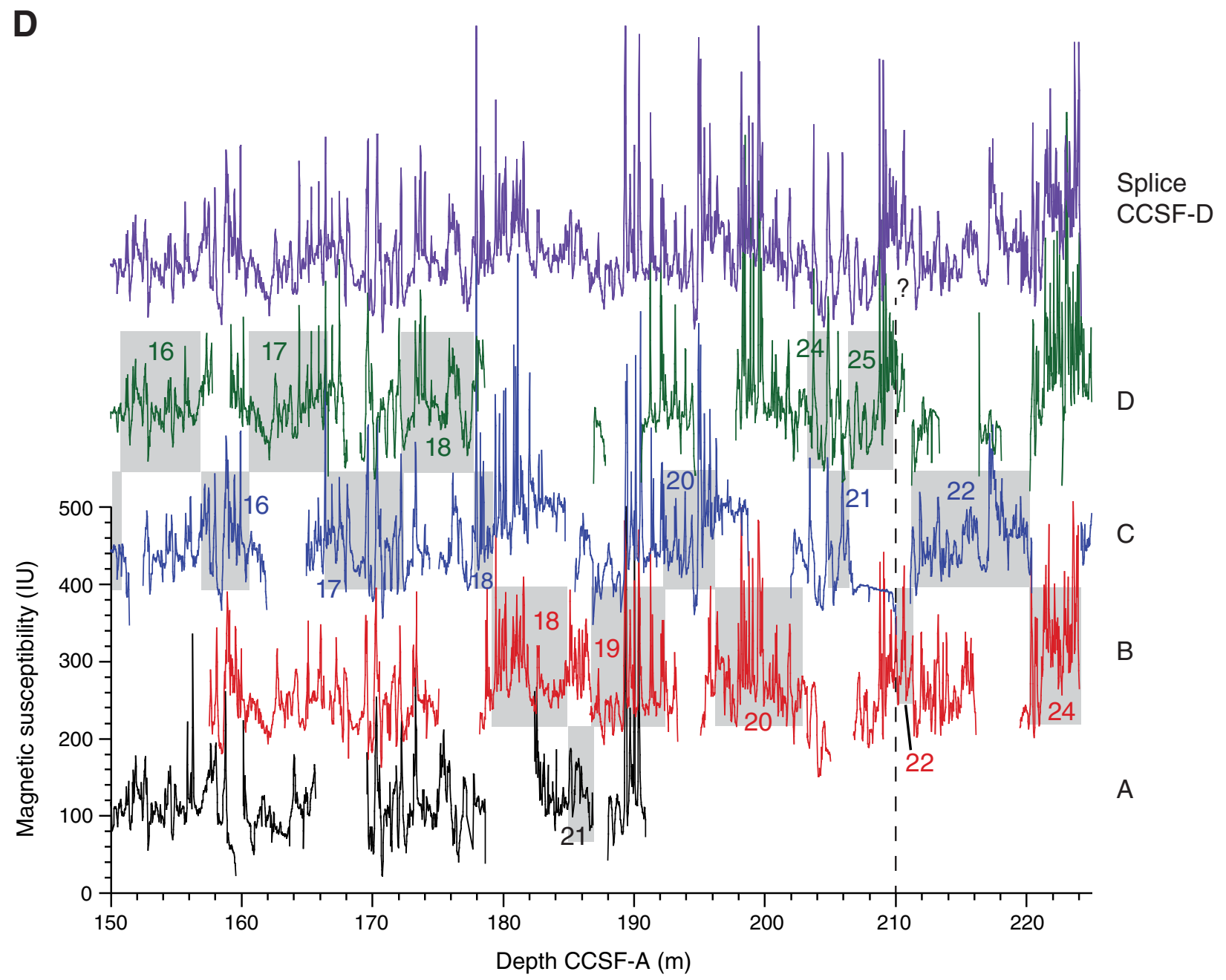


Figure F22. GRA bulk density data for the interval of the continuous splice in Holes U1417A-U1417D and the splice record. Gray boxes = intervals used to construct the splice with core numbers noted, dashed vertical lines $=$ intervals where tie points should be treated with caution (see text for details). A. 0-50 m CCSF-A. (Continued on next three pages.)

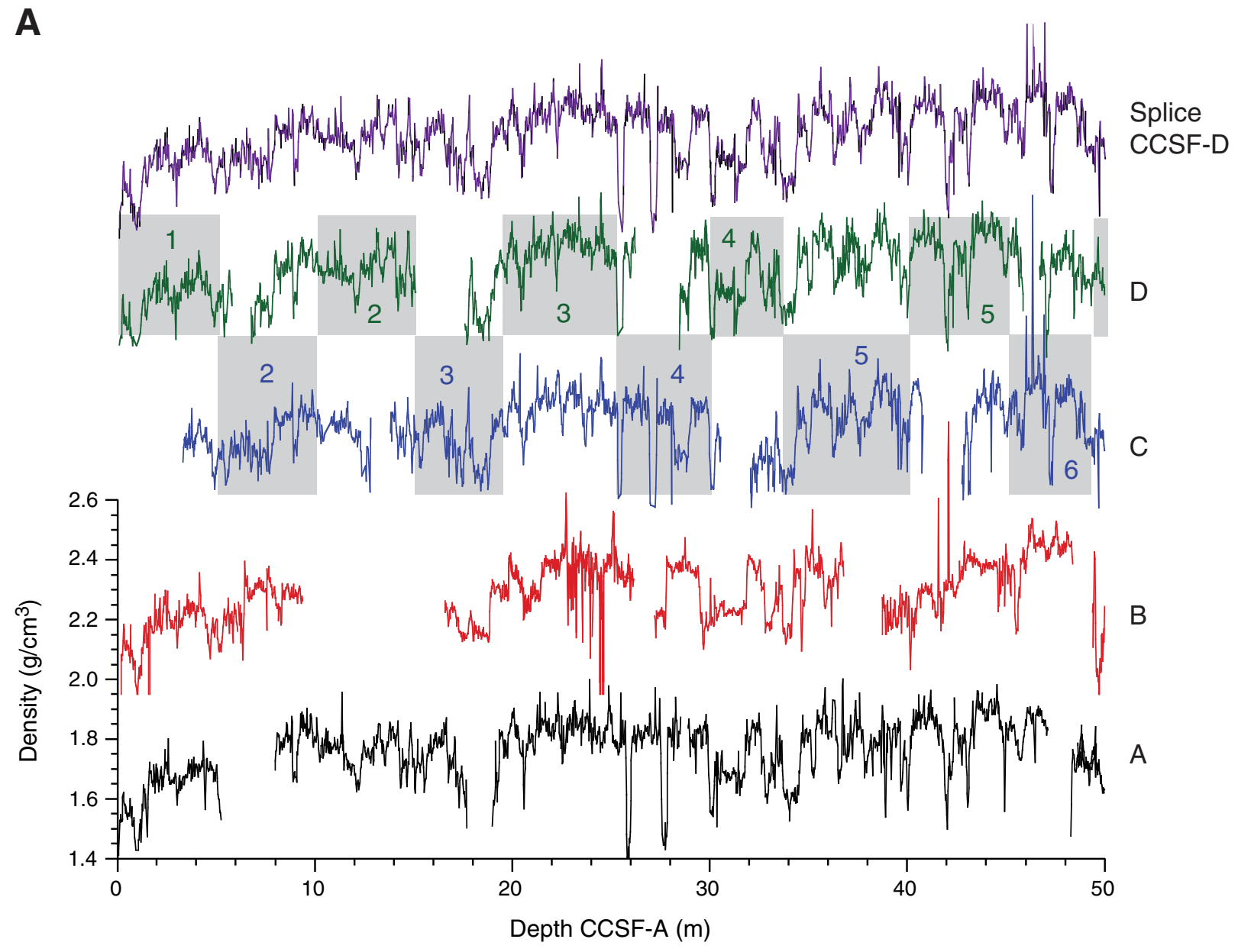


Figure F22 (continued). B. 50-100 m CCSF-A. (Continued on next page.)

B

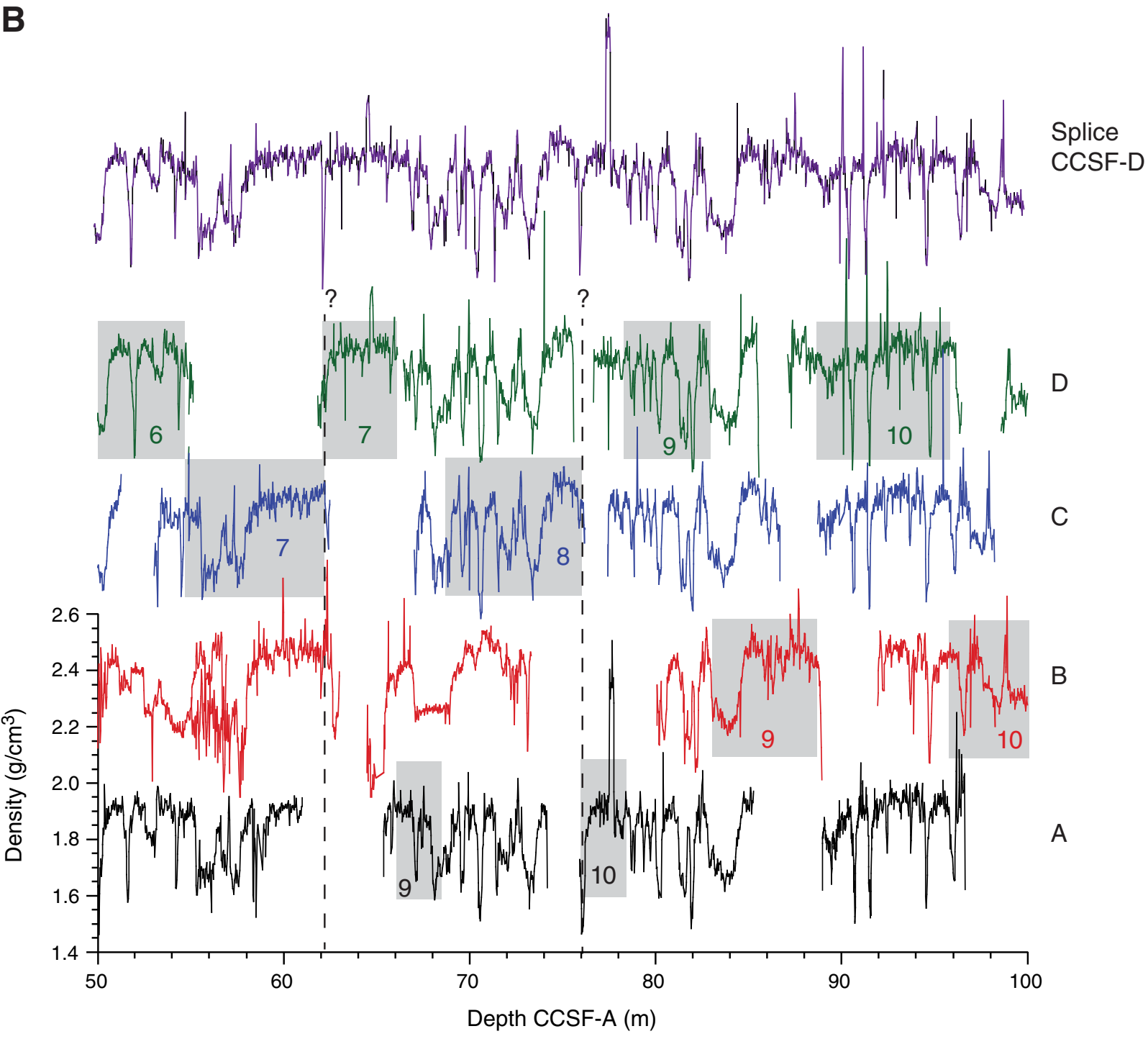


Figure F22 (continued). C. 100-150 m CCSF-A. (Continued on next page.)

C

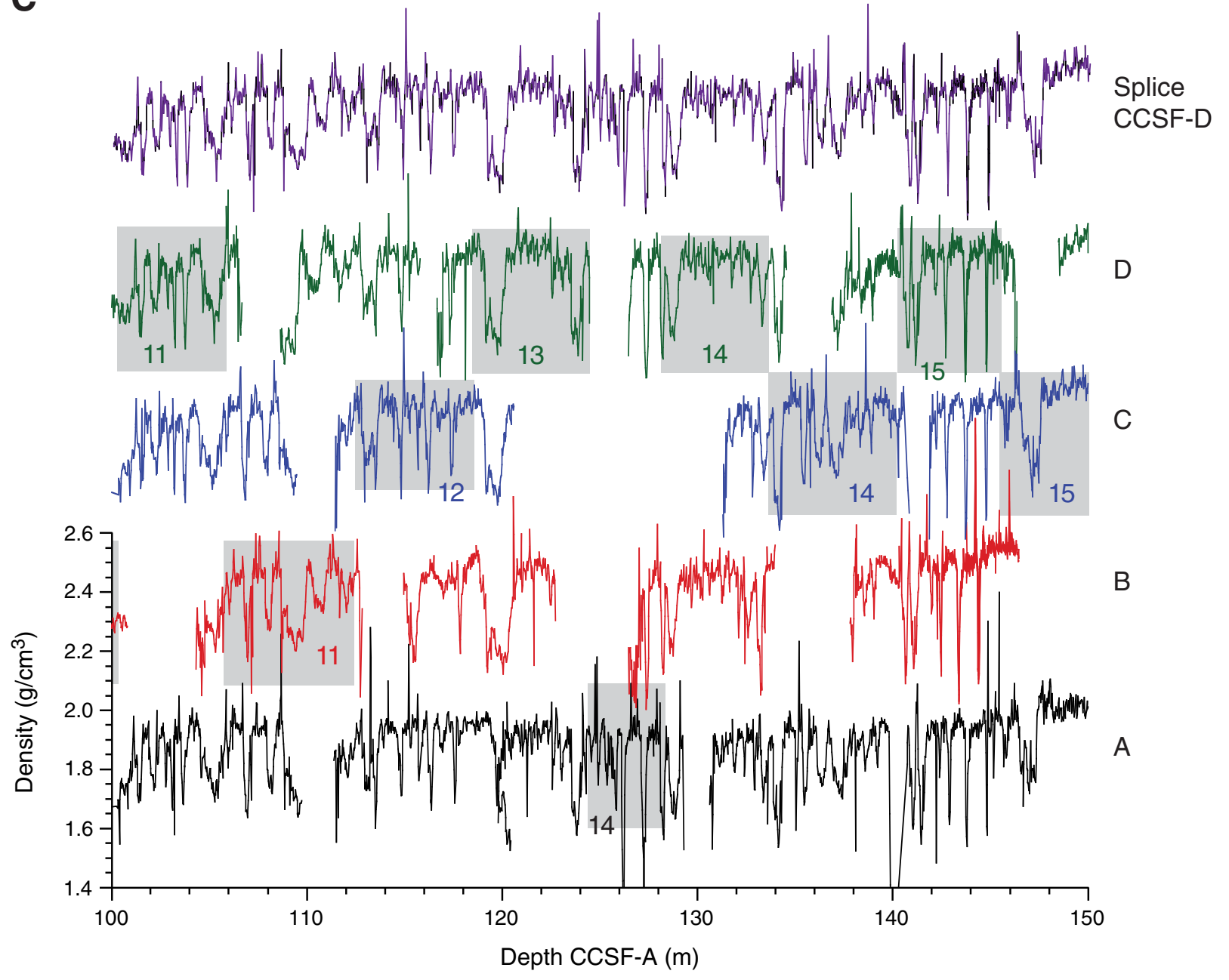


Figure F22 (continued). D. 150-225 m CCSF-A.

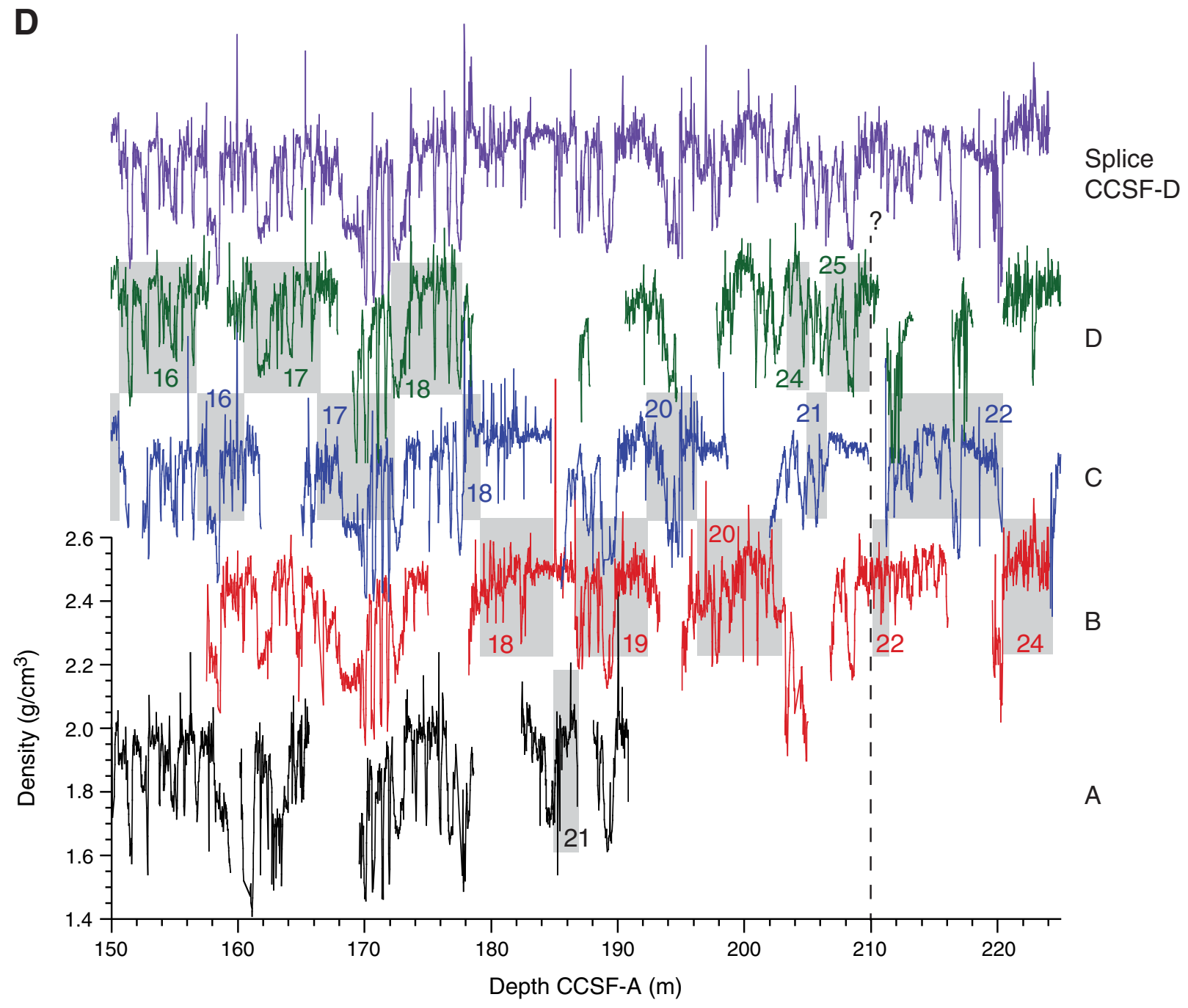


Figure F23. Affine values, Holes U1417A-U1417E. Equations denote the relationship between the affine values and core top depth for each of the two segments of the line of best fit (black line).

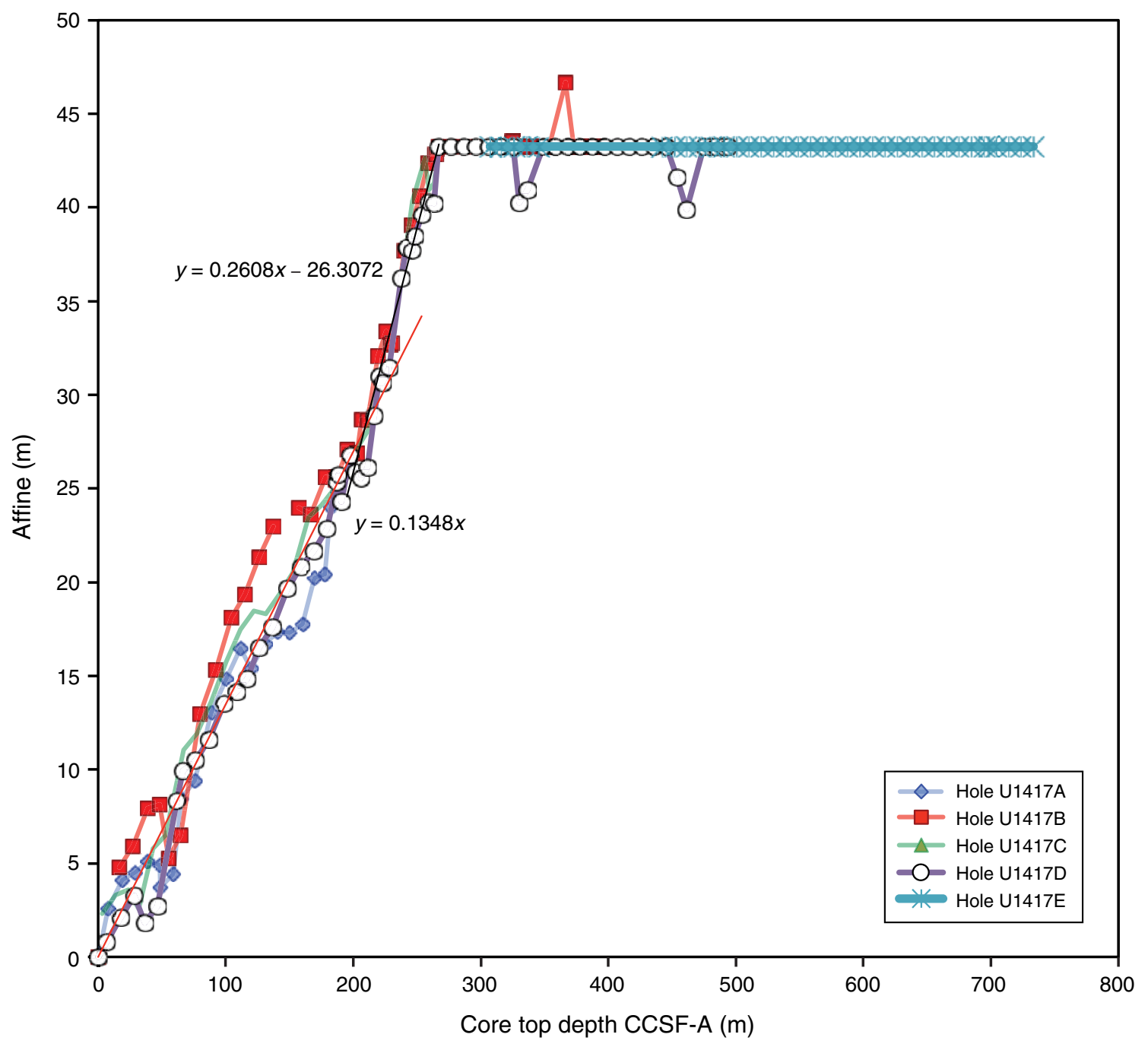


Figure F24. Shipboard age model, Site U1417. Diamonds = biostratigraphic ages, squares $=$ paleomagnetic ages, triangles $=$ extrapolation from the base of the borehole to underlying oceanic crust. Bars on the datums are depth and age uncertainties, here assumed to represent $\pm 2 \sigma$ uncertainties. Red and blue lines are visually estimated minimum and maximum initial age models. A. 0-40 Ma. B. 0-12 Ma. C. 0-5 Ma.

A

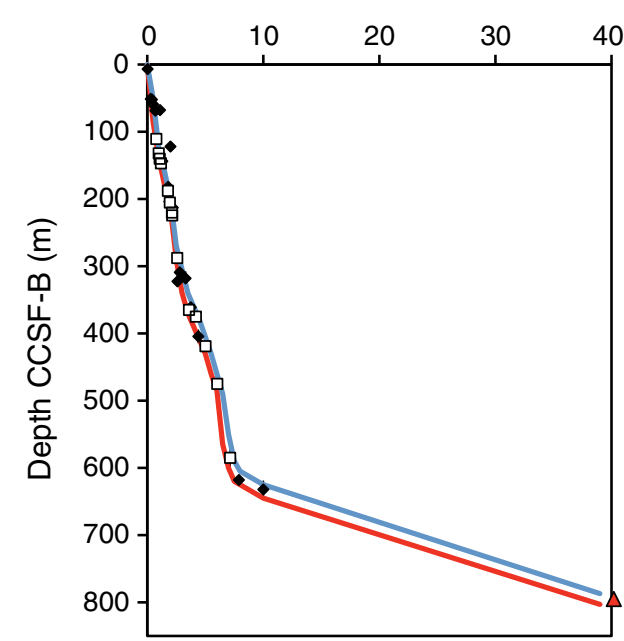

B

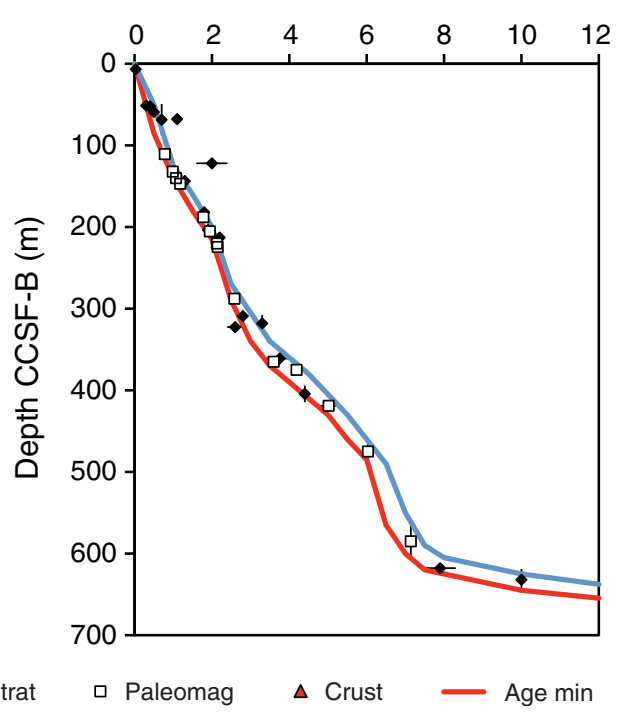

C
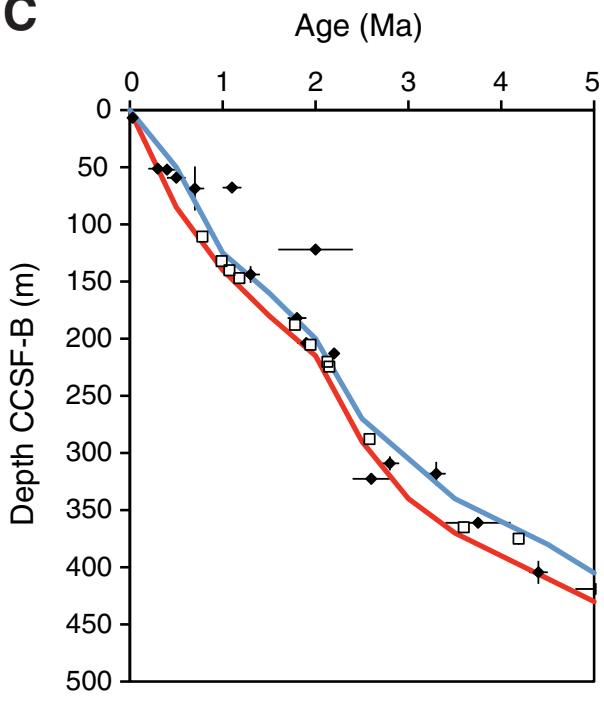
Figure F25. Sedimentation rates estimated based on CCSF-B depth model and shipboard age models, Site U1417. Average sedimentation rates (solid line) are calculated over $0.5 \mathrm{~m}$.y. intervals from 0 to $10 \mathrm{Ma}$ and over a single interval of 10-39 Ma. Uncertainties $( \pm 1 \sigma)$ in sedimentation rate, estimated from 500 iterations of a Monte-Carlo sedimentation model, are bracketed by dashed lines. A. 0-40 Ma. B. Sedimentation rates as a function of m CCSF-B depth. C. 0-12 Ma. D. 0-5 Ma, with sedimentation rates (solid black lines) and uncertainties (dashed black lines) superimposed on the global $\delta^{18} \mathrm{O}$ stack in pink (data from Lisiecki and Raymo, 2005) with long-term $\delta^{18} \mathrm{O}$ variations (red line, $\delta^{18} \mathrm{O}$ data smoothed with a Gaussian filter of $500 \mathrm{ka} \pm 3 \sigma$ width).
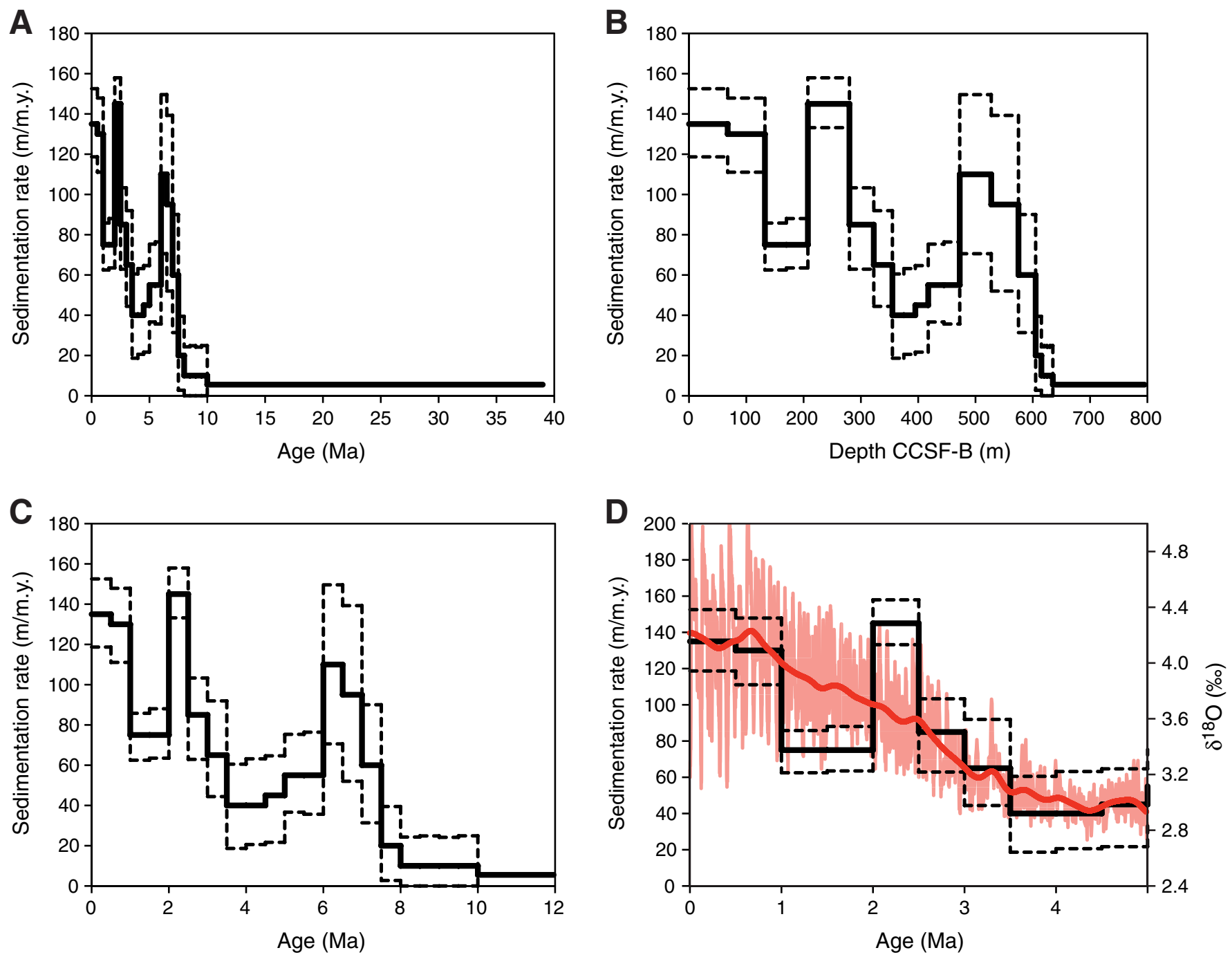
Figure F26. Dissolved chemical concentrations and headspace gas, Site U1417. A. Alkalinity. B. pH. C. Sulfate. D. Ammonium. E. Bromide. F. Methane. G. Silica. H. Salinity. I. Chloride. J. Sodium. Full details of Lithology column are shown in Figure F16 (see "Lithostratigraphy").

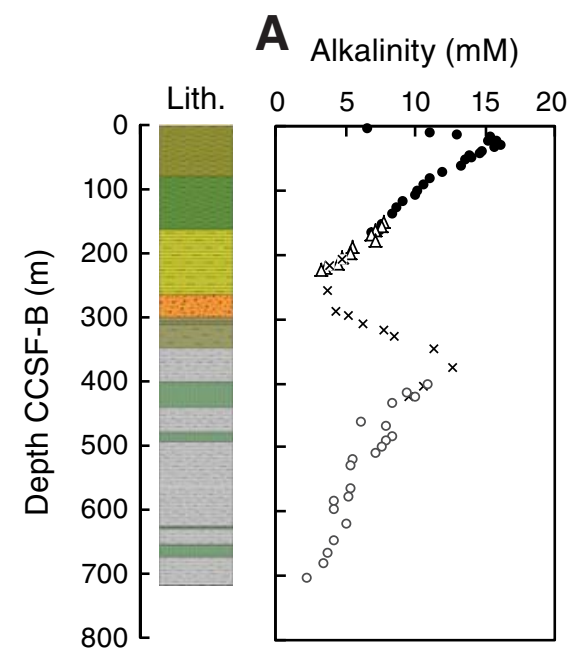

B

C Sulfate $(\mathrm{mM})$

$\mathbf{D}_{\text {Ammonium (mM) }}$

E Bromide (mM)
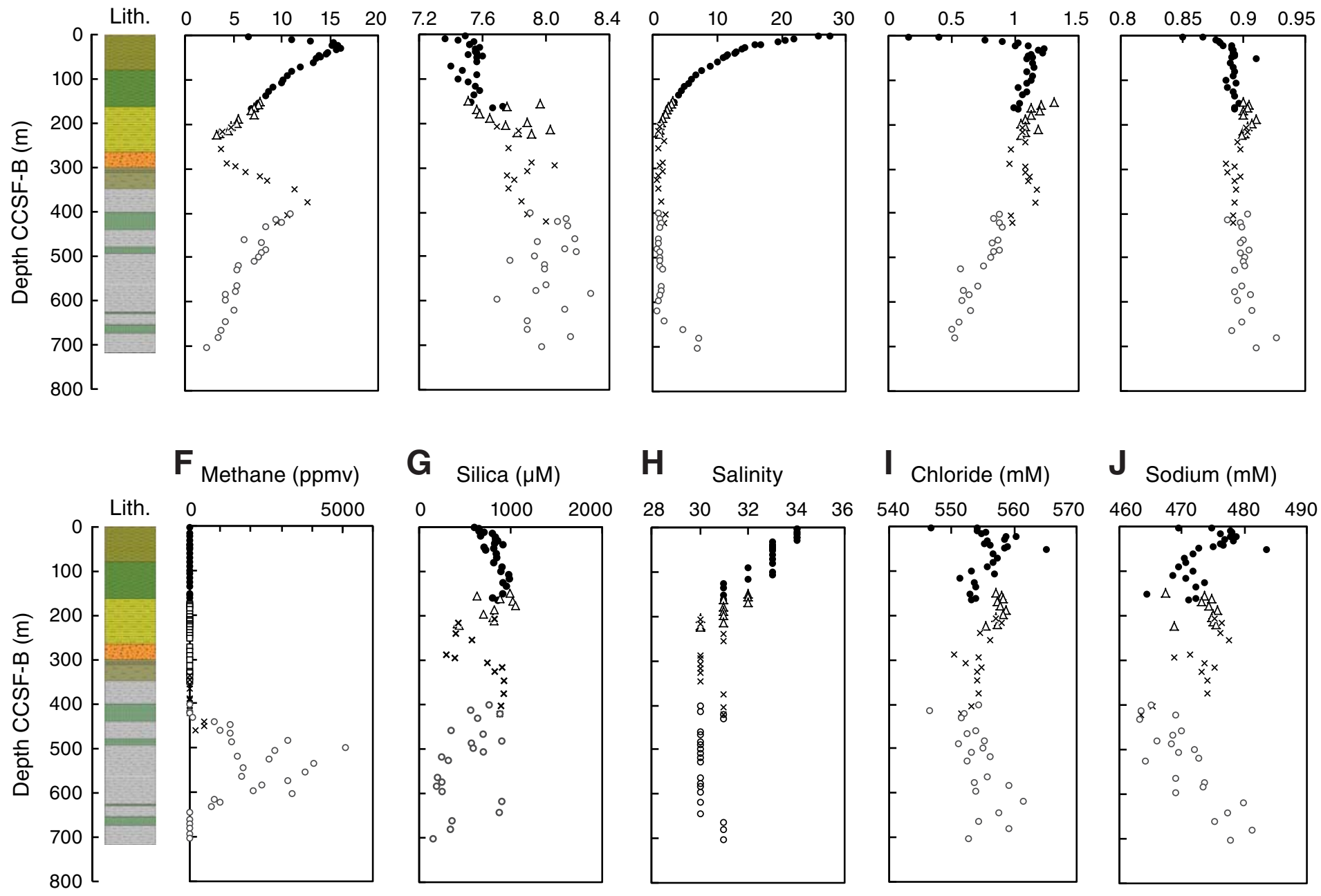

H Salinity

I Chloride (mM)

J Sodium (mM)
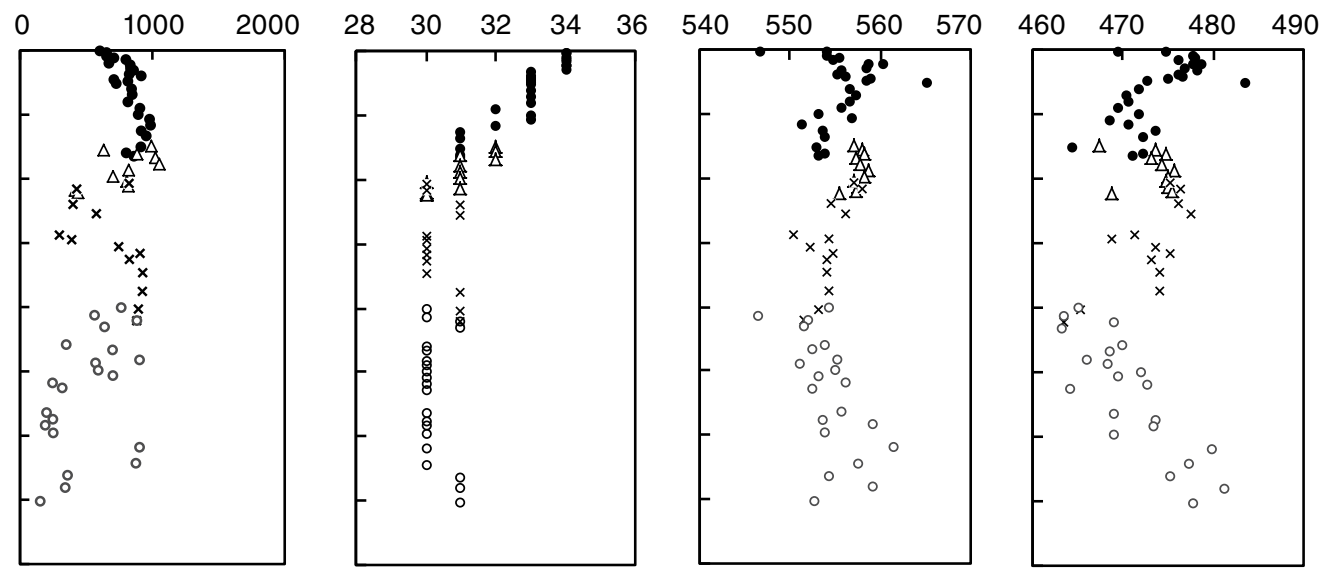

- Hole U1417A

$\triangle$ Hole U1417C

$\times$ Hole U1417D

- Hole U1417E 
Figure F27. Dissolved chemical concentrations, Site U1417. A. Calcium. B. Potassium. C. Magnesium. D. Lithium. E. Boron. F. Barium. G. Strontium. H. Iron. I. Manganese. J. Phosphate. Full details of Lithology column are shown in Figure F16 (see "Lithostratigraphy").
A Calcium (mM)
B Potassium (mM)
C Magnesium (mM)
D Lithium $(\mu \mathrm{M})$
E Boron $(\mu \mathrm{M})$
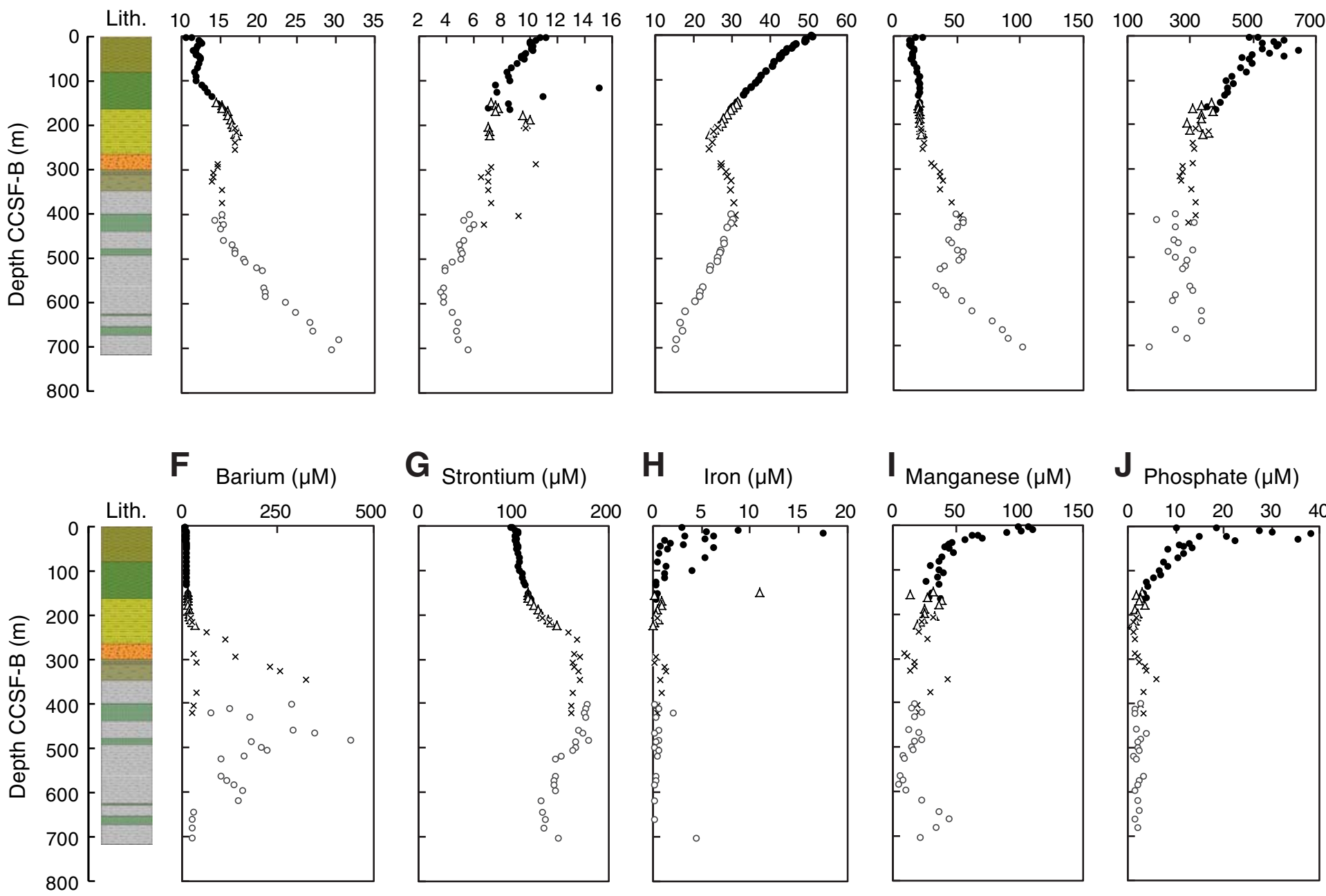

G Strontium $(\mu \mathrm{M})$

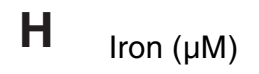

I Manganese $(\mu \mathrm{M})$

J Phosphate $(\mu \mathrm{M})$
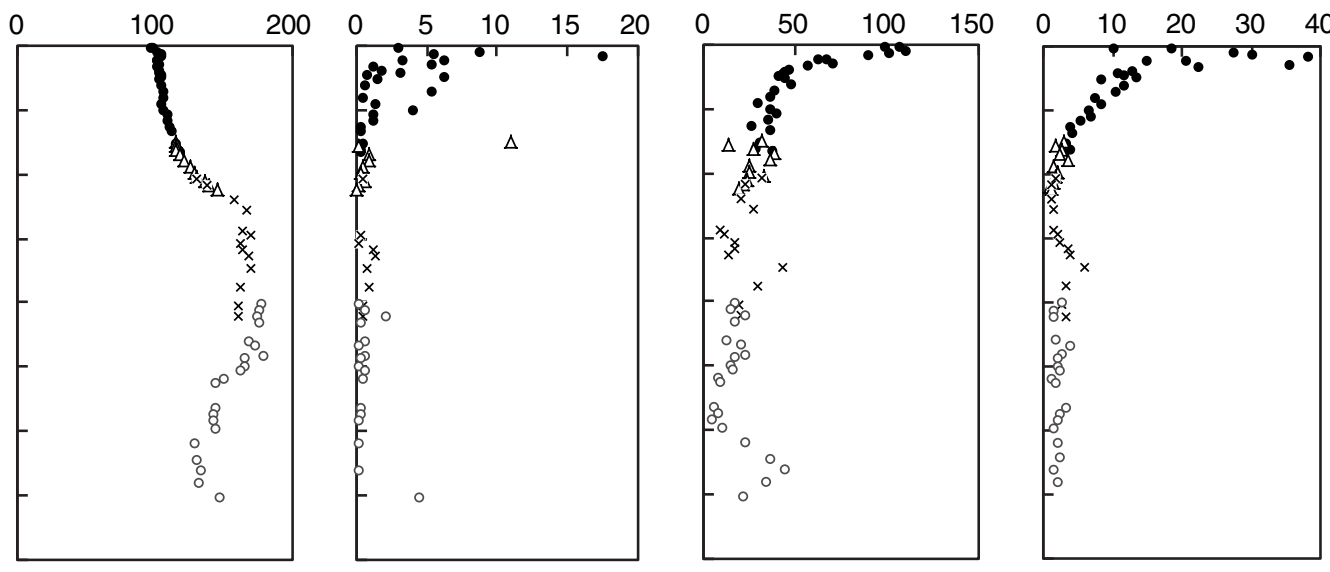

- Hole U1417A

$\triangle$ Hole U1417C

$\times$ Hole U1417D

- Hole U1417E 
Figure F28. Solid-phase chemical parameters, Site U1417. A. Full range of total organic carbon (TOC) content. B. Subset of TOC content ( $<2.5$ wt\%). C. Total nitrogen (TN). D. Full range of $\mathrm{CaCO}_{3}$ content. E. Subset of $\mathrm{CaCO}_{3}$ content $(<5 \mathrm{wt} \%)$. F. Scatter plot of TOC vs. TN. The potential contribution of inorganic $\mathrm{N}$ to the TN signal is estimated where the linear regression line intercepts the $y$-axis (e.g., Schubert and Calvert, 2001). Full details of Lithology column are shown in Figure F16 (see "Lithostratigraphy").

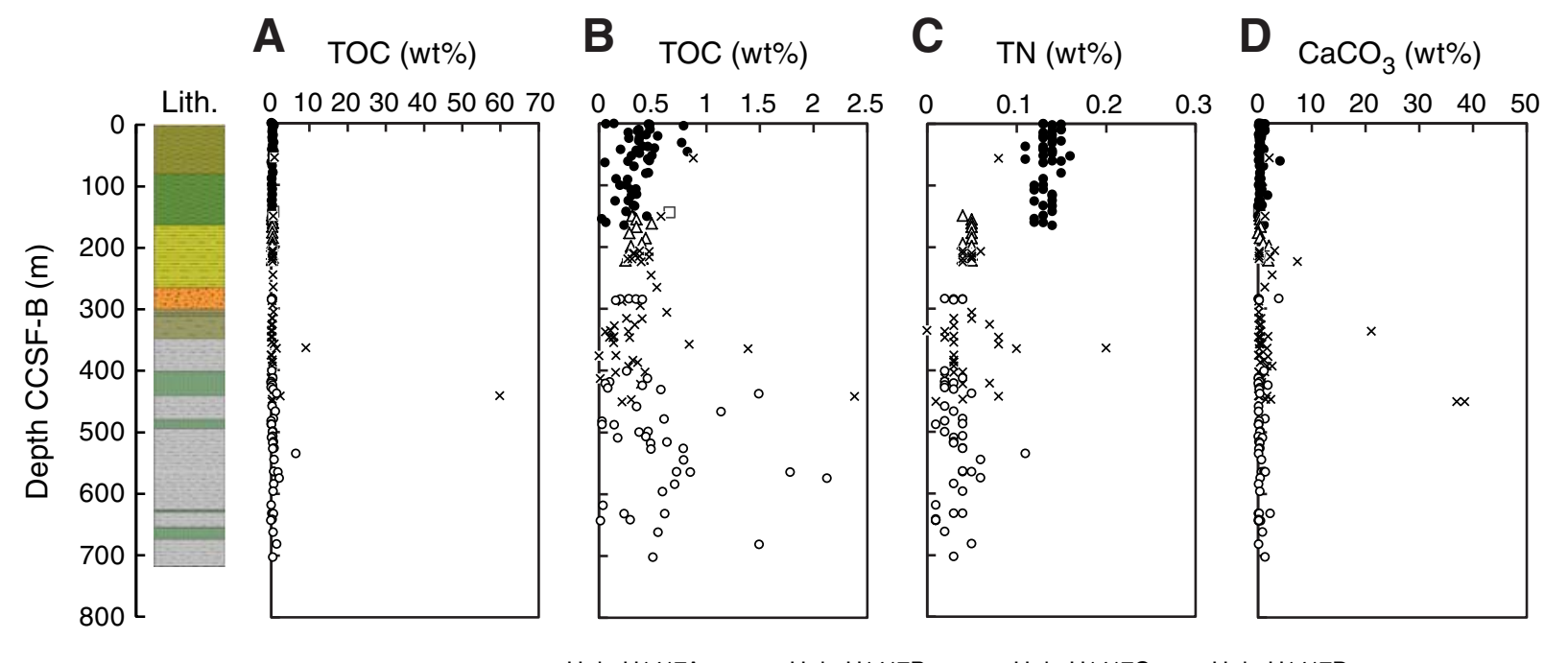

E $\mathrm{CaCO}_{3}(\mathrm{wt} \%)$

- Hole U1417A a Hole U1417B

$\Delta$ Hole U1417C $\times$ Hole U1417D

$\circ$ Hole U1417E

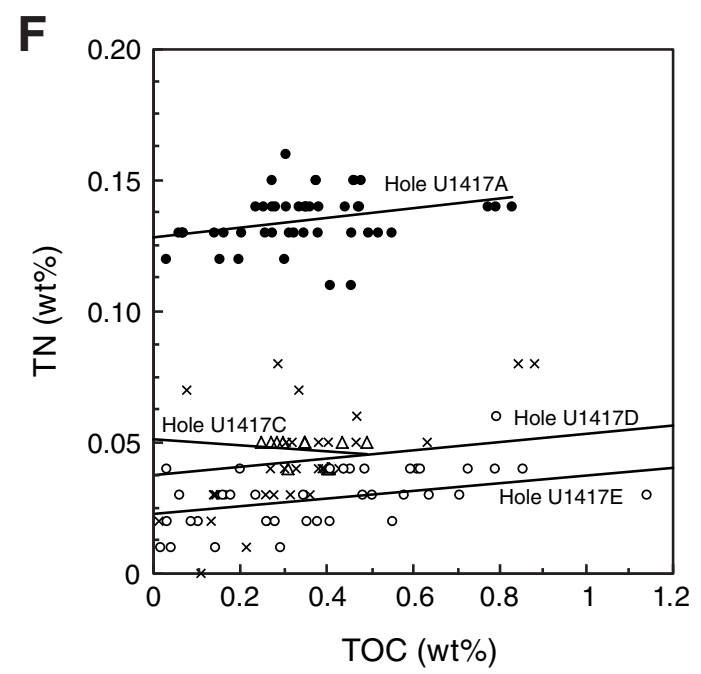


Figure F29. Dissolved chemical concentrations, solid-phase chemical parameters, and headspace gas concentrations for the upper $150 \mathrm{~m}$ CCSF-B at Site U1417. A. Alkalinity. B. Sulfate. C. Ammonium. D. Chloride. E. Sodium. F. Phosphate. G. Calcium. H. Total organic carbon (TOC). I. CaCO ${ }_{3}$ J. Methane.
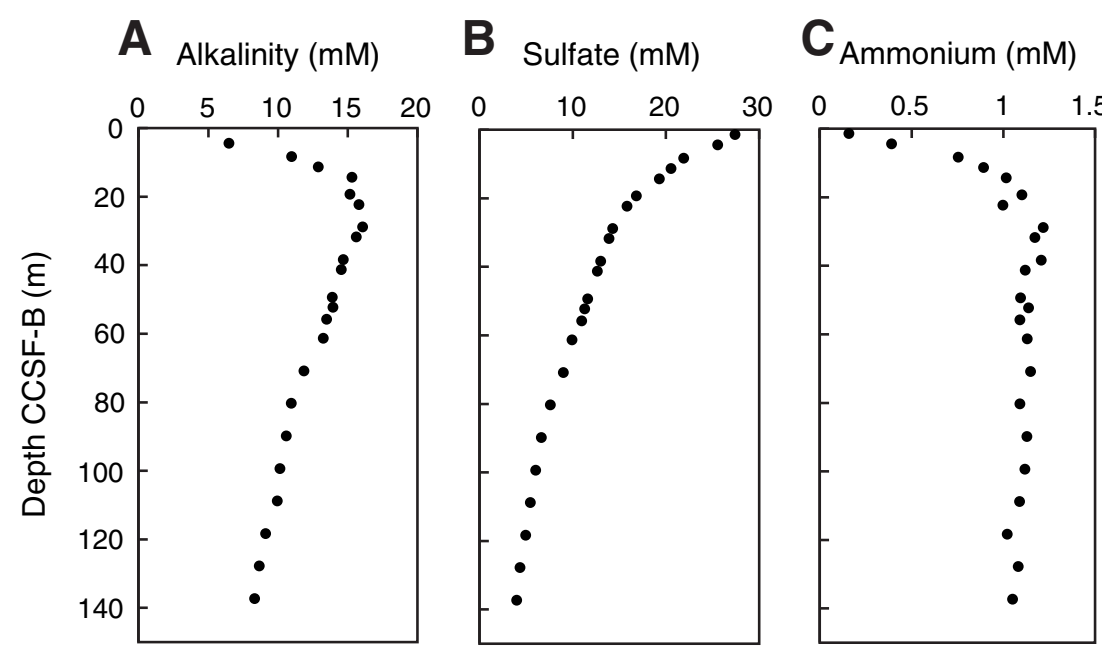

D Chloride (mM)
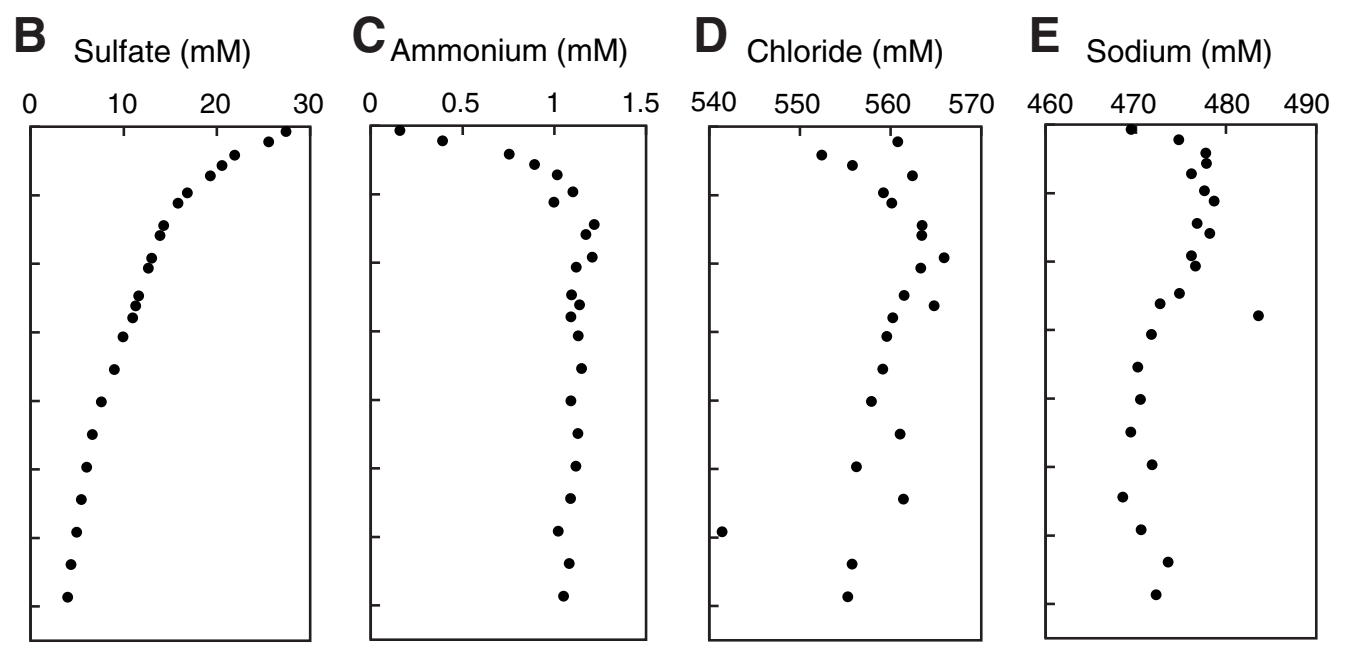

F Phosphate $(\mu \mathrm{M})$

G Calcium (mM)

H TOC (wt\%)

I $\mathrm{CaCO}_{3}(\mathrm{wt} \%)$

J Methane (ppmv)
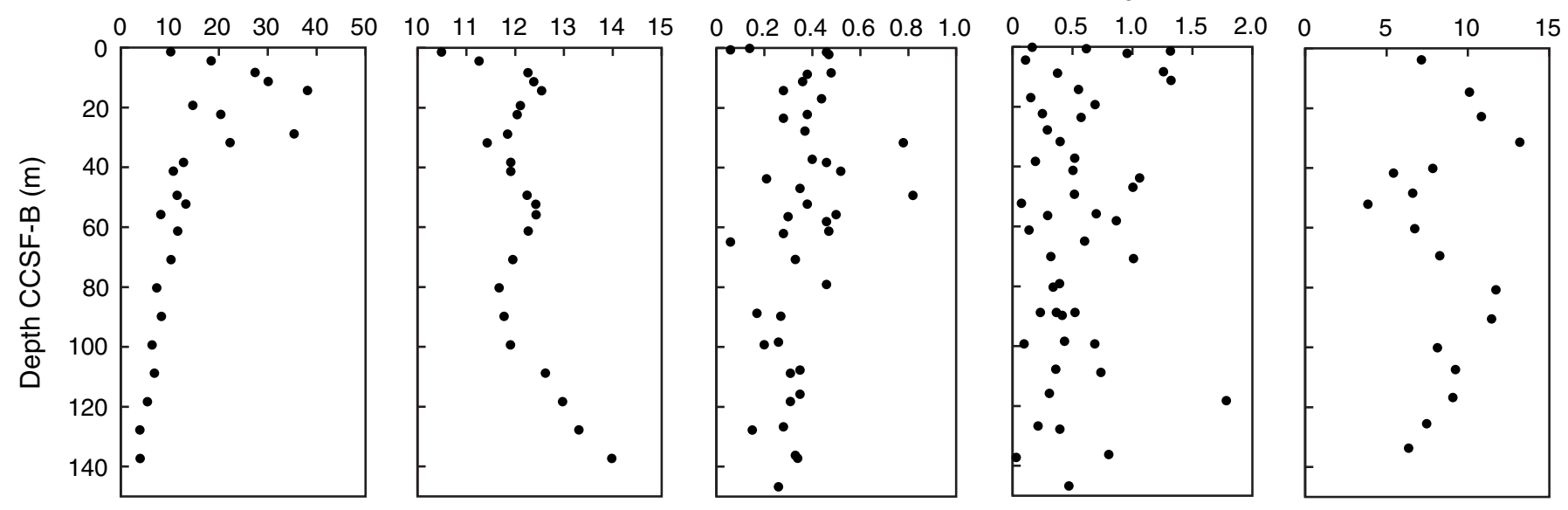
Figure F30. Downhole density and sonic logs, discrete physical properties measurements, and seismic reflection Profile MGL1109MCS01. Seismic Sequences I-III are interpreted after Reece et al. (2011) and demarcated by yellow horizons. Subsections of Sequence I (A-C) are demarcated by green horizons. Subsections of Sequence IC (IC1 and IC2) are demarcated by a blue horizon. Subsections are interpreted based on dominant seismic character. Note lack of check shot calibration below $211 \mathrm{~m}$ WMSF and up to $\sim 10 \mathrm{~m}$ depth offset when comparing CCSF-B and WMSF. MAD $=$ moisture and density, GRA $=$ gamma ray attenuation, WRMSL $=$ Whole-Round Multisensor Logger. $P$-wave data: closed symbols $=$ automatic velocity picks, open symbols $=$ manual velocity picks. TWT $=$ two-way traveltime, $\mathrm{VSP}=$ vertical seismic profile, $\mathrm{VE}=\mathrm{vertical}$ exaggeration

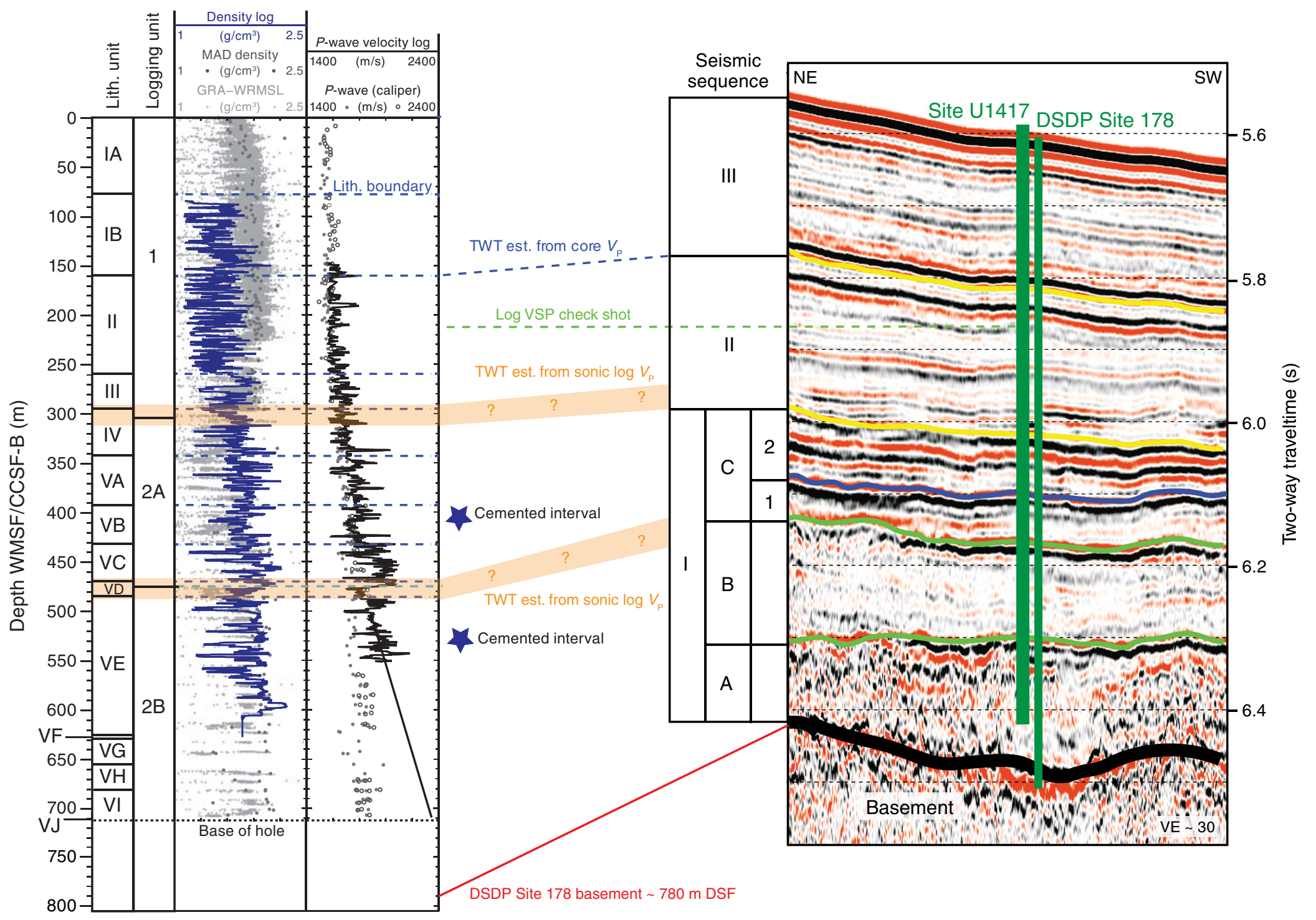


Figure F31. Physical properties measurements, Hole U1417A. WRMSL = Whole-Round Multisensor Logger, MS $=$ magnetic susceptibility $. \mathrm{MAD}=$ moisture and density, GRA = gamma ray attenuation $. \mathrm{NGR}=$ natural gamma radiation.

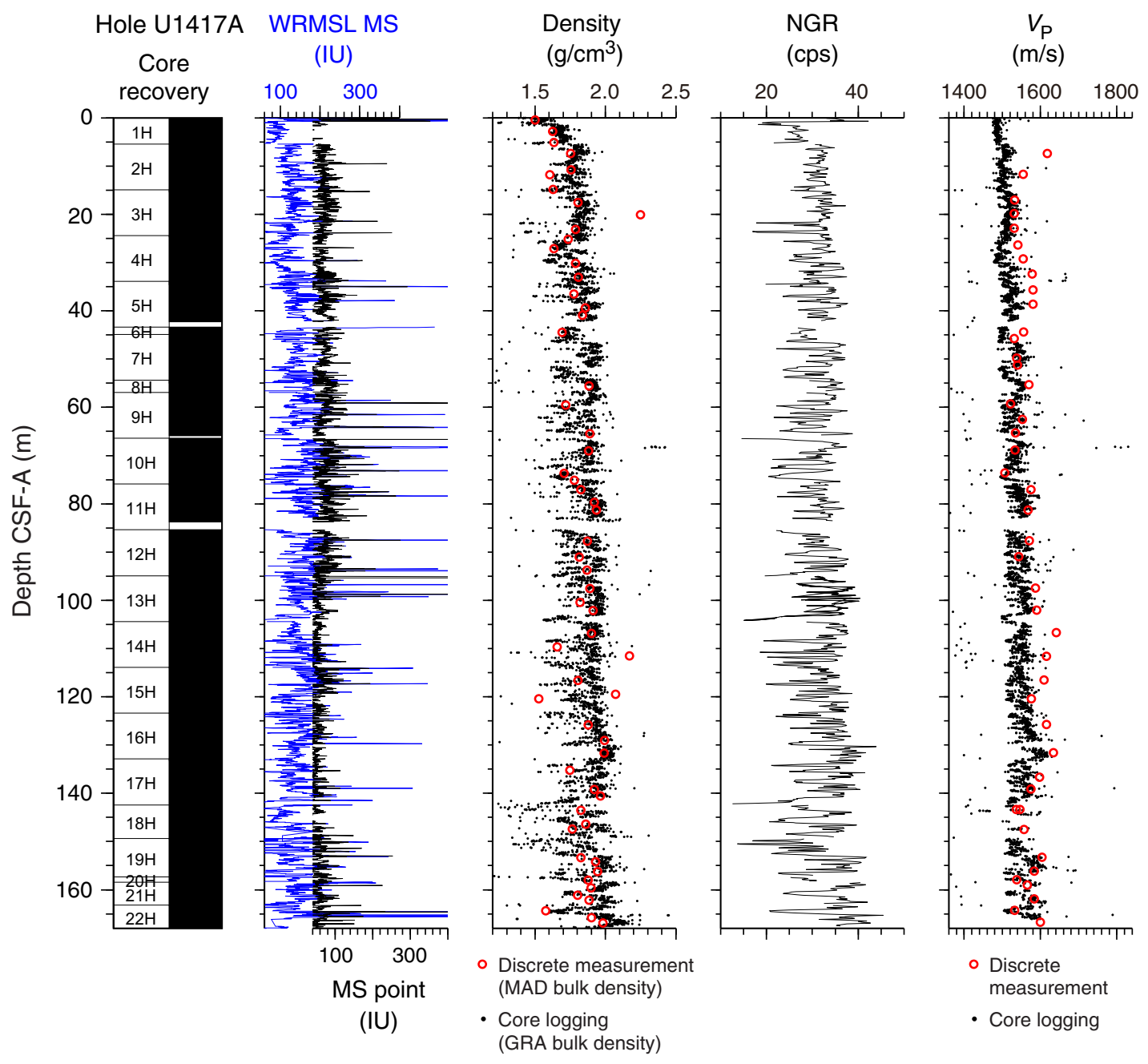


Figure F32. Physical properties measurements, Hole U1417B. WRMSL = Whole-Round Multisensor Logger, MS $=$ magnetic susceptibility. GRA = gamma ray attenuation. NGR = natural gamma radiation .

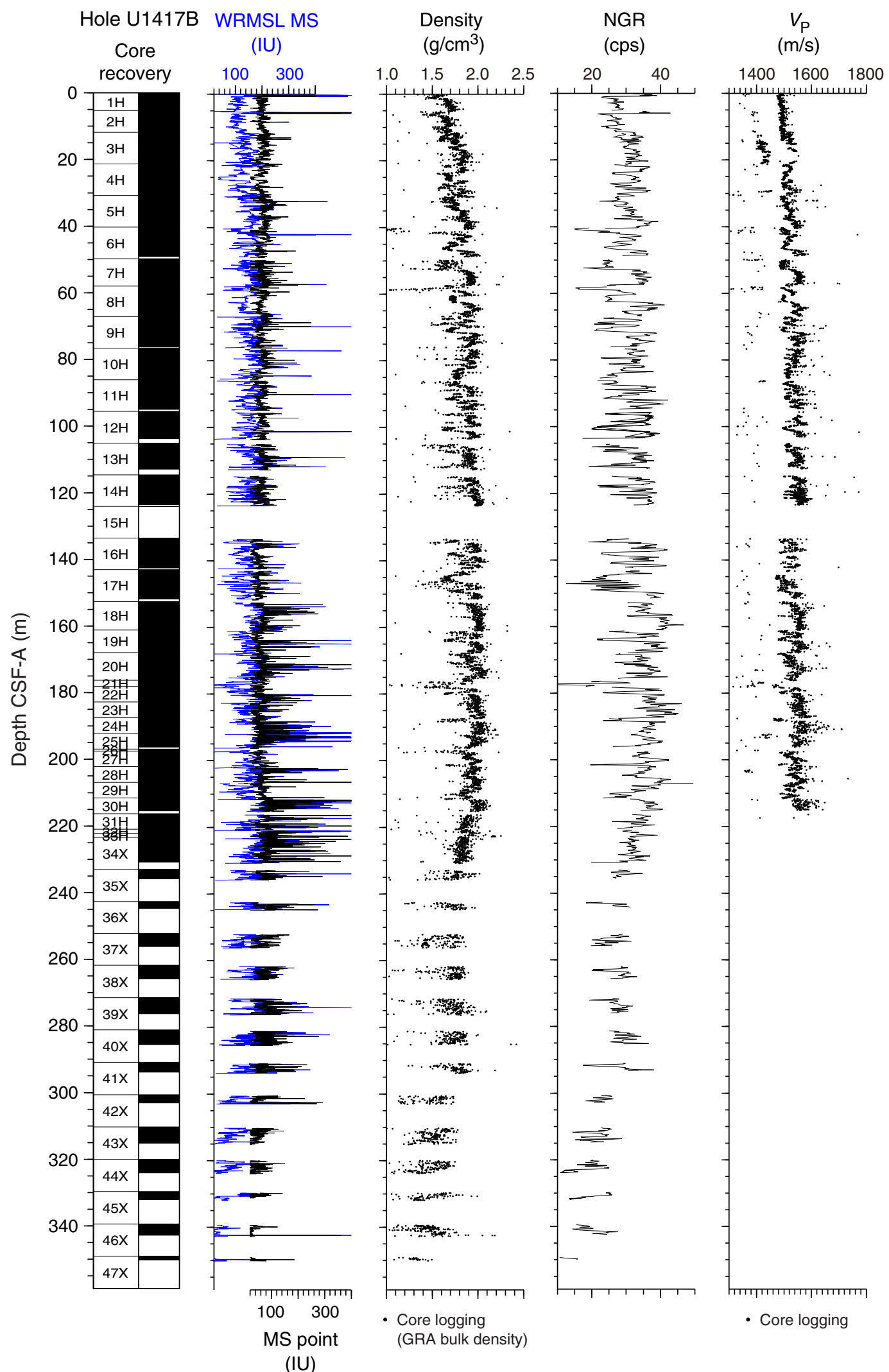


Figure F33. Physical properties measurements, Hole U1417C. WRMSL = Whole-Round Multisensor Logger, MS $=$ magnetic susceptibility. GRA = gamma ray attenuation. NGR = natural gamma radiation .

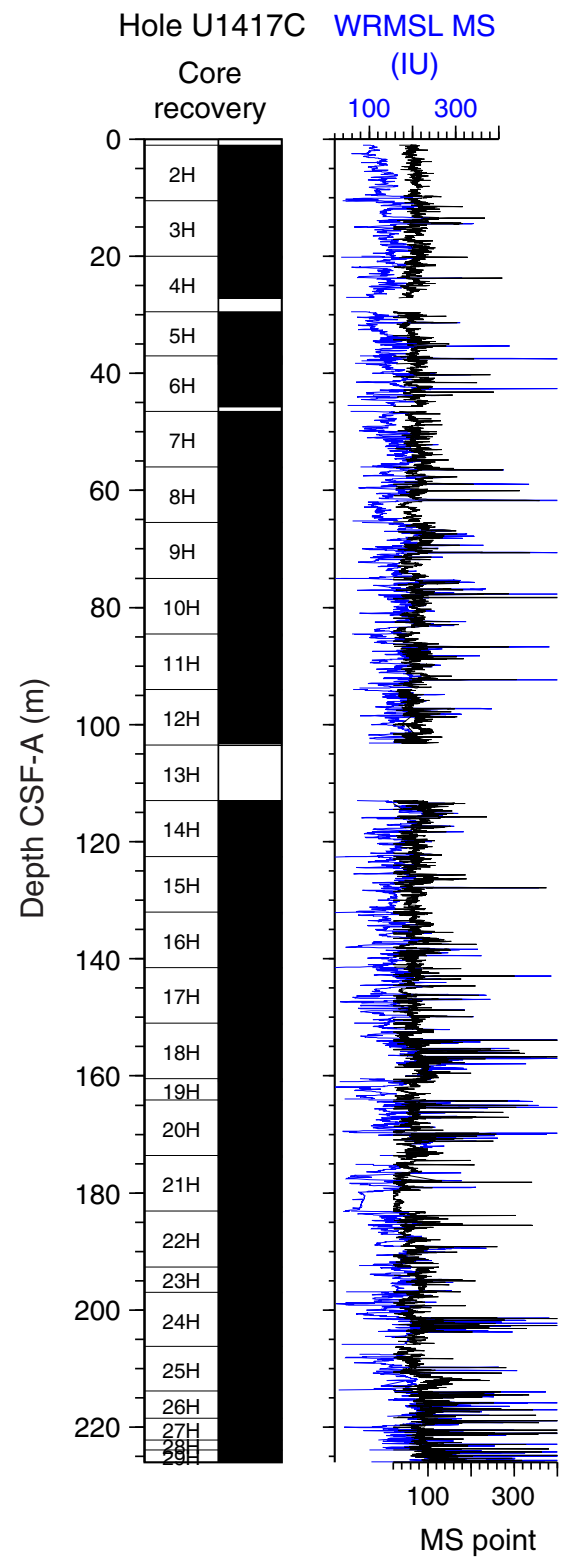

(IU)
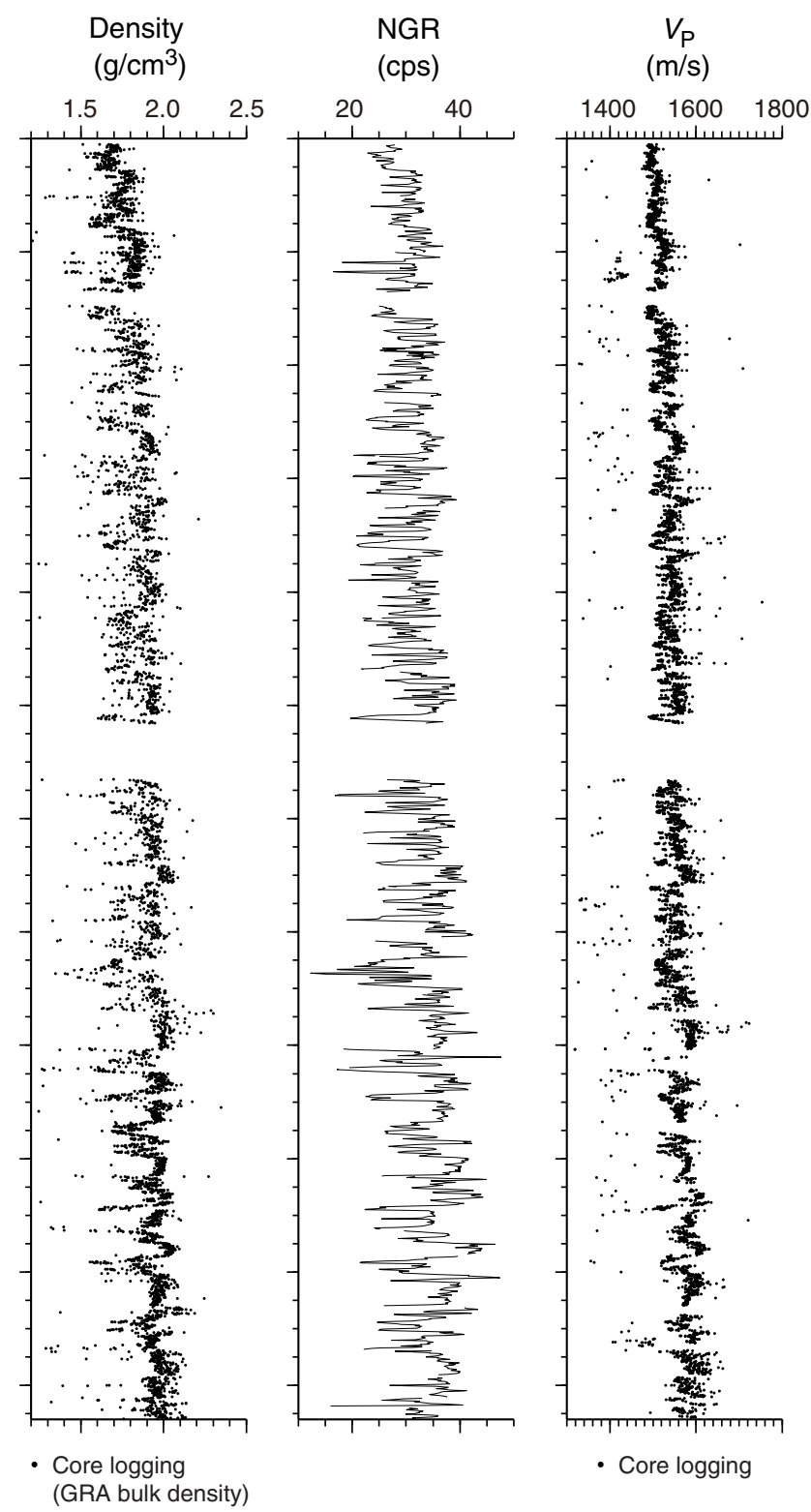
Figure F34. Physical properties measurements, Hole U1417D. WRMSL = Whole-Round Multisensor Logger, MS $=$ magnetic susceptibility $. \mathrm{MAD}=$ moisture and density, GRA = gamma ray attenuation $. \mathrm{NGR}=$ natural gamma radiation.

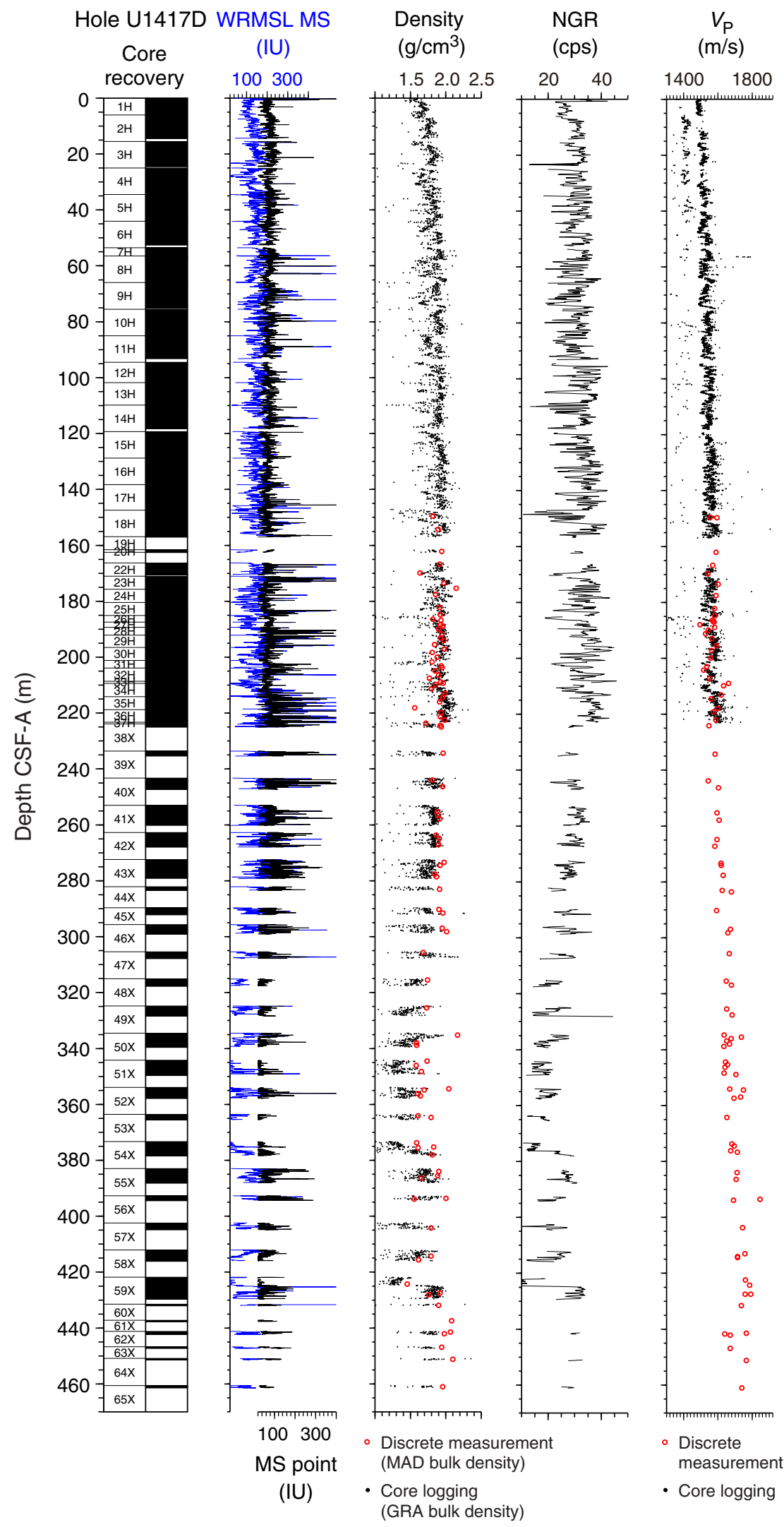


Figure F35. Physical properties measurements, Hole U1417E. WRMSL = Whole-Round Multisensor Logger, MS $=$ magnetic susceptibility. $\mathrm{MAD}=$ moisture and density, GRA = gamma ray attenuation. $\mathrm{NGR}=$ natural gamma radiation.

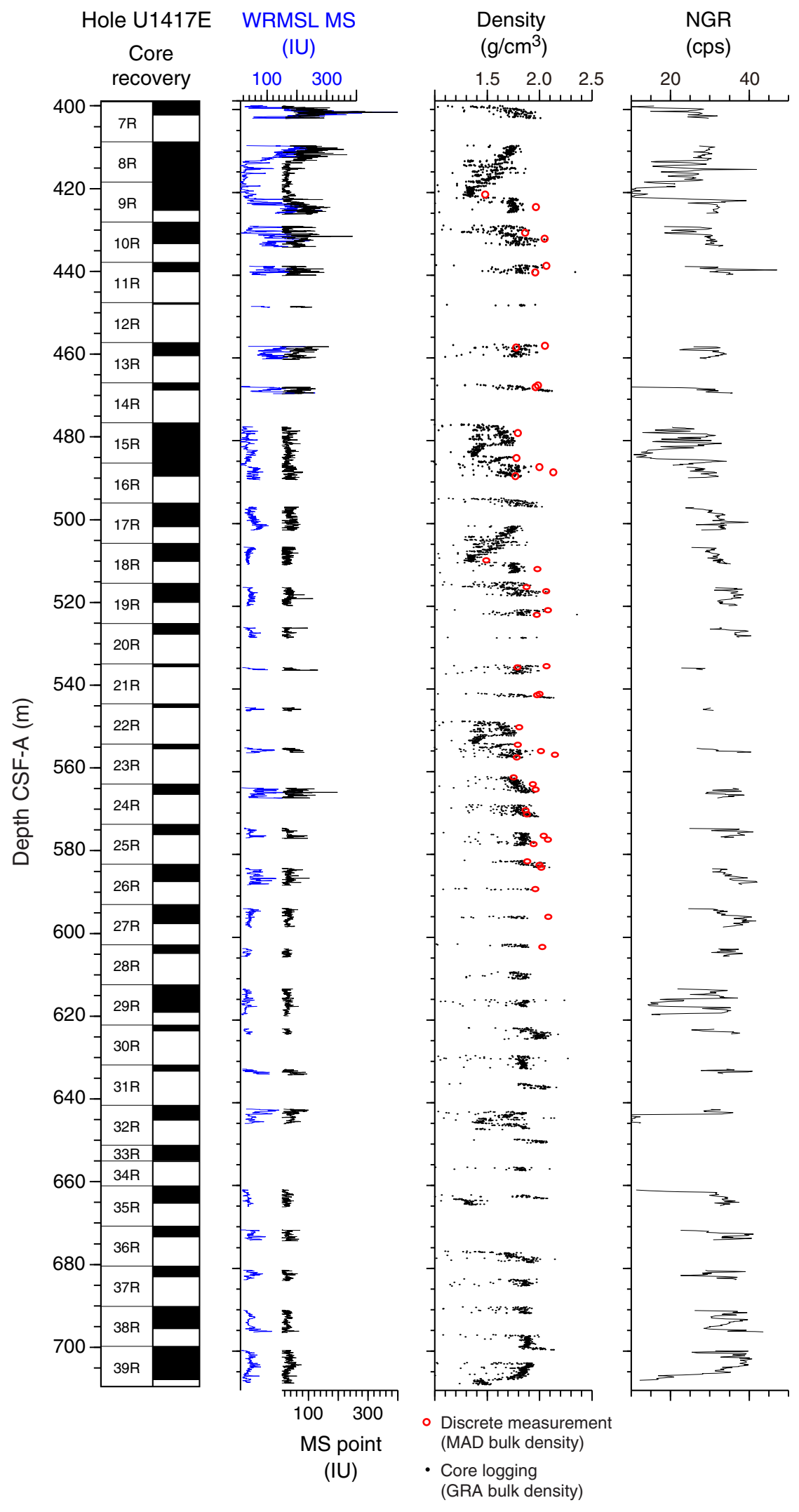


Figure F36. Discrete moisture and density (MAD) bulk sediment density measurements (dots) from Holes U1417A-U1417E compared to Whole-Round Multisensor Logger (WRMSL) gamma ray attenuation (GRA) bulk density measurements from equivalent depths in core. Diamonds denote measurements from APC-derived cores only.

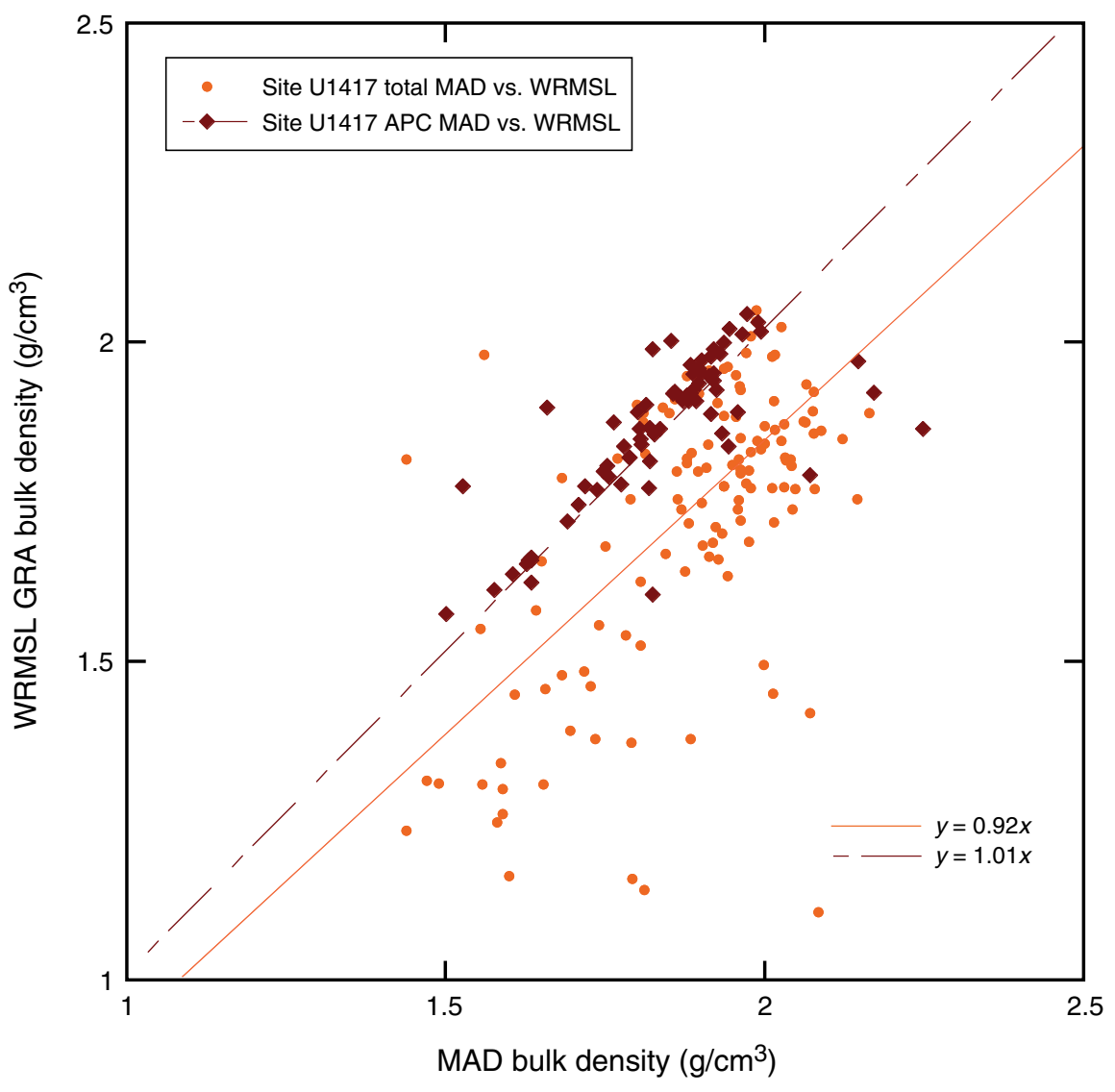


Figure F37. Point-source magnetic susceptibility (MS) data from the advanced piston corer portions of Holes U1417A-U1417D compared to Whole-Round Multisensor Logger (WRMSL) loop MS data from equivalent depths in those cores.

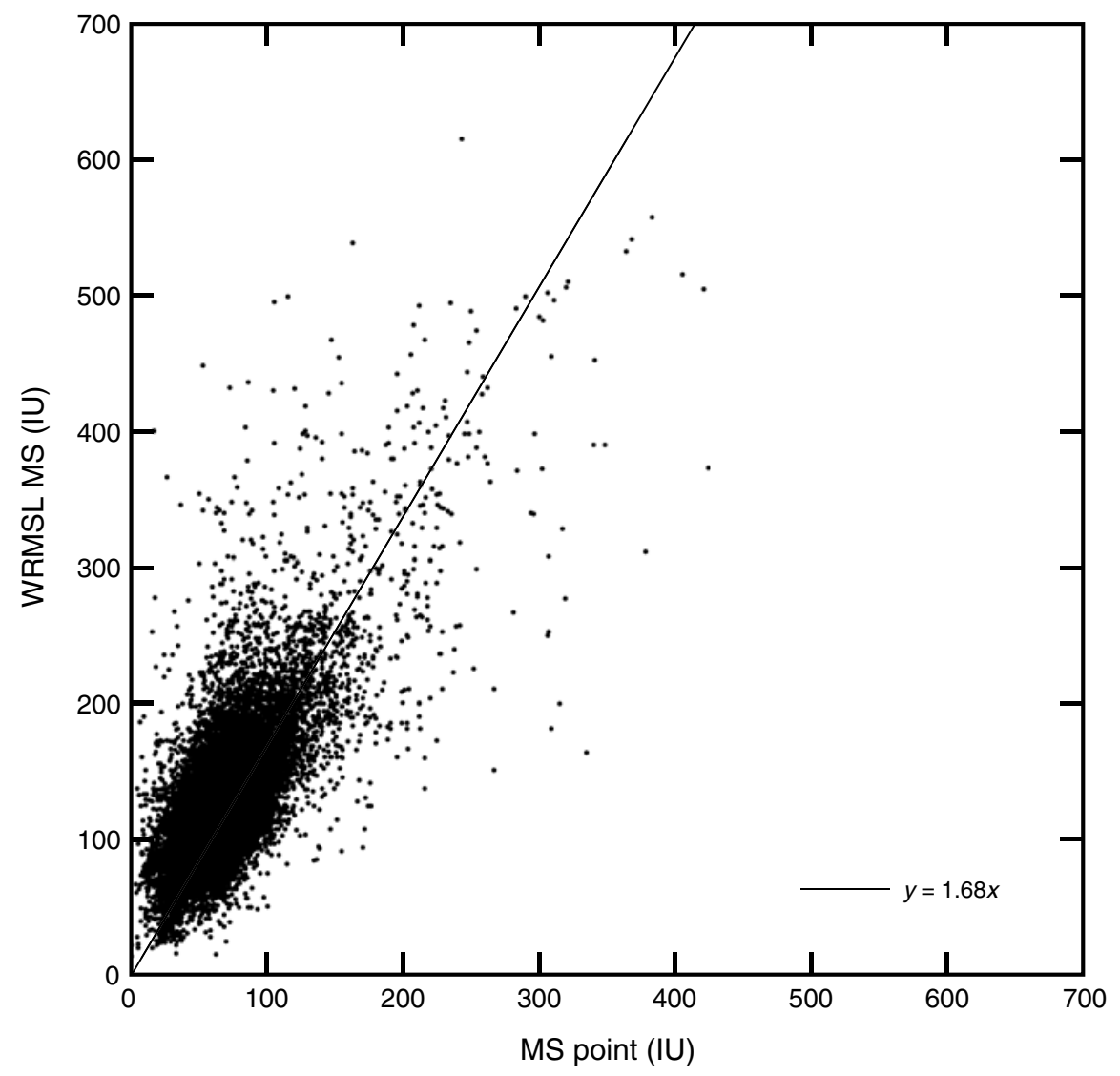


Figure F38. Whole-Round Multisensor Logger (WRMSL) gamma ray attenuation (GRA) bulk density compared to WRMSL magnetic susceptibility (MS) data, Site U1417. Both data sets are shown after Gaussian smoothing with a $10 \mathrm{~cm}$ window $( \pm 3 \sigma)$ and interpolation to constant resolution at $2.5 \mathrm{~cm}$. WRMSL MS ( $\kappa$, black) is also shown corrected for variability in recovered sediment volume by normalizing to WRMSL GRA bulk density $(\chi$, blue). Data in the upper $220 \mathrm{~m}$ CCSF-B reflect the stratigraphic composite splice (see "Stratigraphic correlation"); deeper than this point, data from XCB and RCB cores in Holes U1417B, U1417D, and U1417E are combined to form a single composite section. In this lower portion, we use an average of all available data at depths for which there are overlaps in recovery.

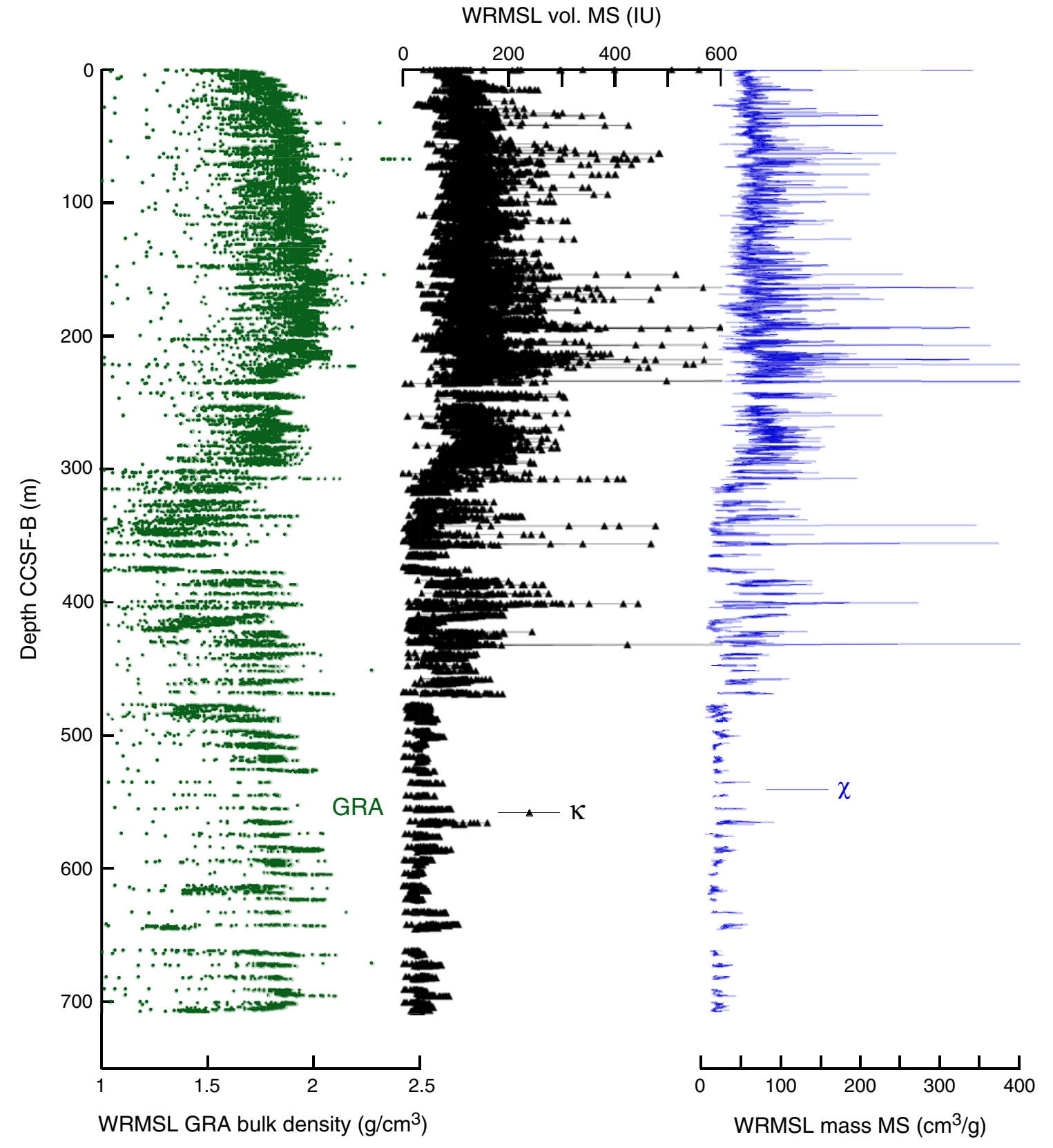


Figure F39. $P$-wave velocity measured by the WRMSL at $2.5 \mathrm{~cm}$ resolution, Holes U1417A-U1417D.

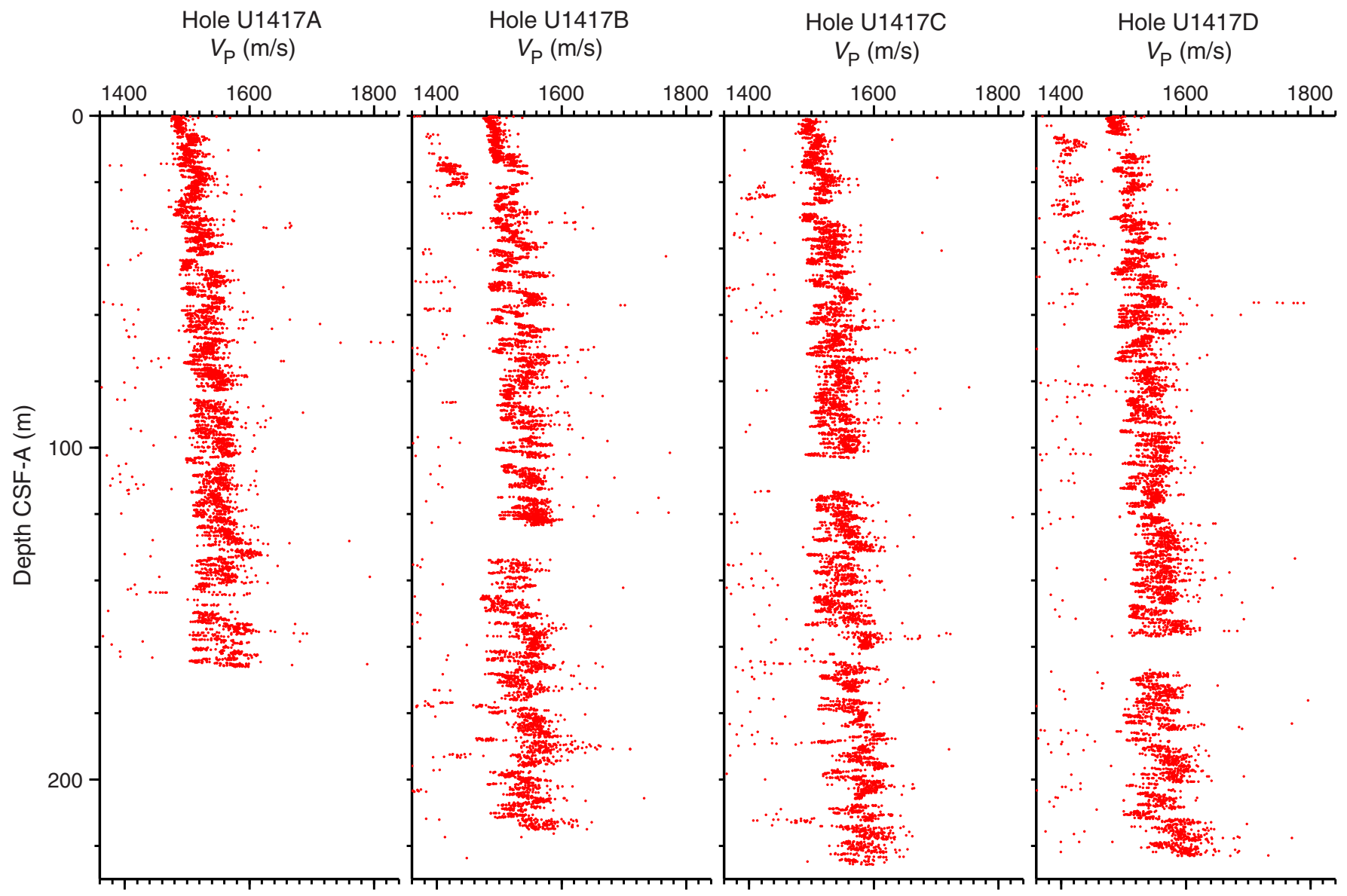


Figure F40. $P$-wave velocity measured by the Whole-Round Multisensor Logger (WRMSL) on whole-round sections and the $P$-wave caliper (PWC) on working half sections. A. Combined plot. B. Scatter plot, showing correlation between core logger and discrete measurements. The black trend line reflects all values from Holes U1417A and U1417D.

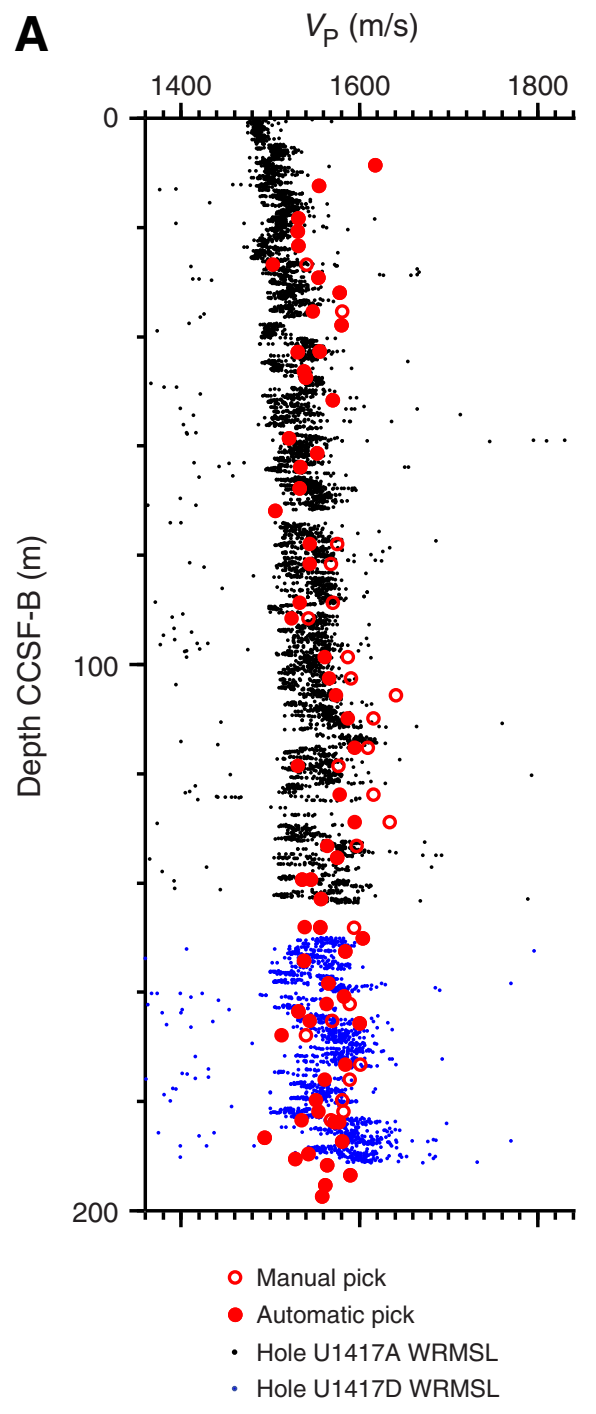

B

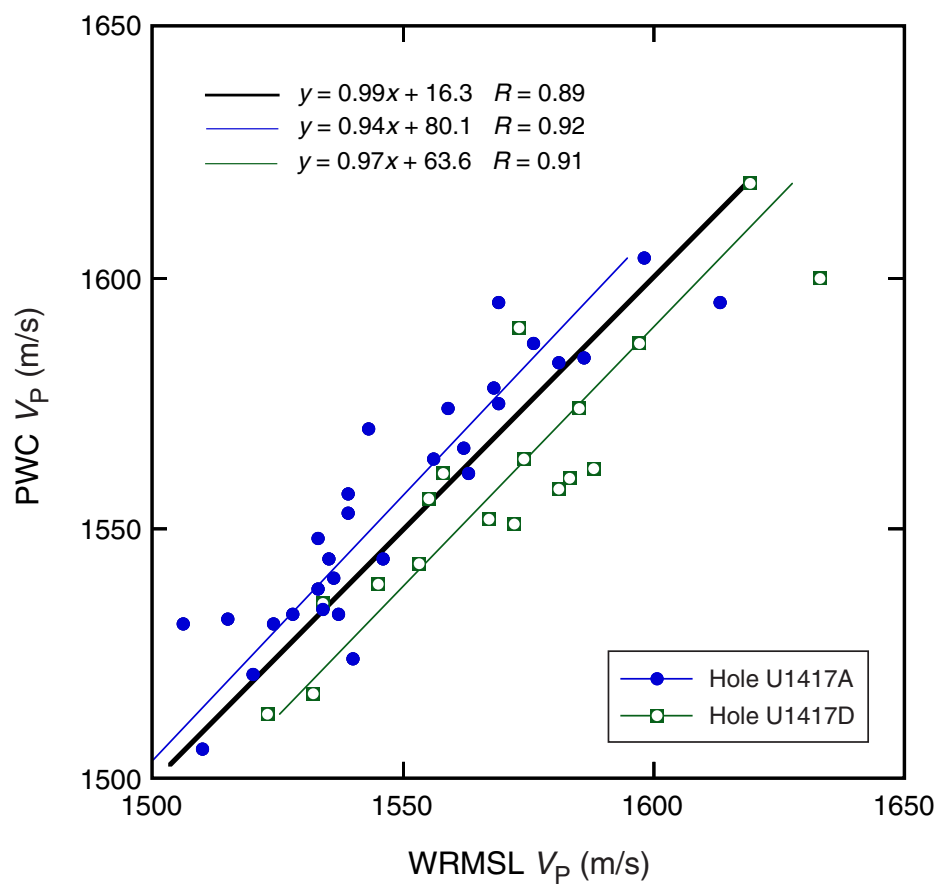


Figure F41. $P$-wave velocity measured by the $P$-wave caliper, Holes U1417A, U1417D, and U1417E. Left: velocities between 1450 and $1980 \mathrm{~m} / \mathrm{s}$. Right: velocities between 1480 and $6000 \mathrm{~m} / \mathrm{s}$.

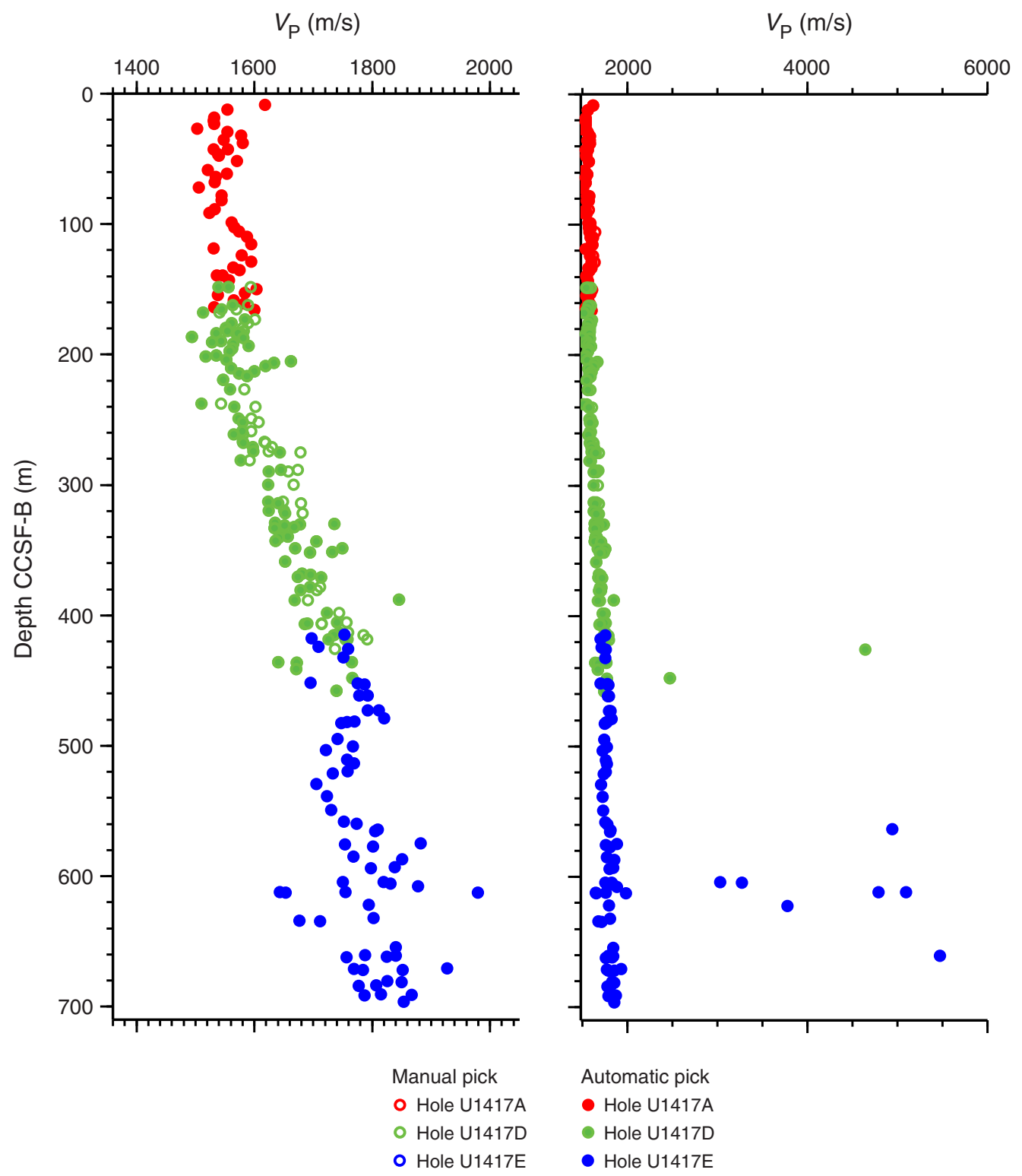


Figure F42. Whole-Round Multisensor Logger (WRMSL) gamma ray attenuation (GRA) bulk density compared to natural gamma radiation (NGR) data, Site U1417. Both data sets are shown after Gaussian smoothing with a $50 \mathrm{~cm}$ window $( \pm 3 \sigma)$ and interpolation to constant resolution at $10 \mathrm{~cm}$. NGR is also shown corrected for variability in recovered sediment volume by normalizing to WRMSL GRA bulk density. Data in the upper $220 \mathrm{~m}$ CCSF-B reflect the stratigraphic composite splice (see "Stratigraphic correlation"); data from deeper than 220 $\mathrm{m}$ CCSF-B obtained from XCB and RCB cores in Holes U1417B, U1417D, and U1417E are combined to form a single composite section. In this lower portion, we use an average of all available data at depths for which there are overlaps in recovery.

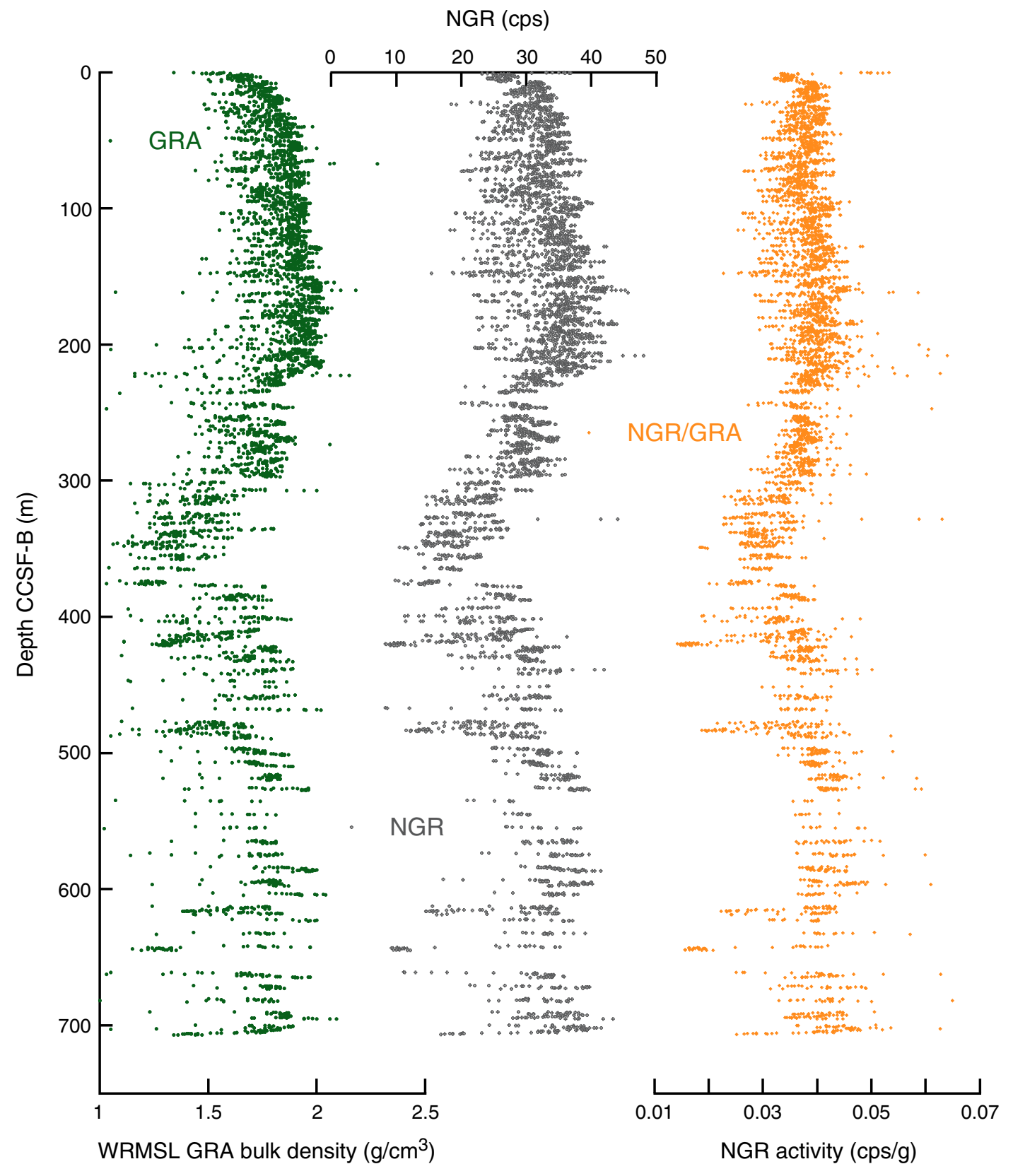


Figure F43. GRA bulk density data measured on the WRMSL (dots) vs. discrete wet bulk density data (circles), Holes U1417A, U1417D, and U1417E.

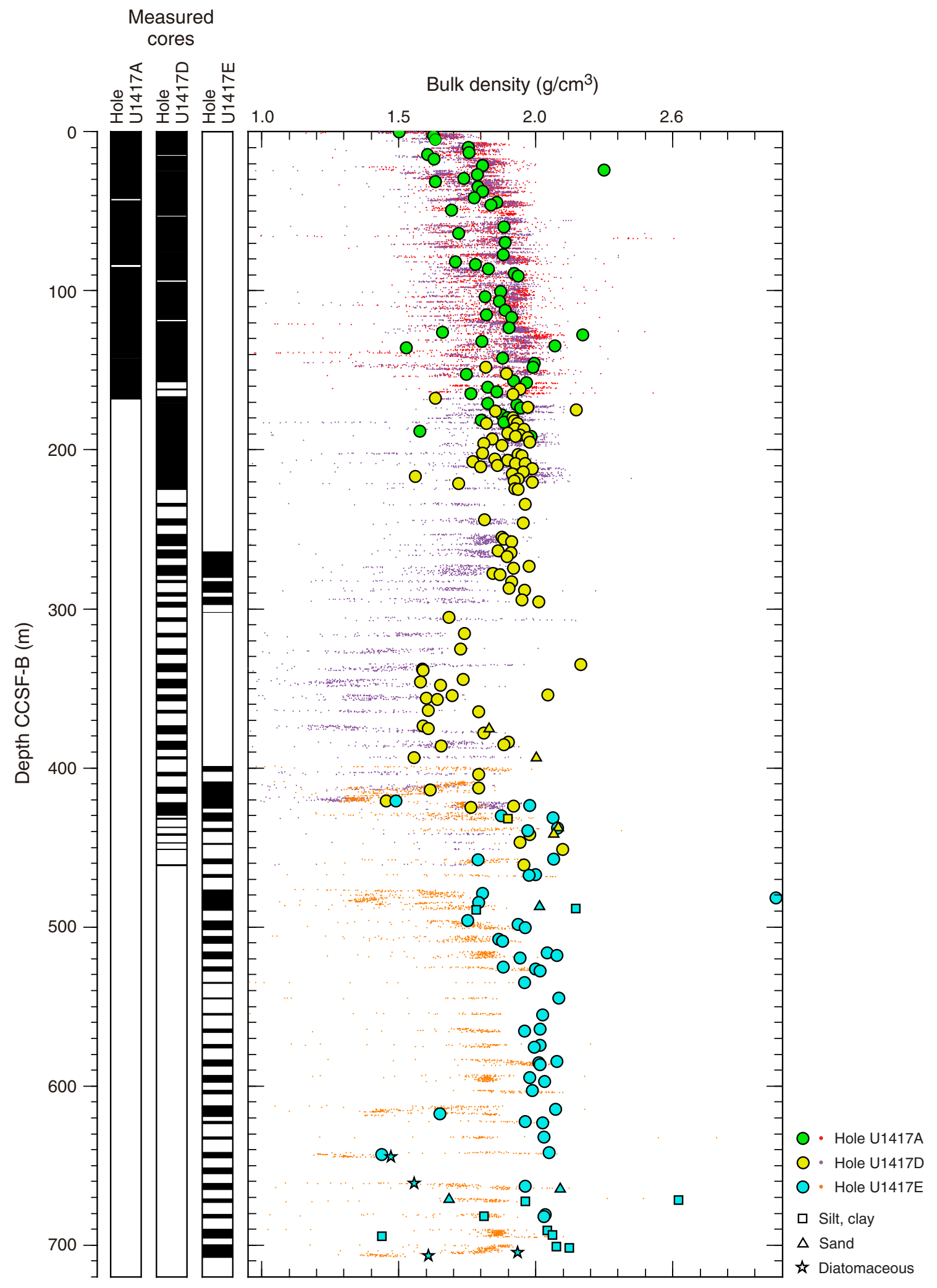


Figure F44. Bulk density, grain density, porosity, and void ratio measured using the moisture and density method, Holes U1417A, U1417D, and U1417E. Circles denote measurements without a denoted lithology, reflecting sampling of the major lithofacies (gray-green mud; see "Lithostratigraphy").

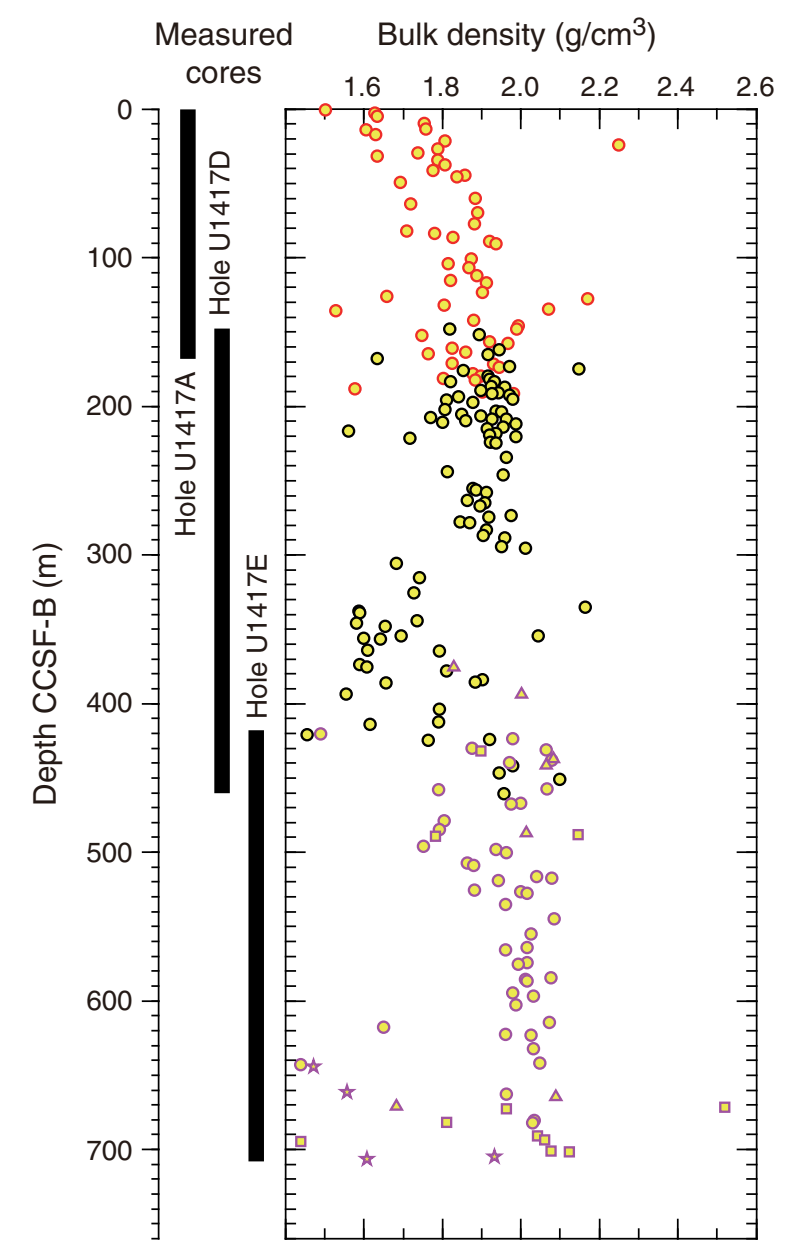

Grain density $\left(\mathrm{g} / \mathrm{cm}^{3}\right)$

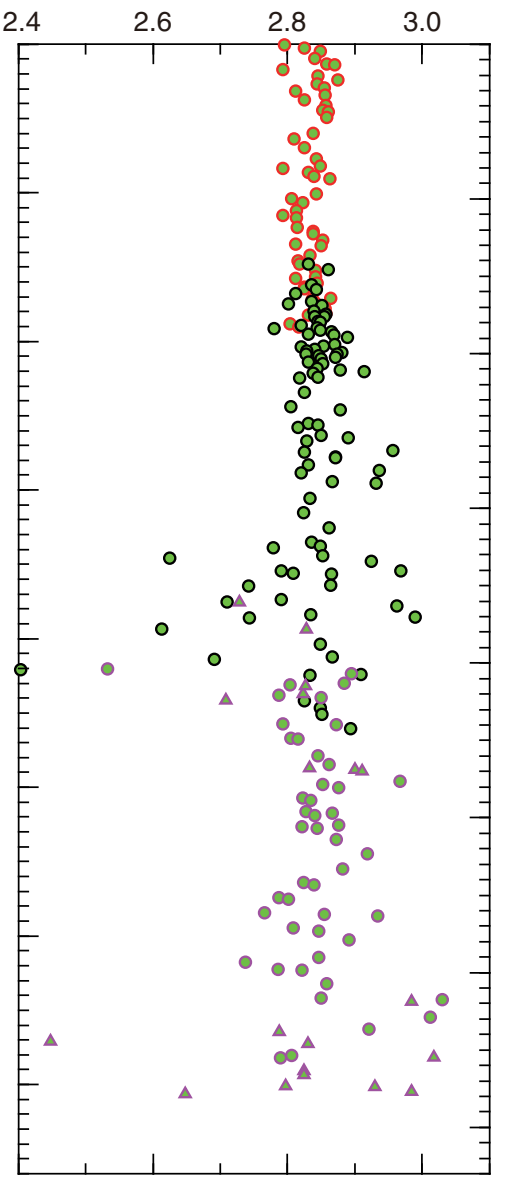

○ Hole U1417A

口 Silt, clay
○ Hole U1417D

$$
\Delta \text { Sand }
$$

\begin{abstract}
Porosity (vol\%)
\end{abstract}

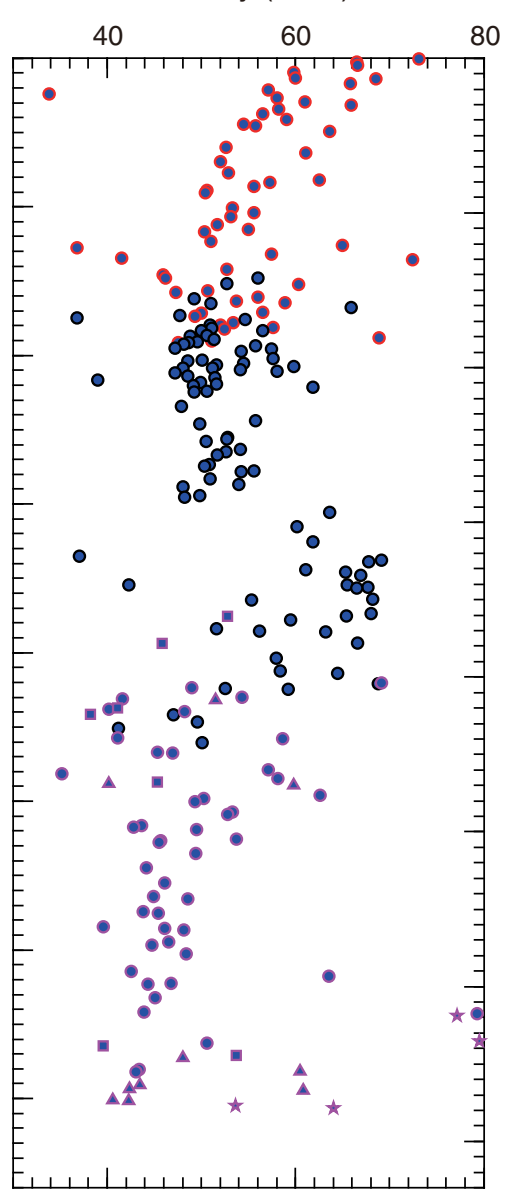

○ Hole U1417E

^ Diatomaceous

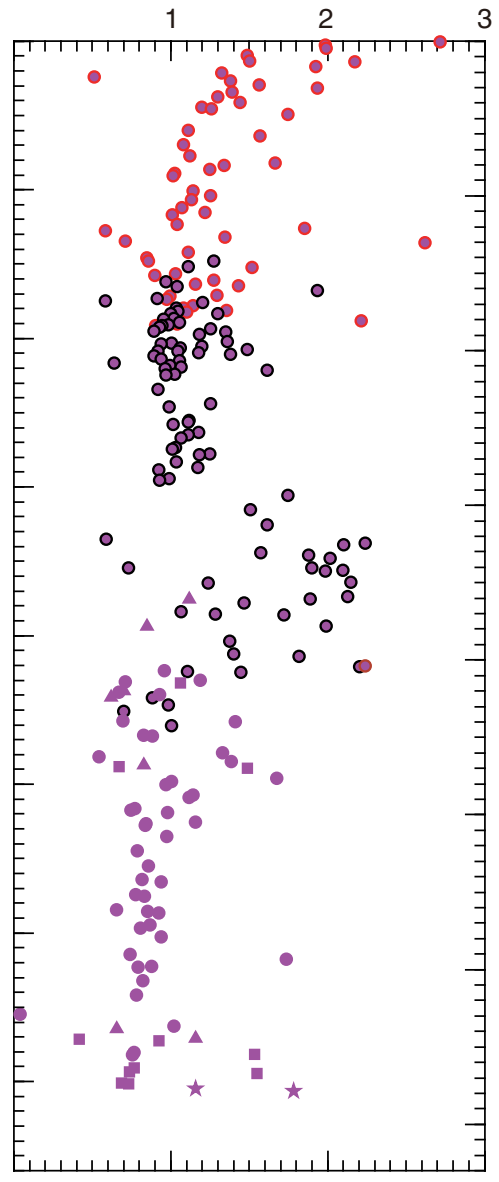


Figure F45. Shear strength values measured by the automatic vane shear system from Holes U1417A and U1417D.

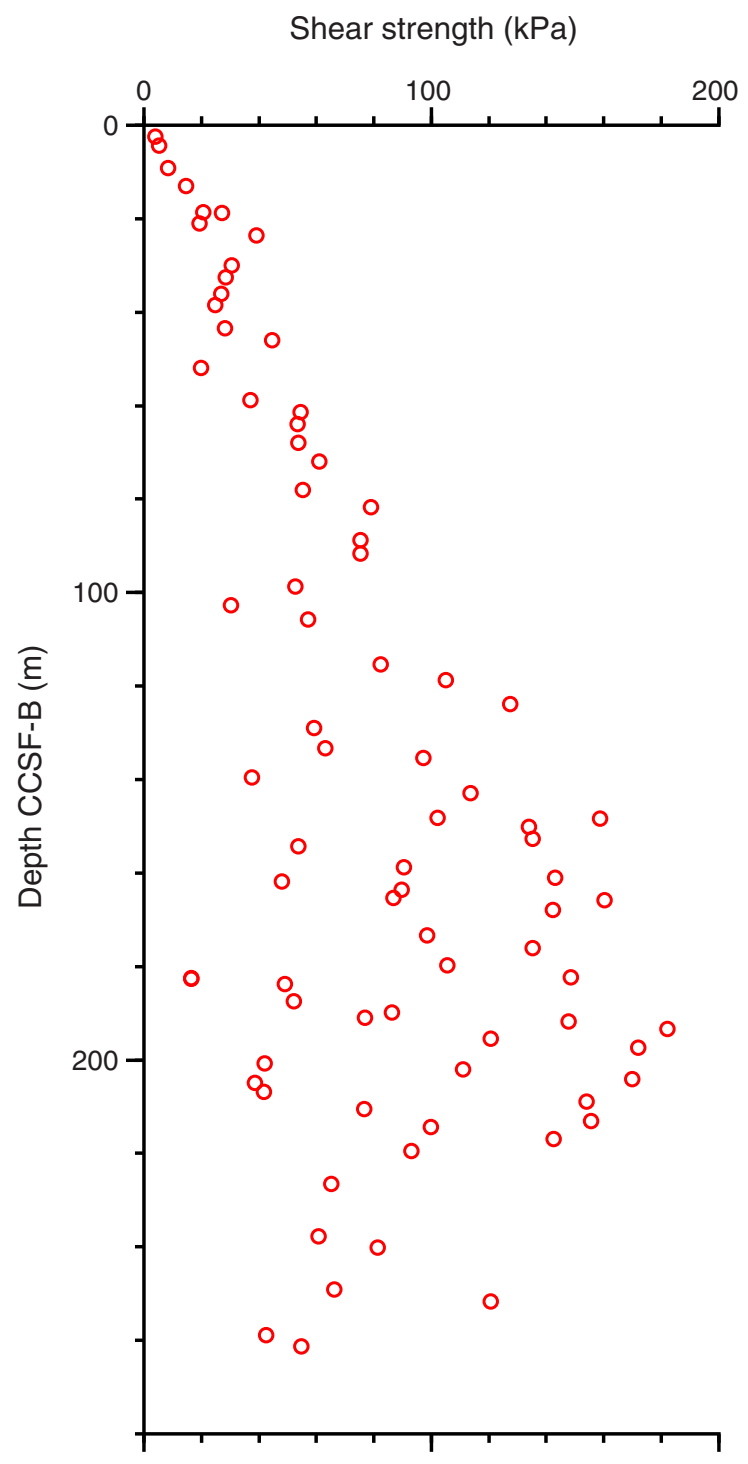


Figure F46. A. Temperature data from the advanced piston corer temperature tool, Cores 341-U1417-4H, 10H, and 13H. An exponential decrease in temperature is expected for the time interval shown and was used to estimate ambient temperature. Data for the time interval $t_{\mathrm{i}}$ to $t_{\mathrm{f}}$ (solid circles) were used to estimate asymptotic temperature. B. Resulting geothermal gradient $\left(61^{\circ} \mathrm{C} / \mathrm{km}\right)$.

A

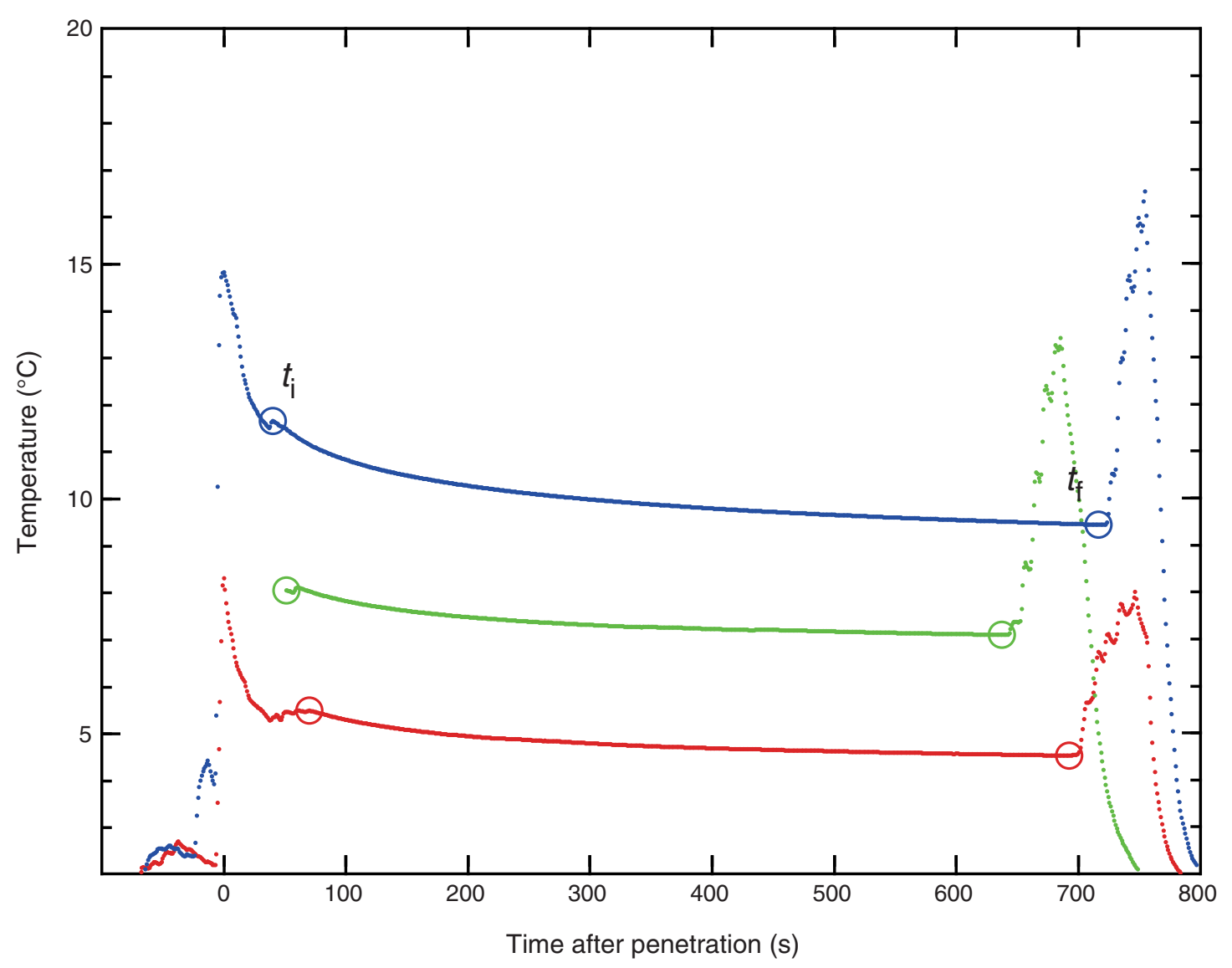

B

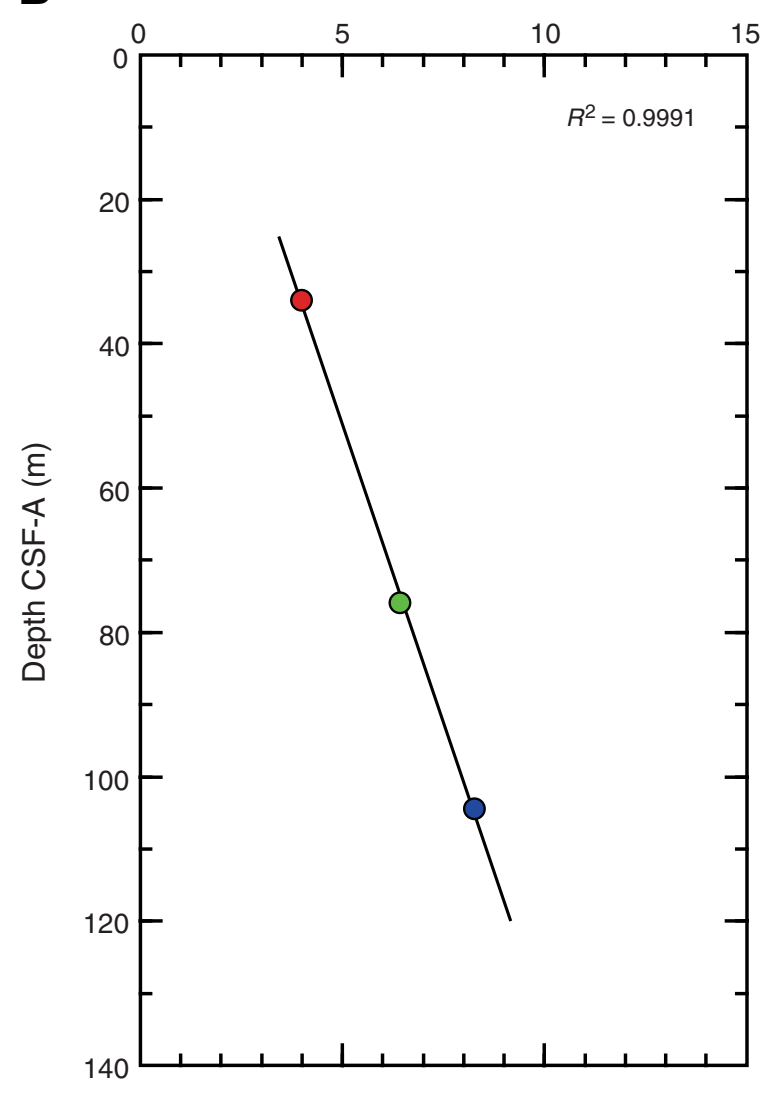


Figure F47. Natural remanent magnetization intensity measured before and after 10 and $20 \mathrm{mT}$ peak alternating field demagnetization in the recovered APC interval, Site U1417. Polarity interpretation and correlation to the geomagnetic polarity timescale (GPTS) on the geological timescale (Hilgen et al., 2012) is developed in the text (see "Paleomagnetism") and in Figure F49.
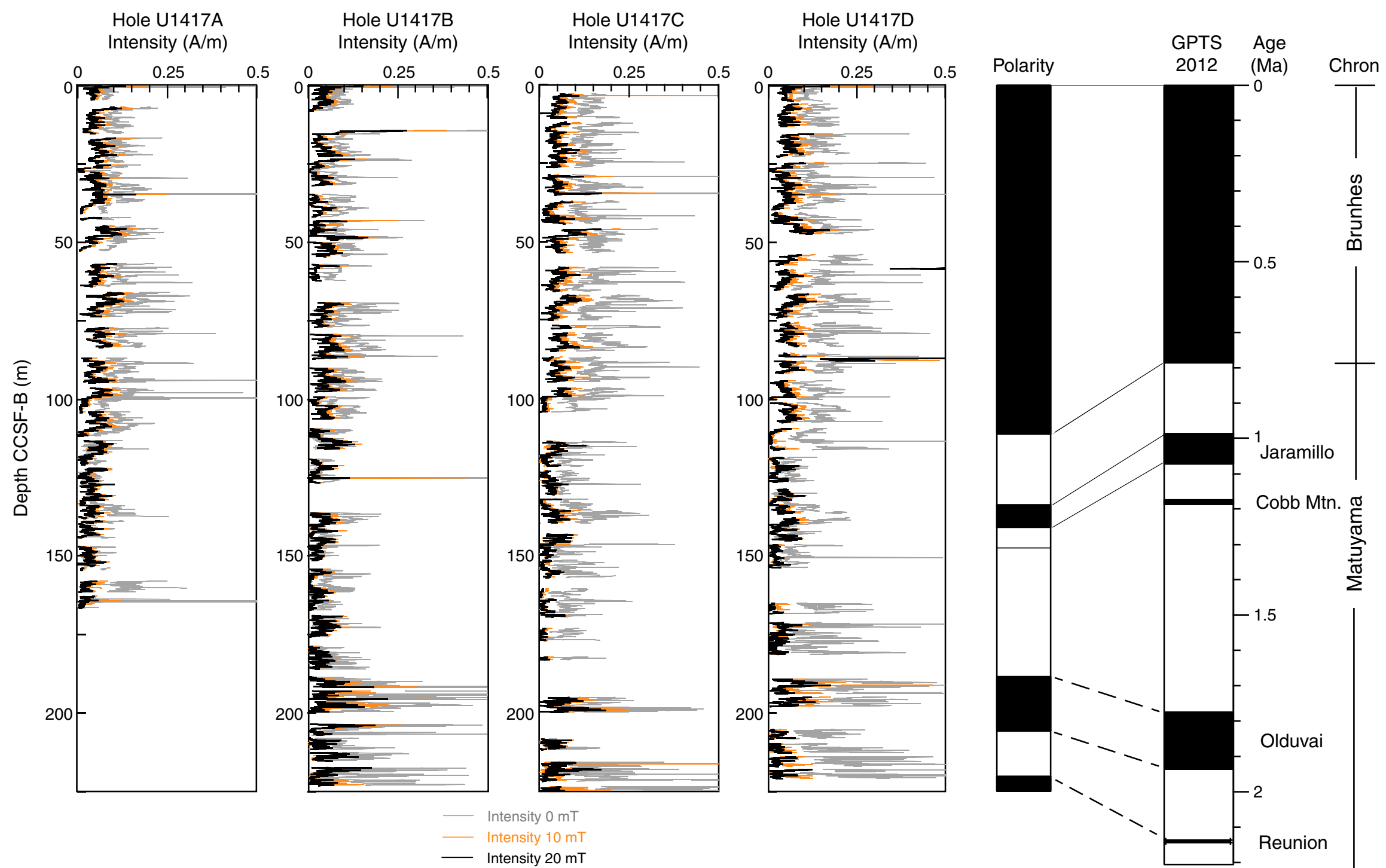
Figure F48. Natural remanent magnetization intensity plotted on a log scale before and after $20 \mathrm{mT}$ peak alternating field demagnetization in recovered APC, XCB, and RCB intervals, Site U1417.
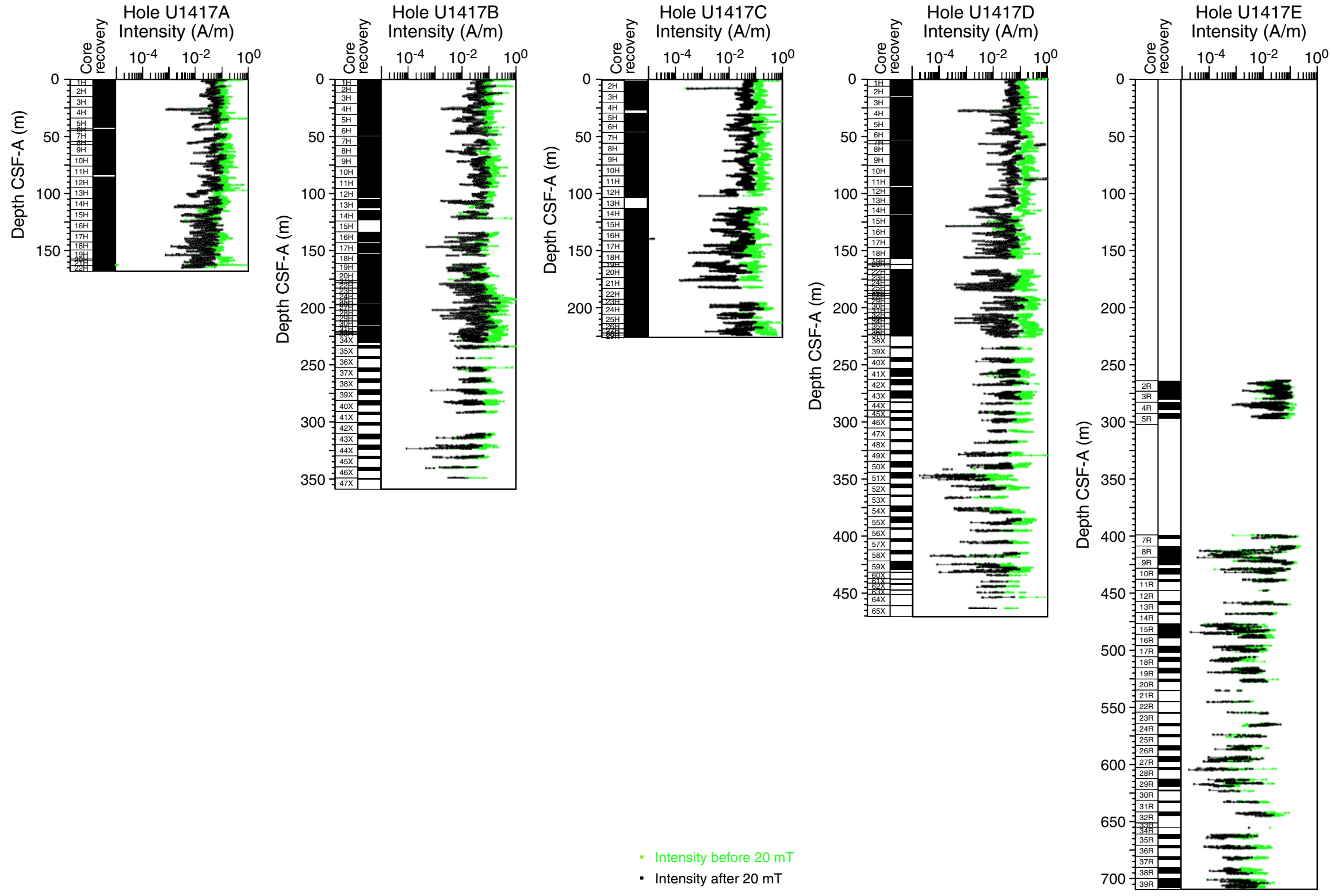
Figure F49. Inclination and polarity interpretations before and after peak alternating field demagnetization at $20 \mathrm{mT}$ in recovered APC intervals, Site U1417. Polarity interpretation and correlation to the geomagnetic polarity timescale (GPTS) on the geological timescale (Hilgen et al., 2012) is shown and developed in the text (see "Paleomagnetism").
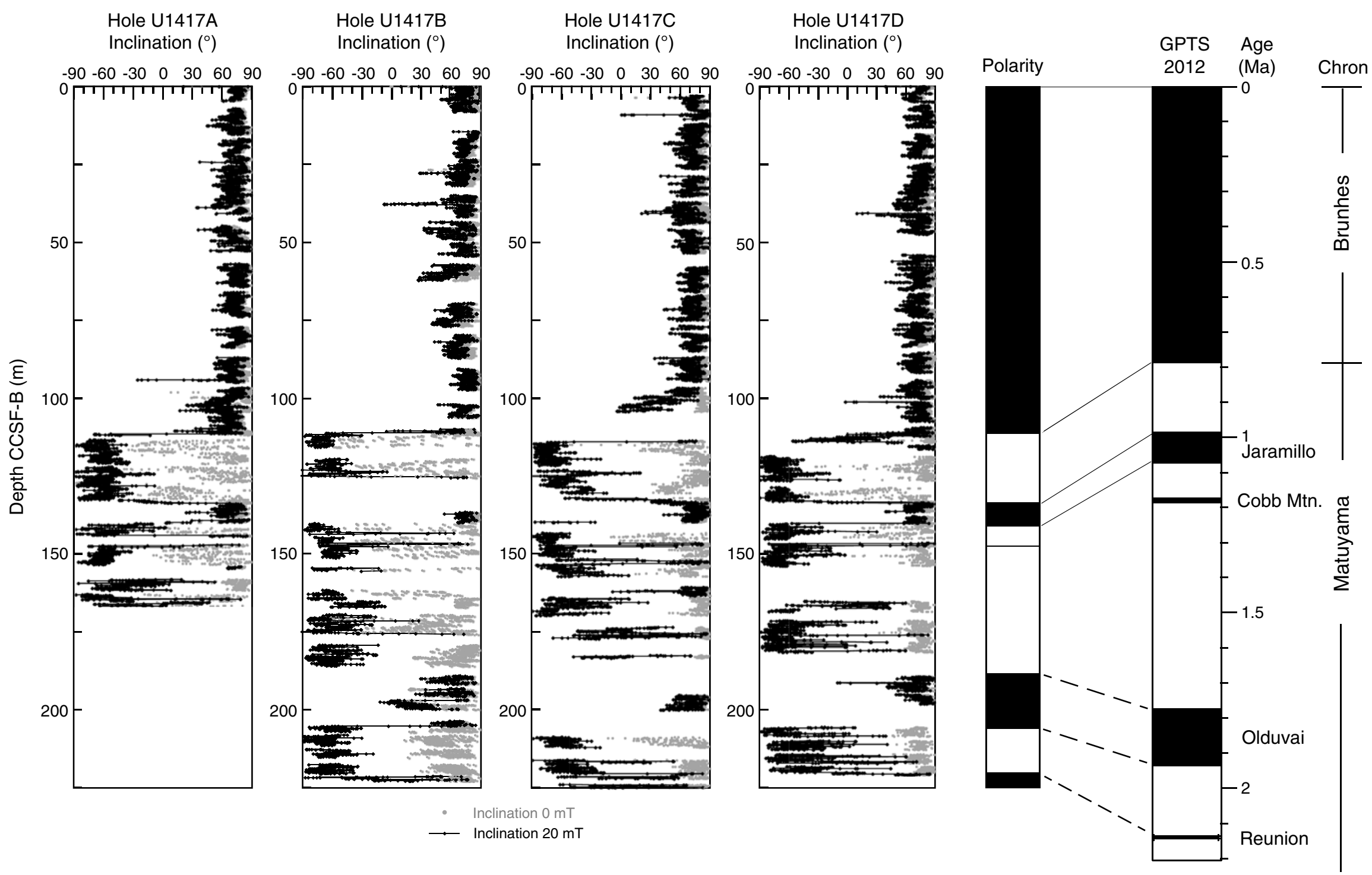
Figure F50. Inclination and polarity interpretations after peak alternating field demagnetization $(20,30$, or 40 $\mathrm{mT}$ ) in recovered XCB intervals of Holes U1417B and U1417D, and the recovered RCB interval of Hole U1417E. The smoothed line (50 cm running mean) is derived from expanded data that attempts to account for poor core recovery. See "Paleomagnetism" for explanation of expansion methodology. The geomagnetic polarity timescale (GPTS) on the geological timescale is shown for reference (Hilgen et al., 2012).

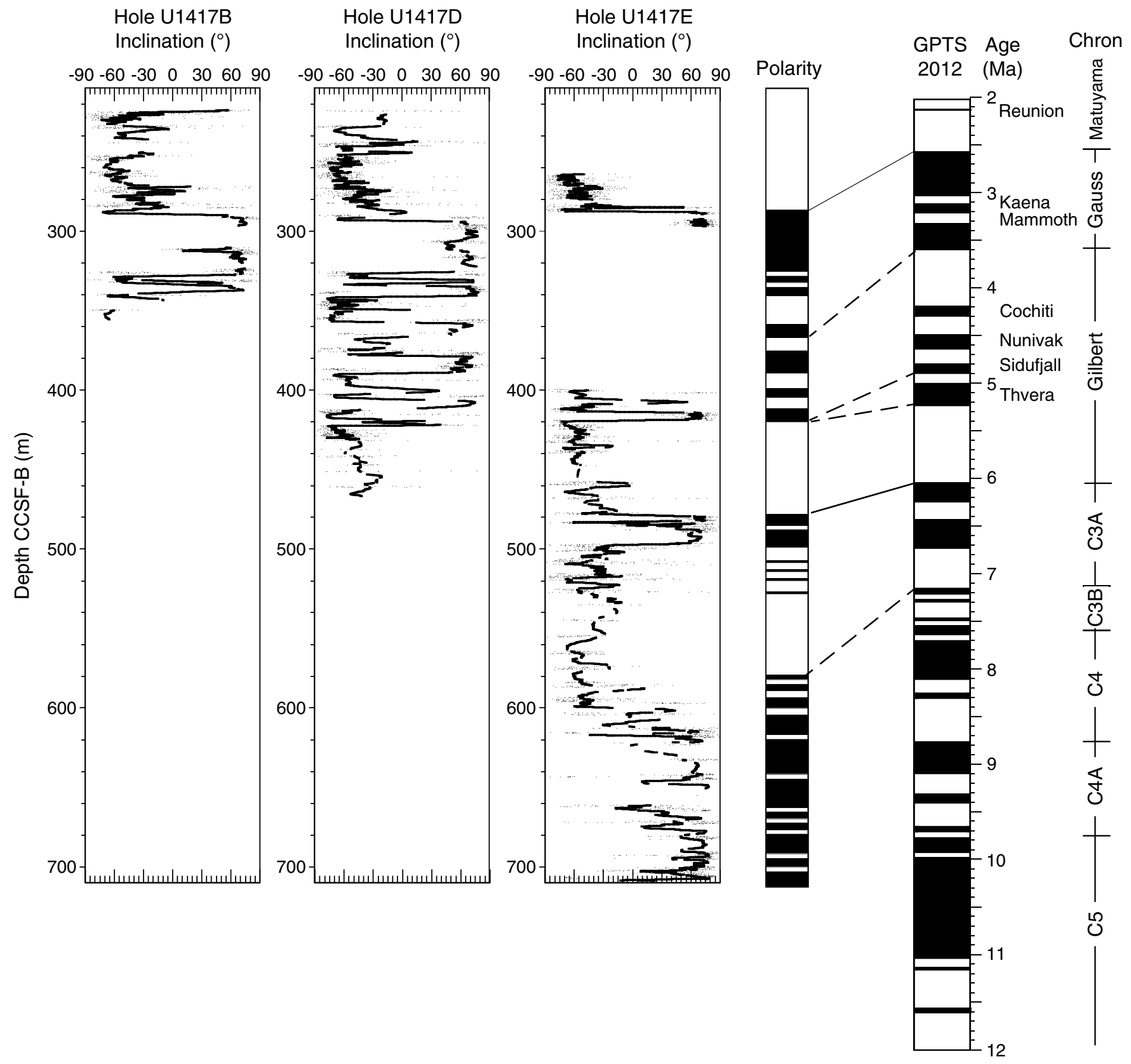


Figure F51. Logging operations summary diagram for Hole U1417E, showing wireline depths reached during different logging passes and borehole depths. See Table T6 in the "Methods" chapter (Jaeger et al., 2014) for definitions of depth scales. FMS = Formation MicroScanner, MSS = Magnetic Susceptibility Sonde. Star = depth of stations that yielded good first arrival times in vertical seismic profile (VSP).

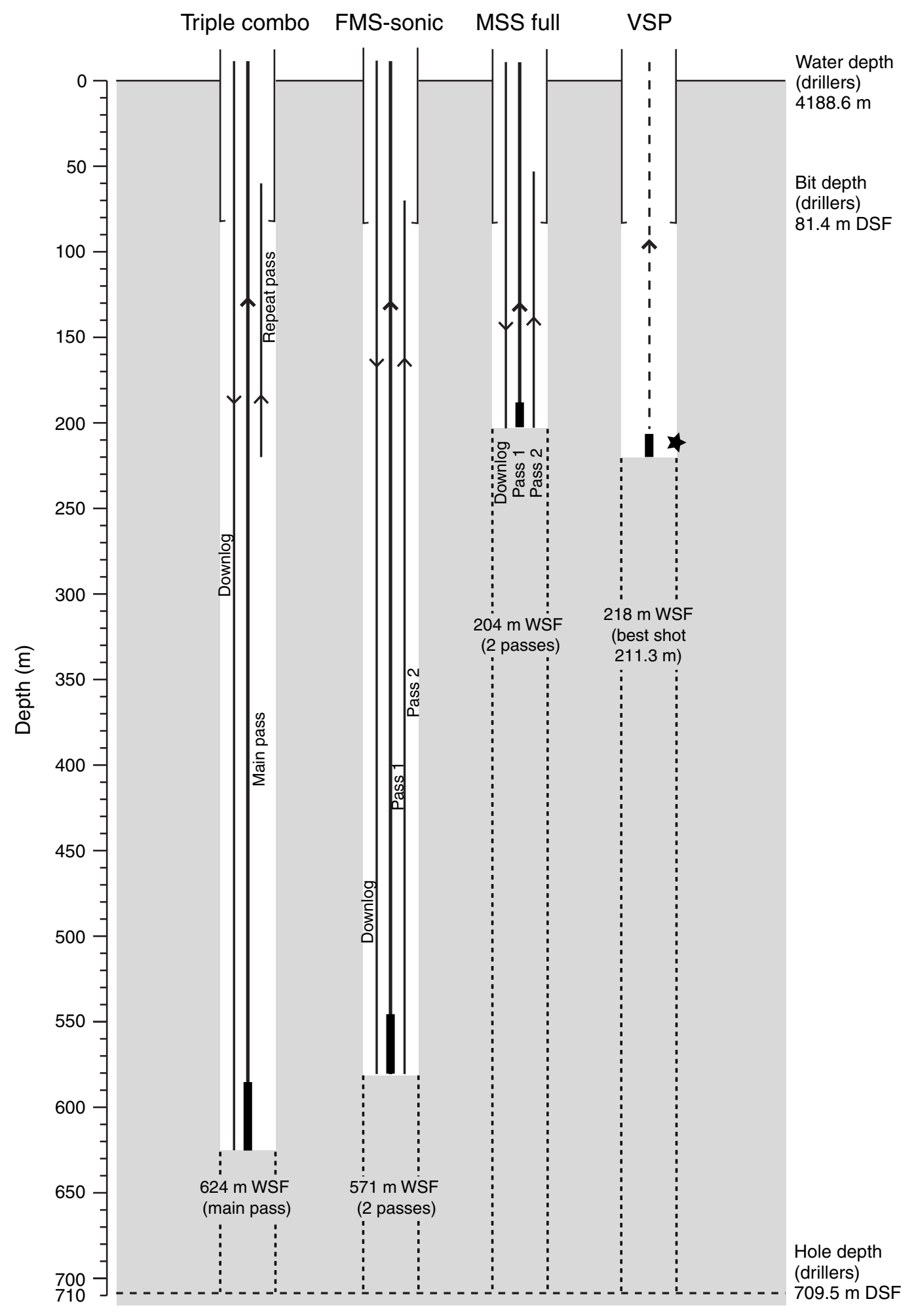


Figure F52. Summary of logs from the triple combo tool string and logging units, Hole U1417E. Core data are plotted in CSF-A: NGR = natural gamma radiation (gray $=$ Hole U1417D, green $=$ Hole U1417E), MAD = moisture and density (open symbols $=$ Hole U1417D, solid symbols = Hole U1417E). Resistivity: R3 = medium resistivity reading of High-Resolution Laterolog Array, R5 = deepest resistivity, RT = true resistivity modeled from all depths.

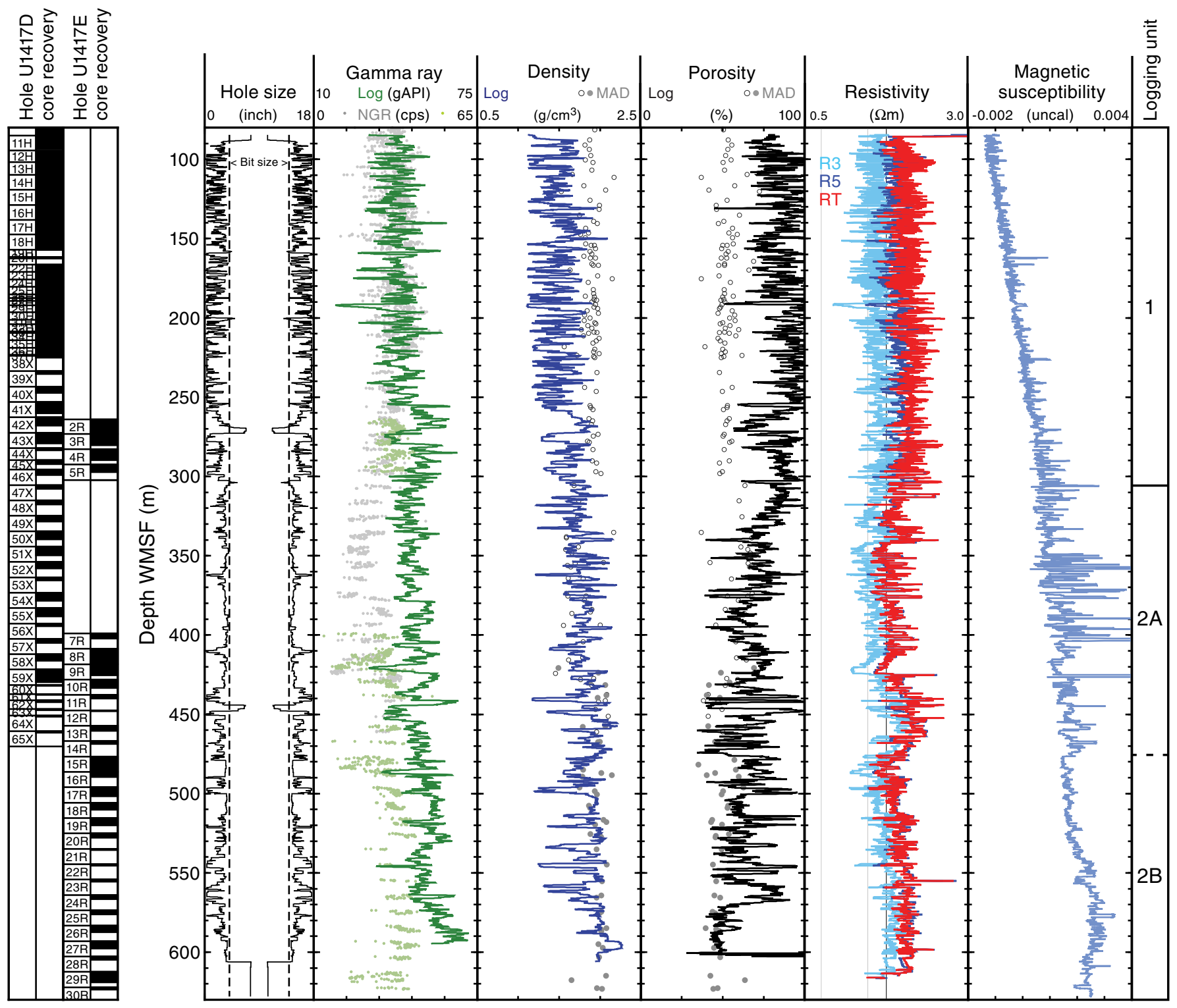


Figure F53. Summary of logs from Pass 2 of the Formation MicroScanner (FMS)-sonic tool string and logging units, Hole U1417E. Hole size is measured by the two orthogonal calipers of the FMS (C1 and C2). Waveform coherence in the velocity tracks is a measure of the reliability of the slowness/time coherence algorithm used to derive compressional $\left(V_{\mathrm{P}}\right)$ and shear $\left(V_{S}\right)$ velocities from monopole and lower dipole sonic waveforms, respectively. Particularly below $\sim 305 \mathrm{~m}$ WMSF, $V_{\mathrm{P}}$ shows similar trends to resistivity.

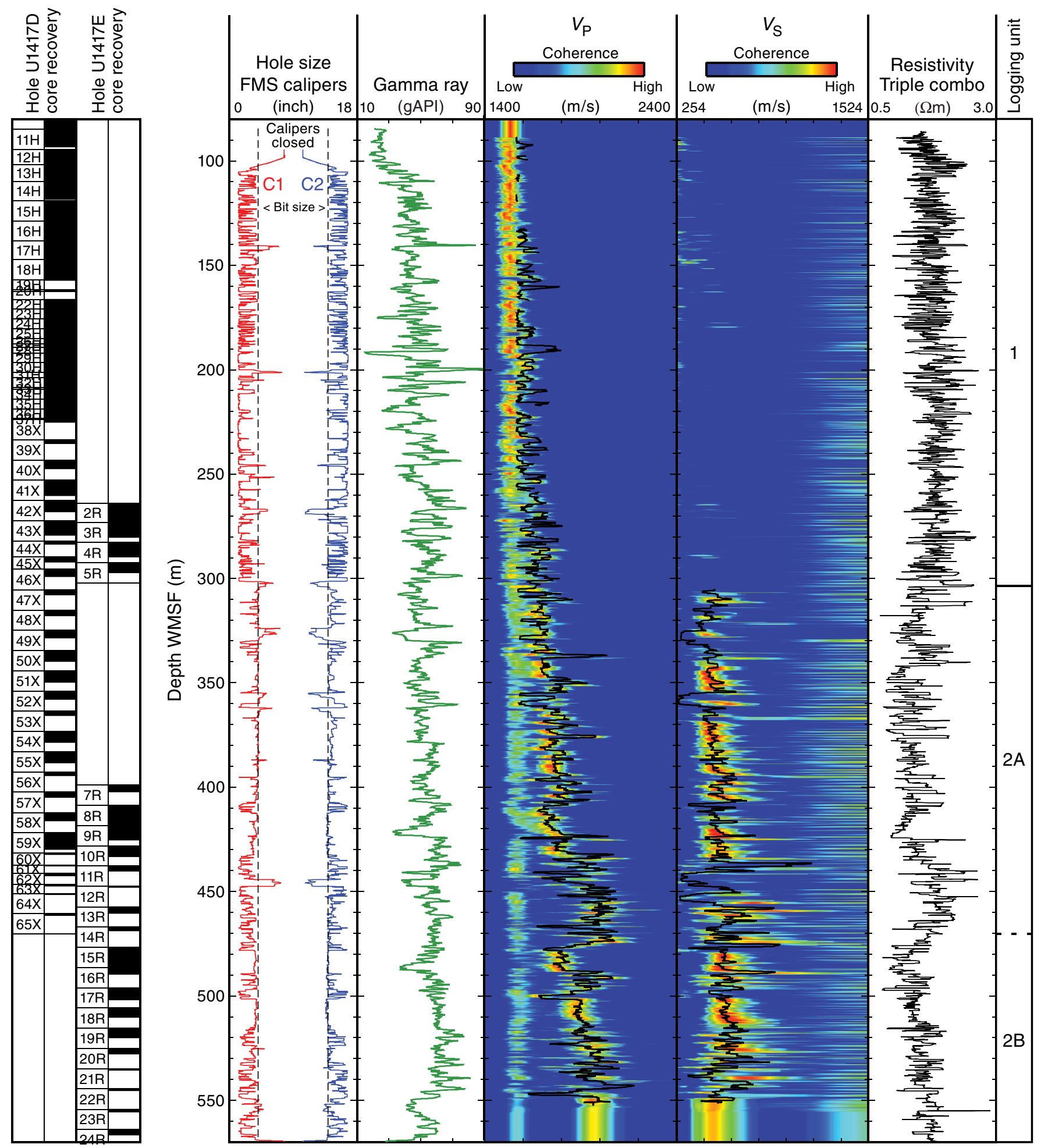


Figure F54. Summary of natural gamma ray logs, Hole U1417E. SGR = standard (total) gamma ray, CGR = computed gamma ray.

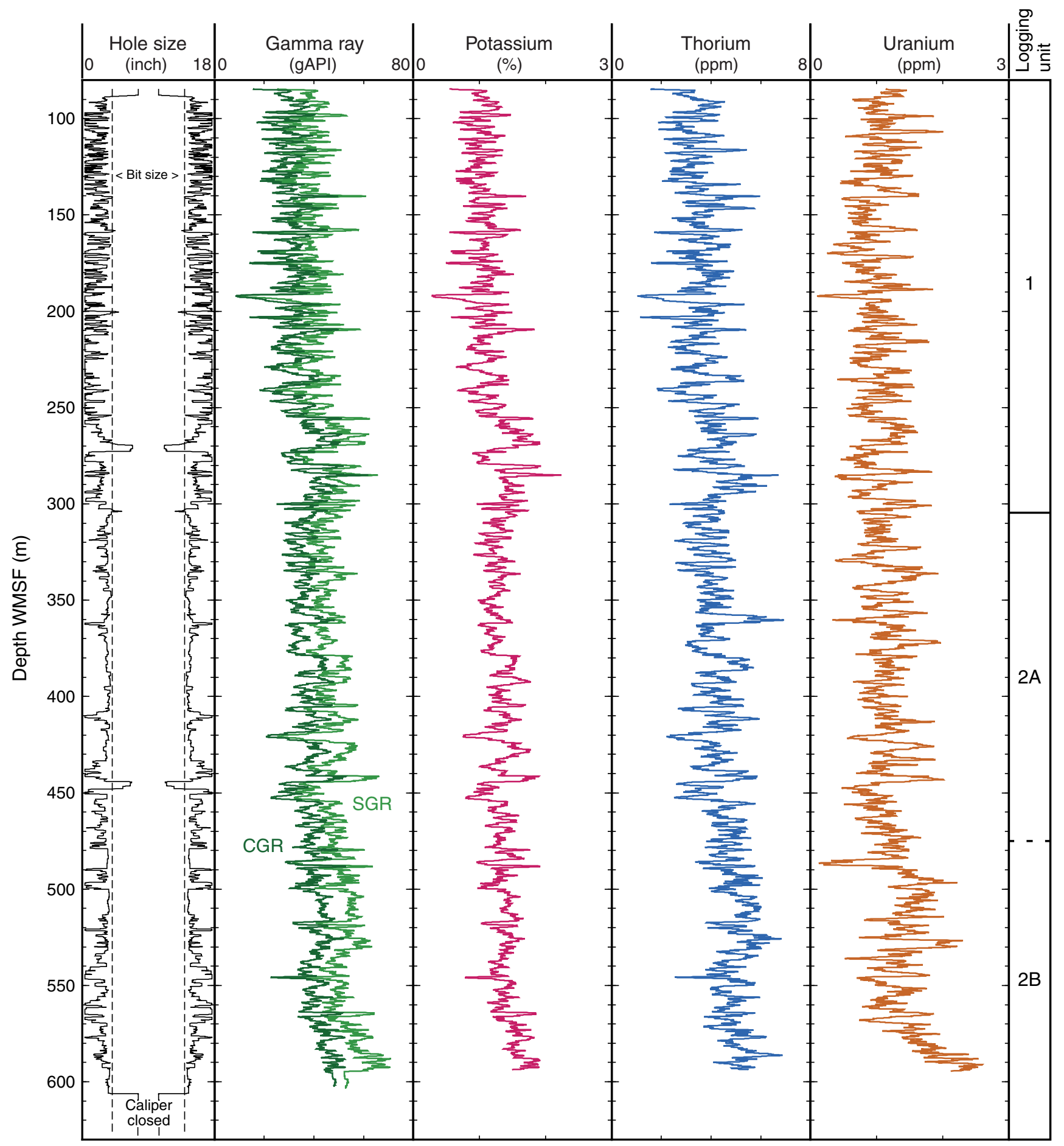


Figure F55. Summary of magnetic susceptibility logs recorded by the triple combo (TC) and Magnetic Susceptibility Sonde (MSS) tool string, Hole U1417E. Temperature-corrected (T-corrected) magnetic susceptibility shown for logging passes where tool temperature is linear. High-resolution magnetic susceptibility shows similar trends to natural gamma radiation (HSGR = total gamma radiation). Downlog = measurement made while tool is run from seafloor to the bottom of the hole. Pass 2 for MSS tool string = second pass of tool string from the bottom of the hole to the seafloor (Fig. F51).
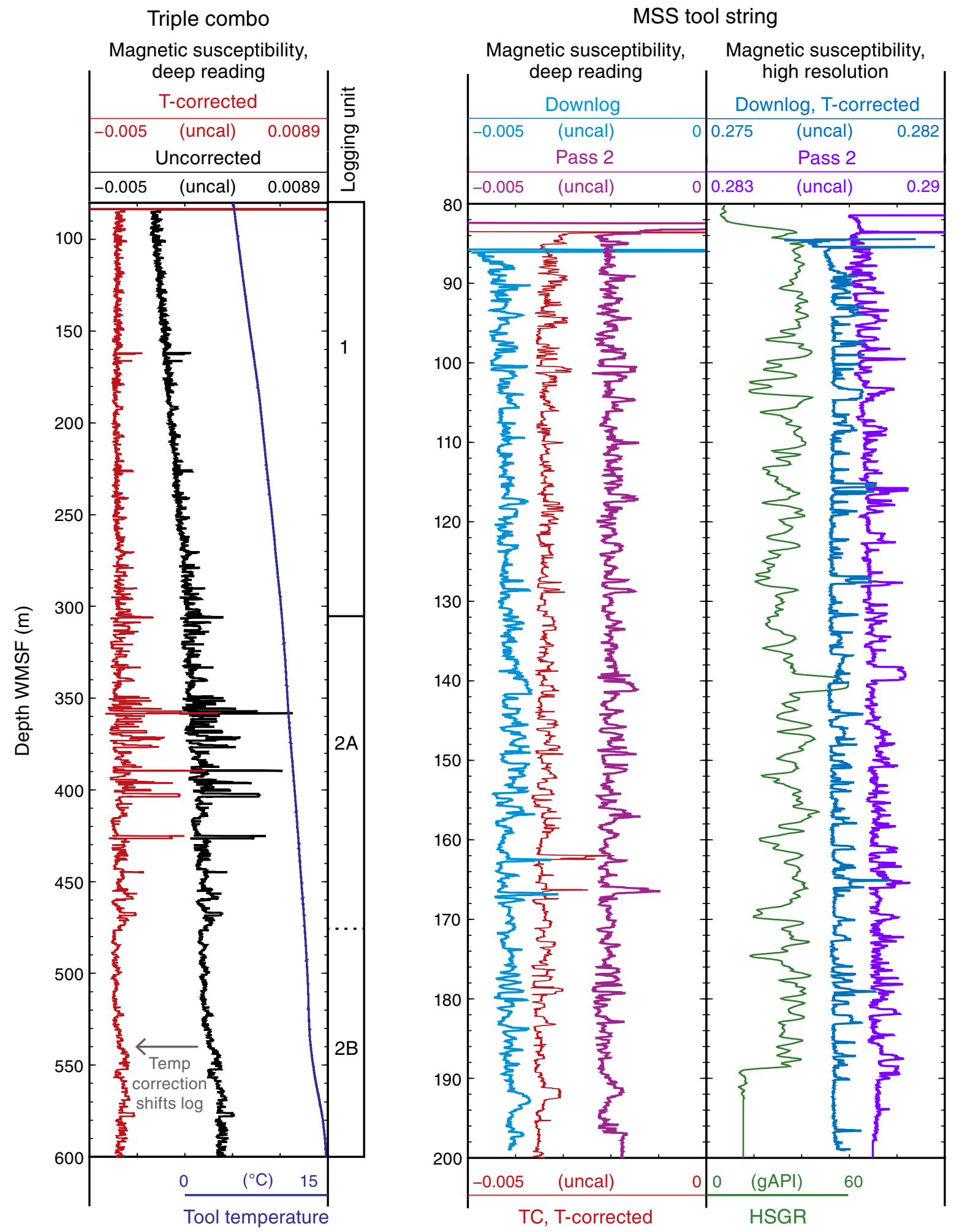
Figure F56. Examples of statically processed Formation MicroScanner (FMS) images from FMS-sonic Pass 1, Hole U1417E. Images show typical resistivity features and textures from (A) 95 to $102 \mathrm{~m}$ WSSF in logging Unit 1, (B) $~ 305$ to $312 \mathrm{~m}$ WSSF in logging Subunit 2A, and (C) $~ 510$ to $516 \mathrm{~m}$ WSSF in logging Subunit 2B. See "Downhole logging" in the "Methods" chapter (Jaeger et al., 2014) for explanation of WSSF depth scale.

A
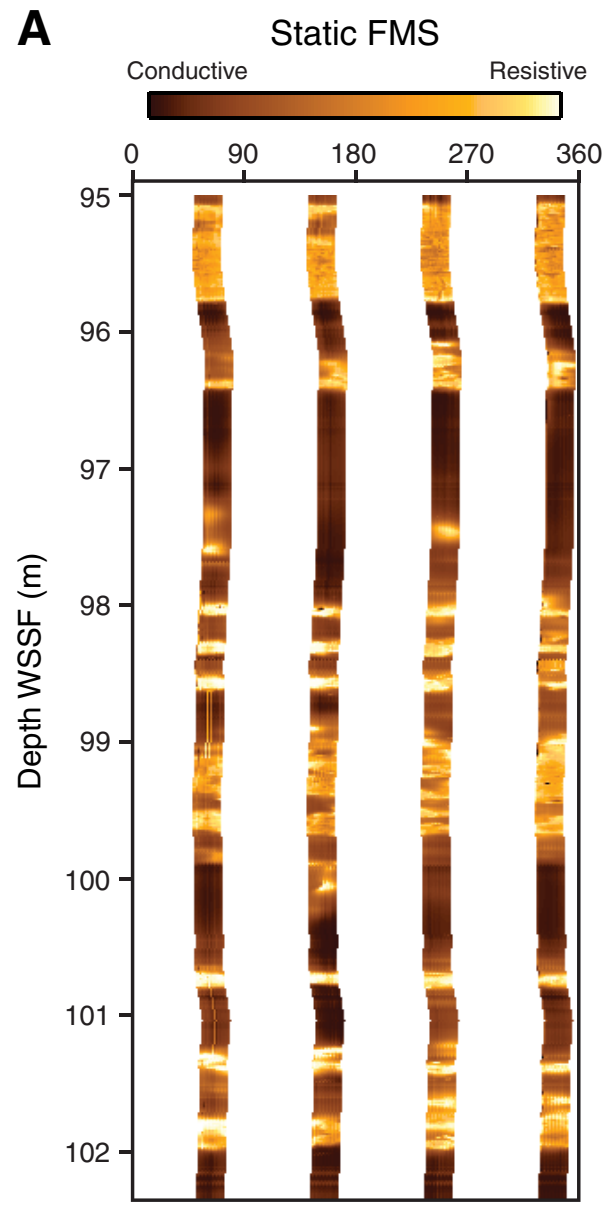

B
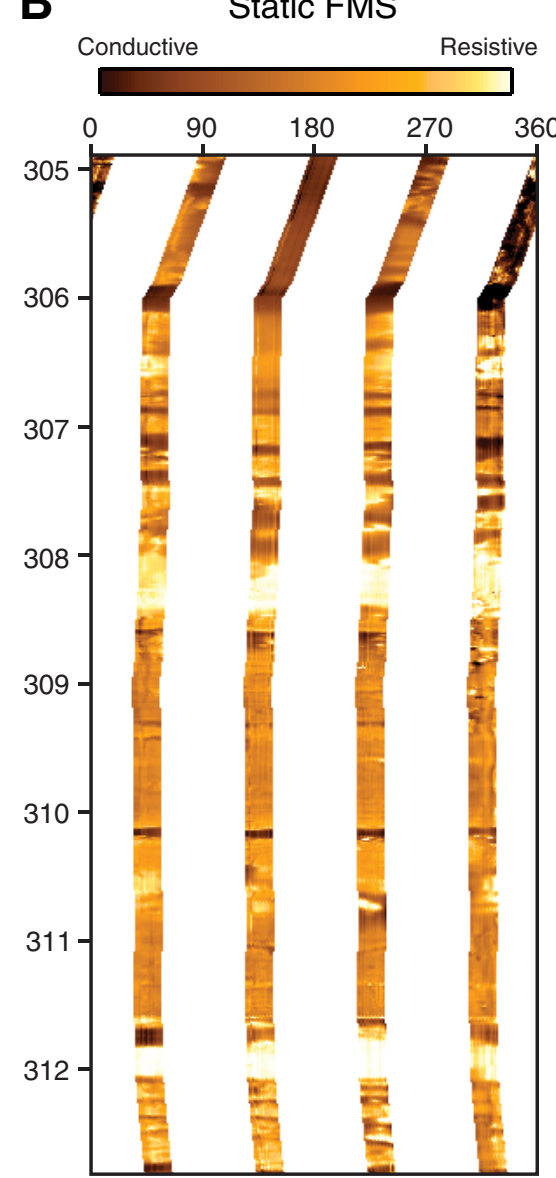

C

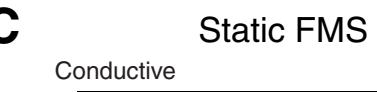

Resistive

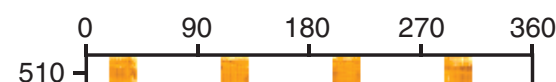

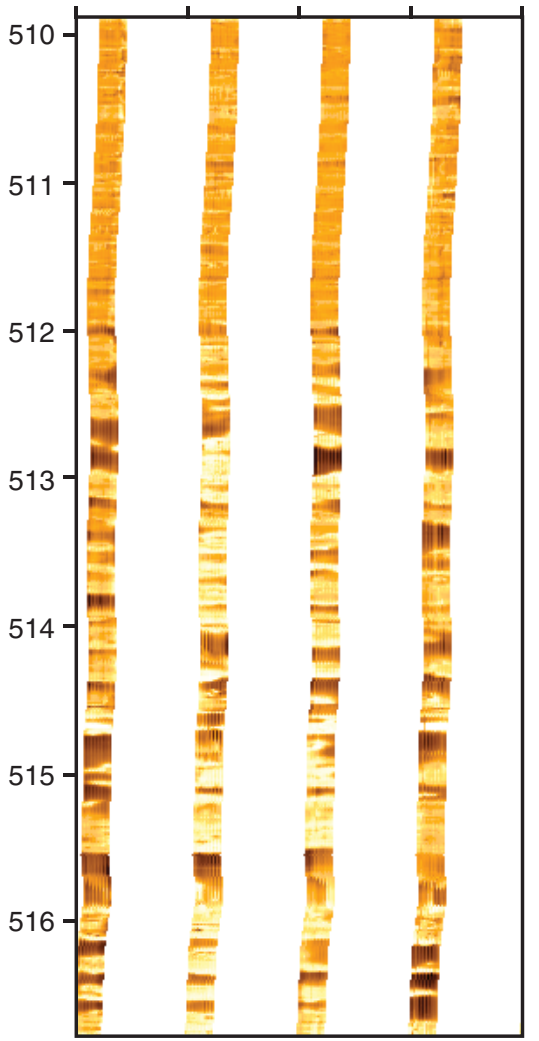


Figure F57. Vertical seismic profile waveforms and one-way arrival time picks (red stars) at two closely spaced stations, Hole U1417E.

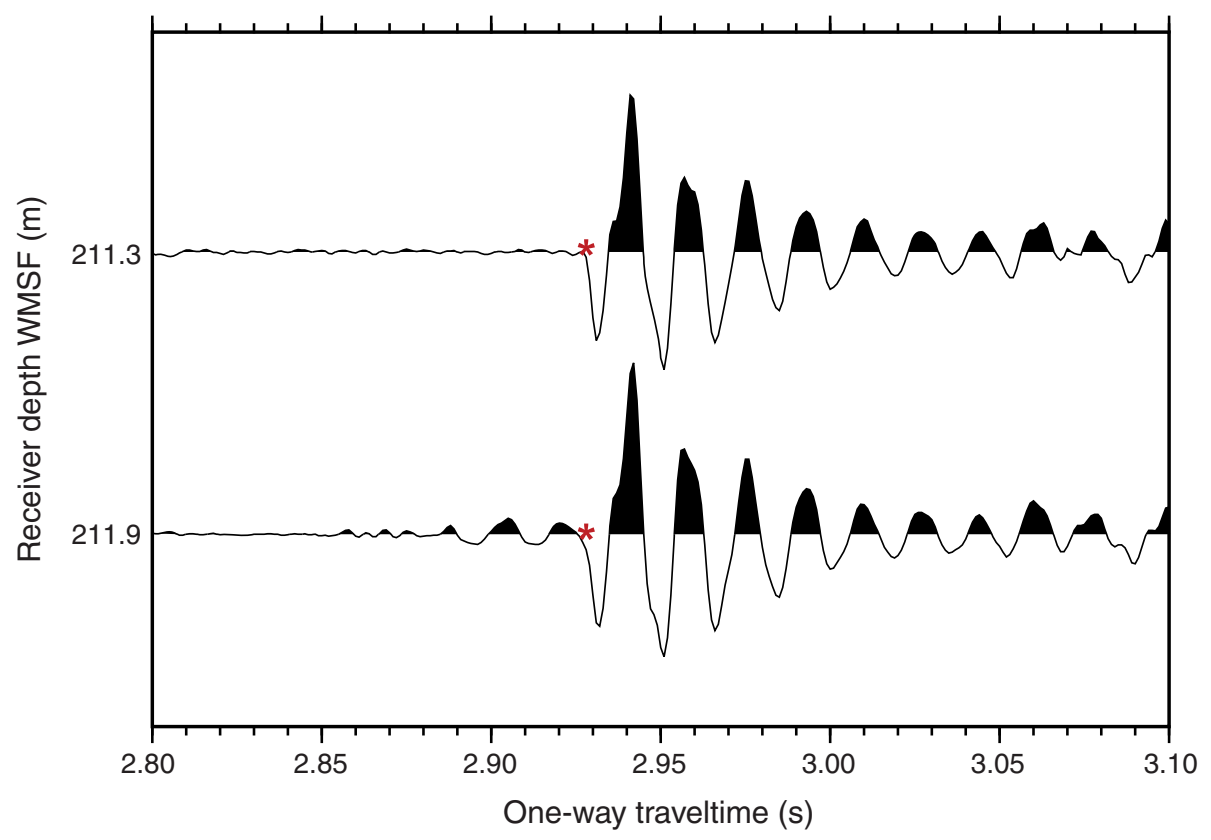


Figure F58. Comparison of core and logging magnetic susceptibility (MS), Site U1417. Diamict and sand are combined observations from Holes U1417A-U1417E, and logging data are from Hole U1417E. Green rectangle = interval of diamict interbedded with mud where MS is highest and most variable in logging data. Horizontal dashed lines = lithostratigraphic unit boundaries. Inset figure highlights correlation between diamict and high MS values in the core data. Red star = position of core image in overall stratigraphy. Overall, inset figure provides evidence for the diamict intervals causing high MS values in logging data. Up to $10 \mathrm{~m}$ difference may exist when comparing the CCSF-B and WMSF depth scales. WRMSL = Whole-Round Multisensor Logger.

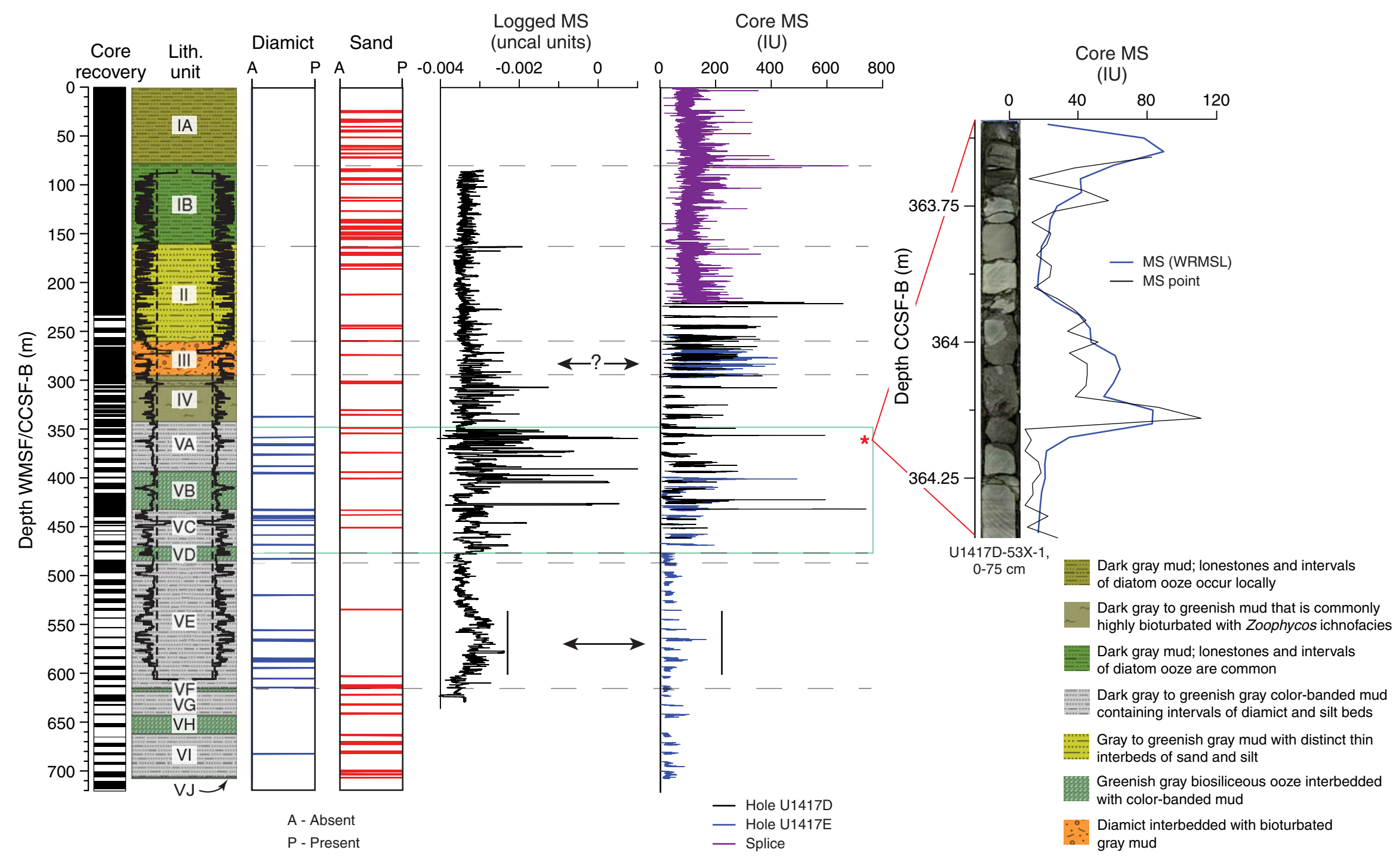


Figure F59. Comparison of core and logging natural gamma radiation, Site U1417. Sand, ash, and volcaniclastic sediment intervals are combined observations from Holes U1417A-U1417E. Green dashed line = correspondence between sand intervals and low gamma ray, gray dashed lines $=$ correspondences between ash and higher K counts. Up to $10 \mathrm{~m}$ difference may exist when comparing the CCSF-B and WMSF depth scales.

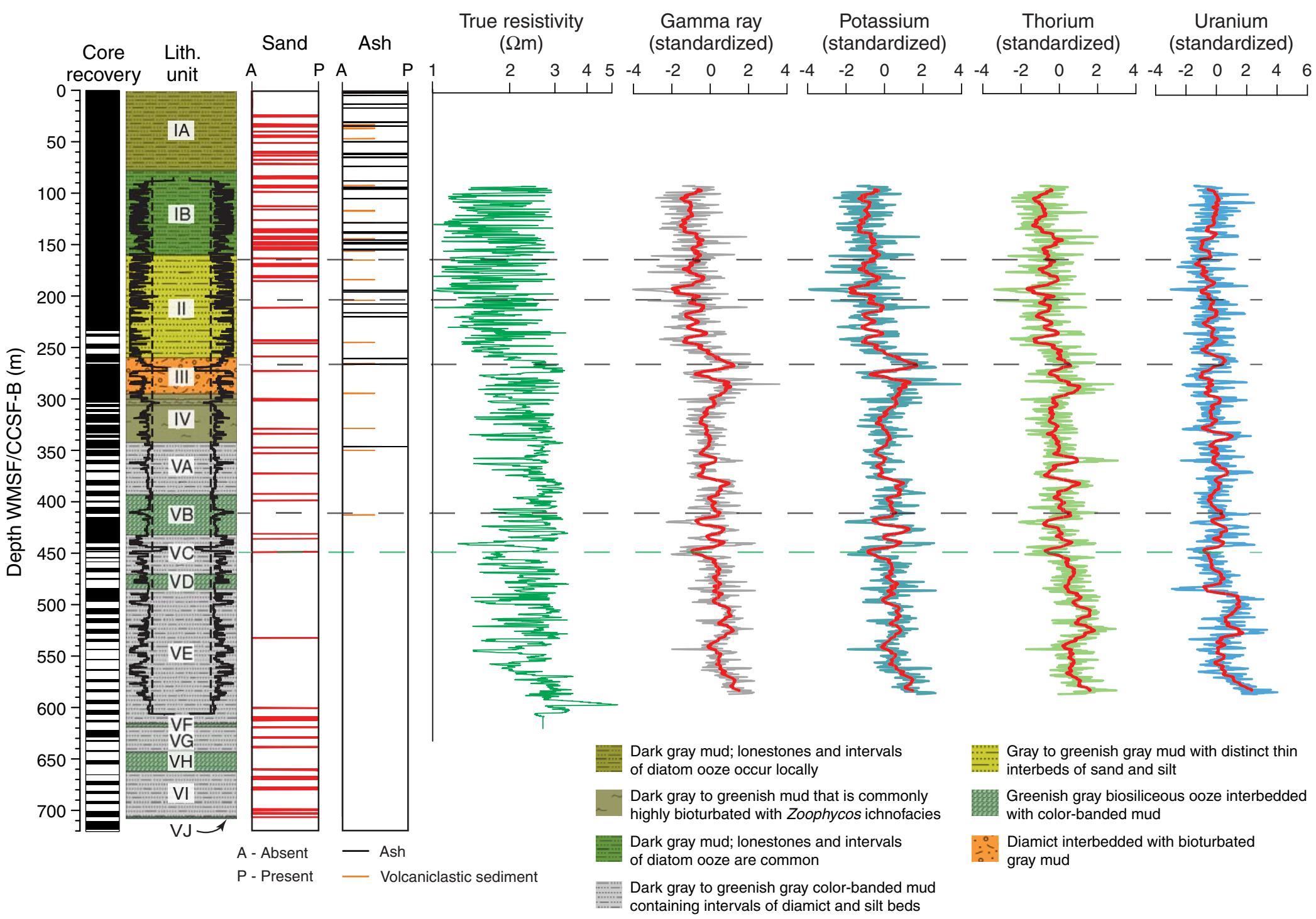


Figure F60. Comparison of core and logging physical properties, Site U1417. Downhole logging data are from Hole U1417E, within logging Unit 2 (see "Downhole logging"). Core natural gamma radiation (NGR) and magnetic susceptibility have been volume corrected (corr; see "Physical properties" 2014); magnetic susceptibility log has been temperature corrected (T-corr; see "Downhole logging"). MAD = moisture and density, GRA = gamma ray attenuation density. $P$-wave data: closed symbols $=$ automatic velocity picks, open symbols $=$ manual velocity picks. Dashed line $=$ logging subunit boundary. Up to a $10 \mathrm{~m}$ error exists when comparing the WMSF and CCSF depth scales.

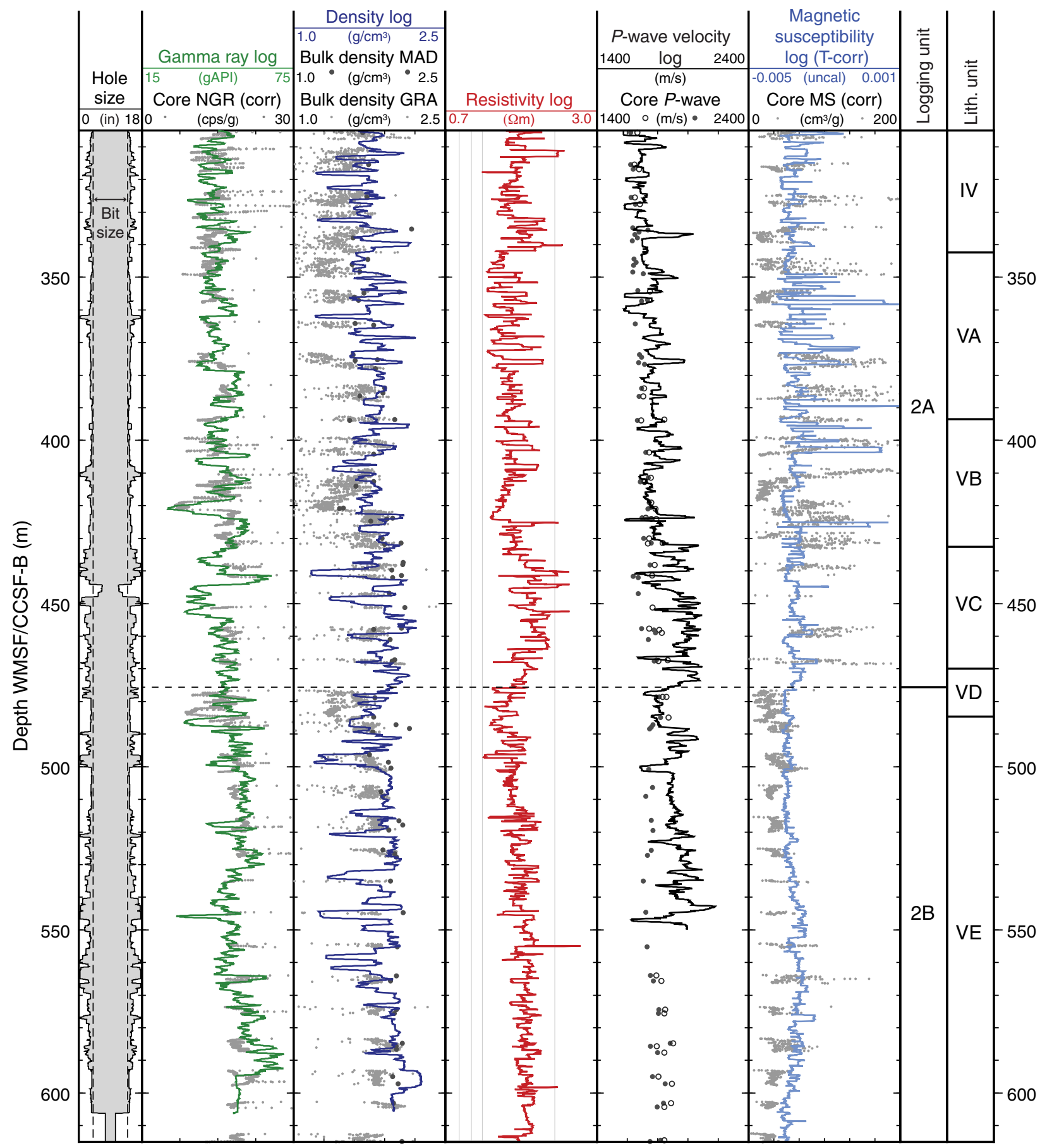


Figure F61. Seismic Line MGL1109MCS01 from 2011 USGS Law of the Sea survey aboard the R/V Marcus Langseth. Seismic Sequences I-III are interpreted after Reece et al. (2011) and demarcated by yellow horizons. Subsections of Sequence I (A-C) are demarcated by green horizons. Subsections of Sequence IA (1 and 2) are demarcated by a blue horizon. Subsections are interpreted based on dominant seismic character.

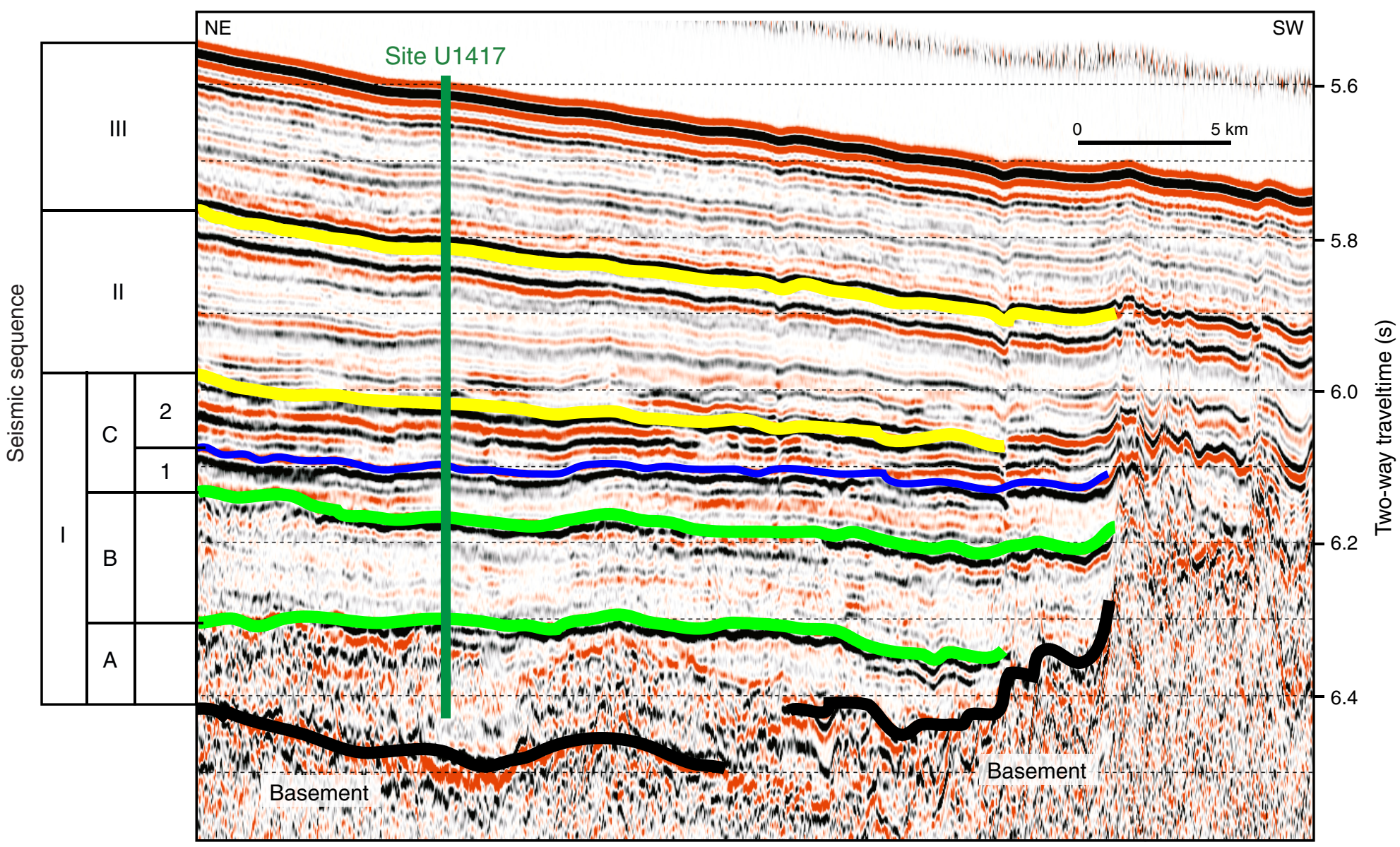


Figure F62. Seismic Line MGL1109MCS14 from 2011 USGS Law of the Sea survey aboard the R/V Marcus Langseth. Seismic Sequences I-III are interpreted after Reece et al. (2011) and demarcated by yellow horizons. Subsections of Sequence I (A-C) are demarcated by green horizons. Subsections of Sequence IC (IC1 and IC2) are demarcated by a blue horizon. Subsections are interpreted based on dominant seismic character.

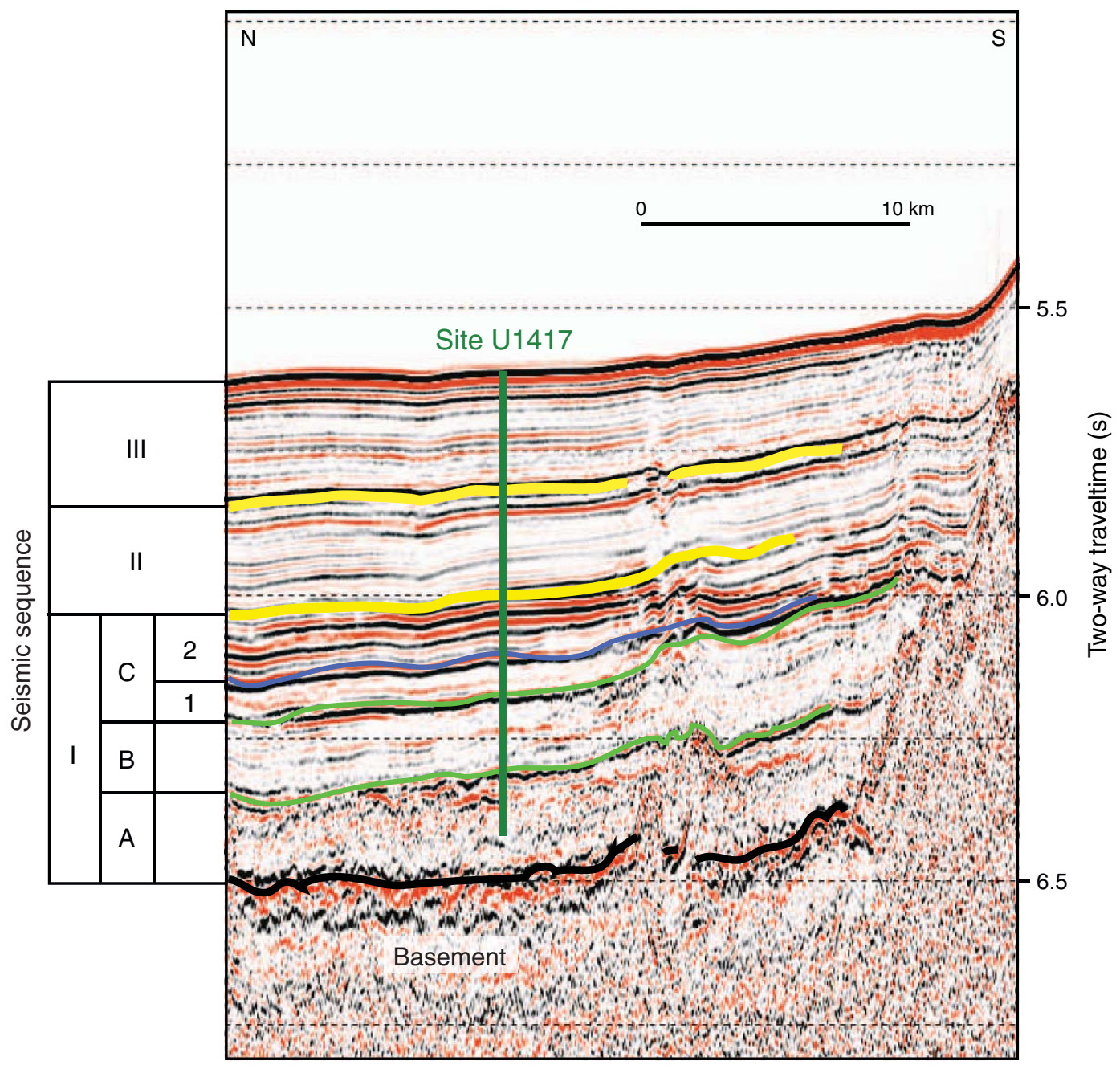


Table T1. Coring summary, Site U1417. (Continued on next four pages.)

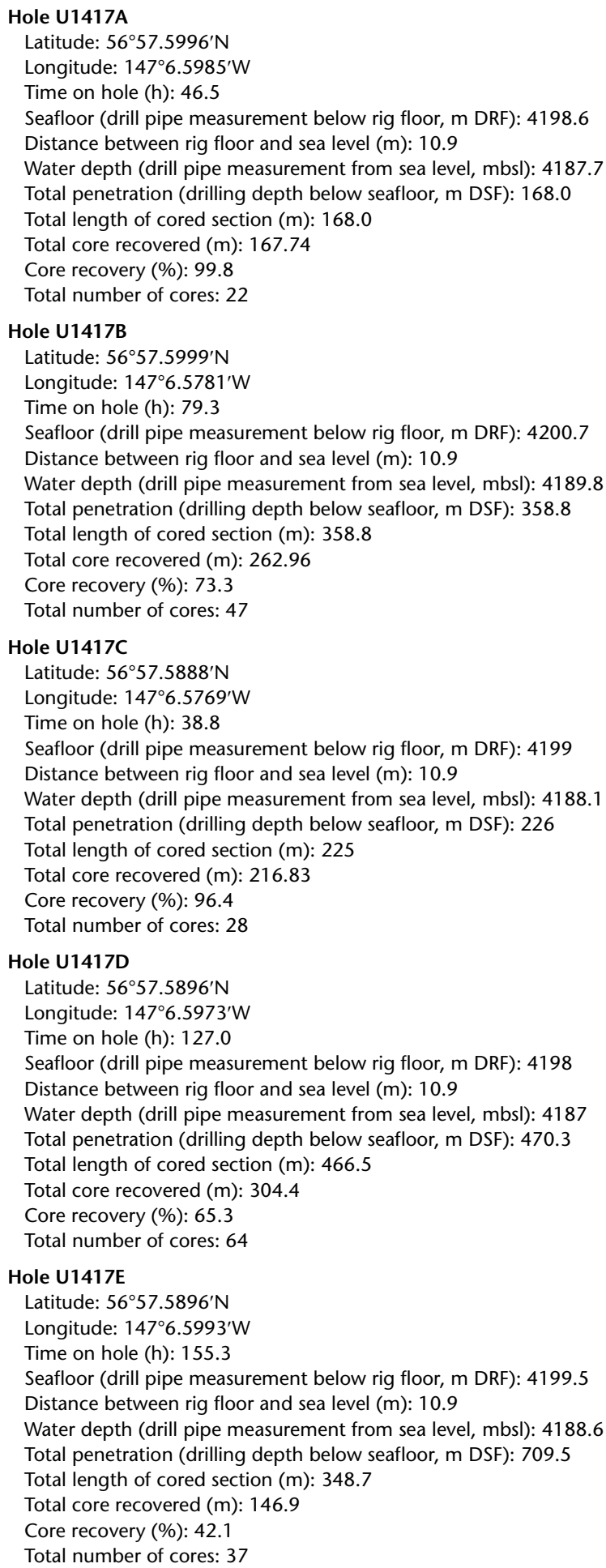

\begin{tabular}{|c|c|c|c|c|c|c|c|c|c|c|c|}
\hline \multirow[b]{2}{*}{ Core } & \multirow[b]{2}{*}{$\begin{array}{l}\text { Date } \\
(2013)\end{array}$} & \multirow[b]{2}{*}{$\begin{array}{l}\text { UTC time } \\
\text { (h) }\end{array}$} & \multicolumn{2}{|c|}{ Depth DSF (m) } & \multirow[b]{2}{*}{$\begin{array}{c}\text { Interval } \\
\text { advanced } \\
(\mathrm{m})\end{array}$} & \multicolumn{2}{|c|}{ Depth CSF (m) } & \multirow[b]{2}{*}{$\begin{array}{l}\text { Length } \\
\text { of core } \\
\text { recovered } \\
(\mathrm{m})\end{array}$} & \multirow[b]{2}{*}{$\begin{array}{c}\text { Recovery } \\
(\%)\end{array}$} & \multirow[b]{2}{*}{$\begin{array}{l}\text { Sections } \\
(N)\end{array}$} & \multirow[b]{2}{*}{$\begin{array}{c}\text { APC } \\
\text { system }\end{array}$} \\
\hline & & & $\begin{array}{c}\text { Top } \\
\text { of cored } \\
\text { interval }\end{array}$ & $\begin{array}{l}\text { Bottom } \\
\text { of cored } \\
\text { interval }\end{array}$ & & $\begin{array}{c}\text { Top } \\
\text { of cored } \\
\text { interval }\end{array}$ & $\begin{array}{l}\text { Bottom } \\
\text { of cored } \\
\text { interval }\end{array}$ & & & & \\
\hline \multicolumn{12}{|c|}{ 341-U1417A- } \\
\hline $1 \mathrm{H}$ & 5 Jun & 1140 & 0 & 5.4 & 5.4 & 0 & 5.48 & 5.48 & 101 & 5 & Full \\
\hline $2 \mathrm{H}$ & 5 Jun & 1310 & 5.4 & 14.9 & 9.5 & 5.4 & 15.37 & 9.97 & 105 & 8 & Full \\
\hline
\end{tabular}


Table T1 (continued). (Continued on next page.)

\begin{tabular}{|c|c|c|c|c|c|c|c|c|c|c|c|}
\hline \multirow[b]{2}{*}{ Core } & \multirow[b]{2}{*}{$\begin{array}{l}\text { Date } \\
(2013)\end{array}$} & \multirow[b]{2}{*}{$\begin{array}{l}\text { UTC time } \\
\text { (h) }\end{array}$} & \multicolumn{2}{|c|}{ Depth DSF (m) } & \multirow[b]{2}{*}{$\begin{array}{l}\text { Interval } \\
\text { advanced } \\
(\mathrm{m})\end{array}$} & \multicolumn{2}{|c|}{ Depth CSF (m) } & \multirow{2}{*}{$\begin{array}{l}\text { Length } \\
\text { of core } \\
\text { recovered } \\
\text { (m) }\end{array}$} & \multirow[b]{2}{*}{$\begin{array}{c}\text { Recovery } \\
\text { (\%) }\end{array}$} & \multirow[b]{2}{*}{$\begin{array}{l}\text { Sections } \\
(N)\end{array}$} & \\
\hline & & & $\begin{array}{c}\text { Top } \\
\text { of cored } \\
\text { interval }\end{array}$ & $\begin{array}{l}\text { Bottom } \\
\text { of cored } \\
\text { interval }\end{array}$ & & $\begin{array}{c}\text { Top } \\
\text { of cored } \\
\text { interval }\end{array}$ & $\begin{array}{l}\text { Bottom } \\
\text { of cored } \\
\text { interval }\end{array}$ & & & & $\begin{array}{c}\text { APC } \\
\text { system }\end{array}$ \\
\hline $3 \mathrm{H}$ & 5 Jun & 1410 & 14.9 & 24.4 & 9.5 & 14.9 & 24.67 & 9.77 & 103 & 8 & Full \\
\hline $4 \mathrm{H}$ & 5 Jun & 1530 & 24.4 & 33.9 & 9.5 & 24.4 & 34.58 & 10.18 & 107 & 8 & Full \\
\hline $5 \mathrm{H}$ & 5 Jun & 1625 & 33.9 & 43.4 & 9.5 & 33.9 & 42.24 & 8.34 & 88 & 7 & Full \\
\hline $6 \mathrm{H}$ & 5 Jun & 1720 & 43.4 & 44.9 & 1.5 & 43.4 & 44.9 & 1.5 & 100 & 2 & Full \\
\hline $7 \mathrm{H}$ & 5 Jun & 1845 & 44.9 & 54.4 & 9.5 & 44.9 & 54.95 & 10.05 & 106 & 8 & Full \\
\hline $8 \mathrm{H}$ & 5 Jun & 1945 & 54.4 & 56.9 & 2.5 & 54.4 & 56.91 & 2.51 & 100 & 3 & Full \\
\hline $9 \mathrm{H}$ & 5 Jun & 2110 & 56.9 & 66.4 & 9.5 & 56.9 & 65.92 & 9.02 & 95 & 7 & Full \\
\hline $10 \mathrm{H}$ & 5 Jun & 2245 & 66.4 & 75.9 & 9.5 & 66.4 & 76.13 & 9.73 & 102 & 8 & Full \\
\hline $11 \mathrm{H}$ & 5 Jun & 2345 & 75.9 & 85.4 & 9.5 & 75.9 & 83.72 & 7.82 & 82 & 7 & Full \\
\hline $12 \mathrm{H}$ & 6 Jun & 0045 & 85.4 & 94.9 & 9.5 & 85.4 & 95.18 & 9.78 & 103 & 8 & Full \\
\hline $13 \mathrm{H}$ & 6 Jun & 0210 & 94.9 & 104.4 & 9.5 & 94.9 & 104.4 & 9.5 & 100 & 8 & Full \\
\hline $14 \mathrm{H}$ & 6 Jun & 0305 & 104.4 & 113.9 & 9.5 & 104.4 & 113.95 & 9.55 & 101 & 8 & Full \\
\hline $15 \mathrm{H}$ & 6 Jun & 0400 & 113.9 & 123.4 & 9.5 & 113.9 & 123.49 & 9.59 & 101 & 8 & Full \\
\hline $16 \mathrm{H}$ & 6 Jun & 0500 & 123.4 & 132.9 & 9.5 & 123.4 & 133.16 & 9.76 & 103 & 8 & Full \\
\hline $17 \mathrm{H}$ & 6 Jun & 0600 & 132.9 & 142.4 & 9.5 & 132.9 & 142.3 & 9.4 & 99 & 7 & Full \\
\hline $18 \mathrm{H}$ & 6 Jun & 0715 & 142.4 & 149.4 & 7 & 142.4 & 149.42 & 7.02 & 100 & 7 & Full \\
\hline $19 \mathrm{H}$ & 6 Jun & 1120 & 149.4 & 157.3 & 7.9 & 149.4 & 157.37 & 7.97 & 101 & 7 & Full \\
\hline $20 \mathrm{H}$ & 6 Jun & 1245 & 157.3 & 158.4 & 1.1 & 157.3 & 158.45 & 1.15 & 105 & 2 & Full \\
\hline $21 \mathrm{H}$ & 6 Jun & 1410 & 158.4 & 163.2 & 4.8 & 158.4 & 163.25 & 4.85 & 101 & 4 & Half \\
\hline $22 \mathrm{H}$ & 6 Jun & 1530 & 163.2 & 168 & 4.8 & 163.2 & 168 & 4.8 & 100 & 4 & Half \\
\hline 341-U14 & & & & & & & & & & & \\
\hline $1 \mathrm{H}$ & 6 Jun & 2050 & 0 & 5.3 & 5.3 & 0 & 5.33 & 5.33 & 101 & 5 & Full \\
\hline $2 \mathrm{H}$ & 6 Jun & 2210 & 5.3 & 11.8 & 6.5 & 5.3 & 14.78 & 9.48 & 146 & 8 & Full \\
\hline $3 \mathrm{H}$ & 6 Jun & 2330 & 11.8 & 21.3 & 9.5 & 11.8 & 21.47 & 9.67 & 102 & 8 & Full \\
\hline $4 \mathrm{H}$ & 7 Jun & 0325 & 21.3 & 30.8 & 9.5 & 21.3 & 31.12 & 9.82 & 103 & 8 & Full \\
\hline $5 \mathrm{H}$ & 7 Jun & 0525 & 30.8 & 40.3 & 9.5 & 30.8 & 40.73 & 9.93 & 105 & 8 & Full \\
\hline $6 \mathrm{H}$ & 7 Jun & 0650 & 40.3 & 49.8 & 9.5 & 40.3 & 49.04 & 8.74 & 92 & 7 & Full \\
\hline $7 \mathrm{H}$ & 7 Jun & 0805 & 49.8 & 58 & 8.2 & 49.8 & 58.07 & 8.27 & 101 & 7 & Full \\
\hline $8 \mathrm{H}$ & 7 Jun & 1030 & 58 & 67.1 & 9.1 & 58 & 67.08 & 9.08 & 100 & 7 & Full \\
\hline $9 \mathrm{H}$ & 7 Jun & 1150 & 67.1 & 76.6 & 9.5 & 67.1 & 76.3 & 9.2 & 97 & 7 & Full \\
\hline $10 \mathrm{H}$ & 7 Jun & 1250 & 76.6 & 86.1 & 9.5 & 76.6 & 86.21 & 9.61 & 101 & 8 & Full \\
\hline $11 \mathrm{H}$ & 7 Jun & 1350 & 86.1 & 95.6 & 9.5 & 86.1 & 94.95 & 8.85 & 93 & 7 & Full \\
\hline $12 \mathrm{H}$ & 7 Jun & 1450 & 95.6 & 105.1 & 9.5 & 95.6 & 103.8 & 8.2 & 86 & 7 & Full \\
\hline $13 \mathrm{H}$ & 7 Jun & 1550 & 105.1 & 114.6 & 9.5 & 105.1 & 112.9 & 7.8 & 82 & 7 & Full \\
\hline $14 \mathrm{H}$ & 7 Jun & 1650 & 114.6 & 124.1 & 9.5 & 114.6 & 123.55 & 8.95 & 94 & 8 & Full \\
\hline $15 \mathrm{H}$ & 7 Jun & 1745 & 124.1 & 133.6 & 9.5 & 124.1 & 124.1 & 0 & 0 & 0 & Full \\
\hline $16 \mathrm{H}$ & 7 Jun & 1855 & 133.6 & 143.1 & 9.5 & 133.6 & 142.56 & 8.96 & 94 & 7 & Full \\
\hline $17 \mathrm{H}$ & 7 Jun & 1940 & 143.1 & 152.6 & 9.5 & 143.1 & 151.87 & 8.77 & 92 & 8 & Full \\
\hline $18 \mathrm{H}$ & 7 Jun & 2055 & 152.6 & 161.2 & 8.6 & 152.6 & 161.29 & 8.69 & 101 & 7 & Full \\
\hline $19 \mathrm{H}$ & 7 Jun & 2235 & 161.2 & 168 & 6.8 & 161.2 & 168.01 & 6.81 & 100 & 6 & Full \\
\hline $2 \mathrm{OH}$ & 8 Jun & 0010 & 168 & 176.3 & 8.3 & 168 & 176.36 & 8.36 & 101 & 8 & Full \\
\hline $21 \mathrm{H}$ & 8 Jun & 0245 & 176.3 & 178.1 & 1.8 & 176.3 & 178.19 & 1.89 & 105 & 2 & Half \\
\hline $22 \mathrm{H}$ & 8 Jun & 0350 & 178.1 & 182.8 & 4.7 & 178.1 & 183.07 & 4.97 & 106 & 5 & Half \\
\hline $23 \mathrm{H}$ & 8 Jun & 0455 & 182.8 & 187.5 & 4.7 & 182.8 & 187.73 & 4.93 & 105 & 5 & Half \\
\hline $24 \mathrm{H}$ & 8 Jun & 0555 & 187.5 & 192.2 & 4.7 & 187.5 & 192.25 & 4.75 & 101 & 5 & Half \\
\hline $25 \mathrm{H}$ & 8 Jun & 0650 & 192.2 & 196.9 & 4.7 & 192.2 & 196.32 & 4.12 & 88 & 4 & Half \\
\hline $26 \mathrm{H}$ & 8 Jun & 0750 & 196.9 & 197.5 & 0.6 & 196.9 & 197.57 & 0.67 & 112 & 2 & Half \\
\hline $27 \mathrm{H}$ & 8 Jun & 0905 & 197.5 & 202.2 & 4.7 & 197.5 & 202.56 & 5.06 & 108 & 5 & Half \\
\hline $28 \mathrm{H}$ & 8 Jun & 1015 & 202.2 & 206.9 & 4.7 & 202.2 & 207.31 & 5.11 & 109 & 5 & Half \\
\hline $29 \mathrm{H}$ & 8 Jun & 1115 & 206.9 & 211.6 & 4.7 & 206.9 & 211.8 & 4.9 & 104 & 5 & Half \\
\hline $30 \mathrm{H}$ & 8 Jun & 1220 & 211.6 & 216.3 & 4.7 & 211.6 & 215.46 & 3.86 & 82 & 4 & Half \\
\hline $31 \mathrm{H}$ & 8 Jun & 1310 & 216.3 & 221 & 4.7 & 216.3 & 221.03 & 4.73 & 101 & 4 & Half \\
\hline $32 \mathrm{H}$ & 8 Jun & 1410 & 221 & 222.2 & 1.2 & 221 & 222.21 & 1.21 & 101 & 2 & Half \\
\hline $33 \mathrm{H}$ & 8 Jun & 1515 & 222.2 & 223.4 & 1.2 & 222.2 & 223.45 & 1.25 & 104 & 2 & Half \\
\hline $34 X$ & 8 Jun & 1725 & 223.4 & 233 & 9.6 & 223.4 & 230.8 & 7.4 & 77 & 6 & \\
\hline $35 x$ & 8 Jun & 1850 & 233 & 242.6 & 9.6 & 233 & 235.88 & 2.88 & 30 & 3 & \\
\hline $36 x$ & 8 Jun & 2025 & 242.6 & 252.2 & 9.6 & 242.6 & 244.74 & 2.14 & 22 & 3 & \\
\hline $37 X$ & 8 Jun & 2245 & 252.2 & 261.8 & 9.6 & 252.2 & 256.19 & 3.99 & 42 & 4 & \\
\hline $38 \mathrm{X}$ & 9 Jun & 0125 & 261.8 & 271.5 & 9.7 & 261.8 & 265.8 & 4 & 41 & 4 & \\
\hline $39 x$ & 9 Jun & 0355 & 271.5 & 281.2 & 9.7 & 271.5 & 276.32 & 4.82 & 50 & 4 & \\
\hline $40 x$ & 9 Jun & 0555 & 281.2 & 290.9 & 9.7 & 281.2 & 285.56 & 4.36 & 45 & 4 & \\
\hline $41 x$ & 9 Jun & 0755 & 290.9 & 300.6 & 9.7 & 290.9 & 293.82 & 2.92 & 30 & 3 & \\
\hline $42 x$ & 9 Jun & 1015 & 300.6 & 310.3 & 9.7 & 300.6 & 303.11 & 2.51 & 26 & 3 & \\
\hline $43 x$ & 9 Jun & 1210 & 310.3 & 320 & 9.7 & 310.3 & 315.19 & 4.89 & 50 & 4 & \\
\hline $44 X$ & 9 Jun & 1400 & 320 & 329.7 & 9.7 & 320 & 324.07 & 4.07 & 42 & 4 & \\
\hline $45 x$ & 9 Jun & 1555 & 329.7 & 339.4 & 9.7 & 329.7 & 332.17 & 2.47 & 25 & 3 & \\
\hline $46 \mathrm{X}$ & 9 Jun & 1750 & 339.4 & 349.1 & 9.7 & 339.4 & 342.83 & 3.43 & 35 & 3 & \\
\hline
\end{tabular}


Table T1 (continued). (Continued on next page.)

\begin{tabular}{|c|c|c|c|c|c|c|c|c|c|c|c|}
\hline \multirow[b]{2}{*}{ Core } & \multirow[b]{2}{*}{$\begin{array}{l}\text { Date } \\
(2013)\end{array}$} & \multirow[b]{2}{*}{$\begin{array}{l}\text { UTC time } \\
\text { (h) }\end{array}$} & \multicolumn{2}{|c|}{ Depth DSF (m) } & \multirow[b]{2}{*}{$\begin{array}{l}\text { Interval } \\
\text { advanced } \\
(\mathrm{m})\end{array}$} & \multicolumn{2}{|c|}{ Depth CSF (m) } & \multirow{2}{*}{$\begin{array}{l}\text { Length } \\
\text { of core } \\
\text { recovered } \\
\text { (m) }\end{array}$} & \multirow[b]{2}{*}{$\begin{array}{l}\text { Recovery } \\
\text { (\%) }\end{array}$} & \multirow[b]{2}{*}{$\begin{array}{l}\text { Sections } \\
(N)\end{array}$} & \\
\hline & & & $\begin{array}{c}\text { Top } \\
\text { of cored } \\
\text { interval }\end{array}$ & $\begin{array}{l}\text { Bottom } \\
\text { of cored } \\
\text { interval }\end{array}$ & & $\begin{array}{c}\text { Top } \\
\text { of cored } \\
\text { interval }\end{array}$ & $\begin{array}{l}\text { Bottom } \\
\text { of cored } \\
\text { interval }\end{array}$ & & & & $\begin{array}{c}\text { APC } \\
\text { system }\end{array}$ \\
\hline $47 x$ & 9 Jun & 1935 & 349.1 & 358.8 & 9.7 & 349.1 & 350.21 & 1.11 & 11 & 2 & \\
\hline 341-U14 & & & & & & & & & & & \\
\hline 11 & 10 Jun & & & & $\star * * * *$ Drille & $\mathrm{d}$ interval $\mathrm{fr}$ & $\mathrm{m} 0$ to $1 \mathrm{n}$ & DSF ${ }^{* \star * * *}$ & & & \\
\hline $2 \mathrm{H}$ & 10 Jun & 0415 & 1 & 10.5 & 9.5 & 1 & 10.61 & 9.61 & 101 & 8 & Full \\
\hline $3 \mathrm{H}$ & 10 Jun & 0525 & 10.5 & 20 & 9.5 & 10.5 & 20.32 & 9.82 & 103 & 8 & Full \\
\hline $4 \mathrm{H}$ & 10 Jun & 0625 & 20 & 29.5 & 9.5 & 20 & 27.17 & 7.17 & 75 & 6 & Full \\
\hline $5 \mathrm{H}$ & 10 Jun & 0735 & 29.5 & 37 & 7.5 & 29.5 & 38.44 & 8.94 & 119 & 7 & Full \\
\hline $6 \mathrm{H}$ & 10 Jun & 0835 & 37 & 46.5 & 9.5 & 37 & 45.73 & 8.73 & 92 & 7 & Full \\
\hline $7 \mathrm{H}$ & 10 Jun & 0950 & 46.5 & 56 & 9.5 & 46.5 & 56.18 & 9.68 & 102 & 8 & Full \\
\hline $8 \mathrm{H}$ & 10 Jun & 1100 & 56 & 65.5 & 9.5 & 56 & 65.43 & 9.43 & 99 & 8 & Full \\
\hline $9 \mathrm{H}$ & 10 Jun & 1200 & 65.5 & 75 & 9.5 & 65.5 & 75.13 & 9.63 & 101 & 7 & Full \\
\hline $10 \mathrm{H}$ & 10 Jun & 1300 & 75 & 84.5 & 9.5 & 75 & 84.9 & 9.9 & 104 & 8 & Full \\
\hline $11 \mathrm{H}$ & 10 Jun & 1420 & 84.5 & 94 & 9.5 & 84.5 & 94.07 & 9.57 & 101 & 8 & Full \\
\hline $12 \mathrm{H}$ & 10 Jun & 1520 & 94 & 103.5 & 9.5 & 94 & 103.27 & 9.27 & 98 & 8 & Full \\
\hline $13 \mathrm{H}$ & 10 Jun & 1625 & 103.5 & 113 & 9.5 & 103.5 & 103.55 & 0.05 & 1 & 1 & Full \\
\hline $14 \mathrm{H}$ & 10 Jun & 1730 & 113 & 122.5 & 9.5 & 113 & 122.66 & 9.66 & 102 & 8 & Full \\
\hline $15 \mathrm{H}$ & 10 Jun & 1855 & 122.5 & 132 & 9.5 & 122.5 & 132.32 & 9.82 & 103 & 8 & Full \\
\hline $16 \mathrm{H}$ & 10 Jun & 2025 & 132 & 141.5 & 9.5 & 132 & 141.59 & 9.59 & 101 & 7 & Full \\
\hline $17 \mathrm{H}$ & 10 Jun & 2130 & 141.5 & 151 & 9.5 & 141.5 & 151.26 & 9.76 & 103 & 8 & Full \\
\hline $18 \mathrm{H}$ & 10 Jun & 2255 & 151 & 160.5 & 9.5 & 151 & 161.01 & 10.01 & 105 & 8 & Full \\
\hline $19 \mathrm{H}$ & 11 Jun & 0005 & 160.5 & 164.1 & 3.6 & 160.5 & 164.17 & 3.67 & 102 & 4 & Full \\
\hline $20 \mathrm{H}$ & 11 Jun & 0120 & 164.1 & 173.6 & 9.5 & 164.1 & 173.93 & 9.83 & 103 & 8 & Full \\
\hline $21 \mathrm{H}$ & 11 Jun & 0245 & 173.6 & 183.1 & 9.5 & 173.6 & 183.29 & 9.69 & 102 & 8 & Full \\
\hline $22 \mathrm{H}$ & 11 Jun & 0355 & 183.1 & 192.6 & 9.5 & 183.1 & 192.6 & 9.5 & 100 & 8 & Full \\
\hline $23 \mathrm{H}$ & 11 Jun & 0500 & 192.6 & 197 & 4.4 & 192.6 & 197.06 & 4.46 & 101 & 4 & Full \\
\hline $24 \mathrm{H}$ & 11 Jun & 0610 & 197 & 206.2 & 9.2 & 197 & 206.23 & 9.23 & 100 & 7 & Full \\
\hline $25 \mathrm{H}$ & 11 Jun & 0735 & 206.2 & 213.8 & 7.6 & 206.2 & 213.8 & 7.6 & 100 & 7 & Full \\
\hline $26 \mathrm{H}$ & 11 Jun & 0930 & 213.8 & 218.5 & 4.7 & 213.8 & 218.43 & 4.63 & 99 & 4 & Half \\
\hline $27 \mathrm{H}$ & 11 Jun & 1110 & 218.5 & 222.2 & 3.7 & 218.5 & 222.23 & 3.73 & 101 & 3 & Half \\
\hline $28 \mathrm{H}$ & 11 Jun & 1220 & 222.2 & 223.9 & 1.7 & 222.2 & 223.95 & 1.75 & 103 & 3 & Half \\
\hline $29 \mathrm{H}$ & 11 Jun & 1330 & 223.9 & 226 & 2.1 & 223.9 & 226 & 2.1 & 100 & 3 & Half \\
\hline 341-U14 & & & & & & & & & & & \\
\hline $1 \mathrm{H}$ & 11 Jun & 2020 & 0 & 6 & 6 & 0 & 6.05 & 6.05 & 101 & 5 & Full \\
\hline $2 \mathrm{H}$ & 11 Jun & 2125 & 6 & 15.5 & 9.5 & 6 & 14.51 & 8.51 & 90 & 7 & Full \\
\hline $3 \mathrm{H}$ & 11 Jun & 2220 & 15.5 & 25 & 9.5 & 15.5 & 24.56 & 9.06 & 95 & 8 & Full \\
\hline $4 \mathrm{H}$ & 11 Jun & 2345 & 25 & 34.5 & 9.5 & 25 & 34.83 & 9.83 & 103 & 8 & Full \\
\hline $5 \mathrm{H}$ & 12 Jun & 0045 & 34.5 & 44 & 9.5 & 34.5 & 44.2 & 9.7 & 102 & 8 & Full \\
\hline $6 \mathrm{H}$ & 12 Jun & 0140 & 44 & 53.5 & 9.5 & 44 & 52.59 & 8.59 & 90 & 7 & Full \\
\hline $7 \mathrm{H}$ & 12 Jun & 0300 & 53.5 & 56.5 & 3 & 53.5 & 58.1 & 4.6 & 153 & 4 & Full \\
\hline $8 \mathrm{H}$ & 12 Jun & 0425 & 56.5 & 66 & 9.5 & 56.5 & 66.1 & 9.6 & 101 & 8 & Full \\
\hline $9 \mathrm{H}$ & 12 Jun & 0515 & 66 & 75.5 & 9.5 & 66 & 75.16 & 9.16 & 96 & 8 & Full \\
\hline $10 \mathrm{H}$ & 12 Jun & 0610 & 75.5 & 85 & 9.5 & 75.5 & 85.05 & 9.55 & 101 & 8 & Full \\
\hline $11 \mathrm{H}$ & 12 Jun & 0730 & 85 & 94.5 & 9.5 & 85 & 93.24 & 8.24 & 87 & 7 & Full \\
\hline $12 \mathrm{H}$ & 12 Jun & 0900 & 94.5 & 101.8 & 7.3 & 94.5 & 101.86 & 7.36 & 101 & 6 & Full \\
\hline $13 \mathrm{H}$ & 12 Jun & 1030 & 101.8 & 109.8 & 8 & 101.8 & 110.06 & 8.26 & 103 & 7 & Full \\
\hline $14 \mathrm{H}$ & 12 Jun & 1205 & 109.8 & 119.3 & 9.5 & 109.8 & 118.3 & 8.5 & 89 & 7 & Full \\
\hline $15 \mathrm{H}$ & 12 Jun & 1300 & 119.3 & 128.8 & 9.5 & 119.3 & 128.88 & 9.82 & 103 & 7 & Full \\
\hline $16 \mathrm{H}$ & 12 Jun & 1400 & 128.8 & 138.3 & 9.5 & 128.8 & 138.28 & 9.48 & 100 & 8 & Full \\
\hline $17 \mathrm{H}$ & 12 Jun & 1500 & 138.3 & 147.4 & 9.1 & 138.3 & 147.42 & 9.12 & 100 & 7 & Full \\
\hline $18 \mathrm{H}$ & 12 Jun & 1555 & 147.4 & 156.9 & 9.5 & 147.4 & 156.96 & 9.56 & 101 & 7 & Full \\
\hline $19 \mathrm{H}$ & 12 Jun & 1710 & 156.9 & 161.6 & 4.7 & 156.9 & 157.08 & 0.18 & 4 & 1 & Half \\
\hline $20 \mathrm{H}$ & 12 Jun & 1805 & 161.6 & 162.5 & 0.9 & 161.6 & 162.54 & 0.94 & 104 & 2 & Half \\
\hline 211 & 12 Jun & & & & ${ }^{\star *}$ Drilled int & erval from & 62.5 to 16 & $6.3 \mathrm{~m} \mathrm{DSF}^{*}$ & & & \\
\hline $22 \mathrm{H}$ & 12 Jun & 1930 & 166.3 & 171 & 4.7 & 166.3 & 170.66 & 4.36 & 93 & 4 & Half \\
\hline $23 \mathrm{H}$ & 12 Jun & 2035 & 171 & 175.7 & 4.7 & 171 & 176.01 & 5.01 & 107 & 5 & Half \\
\hline $24 \mathrm{H}$ & 12 Jun & 2125 & 175.7 & 180.4 & 4.7 & 175.7 & 180.45 & 4.75 & 101 & 4 & Half \\
\hline $25 \mathrm{H}$ & 12 Jun & 2220 & 180.4 & 185.1 & 4.7 & 180.4 & 185.38 & 4.98 & 106 & 5 & Half \\
\hline $26 \mathrm{H}$ & 12 Jun & 2315 & 185.1 & 187.5 & 2.4 & 185.1 & 187.54 & 2.44 & 102 & 3 & Half \\
\hline $27 \mathrm{H}$ & 13 Jun & 0025 & 187.5 & 189.3 & 1.8 & 187.5 & 189.32 & 1.82 & 101 & 3 & Half \\
\hline $28 \mathrm{H}$ & 13 Jun & 0140 & 189.3 & 192.1 & 2.8 & 189.3 & 192.15 & 2.85 & 102 & 3 & Half \\
\hline $29 \mathrm{H}$ & 13 Jun & 0255 & 192.1 & 196.5 & 4.4 & 192.1 & 196.59 & 4.49 & 102 & 4 & Half \\
\hline $30 \mathrm{H}$ & 13 Jun & 0520 & 196.5 & 201.2 & 4.7 & 196.5 & 201.29 & 4.79 & 102 & 4 & Half \\
\hline $31 \mathrm{H}$ & 13 Jun & 0730 & 201.2 & 203.9 & 2.7 & 201.2 & 203.9 & 2.7 & 100 & 3 & Half \\
\hline $32 \mathrm{H}$ & 13 Jun & 0850 & 203.9 & 208.6 & 4.7 & 203.9 & 208.92 & 5.02 & 107 & 5 & Half \\
\hline $33 \mathrm{H}$ & 13 Jun & 0950 & 208.6 & 209.4 & 0.8 & 208.6 & 209.42 & 0.82 & 102 & 2 & Half \\
\hline $34 \mathrm{H}$ & 13 Jun & 1125 & 209.4 & 214.1 & 4.7 & 209.4 & 214.07 & 4.67 & 99 & 4 & Half \\
\hline
\end{tabular}


Table T1 (continued). (Continued on next page.)

\begin{tabular}{|c|c|c|c|c|c|c|c|c|c|c|c|}
\hline \multirow[b]{2}{*}{ Core } & \multirow[b]{2}{*}{$\begin{array}{l}\text { Date } \\
\text { (2013) }\end{array}$} & \multirow[b]{2}{*}{$\begin{array}{l}\text { UTC time } \\
\text { (h) }\end{array}$} & \multicolumn{2}{|c|}{ Depth DSF (m) } & \multirow[b]{2}{*}{$\begin{array}{l}\text { Interval } \\
\text { advanced } \\
(\mathrm{m})\end{array}$} & \multicolumn{2}{|c|}{ Depth CSF (m) } & \multirow{2}{*}{$\begin{array}{l}\text { Length } \\
\text { of core } \\
\text { recovered } \\
\text { (m) }\end{array}$} & \multirow[b]{2}{*}{$\begin{array}{c}\text { Recovery } \\
\text { (\%) }\end{array}$} & \multirow[b]{2}{*}{$\begin{array}{l}\text { Sections } \\
(N)\end{array}$} & \multirow[b]{2}{*}{$\begin{array}{l}\text { APC } \\
\text { system }\end{array}$} \\
\hline & & & $\begin{array}{c}\text { Top } \\
\text { of cored } \\
\text { interval }\end{array}$ & $\begin{array}{l}\text { Bottom } \\
\text { of cored } \\
\text { interval }\end{array}$ & & $\begin{array}{c}\text { Top } \\
\text { of cored } \\
\text { interval }\end{array}$ & $\begin{array}{l}\text { Bottom } \\
\text { of cored } \\
\text { interval }\end{array}$ & & & & \\
\hline $35 \mathrm{H}$ & 13 Jun & 1255 & 214.1 & 218.8 & 4.7 & 214.1 & 218.77 & 4.67 & 99 & 4 & Half \\
\hline $36 \mathrm{H}$ & 13 Jun & 1430 & 218.8 & 223.3 & 4.5 & 218.8 & 223.37 & 4.57 & 102 & 4 & Half \\
\hline $37 \mathrm{H}$ & 13 Jun & 1540 & 223.3 & 223.9 & 0.6 & 223.3 & 223.89 & 0.59 & 98 & 2 & Half \\
\hline $38 x$ & 13 Jun & 1825 & 223.9 & 233.6 & 9.7 & 223.9 & 225.09 & 1.19 & 12 & 2 & \\
\hline $39 x$ & 13 Jun & 2015 & 233.6 & 243.3 & 9.7 & 233.6 & 235.37 & 1.77 & 18 & 2 & \\
\hline $40 x$ & 13 Jun & 2325 & 243.3 & 253 & 9.7 & 243.3 & 247.33 & 4.03 & 42 & 4 & \\
\hline $41 x$ & 14 Jun & 0135 & 253 & 262.7 & 9.7 & 253 & 260.21 & 7.21 & 74 & 6 & \\
\hline $42 x$ & 14 Jun & 0415 & 262.7 & 272.4 & 9.7 & 262.7 & 267.96 & 5.26 & 54 & 5 & \\
\hline $43 x$ & 14 Jun & 0645 & 272.4 & 282.1 & 9.7 & 272.4 & 279.19 & 6.79 & 70 & 6 & \\
\hline $44 X$ & 14 Jun & 0940 & 282.1 & 289.7 & 7.6 & 282.1 & 283.5 & 1.4 & 18 & 2 & \\
\hline $45 x$ & 14 Jun & 1140 & 289.7 & 295.7 & 6 & 289.7 & 292.2 & 2.5 & 42 & 3 & \\
\hline $46 x$ & 14 Jun & 1335 & 295.7 & 305.4 & 9.7 & 295.7 & 299.13 & 3.43 & 35 & 4 & \\
\hline $47 X$ & 14 Jun & 1600 & 305.4 & 315.1 & 9.7 & 305.4 & 307.86 & 2.46 & 25 & 4 & \\
\hline $48 x$ & 14 Jun & 1815 & 315.1 & 324.8 & 9.7 & 315.1 & 317.76 & 2.66 & 27 & 3 & \\
\hline $49 x$ & 14 Jun & 2005 & 324.8 & 334.5 & 9.7 & 324.8 & 328.44 & 3.64 & 38 & 4 & \\
\hline $50 x$ & 14 Jun & 2205 & 334.5 & 344.2 & 9.7 & 334.5 & 339.62 & 5.12 & 53 & 5 & \\
\hline $51 X$ & 14 Jun & 2350 & 344.2 & 353.9 & 9.7 & 344.2 & 349.66 & 5.46 & 56 & 5 & \\
\hline $52 X$ & 15 Jun & 0145 & 353.9 & 363.6 & 9.7 & 353.9 & 357.91 & 4.01 & 41 & 4 & \\
\hline $53 x$ & 15 Jun & 0330 & 363.6 & 373.3 & 9.7 & 363.6 & 365.6 & 2 & 21 & 3 & \\
\hline $54 X$ & 15 Jun & 0555 & 373.3 & 383 & 9.7 & 373.3 & 378.47 & 5.17 & 53 & 5 & \\
\hline $55 X$ & 15 Jun & 0815 & 383 & 392.7 & 9.7 & 383 & 388.19 & 5.19 & 54 & 5 & \\
\hline $56 \mathrm{X}$ & 15 Jun & 1100 & 392.7 & 402.4 & 9.7 & 392.7 & 394.46 & 1.76 & 18 & 2 & \\
\hline $57 X$ & 15 Jun & 1355 & 402.4 & 412.1 & 9.7 & 402.4 & 404.9 & 2.5 & 26 & 3 & \\
\hline $58 \mathrm{X}$ & 15 Jun & 1700 & 412.1 & 421.8 & 9.7 & 412.1 & 416.12 & 4.02 & 41 & 4 & \\
\hline $59 X$ & 15 Jun & 1920 & 421.8 & 431.5 & 9.7 & 421.8 & 429.7 & 7.9 & 81 & 7 & \\
\hline $60 x$ & 15 Jun & 2210 & 431.5 & 437.2 & 5.7 & 431.5 & 432.11 & 0.61 & 11 & 2 & \\
\hline $61 X$ & 16 Jun & 0045 & 437.2 & 441.2 & 4 & 437.2 & 437.7 & 0.5 & 12 & 2 & \\
\hline $62 x$ & 16 Jun & 0415 & 441.2 & 446.7 & 5.5 & 441.2 & 442.33 & 1.13 & 21 & 2 & \\
\hline $63 X$ & 16 Jun & 0615 & 446.7 & 450.9 & 4.2 & 446.7 & 447.33 & 0.63 & 15 & 2 & \\
\hline $64 X$ & 16 Jun & 0835 & 450.9 & 460.6 & 9.7 & 450.9 & 451.48 & 0.58 & 6 & 2 & \\
\hline $65 x$ & 16 Jun & 1100 & 460.6 & 470.3 & 9.7 & 460.6 & 461.46 & 0.86 & 9 & 2 & \\
\hline
\end{tabular}

341-U1417E-

\begin{tabular}{|c|c|c|c|c|c|c|c|c|c|c|}
\hline 11 & 17 Jun & \multicolumn{9}{|c|}{ 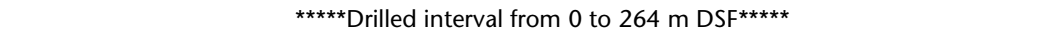 } \\
\hline $2 \mathrm{R}$ & 17 Jun & 2125 & 264 & 273.1 & 9.1 & 264 & 273.74 & 9.74 & 107 & 8 \\
\hline $3 \mathrm{R}$ & 17 Jun & 2325 & 273.1 & 282.8 & 9.7 & 273.1 & 280.37 & 7.27 & 75 & 6 \\
\hline $4 \mathrm{R}$ & 18 Jun & 0110 & 282.8 & 292.5 & 9.7 & 282.8 & 289.62 & 6.82 & 70 & 6 \\
\hline $5 \mathrm{R}$ & 18 Jun & 0255 & 292.5 & 302.2 & 9.7 & 292.5 & 297.25 & 4.75 & 49 & 5 \\
\hline 61 & 18 Jun & \multicolumn{9}{|c|}{ 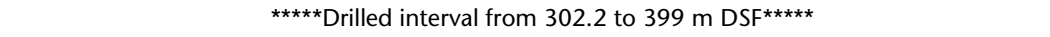 } \\
\hline $7 \mathrm{R}$ & 18 Jun & 1100 & 399 & 408.7 & 9.7 & 399 & 402.23 & 3.23 & 33 & 4 \\
\hline $8 \mathrm{R}$ & 18 Jun & 1255 & 408.7 & 418.4 & 9.7 & 408.7 & 418.32 & 9.62 & 99 & 8 \\
\hline $9 \mathrm{R}$ & 18 Jun & 1440 & 418.4 & 428.1 & 9.7 & 418.4 & 425.29 & 6.89 & 71 & 6 \\
\hline $10 \mathrm{R}$ & 18 Jun & 1620 & 428.1 & 437.8 & 9.7 & 428.1 & 433.31 & 5.21 & 54 & 5 \\
\hline $11 \mathrm{R}$ & 18 Jun & 1820 & 437.8 & 447.5 & 9.7 & 437.8 & 440.09 & 2.29 & 24 & 3 \\
\hline $12 \mathrm{R}$ & 18 Jun & 2000 & 447.5 & 457.2 & 9.7 & 447.5 & 447.98 & 0.48 & 5 & 2 \\
\hline $13 \mathrm{R}$ & 18 Jun & 2140 & 457.2 & 466.9 & 9.7 & 457.2 & 460.4 & 3.2 & 33 & 3 \\
\hline $14 \mathrm{R}$ & 18 Jun & 2330 & 466.9 & 476.6 & 9.7 & 466.9 & 468.72 & 1.82 & 19 & 3 \\
\hline $15 R$ & 19 Jun & 0110 & 476.6 & 486.3 & 9.7 & 476.6 & 486.24 & 9.64 & 99 & 8 \\
\hline $16 \mathrm{R}$ & 19 Jun & 0250 & 486.3 & 496 & 9.7 & 486.3 & 489.54 & 3.24 & 33 & 4 \\
\hline $17 \mathrm{R}$ & 19 Jun & 0425 & 496 & 505.7 & 9.7 & 496 & 501.75 & 5.75 & 59 & 5 \\
\hline $18 \mathrm{R}$ & 19 Jun & 0620 & 505.7 & 515.4 & 9.7 & 505.7 & 510.1 & 4.4 & 45 & 4 \\
\hline $19 \mathrm{R}$ & 19 Jun & 0800 & 515.4 & 525.1 & 9.7 & 515.4 & 520.04 & 4.64 & 48 & 4 \\
\hline $20 \mathrm{R}$ & 19 Jun & 0935 & 525.1 & 534.8 & 9.7 & 525.1 & 527.72 & 2.62 & 27 & 3 \\
\hline $21 \mathrm{R}$ & 19 Jun & 1115 & 534.8 & 544.5 & 9.7 & 534.8 & 535.55 & 0.75 & 8 & 2 \\
\hline $22 \mathrm{R}$ & 19 Jun & 1320 & 544.5 & 554.2 & 9.7 & 544.5 & 545.39 & 0.89 & 9 & 2 \\
\hline $23 \mathrm{R}$ & 19 Jun & 1500 & 554.2 & 563.9 & 9.7 & 554.2 & 555.44 & 1.24 & 13 & 2 \\
\hline $24 \mathrm{R}$ & 19 Jun & 1700 & 563.9 & 573.6 & 9.7 & 563.9 & 566.45 & 2.55 & 26 & 3 \\
\hline $25 \mathrm{R}$ & 19 Jun & 1840 & 573.6 & 583.3 & 9.7 & 573.6 & 576.14 & 2.54 & 26 & 3 \\
\hline $26 \mathrm{R}$ & 19 Jun & 2025 & 583.3 & 593 & 9.7 & 583.3 & 587.46 & 4.16 & 43 & 4 \\
\hline $27 \mathrm{R}$ & 19 Jun & 2210 & 593 & 602.7 & 9.7 & 593 & 597.68 & 4.68 & 48 & 5 \\
\hline $28 \mathrm{R}$ & 19 Jun & 2350 & 602.7 & 612.4 & 9.7 & 602.7 & 604.81 & 2.11 & 22 & 3 \\
\hline $29 \mathrm{R}$ & 20 Jun & 0130 & 612.4 & 622.1 & 9.7 & 612.4 & 619.09 & 6.69 & 69 & 6 \\
\hline $30 \mathrm{R}$ & 20 Jun & 0310 & 622.1 & 631.8 & 9.7 & 622.1 & 623.57 & 1.47 & 15 & 2 \\
\hline $31 \mathrm{R}$ & 20 Jun & 0450 & 631.8 & 641.5 & 9.7 & 631.8 & 633.3 & 1.5 & 15 & 2 \\
\hline $32 \mathrm{R}$ & 20 Jun & 0620 & 641.5 & 651.2 & 9.7 & 641.5 & 645.14 & 3.64 & 38 & 4 \\
\hline $33 \mathrm{R}$ & 20 Jun & 0950 & 651.2 & 655 & 3.8 & 651.2 & 654.84 & 0 & 0 & 0 \\
\hline $34 \mathrm{R}$ & 20 Jun & 1215 & 655 & 661 & 6 & 655 & 655.12 & 0.12 & 2 & 1 \\
\hline $35 \mathrm{R}$ & 20 Jun & 1400 & 661 & 670.7 & 9.7 & 661 & 665.19 & 4.19 & 43 & 4 \\
\hline
\end{tabular}


Table T1 (continued).

\begin{tabular}{|c|c|c|c|c|c|c|c|c|c|c|c|}
\hline \multirow[b]{2}{*}{ Core } & \multirow[b]{2}{*}{$\begin{array}{c}\text { Date } \\
(2013)\end{array}$} & \multirow[b]{2}{*}{$\begin{array}{l}\text { UTC time } \\
\text { (h) }\end{array}$} & \multicolumn{2}{|c|}{ Depth DSF (m) } & \multirow[b]{2}{*}{$\begin{array}{l}\text { Interval } \\
\text { advanced } \\
\text { (m) }\end{array}$} & \multicolumn{2}{|c|}{ Depth CSF (m) } & \multirow{2}{*}{$\begin{array}{l}\text { Length } \\
\text { of core } \\
\text { recovered } \\
\text { (m) }\end{array}$} & \multirow[b]{2}{*}{$\begin{array}{c}\text { Recovery } \\
\text { (\%) }\end{array}$} & \multirow[b]{2}{*}{$\begin{array}{l}\text { Sections } \\
(N)\end{array}$} & \multirow[b]{2}{*}{$\begin{array}{c}\mathrm{APC} \\
\text { system }\end{array}$} \\
\hline & & & $\begin{array}{c}\text { Top } \\
\text { of cored } \\
\text { interval }\end{array}$ & $\begin{array}{l}\text { Bottom } \\
\text { of cored } \\
\text { interval }\end{array}$ & & $\begin{array}{c}\text { Top } \\
\text { of cored } \\
\text { interval }\end{array}$ & $\begin{array}{l}\text { Bottom } \\
\text { of cored } \\
\text { interval }\end{array}$ & & & & \\
\hline $36 \mathrm{R}$ & 20 Jun & 1530 & 670.7 & 680.4 & 9.7 & 670.7 & 673.37 & 2.67 & 28 & 3 & \\
\hline $37 R$ & 20 Jun & 1710 & 680.4 & 690.1 & 9.7 & 680.4 & 683.01 & 2.61 & 27 & 3 & \\
\hline $38 \mathrm{R}$ & 20 Jun & 1900 & 690.1 & 699.8 & 9.7 & 690.1 & 695.57 & 5.47 & 56 & 5 & \\
\hline $39 R$ & 20 Jun & 2115 & 699.8 & 709.5 & 9.7 & 699.8 & 707.83 & 8.03 & 83 & 8 & \\
\hline
\end{tabular}

$\mathrm{DSF}=$ drilling depth below seafloor, $\mathrm{CSF}=$ core depth below seafloor. Core: $1=$ drilled interval, $\mathrm{H}=$ advanced piston corer (APC) core, $\mathrm{X}=$ extended core barrel core, $\mathrm{R}=$ rotary core barrel core. 
Table T2. Summary of observed lithofacies, Site U1417. (Continued on next two pages.)

\begin{tabular}{|c|c|c|c|c|c|c|}
\hline Main facies & Subfacies & Facies & Description & Marine microfossils & $\begin{array}{l}\text { Lithostratigraphic } \\
\text { unit }\end{array}$ & $\begin{array}{l}\text { Tentative depositional } \\
\text { environment/diagenesis }\end{array}$ \\
\hline \multirow[t]{2}{*}{ Mud } & $\begin{array}{l}\text { Massive mud with } \\
\text { lonestones }\end{array}$ & $\mathrm{F} 1 \mathrm{a}$ & $\begin{array}{l}\text { Dark gray to (dark) greenish gray; } \\
\text { Bioturbated (none to heavy); } \\
\text { Occasionally calcareous bearing; } \\
\text { Occasionally diatom rich/bearing; } \\
\text { Lonestones of granule and pebble sizes occur in varying amounts; } \\
\text { Occasional color banding and black mottles; } \\
\text { Occasional sand pods; } \\
\text { Interbedded with Facies F1b, F2a, F2b, F3a, F3b, F3c, F4a, F4b, F4c, F4d, F5a, } \\
\quad \text { F5b, F5c, F6, F7, and F8. }\end{array}$ & Variable & $\begin{array}{l}\text { IA, IB, II, III, IV, } \\
\text { VA, VB, VC, VD, } \\
\text { VE, VG, VI }\end{array}$ & $\begin{array}{l}\text { Suspension fall-out, ice rafting, } \\
\text { or sediment gravity flows }\end{array}$ \\
\hline & $\begin{array}{l}\text { Massive mud } \\
\text { without lonestones }\end{array}$ & $\mathrm{F} 1 \mathrm{~b}$ & $\begin{array}{l}\text { Dark gray to (dark) greenish gray; } \\
\text { Bioturbated (none to heavy); } \\
\text { Occasional Zoophycos burrows; } \\
\text { Occasionally calcareous bearing; } \\
\text { Occasionally diatom rich/bearing; } \\
\text { Occasional color banding and black mottles; } \\
\text { Occasional silt pods/lenses; } \\
\text { Interbedded with Facies F1a, F2a, F2b, F3a, F3c, F4a, F4c, F4d, F5a, F5b, F5c, } \\
\quad \text { F6, and F7. }\end{array}$ & Diatoms may occur & $\begin{array}{l}\text { IA, IB, II, IV, VA, } \\
\text { VB, VC, VD, VE, } \\
\text { VG, VI }\end{array}$ & $\begin{array}{l}\text { Suspension fall-out, ice rafting, } \\
\text { or sediment gravity flows }\end{array}$ \\
\hline \multirow[t]{2}{*}{ Silt } & Silt & $\mathrm{F} 2 \mathrm{a}$ & $\begin{array}{l}\text { Dark gray to greenish gray; } \\
\text { Often interbedded with mud; } \\
\text { Sharp to gradational upper and lower contacts; } \\
\text { Diatoms may occur; } \\
\text { Interbedded with Facies F1a, F1b, F2b, F3a, F4d, F5a, F5b, F5c, F6, and F7. }\end{array}$ & Diatoms may occur & $\begin{array}{l}\mathrm{IA}, \mathrm{IB}, \mathrm{II}, \mathrm{VE}, \mathrm{VF}, \\
\mathrm{VG}, \mathrm{VH}, \mathrm{VI}\end{array}$ & Sediment gravity flows \\
\hline & $\begin{array}{l}\text { Interbedded silt and } \\
\text { mud }\end{array}$ & $\mathrm{F} 2 \mathrm{~b}$ & $\begin{array}{l}\text { Dark gray to greenish gray; } \\
\text { Facies thickness } 2 \text { to } 360 \mathrm{~cm} \text {; } \\
\text { Occasional color banding; } \\
\text { None to moderate bioturbation; } \\
\text { Occasionally with terrestrial organic components; } \\
\text { Interbedded with Facies F1a, F1b, F2a, F3a, F4d, F4e, F4f, F6, and F8. }\end{array}$ & Not documented & $I A, I I, V E$ & $\begin{array}{l}\text { Mud: suspension fall-out from } \\
\text { surface water plumes and } \\
\text { from sediment gravity flows } \\
\text { Silt: sediment gravity flows }\end{array}$ \\
\hline \multirow[t]{3}{*}{ Sand } & $\begin{array}{l}\text { Very fine to coarse } \\
\text { sand }\end{array}$ & $\mathrm{F} 3 \mathrm{a}$ & $\begin{array}{l}\text { Dark gray to gray; } \\
\text { Bed thickness from } 1 \text { to } 5 \mathrm{~cm} \text {, occasionally thicker; } \\
\text { Massive and normal grading; } \\
\text { Sharp and frequently erosional lower contacts; } \\
\text { Gradational and sharp upper contacts; } \\
\text { Composition includes quartz and feldspar; } \\
\text { Interbedded with Facies F1a, F1b, F2a, F2b, F4b, F4d, F5a, F5b, F5c, and F6. }\end{array}$ & Not documented & $\begin{array}{l}\text { IA, IB, II, IV, VA, } \\
\text { VB, VC, VE, VG, } \\
\text { VI }\end{array}$ & Sediment gravity flows \\
\hline & $\begin{array}{l}\text { Medium to coarse } \\
\text { sand }\end{array}$ & $\mathrm{F} 3 \mathrm{~b}$ & $\begin{array}{l}\text { Dark gray to gray; } \\
\text { Bed thickness up to } 40 \mathrm{~cm} ; \\
\text { Rip-up clasts common; } \\
\text { Plant debris, organic matter, and diatoms may occur; } \\
\text { Sharp bases and sharp to gradational upper contacts; } \\
\text { Interbedded with Facies F1a and F4b. }\end{array}$ & Not documented & VA & Sediment gravity flows \\
\hline & $\begin{array}{l}\text { Interbedded sand } \\
\text { and mud }\end{array}$ & $\mathrm{F} 3 \mathrm{c}$ & $\begin{array}{l}\text { Dark gray to dark greenish gray; } \\
\text { Facies thickness } 7-710 \mathrm{~cm} \text {; } \\
\text { Partly diatom bearing; } \\
\text { None to moderate bioturbation; } \\
\text { Partly with volcanic ash; } \\
\text { Occasional color banding; } \\
\text { Lonestones may occur; } \\
\text { Interbedded with Facies } \mathrm{F} 1 \mathrm{a}, \mathrm{F} 1 \mathrm{~b}, \mathrm{~F} 5 \mathrm{a}, \mathrm{F} 5 \mathrm{~b}, \mathrm{~F} 5 \mathrm{~b}, \mathrm{~F} 6 \text {, and F7. }\end{array}$ & Diatoms may occur & IB, II, VA & $\begin{array}{l}\text { Suspension fall-out from } \\
\text { surface water plumes (mud), } \\
\text { ice rafting (mud, sand, } \\
\text { lonestones), and sediment } \\
\text { gravity flows (sand, mud) }\end{array}$ \\
\hline
\end{tabular}


Table T2 (continued). (Continued on next page.)

\begin{tabular}{|c|c|c|c|c|c|c|}
\hline Main facies & Subfacies & Facies & Description & Marine microfossils & $\begin{array}{c}\text { Lithostratigraphic } \\
\text { unit }\end{array}$ & $\begin{array}{l}\text { Tentative depositional } \\
\text { environment/diagenesis }\end{array}$ \\
\hline \multirow[t]{4}{*}{ Diamict } & Muddy diamict & $\mathrm{F} 4 \mathrm{a}$ & $\begin{array}{l}\text { Dark gray; } \\
\text { Muddy matrix; } \\
\text { Clast concentration variable; } \\
\text { Thin bedded or pods; } \\
\text { Lower contacts are gradational; } \\
\text { Upper contacts are sharp and defined by concentration of clasts; } \\
\text { Granule and small pebble clasts are commonly subangular to subrounded; } \\
\text { Interbedded with Facies F1a and F5c }\end{array}$ & Not documented & $\mid \mathrm{B}, \mathrm{II}$ & $\begin{array}{l}\text { Suspension settling and ice } \\
\text { rafting (mainly by icebergs) }\end{array}$ \\
\hline & $\begin{array}{l}\text { Muddy and sandy } \\
\text { diamict with lithic } \\
\text { and mud clasts } \\
\text { and/or terrigenous } \\
\text { organic } \\
\text { components }\end{array}$ & $\mathrm{F} 4 \mathrm{~b}$ & $\begin{array}{l}\text { Dark gray; } \\
\text { Mud to sand matrix; } \\
\text { Bed thickness up to } 40 \mathrm{~cm} \text {; } \\
\text { Sharp upper and lower contacts; } \\
\text { Lithic and mud clasts up to } 3 \mathrm{~cm} ; \\
\text { Occasional plant debris and terrestrial organic components (coal?); } \\
\text { Interbedded with Facies F1a, F1b, F3a, F3b, F5a, F5b, F7, and F8 (in disturbed } \\
\text { sequence). }\end{array}$ & $\begin{array}{l}\text { Diatoms (partly } \\
\text { freshwater) }\end{array}$ & $\begin{array}{l}\mathrm{VA}, \mathrm{VC}, \mathrm{VD}, \mathrm{VE}, \\
\mathrm{VF}, \mathrm{VG}, \mathrm{VI}\end{array}$ & Sediment gravity flows \\
\hline & Breccia & $\mathrm{F} 4 \mathrm{c}$ & $\begin{array}{l}\text { Dark gray matrix; } \\
\text { Sandy mud matrix; } \\
\text { Bed thickness typically } 100 \mathrm{~cm} ; \\
\text { Sharp erosive lower contacts; } \\
\text { Gradational upper contacts; } \\
\text { Most often clasts of indurated diatom ooze; } \\
\text { Interbedded with Facies F1a and 5a. }\end{array}$ & Not documented & VF & $\begin{array}{l}\text { Sediment gravity flows (e.g., } \\
\text { slump) }\end{array}$ \\
\hline & $\begin{array}{l}\text { Interbedded mud } \\
\text { and diamict }\end{array}$ & $\mathrm{F} 4 \mathrm{~d}$ & $\begin{array}{l}\text { Dark gray to greenish gray; } \\
\text { Occasional color banding and parallel lamination; } \\
\text { None to moderate bioturbation; } \\
\text { Occasionally calcareous bearing; } \\
\text { Interbedded with Facies F1a, F1b, F2a, F2b, F3a, F4e, F5b, F5c, and F7. }\end{array}$ & Not documented & III, VC, VE & $\begin{array}{l}\text { Suspension settling and ice } \\
\text { rafting (icebergs and/or sea } \\
\text { ice) }\end{array}$ \\
\hline Diatom ooze & & F5a & $\begin{array}{l}\text { Greenish gray; } \\
20 \mathrm{~cm} \text { to } 1.5 \mathrm{~m} \text {; } \\
\text { Bioturbation (including Zoophycos burrows); } \\
\text { Sharp to gradational upper and lower contacts; } \\
\text { Interbedded with Facies F1a, F1b, F2a, F3a, F3c, F4b, F4c, F5b, and F6. }\end{array}$ & $\begin{array}{l}\text { Diatoms and other } \\
\text { biosiliceous material; } \\
\text { occasional carbonate } \\
\text { (foraminifers and } \\
\text { coccolithophores) }\end{array}$ & $\begin{array}{l}I A, I B, I I, V A, V B, \\
V D, V F, V H, V J\end{array}$ & $\begin{array}{l}\text { High-productivity environment } \\
\text { and/or low terrigenous input } \\
\text { and/or better preservation }\end{array}$ \\
\hline $\begin{array}{l}\text { Biosiliceous ooze; } \\
\text { biosiliceous-rich/ } \\
\text { bearing mud and } \\
\text { sand; mud with } \\
\text { diatoms/biosilica }\end{array}$ & & $\mathrm{F} 5 \mathrm{~b}$ & $\begin{array}{l}\text { (Very) dark gray to (dark) greenish gray and brown; } \\
\text { Facies thickness } 2-445 \mathrm{~cm} ; \\
\text { Mostly mud, rarely sand; } \\
\text { Diatom and biosiliceous rich/bearing; } \\
\text { Lonestones are absent or present; } \\
\text { Occasional color banding; } \\
\text { Partly mottled; } \\
\text { Occasionally laminated; } \\
\text { None to heavy bioturbation; } \\
\text { Interbedded with Facies F1a, F1b, F2a, F3a, F3c, F4b, F5a, F5c, F6, F7, and F8. }\end{array}$ & $\begin{array}{l}\text { Diatoms and other } \\
\text { biosiliceous material }\end{array}$ & $\begin{array}{l}\text { IA, IB, II, IV, VA, } \\
\text { VB, VC, VD, VE, } \\
\text { VH, VI }\end{array}$ & $\begin{array}{l}\text { High-productivity environment } \\
\text { and/or low terrigenous input } \\
\text { and/or better preservation }\end{array}$ \\
\hline $\begin{array}{l}\text { Calcareous/ } \\
\text { carbonate-bearing/ } \\
\text { rich mud, silt, } \\
\text { sand, diamict, and/ } \\
\text { or diatom ooze }\end{array}$ & & $\mathrm{F} 5 \mathrm{c}$ & $\begin{array}{l}\text { (Very) dark gray to greenish gray; } \\
\text { Facies thickness 3-316 cm; } \\
\text { Occasionally with volcanic ash; } \\
\text { None to heavy bioturbation; } \\
\text { Occasional color banding and lamination; } \\
\text { Interbedded with Facies F1a, F1b, F2a, F3a, F4a, F4b, F5b, and F8. }\end{array}$ & $\begin{array}{l}\text { Foraminifers; } \\
\text { occasionally diatoms }\end{array}$ & $\begin{array}{l}\text { II, III, IV, VB, VE, } \\
\text { VI }\end{array}$ & $\begin{array}{l}\text { Temporarily increased } \\
\text { productivity and/or reduced } \\
\text { suspension settling and/or } \\
\text { better preservation }\end{array}$ \\
\hline Ash & Volcanic ash & F6 & $\begin{array}{l}\text { Usually gray to brown; } \\
\text { Bed thickness typically } 1-5 \mathrm{~cm} ; \\
\text { Sharp lower contacts; } \\
\text { Sharp to gradational upper contacts; } \\
\text { Primarily vitric shards (glass); } \\
\text { Some intervals affected by bioturbation; } \\
\text { Often interbedded with Facies F1a, F1b, F2a, F3a, F3c, F5a, and F5b. }\end{array}$ & Not documented & $I A, I B, I I, V A$ & $\begin{array}{l}\text { Suspension settling after } \\
\text { subaerial eruptions }\end{array}$ \\
\hline
\end{tabular}




\begin{tabular}{|c|c|c|c|c|c|c|}
\hline Main facies & Subfacies & Facies & Description & Marine microfossils & $\begin{array}{c}\text { Lithostratigraphic } \\
\text { unit }\end{array}$ & $\begin{array}{l}\text { Tentative depositional } \\
\text { environment/diagenesis }\end{array}$ \\
\hline $\begin{array}{l}\text { Volcaniclastic mud, } \\
\text { sand, diamict and/ } \\
\text { or ooze }\end{array}$ & & F7 & $\begin{array}{l}\text { Usually grayish, greenish, or brownish; } \\
\text { Bed thickness typically } 1-5 \mathrm{~cm} \text {; } \\
\text { Sharp and frequently erosive lower contacts; } \\
\text { Gradational to sharp upper contacts; } \\
\text { Primarily vitric shards (glass); } \\
\text { Some intervals affected by bioturbation; } \\
\text { Often interbedded with Facies F1a, F1b, F2a, F3c, F4d, F5b, and F7. }\end{array}$ & Diatoms & $I A, I B, I I, I I I, I V$ & $\begin{array}{l}\text { Volcanic detritus either } \\
\text { bioturbated or reworked/ } \\
\text { redeposited by sediment } \\
\text { gravity flows }\end{array}$ \\
\hline Rock & & F8 & $\begin{array}{l}\text { Siltstone with carbonate cement; } \\
\text { Often interbedded with Facies F1a, F2b, F4b, F5b, and F5c. }\end{array}$ & & $\mathrm{VC}, \mathrm{VE}, \mathrm{VH}$ & $\begin{array}{l}\text { In situ carbonate } \\
\text { sedimentation }\end{array}$ \\
\hline
\end{tabular}

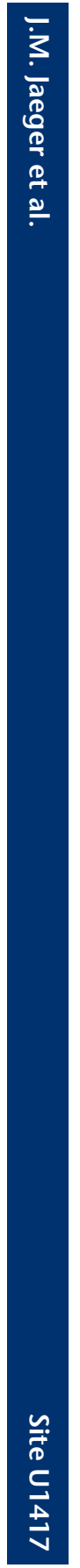


Table T3. Distribution of lithostratigraphic units and associated facies, Site U1417.

\begin{tabular}{|c|c|c|c|c|c|}
\hline $\begin{array}{l}\text { Lithostratigraphic units } \\
\text { and associated facies }\end{array}$ & Hole U1417A & Hole U1417B & Hole U1417C & Hole U1417D & Hole U1417E \\
\hline $\begin{array}{l}\text { Subunit IA } \\
\text { F1a, F1b, F2a, F2b, F3a, F5a, F5b, } \\
\text { F6, F7 }\end{array}$ & $\begin{array}{l}0-77.0 \mathrm{~m} \text { CSF-A; } \\
\text { Interval } 1 \mathrm{H}-1,0 \mathrm{~cm}, \text { to } 11 \mathrm{H}-2,18 \\
\mathrm{~cm}\end{array}$ & $\begin{array}{l}\text { 0-79.4 m CSF-A; } \\
\text { Interval } 1 \mathrm{H}-1,0 \mathrm{~cm} \text {, to } 10 \mathrm{H}-2 \text {, } \\
131 \mathrm{~cm}\end{array}$ & $\begin{array}{l}0-77.0 \mathrm{~m} \text { CSF-A; } \\
\text { Interval } 2 \mathrm{H}-1,0 \mathrm{~cm} \text {, to } 10 \mathrm{H}-2,48 \\
\quad \mathrm{~cm}\end{array}$ & $\begin{array}{l}0-78.8 \mathrm{~m} \text { CSF-A; } \\
\text { Interval } 1 \mathrm{H}-1,0 \mathrm{~cm} \text {, to } 10 \mathrm{H}-3,38 \\
\quad \mathrm{~cm}\end{array}$ & Drilled interval \\
\hline $\begin{array}{l}\text { Subunit IB } \\
\text { F1a, F1b, F2a, F3a, F3c, F4a, F5a, } \\
\text { F5b, F6, F7 }\end{array}$ & $\begin{array}{l}77.0-168.0 \mathrm{~m} \text { CSF-A; } \\
\text { Interval } 11 \mathrm{H}-2,18 \mathrm{~cm} \text {, to } 22 \mathrm{H}- \\
\quad \mathrm{CC}, 38 \mathrm{~cm}\end{array}$ & $\begin{array}{l}79.4-151.9 \mathrm{~m} \mathrm{CSF}-\mathrm{A} \text {; } \\
\text { Interval } 10 \mathrm{H}-2,131 \mathrm{~cm} \text {, to } 17 \mathrm{H}- \\
\mathrm{CC}, 17 \mathrm{~cm}\end{array}$ & $\begin{array}{l}77.0-154.1 \mathrm{~m} \text { CSF-A; } \\
\text { Interval } 10 \mathrm{H}-2,48 \mathrm{~cm} \text {, to } 18 \mathrm{H}-3, \\
18 \mathrm{~cm}\end{array}$ & $\begin{array}{l}78.8-166.3 \mathrm{~m} \text { CSF-A; } \\
\text { Interval } 10 \mathrm{H}-3,38 \mathrm{~cm} \text {, to } 22 \mathrm{H}-1 \\
0 \mathrm{~cm}\end{array}$ & Drilled interval \\
\hline $\begin{array}{l}\text { Unit II } \\
\text { F1a, F1b, F2a, F2b, F3a, F3c, F5a, } \\
\text { F5b, F5c, F6, F7 }\end{array}$ & & $\begin{array}{l}\text { 151.9-256.2 m CSF-A; } \\
\text { Interval 17H-CC, } 17 \mathrm{~cm} \text {, to } 37 \mathrm{X} \text { - } \\
\quad \mathrm{CC}, 30.5 \mathrm{~cm}\end{array}$ & $\begin{array}{l}154.1-226.0 \mathrm{~m} \text { CSF-A; } \\
\text { Interval } 18 \mathrm{H}-3,18 \mathrm{~cm} \text {, to } 29 \mathrm{H}- \\
\quad \mathrm{CC}, 7 \mathrm{~cm}\end{array}$ & $\begin{array}{l}166.3-263.5 \mathrm{~m} \text { CSF-A; } \\
\text { Interval } 22 \mathrm{H}-1,0 \mathrm{~cm} \text {, to } 42 \mathrm{X}-1 \text {, } \\
85 \mathrm{~cm}\end{array}$ & Drilled interval \\
\hline $\begin{array}{l}\text { Unit III } \\
\text { F1a, F1b, F4a, F4d, F5c, F7 }\end{array}$ & & $\begin{array}{l}256.2-291.3 \mathrm{~m} \text { CSF-A; } \\
\text { Interval } 38 \mathrm{X}-1,0 \mathrm{~cm} \text {, to } 41 \mathrm{X}-1, \\
\quad 40 \mathrm{~cm}\end{array}$ & & $\begin{array}{l}263.5-296.6 \mathrm{~m} \text { CSF-A; } \\
\text { Interval } 42 \mathrm{X}-1,85 \mathrm{~cm} \text {, to } 46 \mathrm{X}-1 \text {, } \\
92 \mathrm{~cm}\end{array}$ & $\begin{array}{l}264.1-297.3 \mathrm{~m} \mathrm{CSF}-\mathrm{A} \text {; } \\
\text { Interval } 2 \mathrm{R}-1,7.5 \mathrm{~cm} \text {, to } 5 \mathrm{R}-\mathrm{CC} \text {, } \\
10 \mathrm{~cm}\end{array}$ \\
\hline $\begin{array}{l}\text { Unit IV } \\
\text { F1a, F1b, F3a, F5b, F5c, F7 }\end{array}$ & & $\begin{array}{l}291.3-350.0 \mathrm{~m} \text { CSF-A; } \\
\text { Interval } 41 \mathrm{X}-1,40 \mathrm{~cm} \text {, to } 47 \mathrm{X}-\mathrm{CC} \text {, } \\
26 \mathrm{~cm}\end{array}$ & & $\begin{array}{l}296.6-335.1 \mathrm{~m} \text { CSF-A; } \\
\text { Interval } 46 \mathrm{X}-1,92 \mathrm{~cm} \text {, to } 50 \mathrm{X}-1 \text {, } \\
63 \mathrm{~cm}\end{array}$ & Drilled interval \\
\hline $\begin{array}{l}\text { Subunit VA } \\
\text { F1b, F3a, F3b, F3c, F4a, F4b, F5a, } \\
\quad \text { F5b, F5c, F6 }\end{array}$ & & & & $\begin{array}{l}335.1-394.3 \mathrm{~m} \text { CSF-A; } \\
\text { Interval 50X-1, } 63 \mathrm{~cm} \text {, to } 56 \mathrm{X}-\mathrm{CC} \text {, } \\
19 \mathrm{~cm}\end{array}$ & Drilled interval \\
\hline $\begin{array}{l}\text { Subunit VB } \\
\text { F1b, F5a, F5b, F7 }\end{array}$ & & & & $\begin{array}{l}394.3-432.0 \mathrm{~m} \text { CSF-A; } \\
\text { Interval } 56 \mathrm{X}-\mathrm{CC}, 19 \mathrm{~cm} \text {, to } 60 \mathrm{X}- \\
\quad \mathrm{CC}, 10 \mathrm{~cm}\end{array}$ & $\begin{array}{l}399.0-431.0 \mathrm{~m} \text { CSF-A; } \\
\text { Interval 7R-1, } 0 \mathrm{~cm} \text {, to } 10 \mathrm{R}-3,0 \\
\mathrm{~cm}\end{array}$ \\
\hline Subunit VC & & & & $432.0-461.5$ CSF-A; & 431.0-477.7 m CSF-A; \\
\hline $\begin{array}{l}\text { F1a, F1b, F2a, F4a, F4b, F4d, F5b, } \\
\text { F8 }\end{array}$ & & & & $\begin{array}{l}\text { Interval } 60 \mathrm{X}-\mathrm{CC}, 10 \mathrm{~cm} \text {, to } 65 \mathrm{X} \text { - } \\
\mathrm{CC}, 21 \mathrm{~cm}\end{array}$ & $\begin{array}{l}\text { Interval } 10 \mathrm{R}-3,0 \mathrm{~cm} \text {, to } 15 \mathrm{R}-1,66 \\
\mathrm{~cm}\end{array}$ \\
\hline $\begin{array}{l}\text { Subunit VD } \\
\text { F1b, F4a, F5a }\end{array}$ & & & & & $\begin{array}{l}477.7-484.6 \mathrm{~m} \text { CSF-A; } \\
\text { Interval } 15 \mathrm{R}-1,66 \mathrm{~cm} \text {, to } 15 \mathrm{R}-6 \text {, } \\
55 \mathrm{~cm}\end{array}$ \\
\hline $\begin{array}{l}\text { Subunit VE } \\
\text { F1a, F1b, F2a, F2b, F3a, F3b, F3c, } \\
\text { F4b, F4d, F5b, F5c, F7, F8 }\end{array}$ & & & & & $\begin{array}{l}484.6-615.4 \mathrm{~m} \mathrm{CSF}-\mathrm{A} \text {; } \\
\text { Interval } 15 \mathrm{R}-6,55 \mathrm{~cm} \text {, to } 29 \mathrm{R}-3 \text {, } \\
11 \mathrm{~cm}\end{array}$ \\
\hline $\begin{array}{l}\text { Subunit VF } \\
\text { F2a, F4c, F5a }\end{array}$ & & & & & $\begin{array}{l}\text { 615.4-619.0 m CSF-A; } \\
\text { Interval } 29 \mathrm{R}-3,11 \mathrm{~cm} \text {, to } 29 \mathrm{R}-\mathrm{CC} \\
17 \mathrm{~cm}\end{array}$ \\
\hline $\begin{array}{l}\text { Subunit VG } \\
\text { F1b, F3a, F4b, F8 }\end{array}$ & & & & & $\begin{array}{l}619.0-642.8 \mathrm{~m} \mathrm{CSF}-\mathrm{A} \text {; } \\
\text { Interval } 29 \mathrm{R}-\mathrm{CC}, 17 \mathrm{~cm} \text {, to } 32 \mathrm{R}-2 \\
0 \mathrm{~cm}\end{array}$ \\
\hline $\begin{array}{l}\text { Subunit VH } \\
\text { F5b, F8 }\end{array}$ & & & & & $\begin{array}{l}\text { 642.8-661.5 m CSF-A; } \\
\text { Interval 32R-2, } 0 \mathrm{~cm} \text {, to } 35 \mathrm{R}-1,53 \\
\mathrm{~cm}\end{array}$ \\
\hline $\begin{array}{l}\text { Subunit VI } \\
F 1 b, F 2 a, F 3 a, F 4 b, F 5 b, F 5 c\end{array}$ & & & & & $\begin{array}{l}661.5-705.9 \mathrm{~m} \mathrm{CSF}-\mathrm{A} \\
\text { Interval } 35 \mathrm{R}-1,53 \mathrm{~cm} \text {, to } 39 \mathrm{R}-6 \text {, } \\
13 \mathrm{~cm}\end{array}$ \\
\hline $\begin{array}{l}\text { Subunit VJ } \\
\text { F1b, F5a }\end{array}$ & & & & & $\begin{array}{l}\text { 705.9-708.0 m CSF-A; } \\
\text { Interval } 39 \mathrm{R}-6,13 \mathrm{~cm} \text {, to } 39 \mathrm{R}-\mathrm{CC} \\
23 \mathrm{~cm}\end{array}$ \\
\hline
\end{tabular}


Table T4. X-ray diffraction mineral composition, Holes U1417A, U1417C, U1417D, and U1417E. (Continued on next page.)

\begin{tabular}{|c|c|c|c|c|c|c|c|c|c|c|}
\hline \multirow{2}{*}{$\begin{array}{l}\text { Hole, core, section, } \\
\text { interval }(\mathrm{cm})\end{array}$} & \multicolumn{2}{|c|}{ Top depth (m) } & \multirow{2}{*}{$\begin{array}{c}\text { Mica } \\
\text { (counts) }\end{array}$} & \multirow{2}{*}{$\begin{array}{l}\text { Hornblende } \\
\text { (counts) }\end{array}$} & \multirow{2}{*}{$\begin{array}{c}\text { Chlorite + } \\
\text { kaolinite } \\
\text { (counts) }\end{array}$} & \multirow{2}{*}{$\begin{array}{c}\text { Total clays } \\
\text { (counts) }\end{array}$} & \multirow{2}{*}{$\begin{array}{c}\text { Quartz } \\
\text { (counts) }\end{array}$} & \multirow{2}{*}{$\begin{array}{l}\text { Plagioclase } \\
\text { (counts) }\end{array}$} & \multirow{2}{*}{$\begin{array}{l}\text { Calcite } \\
\text { (counts) }\end{array}$} & \\
\hline & CSF-A & CCSF-B & & & & & & & & (counts) \\
\hline $341-$ & & & & & & & & & & \\
\hline U1417D-1H-1, 4-5 & 0.04 & 0.03 & 3,896 & 3,580 & 5,019 & 2,903 & 4,212 & 5,054 & NA & 2,187 \\
\hline U1417A-1H-1, 24-25 & 0.24 & 0.23 & 7,652 & 5,897 & 12,074 & 2,794 & 4,844 & 6,318 & 2,383 & 2,464 \\
\hline U1417D-1H-1, 31-32 & 0.31 & 0.27 & 3,545 & 3,184 & 3,756 & 2,738 & 3,313 & 6,599 & 3,068 & 2,457 \\
\hline U1417D-1H-1, 65-66 & 0.65 & 0.56 & 3,373 & 2,980 & 3,282 & 2,780 & 3,931 & 5,546 & 3,545 & 2,327 \\
\hline U1417A-1H-1, 71-72 & 0.71 & 0.63 & 5,054 & 4,072 & 5,756 & 3,043 & 5,230 & 6,915 & 2,840 & 2,397 \\
\hline U1417D-1H-1, 100-101 & 1.01 & 0.87 & 5,546 & 4,317 & 6,950 & 3,268 & 5,265 & 6,423 & 2,864 & 2,559 \\
\hline U1417A-1H-2, 72-73 & 2.22 & 1.94 & 5,230 & 4,072 & 7,266 & 3,022 & 5,897 & 6,458 & 3,363 & 2,478 \\
\hline U1417D-1H-3, 14-15 & 3.14 & 2.72 & 3,468 & 2,710 & 4,317 & 2,955 & 4,352 & 5,827 & 2,562 & 2,211 \\
\hline U1417A-2H-1, 80-81 & 6.20 & 7.59 & 5,265 & 3,475 & 7,511 & 3,313 & 6,529 & 6,388 & 2,847 & 2,415 \\
\hline U1417A-2H-3, 50-51 & 8.90 & 9.93 & 8,178 & 3,686 & 13,514 & 3,184 & 6,037 & 6,458 & NA & 2,239 \\
\hline U1417A-3H-2, 65-66 & 17.05 & 18.29 & 4,633 & 3,756 & 6,423 & 3,250 & 6,143 & 6,809 & 2,783 & 2,422 \\
\hline U1417A-3H-6, 121-122 & 23.61 & 23.96 & 4,633 & 3,433 & 6,107 & 2,987 & 5,054 & 5,616 & 2,250 & 2,194 \\
\hline U1417A-4H-3, 48-49 & 27.88 & 28.01 & 8,143 & 5,090 & 12,074 & 3,127 & 6,529 & 7,090 & 2,348 & 2,590 \\
\hline U1417A-5H-3, 48-49 & 37.32 & 36.70 & 5,792 & 3,686 & 8,810 & 3,163 & 6,423 & 6,774 & 2,833 & 2,306 \\
\hline U1417A-6H-1, 46-47 & 43.86 & 42.18 & 9,126 & 5,721 & 13,619 & 2,917 & 5,511 & 7,160 & NA & 2,464 \\
\hline U1417A-7H-2, 61-62 & 47.01 & 43.88 & 12,671 & 5,265 & 20,885 & 3,047 & 6,423 & 7,757 & 2,324 & 2,482 \\
\hline U1417C-7H-3, 27-28 & 49.77 & 48.68 & 6,774 & 5,897 & 8,564 & 3,489 & 5,441 & 6,529 & NA & 2,984 \\
\hline U1417A-8H-2, 59-60 & 56.49 & 52.70 & 11,021 & 7,125 & 18,006 & 2,941 & 6,143 & 8,424 & NA & 2,492 \\
\hline U1417D-7H-2, 141-142 & 56.41 & 56.00 & 4,352 & 2,482 & 6,423 & 3,721 & 7,792 & 7,055 & 2,668 & 2,152 \\
\hline U1417A-9H-1, 129-130 & 58.19 & 57.65 & 5,546 & 3,756 & 8,003 & 3,268 & 6,143 & 6,318 & 2,931 & 2,436 \\
\hline U1417A-9H-4, 74-75 & 62.14 & 61.07 & 3,931 & 3,205 & 4,844 & 2,945 & 4,809 & 4,949 & 3,345 & 2,050 \\
\hline U1417A-9H-6, 58-59 & 64.98 & 63.52 & 4,984 & 4,598 & 7,055 & 3,187 & 5,160 & 6,248 & 2,819 & 2,696 \\
\hline U1417A-10H-3, 74-75 & 70.14 & 68.80 & 5,195 & 3,756 & 7,511 & 3,043 & 6,669 & 6,423 & 2,833 & 2,334 \\
\hline U1417A-11H-3, 31-32 & 79.21 & 79.80 & 6,248 & 6,985 & 11,408 & 3,057 & 5,862 & 6,950 & 2,601 & 2,910 \\
\hline U1417A-12H-3, 40-41 & 88.80 & 89.63 & 4,177 & 3,686 & 5,230 & 3,085 & 5,160 & 5,827 & 2,720 & 2,390 \\
\hline U1417A-13H-3, 60-61 & 98.50 & 99.47 & 10,319 & 4,809 & 16,883 & 3,345 & 7,441 & 7,827 & 2,966 & 2,840 \\
\hline U1417A-14H-3, 41-42 & 107.81 & 106.58 & 5,511 & 3,650 & 8,951 & 3,047 & 5,721 & 6,423 & NA & 2,552 \\
\hline U1417A-15H-2, 47-48 & 115.87 & 114.69 & 5,792 & 4,142 & 8,740 & 3,327 & 6,037 & 6,458 & 2,453 & 2,615 \\
\hline U1417A-16H-3, 43-44 & 126.83 & 124.72 & 9,126 & 4,774 & 15,233 & 3,036 & 5,897 & 7,898 & 2,345 & 2,418 \\
\hline U1417A-17H-3, 41-42 & 136.31 & 132.90 & 5,370 & 4,037 & 8,564 & 3,033 & 6,107 & 6,669 & NA & 2,475 \\
\hline U1417C-16H-4, 102-103 & 137.52 & 136.68 & 3,082 & 2,748 & 3,152 & 2,692 & 3,433 & 7,722 & 2,650 & 2,257 \\
\hline U1417A-18H-4, 88-89 & 146.83 & 142.36 & 4,528 & 3,391 & 5,932 & 3,064 & 5,546 & 5,827 & 2,594 & 2,260 \\
\hline U1417D-18H-1, 28-29 & 147.68 & 146.49 & 4,107 & 3,506 & 5,195 & 3,050 & 4,879 & 5,195 & 2,338 & 2,524 \\
\hline U1417C-17H-4, 17-18 & 146.17 & 146.73 & 4,177 & 3,405 & 3,791 & 3,317 & 4,177 & 4,984 & 2,703 & 2,517 \\
\hline U1417C-17H-4, 34-35 & 146.34 & 146.88 & 2,387 & NA & 1,955 & 2,696 & 2,790 & 4,423 & 2,629 & NA \\
\hline U1417C-17H-4, 67-68 & 146.67 & 147.17 & 5,265 & 4,212 & 6,880 & 2,910 & 5,090 & 5,511 & 2,562 & 2,327 \\
\hline U1417A-19H-2, 139-140 & 152.29 & 149.21 & 5,651 & 4,668 & 8,670 & 3,292 & 5,932 & 6,458 & 2,938 & 2,576 \\
\hline U1417D-18H-4, 52-53 & 152.42 & 150.59 & 5,125 & 3,896 & 7,968 & 3,261 & 6,423 & 6,634 & 2,903 & 2,496 \\
\hline U1417D-18H-6, 39-40 & 155.29 & 153.07 & 3,931 & 3,380 & 4,703 & 1,973 & 11,688 & 11,408 & 2,088 & 1,481 \\
\hline U1417D-18H-6, 109-110 & 155.99 & 153.67 & 4,914 & 3,931 & 4,352 & 3,721 & 6,388 & 6,072 & 3,001 & 3,292 \\
\hline U1417C-18H-2, 108-112 & 153.58 & 153.69 & 2,594 & 2,292 & 2,573 & 2,731 & 3,686 & 3,791 & 2,285 & 1,902 \\
\hline U1417C-18H-2, 132-137 & 153.82 & 153.90 & 6,423 & 2,148 & 10,881 & 2,731 & 9,547 & 22,218 & 2,001 & 1,527 \\
\hline U1417A-20H-1, 86-87 & 158.16 & 154.46 & 9,021 & 5,546 & 11,513 & 2,903 & 5,827 & 7,336 & NA & 2,604 \\
\hline U1417C-18H-4, 21-22 & 155.71 & 155.53 & 2,401 & 2,611 & 2,117 & 1,057 & 3,545 & 4,809 & 1,271 & 1,464 \\
\hline U1417A-21H-2, 83-84 & 160.73 & 159.80 & 5,721 & 4,879 & 6,283 & 3,275 & 5,125 & 6,353 & 2,812 & 2,752 \\
\hline U1417A-22H-2, 121-122 & 165.91 & 164.97 & 7,020 & 3,756 & 11,162 & 3,117 & 6,529 & 6,950 & NA & 2,296 \\
\hline U1417D-22H-2, 106-107 & 168.86 & 167.07 & 4,388 & 4,423 & 5,335 & 2,215 & 7,968 & 8,740 & 2,425 & 2,492 \\
\hline U1417D-22H-3, 80-81 & 170.10 & 168.14 & 5,405 & 4,037 & 5,125 & 3,510 & 5,511 & 6,388 & 2,868 & 2,731 \\
\hline U1417D-23H-1, 29-31 & 171.29 & 171.32 & 5,546 & 4,949 & 6,107 & 3,580 & 6,353 & 7,266 & 3,008 & 2,654 \\
\hline U1417D-23H-3, 88-89 & 174.88 & 174.42 & 5,967 & 4,528 & 7,020 & 3,120 & 6,002 & 6,774 & 2,815 & 2,450 \\
\hline U1417D-24H-1, 141-143 & 177.11 & 175.61 & 5,160 & 3,721 & 5,827 & 3,247 & 5,686 & 6,494 & 2,804 & 2,443 \\
\hline U1417D-25H-1, 30-32 & 180.70 & 178.40 & 5,019 & 4,177 & 5,370 & 3,412 & 5,405 & 6,143 & 2,941 & 2,794 \\
\hline U1417D-25H-2, 133-135 & 183.23 & 180.59 & 4,317 & 10,319 & 3,419 & 2,390 & 8,319 & 12,390 & 2,366 & 2,369 \\
\hline U1417D-32H-2, 38-39 & 205.78 & 206.40 & 6,950 & 4,493 & 9,968 & 3,264 & 5,335 & 6,178 & NA & 2,552 \\
\hline U1417D-34H-1, 94-95 & 210.34 & 210.23 & 4,668 & 3,461 & 5,756 & 3,436 & 5,616 & 6,002 & 2,815 & 2,527 \\
\hline U1417D-35H-2, 45-46 & 216.05 & 215.29 & 4,879 & 3,861 & 5,897 & 3,366 & 5,441 & 5,967 & NA & 2,443 \\
\hline U1417C-27H-2, 12-13 & 220.02 & 219.20 & 2,724 & 2,369 & 2,390 & 2,545 & 2,903 & 2,689 & 2,310 & 1,923 \\
\hline U1417D-36H-2, 50-51 & 220.80 & 219.32 & 5,160 & 3,422 & 6,353 & 3,447 & 6,423 & 6,704 & 2,931 & 2,327 \\
\hline U1417D-38X-1, 23-24 & 224.13 & 224.13 & 4,879 & 3,861 & 6,774 & 3,096 & 5,265 & 5,862 & 4,703 & 2,411 \\
\hline U1417D-39X-1, 133-135 & 234.93 & 234.93 & 4,844 & 5,300 & 5,054 & 2,088 & 8,003 & 8,459 & 3,650 & 2,503 \\
\hline U1417D-40X-3, 93-95 & 246.77 & 246.77 & 5,827 & 4,388 & 7,968 & 3,163 & 5,581 & 6,494 & 2,861 & 2,506 \\
\hline U1417D-41X-2, 35-37 & 254.85 & 254.85 & 6,458 & 5,195 & 8,775 & 3,043 & 5,897 & 7,125 & 3,163 & 2,464 \\
\hline U1417D-41X-5, 48-50 & 259.48 & 259.48 & 5,967 & NA & 7,827 & 3,457 & 6,529 & 6,634 & 3,159 & 2,246 \\
\hline U1417D-42X-1, 31-32 & 263.01 & 263.01 & 5,300 & 4,142 & 7,125 & 3,268 & 5,019 & 6,037 & 3,791 & 2,734 \\
\hline U1417D-42X-2, 127-128 & 265.47 & 265.47 & 2,955 & 2,450 & 2,699 & 2,601 & 3,650 & 3,721 & NA & 2,081 \\
\hline U1417D-42X-CC, 27-29 & 267.75 & 267.75 & 5,511 & 4,352 & 7,898 & 2,896 & 5,405 & 6,388 & 4,598 & 2,499 \\
\hline
\end{tabular}


Table T4 (continued).

\begin{tabular}{|c|c|c|c|c|c|c|c|c|c|c|}
\hline \multirow{2}{*}{$\begin{array}{l}\text { Hole, core, section, } \\
\text { interval }(\mathrm{cm})\end{array}$} & \multicolumn{2}{|c|}{ Top depth (m) } & \multirow{2}{*}{$\begin{array}{c}\text { Mica } \\
\text { (counts) }\end{array}$} & \multirow{2}{*}{$\begin{array}{l}\text { Hornblende } \\
\text { (counts) }\end{array}$} & \multirow{2}{*}{$\begin{array}{l}\text { Chlorite + } \\
\text { kaolinite } \\
\text { (counts) }\end{array}$} & \multirow{2}{*}{$\begin{array}{l}\text { Total clays } \\
\text { (counts) }\end{array}$} & \multirow{2}{*}{$\begin{array}{l}\text { Quartz } \\
\text { (counts) }\end{array}$} & \multirow{2}{*}{$\begin{array}{l}\text { Plagioclase } \\
\text { (counts) }\end{array}$} & \multirow{2}{*}{$\begin{array}{l}\text { Calcite } \\
\text { (counts) }\end{array}$} & \multirow{2}{*}{$\begin{array}{l}\text { Pyrite } \\
\text { (counts) }\end{array}$} \\
\hline & CSF-A & CCSF-B & & & & & & & & \\
\hline U1417D-44X-1, 81-83 & 282.91 & 282.91 & 5,265 & 4,282 & 7,371 & 2,959 & 5,792 & 6,704 & 3,071 & 2,738 \\
\hline U1417D-45X-1, 81-83 & 290.51 & 287.50 & 4,879 & 3,791 & 5,827 & 3,545 & 5,335 & 5,897 & NA & 2,847 \\
\hline U1417D-48X-1, 42-43 & 315.52 & 315.52 & 6,423 & 4,458 & 8,424 & 3,464 & 5,230 & 6,318 & NA & 2,685 \\
\hline U1417D-49X-3, 30-32 & 327.67 & 327.67 & 4,528 & 3,387 & 5,054 & 3,615 & 5,160 & 5,616 & NA & 2,394 \\
\hline U1417D-50X-1, 102-103 & 335.52 & 335.52 & 5,581 & 9,266 & 8,108 & 2,036 & 11,197 & 16,006 & 2,296 & 2,124 \\
\hline U1417D-50X-2, 102-103 & 336.89 & 336.89 & 4,528 & 3,436 & 4,844 & 2,882 & 3,580 & 4,001 & 2,538 & 3,145 \\
\hline U1417D-50X-2, 125-126 & 337.12 & 337.12 & 4,247 & 3,233 & 4,388 & 3,166 & 4,037 & 5,862 & NA & 2,296 \\
\hline U1417D-51X-1, 83-84 & 345.03 & 345.03 & 3,861 & 3,078 & 3,686 & 3,826 & 4,879 & 4,879 & 2,699 & 2,303 \\
\hline U1417D-51X-2, 57-58 & 346.27 & 346.27 & 5,090 & 3,686 & 5,090 & 3,650 & 5,335 & 5,370 & NA & 2,345 \\
\hline U1417D-51X-3, 16-17 & 346.77 & 346.77 & 6,143 & 5,405 & 5,651 & 3,352 & 5,441 & 6,318 & 2,819 & 2,601 \\
\hline U1417D-52X-1, 106-107 & 354.96 & 354.96 & 4,493 & 3,268 & 4,282 & 3,615 & 4,984 & 5,265 & 2,587 & 2,166 \\
\hline U1417D-52X-3, 98-99 & 357.58 & 357.58 & 4,984 & 3,615 & 5,265 & 3,580 & 5,125 & 5,019 & NA & 3,443 \\
\hline U1417D-53X-2, 36-37 & 364.97 & 364.97 & 5,230 & 3,966 & 6,739 & 3,580 & 4,949 & 5,019 & 2,780 & 3,356 \\
\hline U1417D-54X-3, 22-23 & 375.98 & 375.98 & 2,689 & 2,429 & 2,376 & 2,780 & 3,454 & 4,212 & 2,197 & 1,755 \\
\hline U1417D-54X-4, 66-67 & 377.90 & 377.90 & 5,160 & 3,756 & 6,880 & 3,454 & 5,019 & 5,967 & NA & 2,685 \\
\hline U1417D-55X-1, 58-59 & 383.58 & 383.58 & 5,581 & 3,966 & 7,792 & 3,468 & 5,125 & 6,213 & 2,984 & 2,710 \\
\hline U1417D-55X-3, 74-76 & 386.68 & 386.68 & 7,266 & 7,266 & 9,231 & 2,654 & 6,564 & 15,198 & 3,545 & 2,187 \\
\hline U1417D-55X-3, 119-120 & 387.13 & 387.13 & 6,739 & 5,370 & 8,880 & 3,236 & 5,827 & 7,336 & NA & 2,594 \\
\hline U1417D-56X-1, 69-70 & 393.39 & 393.39 & 5,265 & 3,931 & 5,967 & 2,797 & 6,985 & 6,669 & 2,566 & 2,341 \\
\hline U1417D-57X-1, 36-37 & 402.76 & 402.76 & 6,880 & 4,493 & 8,845 & 2,959 & 6,178 & 6,599 & 2,945 & 2,903 \\
\hline U1417D-58X-2, 80-81 & 414.39 & 412.74 & 3,826 & 2,439 & 4,001 & 3,292 & 4,247 & 4,072 & 2,274 & 1,923 \\
\hline U1417E-9R-1, 10-11 & 418.50 & 418.50 & 5,546 & 3,756 & 4,423 & 3,650 & 4,879 & 5,370 & NA & 2,647 \\
\hline U1417D-59X-1, 122-123 & 423.02 & 419.68 & 3,686 & 2,520 & 3,012 & 3,650 & 4,633 & 4,072 & NA & 1,902 \\
\hline U1417D-59X-3, 100-101 & 425.72 & 422.38 & 6,739 & 4,177 & 8,740 & 3,320 & 5,265 & 6,353 & 2,587 & 2,580 \\
\hline U1417E-9R-4, 136-137 & 424.26 & 424.26 & 5,686 & 4,037 & 7,862 & 3,040 & 6,072 & 6,880 & 2,576 & 2,573 \\
\hline U1417E-10R-1, 19-20 & 428.29 & 428.29 & 4,844 & 3,510 & 4,949 & 3,482 & 5,546 & 6,283 & 2,843 & 2,604 \\
\hline U1417E-10R-3, 19-21 & 431.29 & 431.29 & 8,389 & 3,166 & 7,792 & 2,727 & 7,617 & 7,090 & 2,636 & 2,190 \\
\hline U1417E-11R-1, 22-23 & 438.02 & 438.02 & 5,125 & NA & 6,283 & 3,177 & 11,864 & 9,372 & 2,594 & NA \\
\hline U1417E-11R-1, 116-117 & 438.96 & 438.96 & 4,037 & 2,685 & 4,949 & 2,910 & 8,740 & 9,126 & 2,418 & 1,881 \\
\hline U1417D-62X-CC, 26-27 & 442.21 & 442.21 & 4,423 & 2,510 & 6,037 & 2,822 & 9,512 & 8,810 & 2,622 & 1,769 \\
\hline U1417D-63X-CC, 18-20 & 447.23 & 447.23 & 6,178 & 3,791 & 8,740 & 3,415 & 5,335 & 6,353 & 3,064 & 2,566 \\
\hline U1417E-14R-1, 26-27 & 467.16 & 467.16 & 10,811 & 4,001 & 6,774 & 2,924 & 7,898 & 8,249 & 2,692 & 2,081 \\
\hline U1417E-14R-CC, 2-3 & 468.62 & 468.62 & 3,861 & 3,756 & 4,177 & 4,037 & 4,668 & 4,739 & 2,980 & 4,001 \\
\hline U1417E-15R-2, 69-70 & 478.79 & 478.79 & 6,388 & 3,791 & 7,476 & 3,650 & 5,511 & 6,107 & 3,064 & NA \\
\hline U1417E-16R-2, 66-67 & 488.09 & 488.09 & 12,355 & 3,324 & 6,037 & 2,250 & 9,442 & 13,303 & NA & 1,759 \\
\hline U1417E-17R-3, 97-98 & 499.83 & 499.83 & 5,686 & 3,173 & 5,405 & 2,475 & 8,073 & 6,774 & 2,503 & 2,134 \\
\hline U1417E-18R-3, 69-70 & 509.18 & 509.18 & 5,441 & 3,177 & 5,581 & 3,401 & 6,634 & 6,318 & 2,843 & 2,246 \\
\hline U1417E-19R-1, 65-66 & 516.05 & 516.05 & 5,721 & 2,826 & 5,090 & 2,594 & 7,968 & 6,880 & 1,945 & 2,106 \\
\hline U1417E-20R-2, 61-62 & 527.21 & 527.21 & 5,370 & 2,920 & 6,458 & 3,650 & 6,564 & 5,967 & 2,955 & 2,253 \\
\hline U1417E-21R-1, 37-38 & 535.17 & 534.80 & 5,300 & 3,001 & 5,019 & 2,559 & 9,758 & 7,547 & 2,443 & 2,573 \\
\hline U1417E-22R-1, 55-56 & 545.05 & 544.50 & 5,581 & 3,141 & 7,511 & 3,510 & 5,967 & 6,248 & NA & 2,453 \\
\hline U1417E-24R-1, 14-15 & 564.04 & 564.04 & 6,809 & 3,447 & 8,775 & 3,433 & 5,967 & 6,072 & 3,099 & 2,703 \\
\hline U1417E-24R-2, 11-12 & 565.00 & 565.00 & 9,266 & 3,292 & 7,055 & 2,769 & 8,600 & 10,004 & 2,555 & 2,415 \\
\hline U1417E-25R-1, 25-26 & 573.85 & 573.85 & 6,248 & 3,085 & 7,792 & 3,650 & 5,616 & 5,616 & 2,552 & 2,310 \\
\hline U1417E-25R-2, 29-30 & 575.31 & 575.31 & 5,405 & 3,187 & 7,266 & 3,650 & 5,827 & 5,827 & 3,064 & 2,548 \\
\hline U1417E-26R-1, 20-21 & 583.50 & 583.50 & 10,004 & 3,615 & 12,566 & 3,391 & 5,967 & 6,809 & NA & 2,489 \\
\hline U1417E-27R-4, 57-59 & 597.13 & 597.13 & 6,388 & 3,089 & 7,476 & 3,342 & 7,862 & 6,950 & 2,366 & 2,106 \\
\hline U1417E-28R-1, 52-54 & 603.22 & 603.22 & 5,932 & 3,208 & 6,002 & 3,931 & 5,511 & 5,616 & 2,776 & 2,436 \\
\hline U1417E-29R-2, 42-43 & 614.23 & 614.23 & 6,985 & 3,313 & 9,337 & 3,580 & 5,756 & 5,792 & NA & 2,745 \\
\hline U1417E-29R-3, 78-80 & 616.09 & 616.09 & 2,836 & 2,145 & 2,208 & 3,050 & 3,475 & 3,415 & 2,387 & 1,860 \\
\hline U1417E-29R-4, 90-91 & 617.64 & 617.64 & 11,618 & 4,493 & 6,318 & 2,668 & 8,354 & 13,022 & 2,461 & 2,095 \\
\hline U1417E-31R-1, 43-44 & 632.23 & 632.23 & 5,476 & 2,941 & 6,037 & 3,615 & 6,178 & 5,862 & 2,489 & 2,306 \\
\hline U1417E-31R-1, 53-54 & 632.33 & 632.33 & 6,529 & 2,955 & 7,441 & 3,208 & 6,704 & 6,704 & 2,299 & 2,141 \\
\hline U1417E-32R-1, 47-48 & 641.97 & 641.97 & 24,114 & 4,914 & 9,337 & 2,218 & 9,828 & 16,708 & NA & 1,860 \\
\hline U1417E-32R-2, 72-72 & 643.52 & 643.52 & 4,212 & 2,861 & 2,710 & 4,247 & 3,966 & 5,054 & 2,587 & NA \\
\hline U1417E-35R-1, 14-15 & 661.14 & 661.14 & 4,072 & 2,878 & 2,643 & 4,528 & 4,142 & 4,668 & 2,625 & 2,183 \\
\hline U1417E-35R-2, 51-53 & 662.97 & 662.97 & 17,164 & 4,247 & 11,829 & 2,706 & 9,021 & 14,777 & 2,706 & 2,253 \\
\hline U1417E-35R-3, 100-102 & 664.73 & 664.73 & 6,564 & 3,275 & 6,809 & 3,545 & 4,563 & 5,897 & 3,071 & 2,418 \\
\hline U1417E-37R-2, 39-40 & 682.31 & 682.31 & 13,759 & 3,187 & 6,318 & 2,566 & 8,459 & 9,231 & 2,552 & 2,415 \\
\hline U1417E-38R-1, 61-62 & 690.71 & 690.71 & 6,809 & 2,776 & 6,704 & 3,306 & 6,458 & 6,353 & 2,857 & 2,204 \\
\hline U1417E-38R-3, 6-8 & 693.16 & 693.16 & 11,794 & 2,931 & 6,458 & 2,822 & 7,090 & 7,687 & 2,861 & 2,274 \\
\hline U1417E-39R-1, 7-9 & 699.87 & 699.87 & 6,669 & 3,001 & 7,371 & 3,966 & 5,932 & 5,721 & NA & 2,394 \\
\hline U1417E-39R-1, 51-52 & 700.31 & 700.31 & 5,686 & 2,896 & 5,511 & 2,559 & 8,600 & 11,443 & 2,387 & 2,060 \\
\hline U1417E-39R-6, 96-98 & 706.62 & 706.62 & 4,107 & 2,668 & 2,899 & 3,931 & 4,528 & 4,247 & 2,583 & 1,990 \\
\hline
\end{tabular}

$\mathrm{NA}=$ not applicable. 
Table T5. Datum events for radiolarians, diatoms, and foraminifers, Site U1417.

\begin{tabular}{|c|c|c|c|c|c|c|c|c|c|c|c|c|c|}
\hline \multirow[b]{3}{*}{ Datum event } & \multirow{3}{*}{$\begin{array}{c}\text { Datum } \\
\text { type }\end{array}$} & \multirow{3}{*}{$\begin{array}{l}\text { Age } \\
\text { (Ma) }\end{array}$} & \multirow{2}{*}{\multicolumn{2}{|c|}{ Hole, core, section, interval $(\mathrm{cm})$}} & \multicolumn{3}{|c|}{ Depth CSF-A (m) } & \multicolumn{3}{|c|}{ Depth CCSF-A (m) } & \multicolumn{3}{|c|}{ Depth CCSF-B $(m)$} \\
\hline & & & & & \multirow{2}{*}{$\begin{array}{c}\text { Top } \\
\text { (middle) }\end{array}$} & \multirow{2}{*}{$\begin{array}{l}\text { Bottom } \\
\text { (middle) }\end{array}$} & \multirow[b]{2}{*}{ Median } & \multirow{2}{*}{$\begin{array}{c}\text { Top } \\
\text { (middle) }\end{array}$} & \multirow{2}{*}{$\begin{array}{l}\text { Bottom } \\
\text { (middle) }\end{array}$} & \multirow[b]{2}{*}{ Median } & \multirow{2}{*}{$\begin{array}{c}\text { Top } \\
\text { (middle) }\end{array}$} & \multirow{2}{*}{$\begin{array}{l}\text { Bottom } \\
\text { (middle) }\end{array}$} & \multirow[b]{2}{*}{ Median } \\
\hline & & & Top & Bottom & & & & & & & & & \\
\hline & & & $341-$ & $341-$ & & & & & & & & & \\
\hline LO Lychnocanoma nipponica sakaii & $\mathrm{R}$ & $0.03 \pm 0.03$ & U1417D-1H-CC & U1417B-2H-CC & 6.03 & 14.76 & 10.39 & 6.03 & 9.59 & 7.81 & 5.21 & 8.29 & 6.75 \\
\hline LO Proboscia curvirostris (D120) & D & $0.3 \pm 0.1$ & U1417B-6H-CC & U1417A-8H-CC & 49.02 & 56.89 & 52.95 & 57.17 & 61.32 & 59.24 & 49.45 & 53.04 & 51.24 \\
\hline LO Stylacontharium acquilonium & $\mathrm{R}$ & $0.4 \pm 0.1$ & U1417B-6H-CC & U1417B-7H-CC & 49.02 & 58.05 & 53.53 & 57.17 & 63.31 & 60.24 & 49.45 & 54.76 & 52.10 \\
\hline LO Stylatractus universus & $\mathrm{R}$ & $0.5 \pm 0.1$ & U1417B-7H-CC & U1417B-8H-CC & 58.05 & 67.06 & 62.55 & 63.31 & 73.55 & 68.43 & 54.76 & 63.62 & 59.19 \\
\hline LO Neogloloquadrina inglei & $\mathrm{F}$ & $0.7 \pm 0.1$ & U1417B-6H-CC & U1417B-10H-CC & 49.02 & 86.16 & 67.59 & 57.17 & 101.49 & 79.33 & 49.45 & 87.79 & 68.62 \\
\hline LO Actinocyclus oculatus (D110) & D & $1.1 \pm 0.1$ & U1417C-8H-CC & U1417D-9H-3, 80 & 65.41 & 69.80 & 67.60 & 76.46 & 80.30 & 78.38 & 66.13 & 69.46 & 67.80 \\
\hline LO Eucyrtidium matuyamai & $\mathrm{R}$ & $1.3 \pm 0.1$ & U1417D-16H-CC & U1417C-17H-CC & 138.26 & 151.24 & 144.75 & 157.94 & 174.70 & 166.32 & 136.61 & 151.11 & 143.86 \\
\hline FO Proboscia curvirostris (D105) & D & $1.8 \pm 0.1$ & U1417B-22H-3, 46 & U1417D-25H-CC & 181.58 & 185.36 & 183.47 & 210.25 & 210.90 & 210.57 & 181.72 & 182.20 & 181.96 \\
\hline FO Eucyrtidium matuyamai & $\mathrm{R}$ & $1.9 \pm 0.1$ & U1417B-27H-CC & U1417B-28H-CC & 202.54 & 207.29 & 204.91 & 235.31 & 244.99 & 240.15 & 200.24 & 207.40 & 203.82 \\
\hline LO Neodenticula koizumii (D100) & D & $2 \pm 0.4$ & U1417C-14H-CC & U1417D-15H-3, 130 & 122.64 & 123.60 & 123.12 & 140.93 & 141.18 & 141.05 & 121.90 & 122.12 & 122.01 \\
\hline FO Neodenticula seminae (D95) & $\mathrm{D}$ & $2.2 \pm$ undet. & U1417B-29H-CC & U1417C- $25 \mathrm{H}-\mathrm{CC}$ & 211.78 & 213.78 & 212.78 & 250.84 & 254.14 & 252.49 & 211.72 & 214.16 & 212.94 \\
\hline LO Neodenticula kamtschatica (D90) & D & $2.6 \pm 0.2$ & U1417D-48X-CC & U1417B-44X-CC & 317.74 & 324.05 & 320.89 & 361.00 & 370.73 & 365.86 & 317.74 & 327.47 & 322.60 \\
\hline FO Cycladophora davisiana & $\mathrm{R}$ & $2.8 \pm 0.1$ & U1417B-42X-CC & U1417B-43X-CC & 303.09 & 315.17 & 309.13 & 346.35 & 358.43 & 352.39 & 303.09 & 315.17 & 309.13 \\
\hline LO Stychocorys peregrina & $\mathrm{R}$ & $3.3 \pm 0.1$ & U1417D-47X-CC & U1417D-49X-CC & 307.84 & 328.42 & 318.13 & 351.10 & 371.68 & 361.39 & 307.84 & 328.42 & 318.13 \\
\hline FO Neodenticula koizumii (D80) & D & $3.75 \pm 0.35$ & U1417D-52X-CC & U1417D-53X-1, 69 & 357.89 & 364.29 & 361.09 & 401.15 & 407.55 & 404.35 & 357.89 & 364.29 & 361.09 \\
\hline LO Phormocyrtis fistula & $\mathrm{R}$ & $4.4 \pm 0.1$ & U1417D-56X-CC & U1417D-58X-CC & 394.44 & 416.10 & 405.27 & 437.70 & 457.72 & 447.71 & 394.44 & 414.46 & 404.45 \\
\hline LO Thalassionema schraderi & D & $7.9 \pm 0.4$ & U1417E-29R-4, 50 & U1417E-29R-5, 43 & 617.24 & 618.66 & 617.95 & 660.50 & 661.92 & 661.21 & 617.24 & 618.66 & 617.95 \\
\hline LO Cyrtocapsella japonica & $\mathrm{R}$ & $10 \pm 0.1$ & U1417E-29R-CC & U1417E-32R-CC & 619.07 & 645.12 & 632.09 & 662.33 & 688.38 & 675.35 & 619.07 & 645.12 & 632.09 \\
\hline
\end{tabular}

$\mathrm{LO}=$ last occurrence, $\mathrm{FO}=$ first occurrence. $\mathrm{R}=$ radiolarian, $\mathrm{D}=$ diatom, $\mathrm{F}=$ foraminifer. undet. $=$ undetermined.

Table T6. Diatoms, Site U1417. This table is available in an oversized format. 


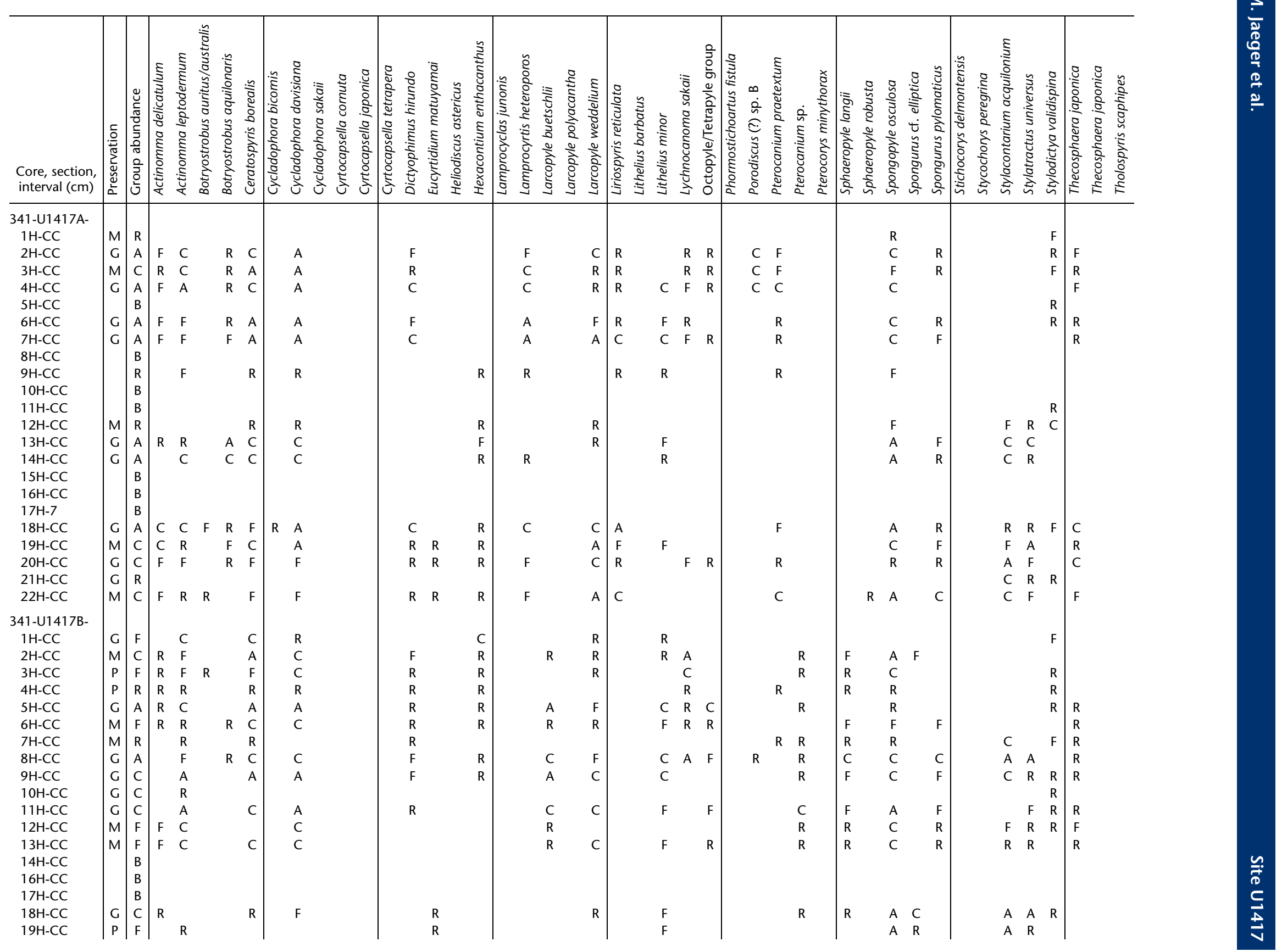




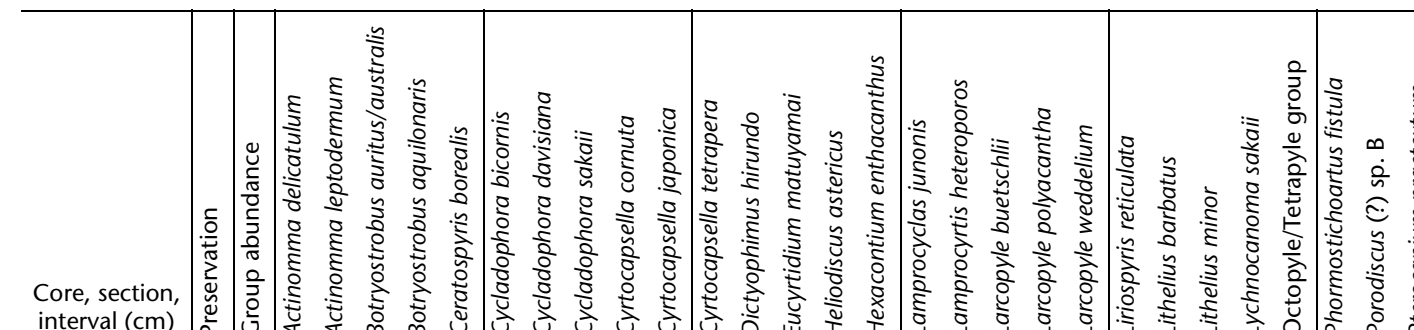

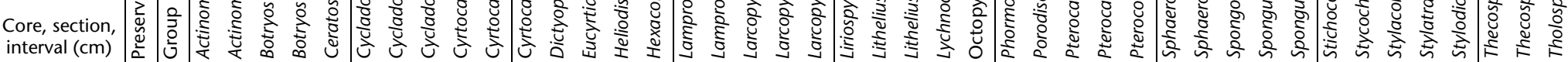

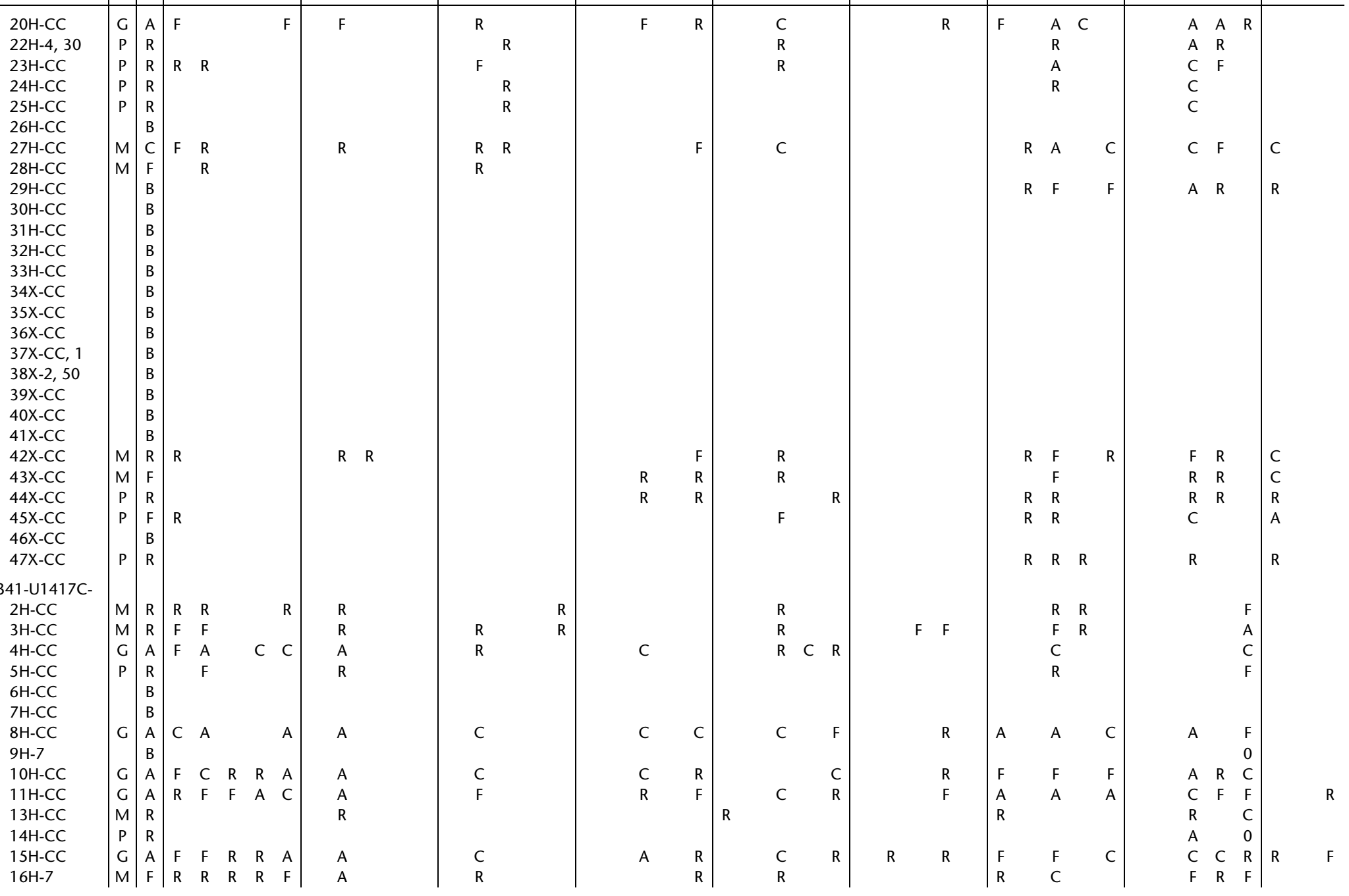

$16 \mathrm{H}-7$

\begin{tabular}{l|l|lllll|l|l} 
G & A & F & F & $R$ & $R$ & $A$ & $A$ \\
$M$ & F & R & $R$ & $R$ & $R$ & $F$ & A
\end{tabular}

$15 \mathrm{H}-\mathrm{CC}$
$16 \mathrm{H}-7$




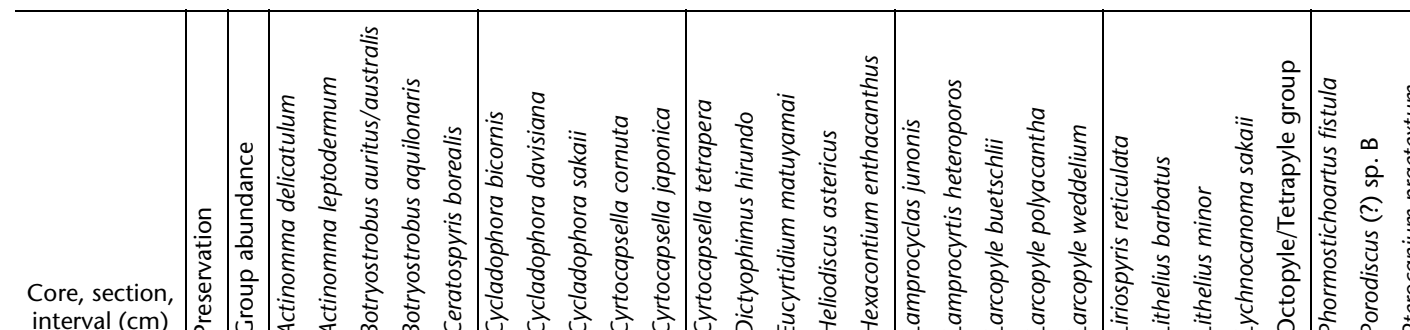

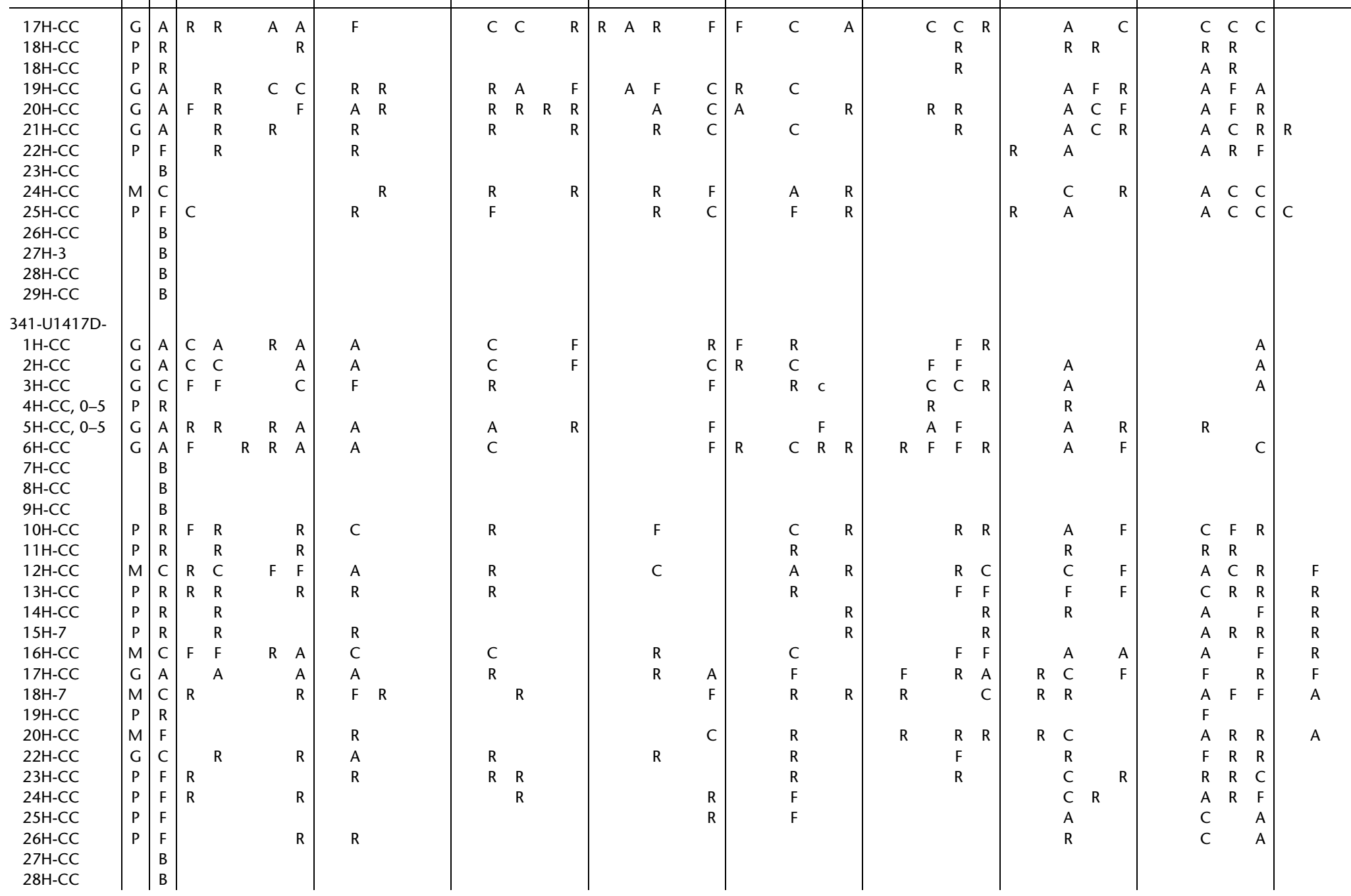

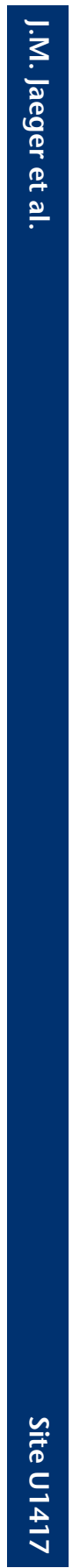




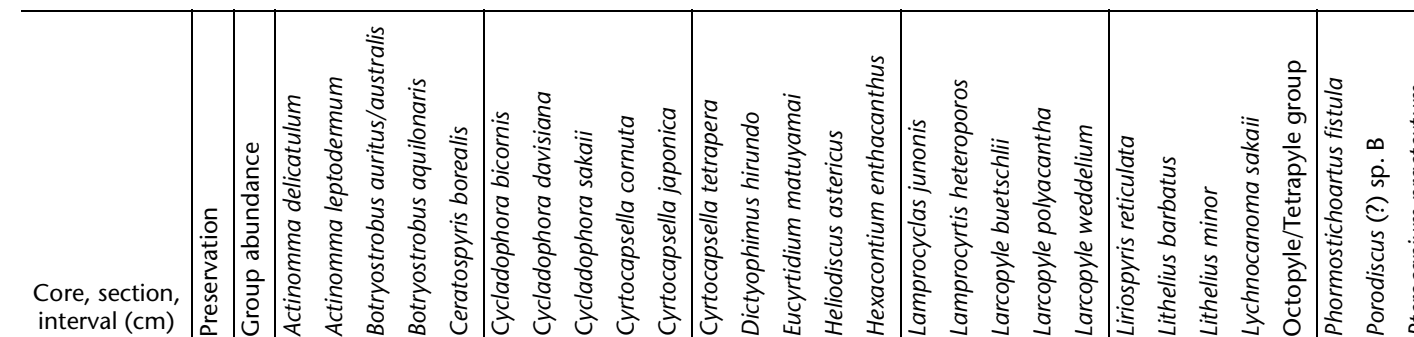

$32 \mathrm{H}-\mathrm{CC}$

\begin{tabular}{l|l|l|l} 
& $B$ & & \\
$P$ & $F$ & $R$
\end{tabular}

$33 \mathrm{H}-\mathrm{CC}$ \begin{tabular}{l|l|l}
$P$ & $R$ & $R$ \\
$P$ & $F$ &
\end{tabular}

$35 \mathrm{H}-\mathrm{CC}$

$36 \mathrm{H}-\mathrm{CC}$

$39 X-C C$

$40 \mathrm{X}-\mathrm{CC}$

$41 \mathrm{X}-\mathrm{CC}$

$42 X-C C$

$43 \mathrm{X}-\mathrm{CC}$
$44 \mathrm{X}-\mathrm{CC}$

$45 \mathrm{X}-\mathrm{CC}$

$45 X-C C$

$49 X-C C$
$50 X-C C$

$51 \mathrm{X}-\mathrm{CC}$

$52 \mathrm{X}-\mathrm{CC}$

$53 \mathrm{X}-\mathrm{CC}$

$54 X-C C$

$\begin{array}{ll}\mathrm{M} & \mathrm{F} \\ & \mathrm{B} \\ & \mathrm{B}\end{array}$

$55 \mathrm{X}-\mathrm{CC}$

$57 \mathrm{X}-\mathrm{CC}$

$58 \mathrm{X}-\mathrm{CC}$
$59 \mathrm{X}-\mathrm{CC}$

$60 \mathrm{X}-\mathrm{CC}$

$61 \mathrm{X}-\mathrm{CC}$

$62 \mathrm{X}-\mathrm{CC}$

$62 \mathrm{X}-\mathrm{CC}$

$63 \mathrm{X}-\mathrm{CC}$

$64 X-C C$

65X-CC

341-U1417E-

2R-CC

3R-CC

$\overrightarrow{\tilde{N}}$

$4 \mathrm{R}-\mathrm{CC}$

$5 R$

$\mathrm{R}$

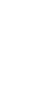

$B$

B
B
B
B
P
$F$

$\begin{array}{lll}P & B \\ P & R \\ P & R\end{array}$

\begin{tabular}{l|l|l|l|l}
$P$ & $R$ \\
$P$ & $R$
\end{tabular}

\begin{tabular}{l|l}
$P$ & $R$ \\
$P$ & $R$ \\
$P$ & $R$
\end{tabular}

\begin{tabular}{l|l}
$\mathrm{P}$ & $\mathrm{R}$ \\
$\mathrm{P}$ & $\mathrm{R}$ \\
& $\mathrm{B}$
\end{tabular}

M F

$\begin{array}{ll}\mathrm{P} & \mathrm{R} \\ & \mathrm{B}\end{array}$

M C $\mathrm{C}$

B

$P\left|\begin{array}{l}B \\ B \\ B \\ B \\ B \\ B \\ R \\ B \\ B \\ B \\ B\end{array}\right|$

R

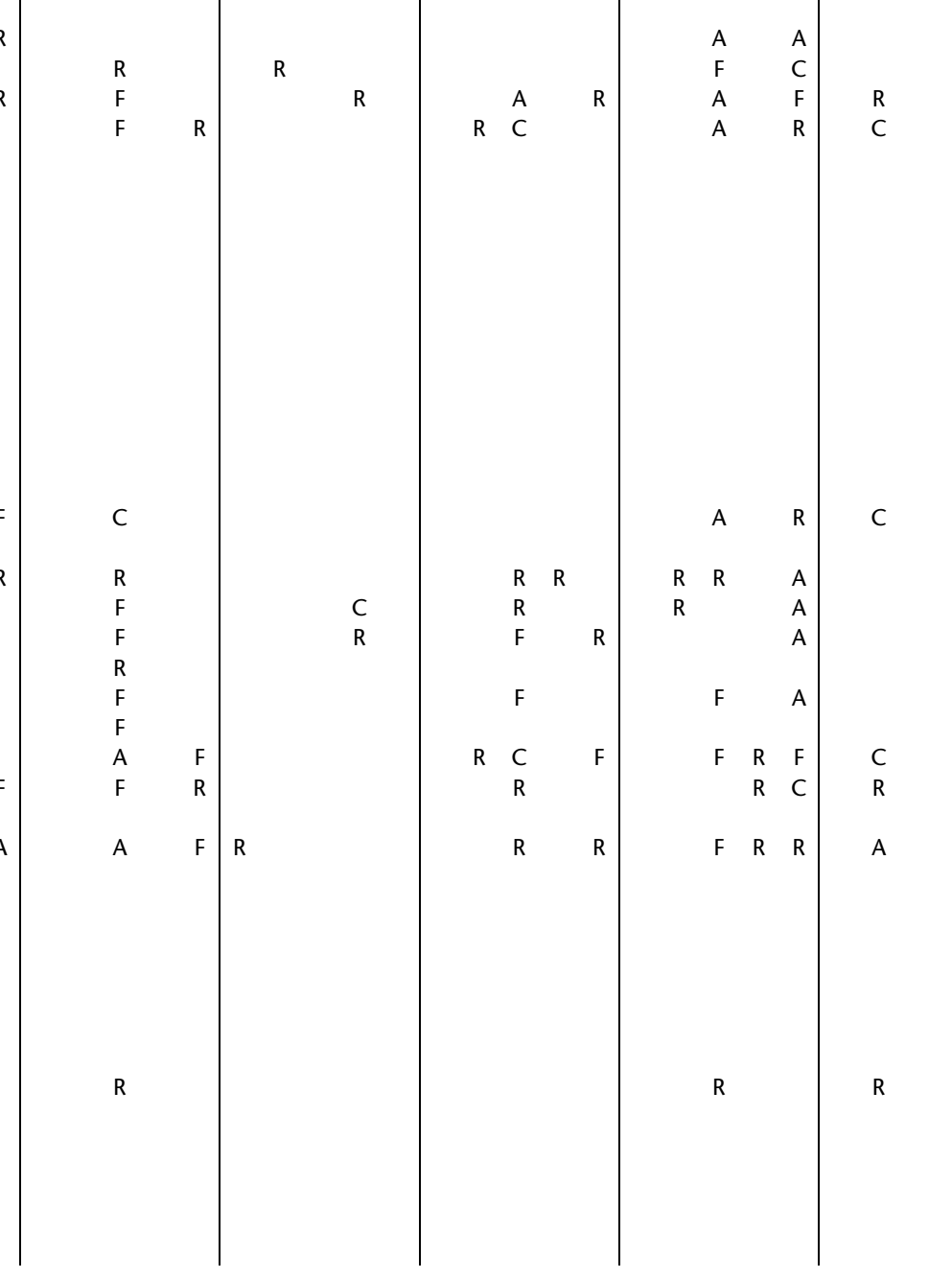




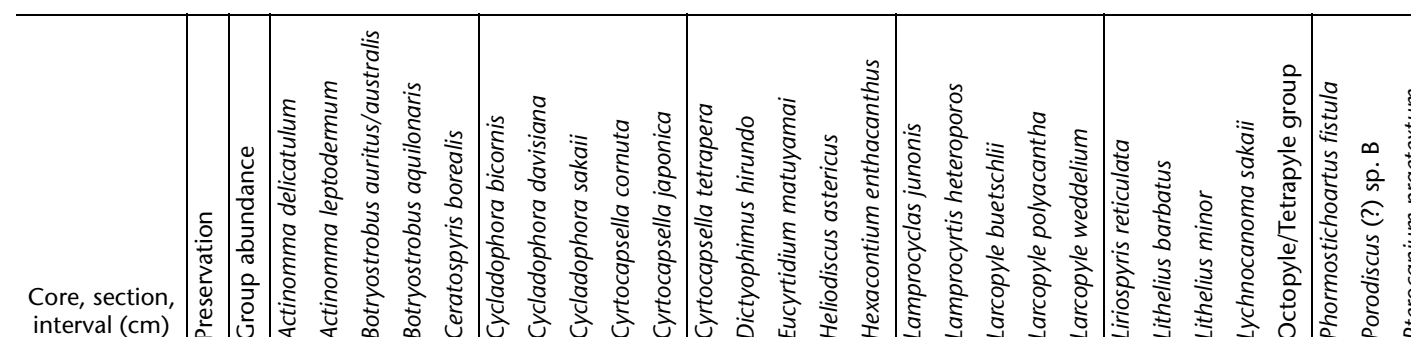

Core, section, interval

$7 \mathrm{R}-\mathrm{CC}$
$8 \mathrm{R}-\mathrm{CC}$

$8 \mathrm{R}-\mathrm{CC}$
9R-CC

10R-CC

$11 \mathrm{R}-\mathrm{CC}$

$12 \mathrm{R}-\mathrm{CC}$

23R-CC

$14 \mathrm{R}-\mathrm{CC}$

$15 \mathrm{R}-\mathrm{CC}$

16R-CC

$17 \mathrm{R}-\mathrm{CC}$

$18 \mathrm{R}-\mathrm{CC}$

19R-CC

20R-CC

$21 \mathrm{R}-\mathrm{CC}$

$22 \mathrm{R}-\mathrm{CC}$

$23 \mathrm{R}-\mathrm{CC}$

$24 \mathrm{R}-\mathrm{CC}$

$25 \mathrm{R}-\mathrm{CC}$

$27 R-C C$

28R-CC

$29 \mathrm{R}-\mathrm{CC}$

30R-CC

$31 \mathrm{R}-\mathrm{CC}$

$32 \mathrm{R}-\mathrm{CC}$

35R-CC

36R-CC

37R-CC

$38 \mathrm{R}-\mathrm{CC}$

$39 \mathrm{R}-\mathrm{CC}$

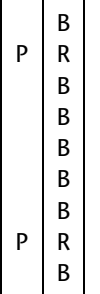

$B$
$B$
$B$
$B$
$B$

B

B
B
$B$
$B$

$B$
$B$
$B$

Preservation: $\mathrm{G}=$ good, $\mathrm{M}=$ moderate, $\mathrm{P}=$ poor. Abundance: $\mathrm{A}=$ abundant, $\mathrm{C}=$ common, $\mathrm{F}=\mathrm{few}, \mathrm{R}=$ Rare. This table is available in .CSV. 
Table T8. Planktonic foraminifers, Site U1417. (Continued on next page.)

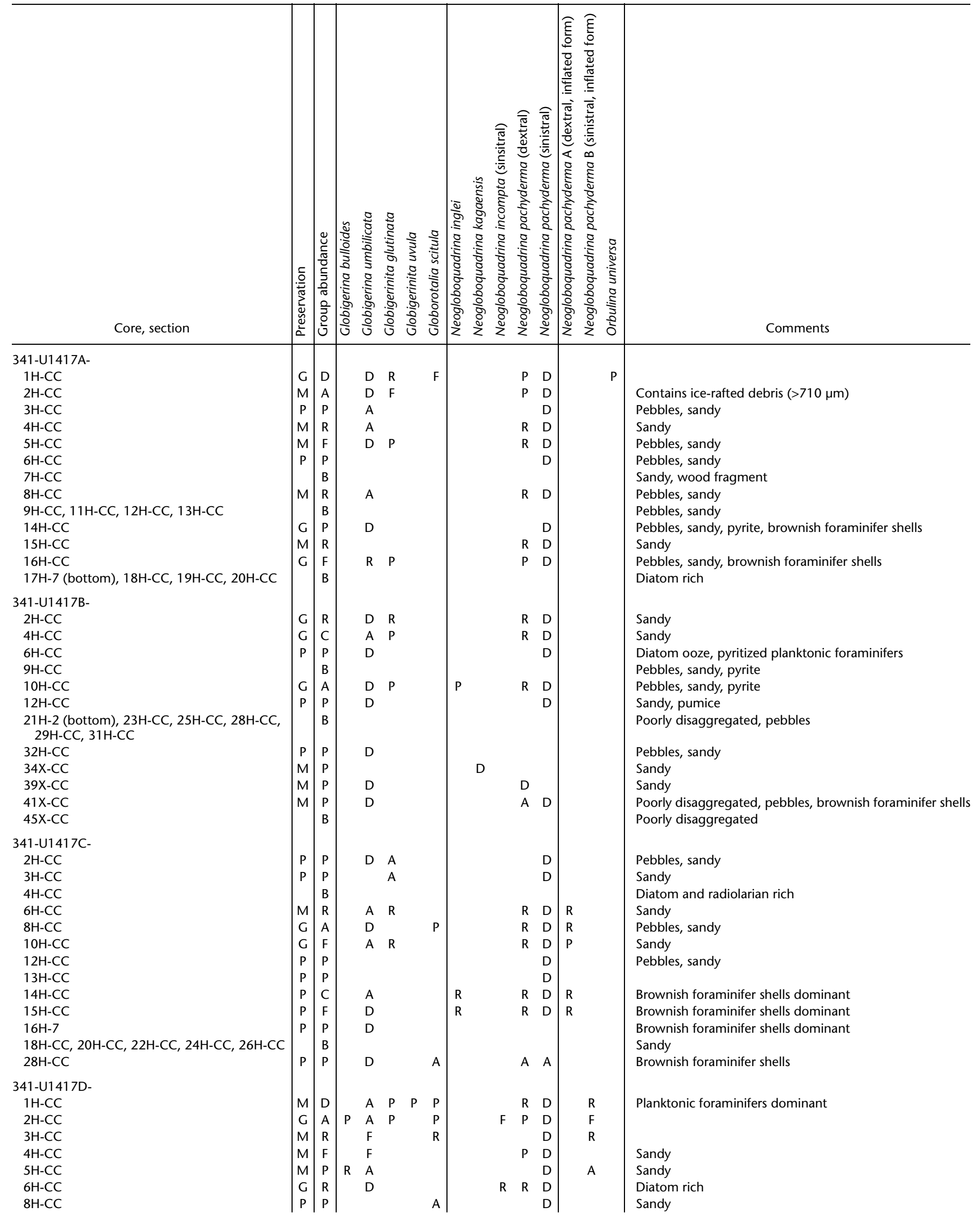


Table T8 (continued).

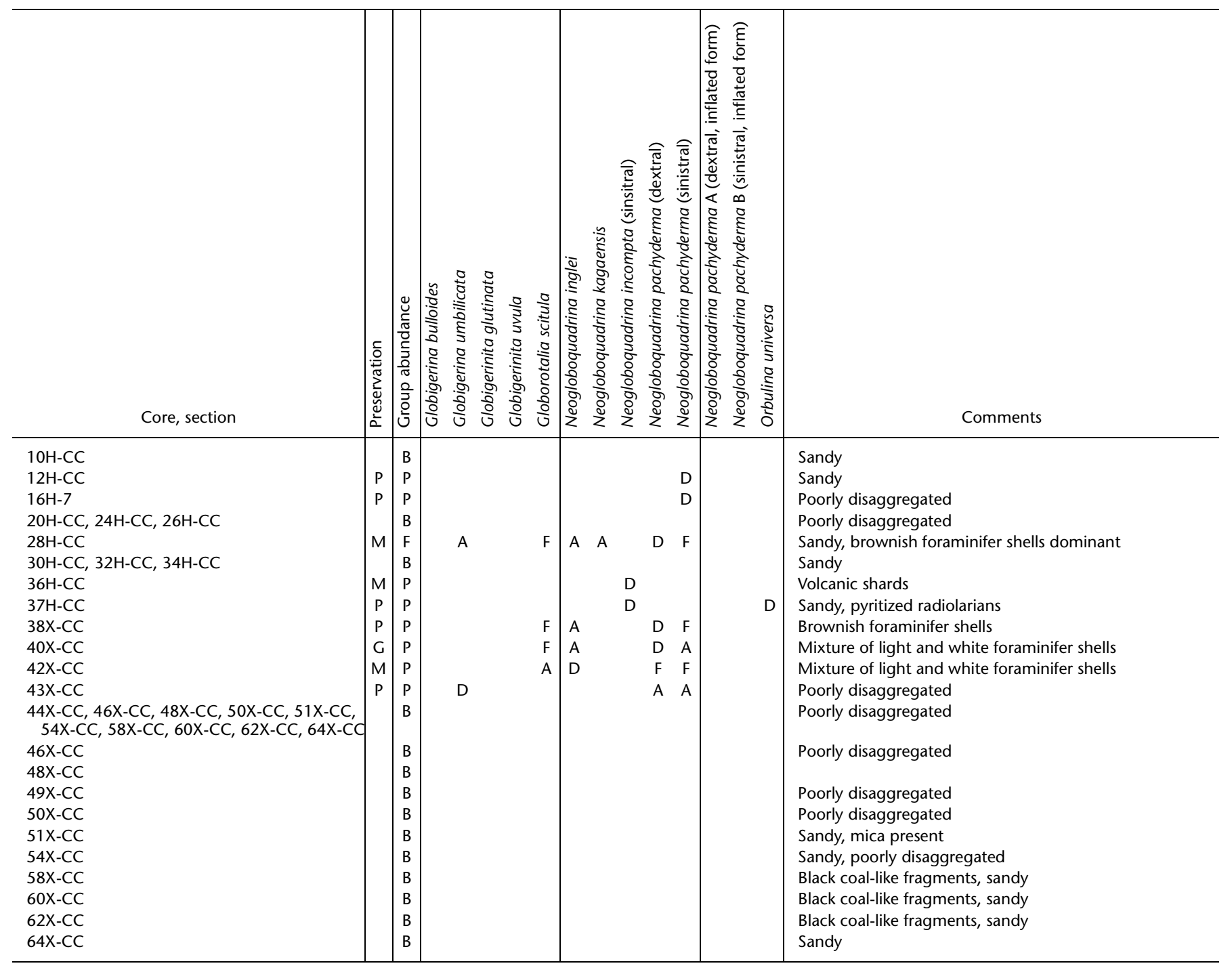

Preservation: $\mathrm{G}=$ good, $\mathrm{M}=$ moderate, $\mathrm{P}=$ poor. Abundance: $\mathrm{D}=$ dominant, $\mathrm{A}=$ abundant, $\mathrm{F}=\mathrm{few}, \mathrm{R}=\operatorname{rare}, \mathrm{P}=$ present, $\mathrm{B}=$ barren. This table is available in .CSV.

Table T9. Benthic foraminifers, Site U1417. This table is available in an oversized format. 
Table T10. Affine table, Site U1417.

\begin{tabular}{|c|c|c|c|c|c|c|c|}
\hline Core & Offset (m) & Core & Offset (m) & Core & Offset (m) & Core & Offset (m) \\
\hline 341-U1417A- & & $30 \mathrm{H}$ & 40.61 & $6 \mathrm{H}$ & 2.69 & $60 x$ & 43.26 \\
\hline $1 \mathrm{H}$ & 0.02 & $31 \mathrm{H}$ & 42.37 & $7 \mathrm{H}$ & 8.33 & $61 x$ & 43.26 \\
\hline $2 \mathrm{H}$ & 2.58 & $32 \mathrm{H}$ & 42.84 & $8 \mathrm{H}$ & 9.93 & $62 X$ & 43.26 \\
\hline $3 \mathrm{H}$ & 4.09 & $33 \mathrm{H}$ & 42.84 & $9 \mathrm{H}$ & 10.50 & $63 x$ & 43.26 \\
\hline $4 \mathrm{H}$ & 4.50 & $34 X$ & 43.26 & $10 \mathrm{H}$ & 11.61 & $64 X$ & 43.26 \\
\hline $5 \mathrm{H}$ & 5.11 & $35 x$ & 43.26 & $11 \mathrm{H}$ & 13.52 & $65 x$ & 43.26 \\
\hline $6 \mathrm{H}$ & 4.90 & $36 x$ & 43.26 & $12 \mathrm{H}$ & 14.14 & \multirow{2}{*}{\multicolumn{2}{|c|}{ 341-U1417E- }} \\
\hline 7H & 3.72 & $37 x$ & 43.26 & $13 \mathrm{H}$ & 14.84 & & \\
\hline $8 \mathrm{H}$ & 4.43 & $38 x$ & 43.26 & $14 \mathrm{H}$ & 16.52 & $3 R$ & 43.26 \\
\hline $9 \mathrm{H}$ & 8.46 & $39 x$ & 43.26 & $15 \mathrm{H}$ & 17.58 & $4 \mathrm{R}$ & 43.26 \\
\hline $10 \mathrm{H}$ & 9.40 & $40 x$ & 46.48 & $16 \mathrm{H}$ & 19.68 & $5 \mathrm{R}$ & 43.26 \\
\hline $11 \mathrm{H}$ & 13.04 & $41 x$ & 43.26 & $17 \mathrm{H}$ & 20.84 & 61 & No core recovery \\
\hline $12 \mathrm{H}$ & 14.82 & $42 x$ & 43.26 & $18 \mathrm{H}$ & 21.67 & $7 \mathrm{R}$ & 43.26 \\
\hline $13 \mathrm{H}$ & 16.49 & $43 x$ & 43.26 & $19 \mathrm{H}$ & Only $4 \%$ recovery & $8 \mathrm{R}$ & 43.26 \\
\hline $14 \mathrm{H}$ & 15.40 & $44 X$ & 46.68 & $20 \mathrm{H}$ & 25.34 & $9 \mathrm{R}$ & 43.26 \\
\hline $15 \mathrm{H}$ & 16.72 & $45 x$ & 43.26 & 211 & No core recovery & $10 \mathrm{R}$ & 43.26 \\
\hline $16 \mathrm{H}$ & 17.35 & $46 \mathrm{X}$ & 43.26 & $22 \mathrm{H}$ & 24.29 & $11 \mathrm{R}$ & 43.26 \\
\hline $17 \mathrm{H}$ & 17.33 & $47 X$ & 43.26 & $23 \mathrm{H}$ & 26.77 & $12 \mathrm{R}$ & 43.26 \\
\hline $18 \mathrm{H}$ & 17.74 & 341-U1417C- & & $24 \mathrm{H}$ & 25.90 & $13 R$ & 43.26 \\
\hline $19 \mathrm{H}$ & 20.21 & $2 \mathrm{H}$ & 2.30 & $25 \mathrm{H}$ & 25.54 & $14 \mathrm{R}$ & 43.26 \\
\hline $20 \mathrm{H}$ & 20.41 & $3 \mathrm{H}$ & 3.32 & $26 \mathrm{H}$ & 26.14 & $15 \mathrm{R}$ & 43.26 \\
\hline $21 \mathrm{H}$ & 24.01 & $4 \mathrm{H}$ & 3.59 & $27 \mathrm{H}$ & 28.88 & $16 \mathrm{R}$ & 43.26 \\
\hline $22 \mathrm{H}$ & 24.81 & $5 \mathrm{H}$ & 2.56 & $28 \mathrm{H}$ & 30.99 & $17 R$ & 43.26 \\
\hline 341-U1417B- & & $6 \mathrm{H}$ & 5.78 & $29 \mathrm{H}$ & 30.65 & $18 \mathrm{R}$ & 43.26 \\
\hline $1 \mathrm{H}$ & 0.01 & 7H & 6.51 & $30 \mathrm{H}$ & $\begin{array}{l}31.45 \\
3625\end{array}$ & $19 \mathrm{R}$ & 43.26 \\
\hline $2 \mathrm{H}$ & -5.17 & $8 \mathrm{H}$ & 11.05 & $31 \mathrm{H}$ & $\begin{array}{l}36.25 \\
3785\end{array}$ & $20 \mathrm{R}$ & 43.26 \\
\hline $3 \mathrm{H}$ & 4.79 & $9 \mathrm{H}$ & 11.91 & $32 \mathrm{H}$ & 37.85 & $21 \mathrm{R}$ & 43.26 \\
\hline $4 \mathrm{H}$ & 5.90 & $10 \mathrm{H}$ & 13.64 & $33 \mathrm{H}$ & 37.70 & $22 \mathrm{R}$ & 43.26 \\
\hline $5 \mathrm{H}$ & 7.93 & $\begin{array}{l}11 \mathrm{H} \\
12 \mathrm{H}\end{array}$ & 15.76 & $34 \mathrm{H}$ & $\begin{array}{l}38.48 \\
3960\end{array}$ & $23 \mathrm{R}$ & 43.26 \\
\hline $6 \mathrm{H}$ & 8.15 & $\begin{array}{l}12 \mathrm{H} \\
13 \mathrm{H}\end{array}$ & 17.46 & $35 \mathrm{H}$ & $\begin{array}{l}39.60 \\
40.31\end{array}$ & $24 \mathrm{R}$ & 43.26 \\
\hline 7H & 5.26 & $\begin{array}{l}13 \mathrm{H} \\
14 \mathrm{H}\end{array}$ & Only $1 \%$ recovery & $36 \mathrm{H}$ & $\begin{array}{l}40.31 \\
40.22\end{array}$ & $25 \mathrm{R}$ & 43.26 \\
\hline $8 \mathrm{H}$ & 6.49 & $\begin{array}{l}14 \mathrm{H} \\
15 \mathrm{H}\end{array}$ & 18.29 & $37 \mathrm{H}$ & $\begin{array}{l}40.22 \\
43.26\end{array}$ & $26 \mathrm{R}$ & 43.26 \\
\hline $9 \mathrm{H}$ & 12.98 & $\begin{array}{l}15 \mathrm{H} \\
16 \mathrm{H}\end{array}$ & 19.35 & $38 \mathrm{x}$ & $\begin{array}{l}43.26 \\
43.26\end{array}$ & $27 \mathrm{R}$ & 43.26 \\
\hline $10 \mathrm{H}$ & 15.33 & $\begin{array}{l}16 \mathrm{H} \\
17 \mathrm{H}\end{array}$ & 20.49 & $39 X$ & $\begin{array}{l}43.26 \\
46.48\end{array}$ & $28 \mathrm{R}$ & 43.26 \\
\hline $11 \mathrm{H}$ & 18.13 & $\begin{array}{l}17 \mathrm{H} \\
18 \mathrm{H}\end{array}$ & 23.46 & $\begin{array}{l}40 x \\
41 x\end{array}$ & $\begin{array}{l}46.48 \\
43.26\end{array}$ & $29 \mathrm{R}$ & 43.26 \\
\hline $12 \mathrm{H}$ & 19.34 & $\begin{array}{l}18 \mathrm{H} \\
19 \mathrm{H}\end{array}$ & 24.10 & $41 X$ & $\begin{array}{l}43.26 \\
43.26\end{array}$ & $30 \mathrm{R}$ & 43.26 \\
\hline $13 \mathrm{H}$ & $\begin{array}{l}21.36 \\
2298\end{array}$ & $\begin{array}{l}19 \mathrm{H} \\
20 \mathrm{H}\end{array}$ & 25.03 & $42 x$ & $\begin{array}{l}43.26 \\
43.26\end{array}$ & $31 R$ & 43.26 \\
\hline $14 \mathrm{H}$ & $\begin{array}{l}22.98 \\
\text { a }\end{array}$ & $\begin{array}{l}20 \mathrm{H} \\
21 \mathrm{H}\end{array}$ & 25.16 & $43 X$ & 43.26 & $32 \mathrm{R}$ & 43.26 \\
\hline $15 \mathrm{H}$ & No core recovery & $\begin{array}{l}21 \mathrm{H} \\
22 \mathrm{H}\end{array}$ & $\begin{array}{l}26.90 \\
28.03\end{array}$ & $\begin{array}{l}44 X \\
45 x\end{array}$ & 40.25 & $33 \mathrm{R}$ & No core recovery \\
\hline $16 \mathrm{H}$ & 23.96 & $\begin{array}{l}22 \mathrm{H} \\
23 \mathrm{H}\end{array}$ & 28.03 & $45 X$ & 40.92 & $34 \mathrm{R}$ & Only $2 \%$ recovery \\
\hline $17 \mathrm{H}$ & 23.61 & $\begin{array}{l}23 \mathrm{H} \\
24 \mathrm{H}\end{array}$ & 31.59 & $\begin{array}{l}46 X \\
47 X\end{array}$ & 43.26 & $35 \mathrm{R}$ & 43.26 \\
\hline $18 \mathrm{H}$ & 25.63 & $\begin{array}{l}24 \mathrm{H} \\
25 \mathrm{H}\end{array}$ & $\begin{array}{l}31.55 \\
40.36\end{array}$ & $\begin{array}{l}47 X \\
48 X\end{array}$ & 43.26 & $36 \mathrm{R}$ & 43.26 \\
\hline $19 \mathrm{H}$ & 25.44 & $\begin{array}{l}25 \mathrm{H} \\
26 \mathrm{H}\end{array}$ & $\begin{array}{l}40.36 \\
42.66\end{array}$ & $\begin{array}{l}48 X \\
49 X\end{array}$ & 43.26 & $37 R$ & 43.26 \\
\hline $20 \mathrm{H}$ & $\begin{array}{l}27.08 \\
26.90\end{array}$ & $27 \mathrm{H}$ & $\begin{array}{l}42.66 \\
40.93\end{array}$ & $\begin{array}{l}49 X \\
50 X\end{array}$ & 43.26 & $38 \mathrm{R}$ & 43.26 \\
\hline $21 \mathrm{H}$ & $\begin{array}{l}26.90 \\
28.67\end{array}$ & $28 \mathrm{H}$ & $\begin{array}{l}40.93 \\
41.29\end{array}$ & $\begin{array}{l}50 X \\
51 X\end{array}$ & 43.26 & $39 \mathrm{R}$ & 43.26 \\
\hline $\begin{array}{l}22 \mathrm{H} \\
23 \mathrm{H}\end{array}$ & $\begin{array}{l}28.67 \\
28.63\end{array}$ & $29 \mathrm{H}$ & 43.26 & $52 x$ & 43.26 & & \\
\hline $\begin{array}{l}23 \mathrm{H} \\
24 \mathrm{H}\end{array}$ & $\begin{array}{l}28.63 \\
32.09\end{array}$ & 341-U1417D- & & $53 x$ & 43.26 & \multirow{6}{*}{\multicolumn{2}{|c|}{$\begin{array}{l}\text { Core: } \mathrm{H}=\text { advanced piston } \\
\text { corer, } \mathrm{X}=\text { extended core barrel, } \\
\mathrm{R}=\text { rotary core barrel. Cores } \\
\text { with very low recovery were } \\
\text { not used for correlation pur- } \\
\text { poses. }\end{array}$}} \\
\hline $25 \mathrm{H}$ & 33.39 & $1 \mathrm{H}$ & 0.00 & $54 \mathrm{X}$ & 43.26 & & \\
\hline $26 \mathrm{H}$ & 32.68 & $2 \mathrm{H}$ & 0.80 & $55 x$ & 43.26 & & \\
\hline $27 \mathrm{H}$ & 32.77 & $3 \mathrm{H}$ & 2.13 & $56 \mathrm{X}$ & 43.26 & & \\
\hline $28 \mathrm{H}$ & 37.70 & $4 \mathrm{H}$ & 3.26 & $57 X$ & 43.26 & & \\
\hline $29 \mathrm{H}$ & 39.06 & $5 \mathrm{H}$ & 1.84 & $\begin{array}{l}58 X \\
59 X\end{array}$ & $\begin{array}{l}41.62 \\
39.91\end{array}$ & & \\
\hline
\end{tabular}


Table T11. Splice tie points, Site U1417.

\begin{tabular}{|c|c|c|c|c|c|c|c|c|}
\hline $\begin{array}{c}\text { Hole, } \\
\text { core, section }\end{array}$ & $\begin{array}{l}\text { Tie point } \\
(\mathrm{cm})\end{array}$ & $\begin{array}{c}\text { Depth } \\
\text { CSF-A } \\
(\mathrm{m})\end{array}$ & $\begin{array}{l}\text { Depth } \\
\text { CCSF-A } \\
(\mathrm{m})\end{array}$ & Tie/Append & $\begin{array}{c}\text { Hole, } \\
\text { core, section }\end{array}$ & $\begin{array}{l}\text { Tie point } \\
\text { (cm) }\end{array}$ & $\begin{array}{c}\text { Depth } \\
\text { CSF-A } \\
\text { (m) }\end{array}$ & $\begin{array}{l}\text { Depth } \\
\text { CCSF-A } \\
\text { (m) }\end{array}$ \\
\hline $341-$ & & & & & 341- & & & \\
\hline U1417D-1H-4 & 55.01 & 5.05 & 5.05 & Tie to & U1417C-2H-2 & 25.13 & 2.75 & 5.05 \\
\hline U1417C-2H-5 & 78.14 & 7.78 & 10.08 & Tie to & U1417D-2H-3 & 27.80 & 9.28 & 10.08 \\
\hline U1417D-2H-6 & 93.77 & 14.16 & 14.96 & Tie to & U1417C-3H-1 & 114.24 & 11.64 & 14.96 \\
\hline U1417C-3H-4 & 133.20 & 16.33 & 19.65 & Tie to & U1417D-3H-2 & 52.39 & 17.52 & 19.65 \\
\hline U1417D-3H-6 & 56.21 & 23.02 & 25.15 & Tie to & U1417C-4H-2 & 6.09 & 21.56 & 25.15 \\
\hline U1417C-4H-5 & 34.90 & 26.35 & 29.94 & Tie to & U1417D-4H-2 & 17.25 & 26.67 & 29.94 \\
\hline U1417D-4H-4 & 83.81 & 30.34 & 33.60 & Tie to & U1417C-5H-2 & 4.18 & 31.04 & 33.60 \\
\hline U1417C-5H-6 & 73.25 & 37.73 & 40.29 & Tie to & U1417D-5H-3 & 95.09 & 38.45 & 40.29 \\
\hline U1417D-5H-6 & 123.90 & 43.24 & 45.08 & Tie to & U1417C-6H-2 & 80.31 & 39.30 & 45.08 \\
\hline U1417C-6H-5 & 44.97 & 43.45 & 49.23 & Tie to & U1417D-6H-2 & 103.66 & 46.54 & 49.23 \\
\hline U1417D-6H-6 & 56.81 & 52.07 & 54.76 & Tie to & U1417C-7H-2 & 24.60 & 48.25 & 54.76 \\
\hline U1417C-7H-7 & 16.86 & 55.67 & 62.18 & Tie to & U1417D-7H-1 & 34.84 & 53.85 & 62.18 \\
\hline U1417D-7H-3 & 126.59 & 57.77 & 66.10 & Tie to & U1417A-9H-1 & 73.71 & 57.64 & 66.10 \\
\hline U1417A-9H-3 & 26.98 & 60.17 & 68.63 & Tie to & U1417C-8H-2 & 7.96 & 57.58 & 68.63 \\
\hline U1417C-8H-7 & 57.10 & 65.07 & 76.12 & Tie to & U1417A-10H-1 & 32.74 & 66.73 & 76.12 \\
\hline U1417A-10H-2 & 103.70 & 68.94 & 78.33 & Tie to & U1417D-9H-2 & 33.13 & 67.83 & 78.33 \\
\hline U1417D-9H-5 & 59.64 & 72.60 & 83.10 & Tie to & U1417B-9H-3 & 1.79 & 70.12 & 83.10 \\
\hline U1417B-9H-6 & 108.50 & 75.68 & 88.66 & Tie to & U1417D-10H-2 & 5.11 & 77.05 & 88.66 \\
\hline U1417D-10H-6 & 110.52 & 84.12 & 95.73 & Tie to & U1417B-10H-3 & 79.94 & 80.40 & 95.73 \\
\hline U1417B-10H-6 & 87.13 & 84.98 & 100.31 & Tie to & U1417D-11H-2 & 29.14 & 86.79 & 100.31 \\
\hline U1417D-11H-6 & 22.10 & 92.22 & 105.74 & Tie to & U1417B-11H-2 & 1.20 & 87.61 & 105.74 \\
\hline U1417B-11H-6 & 32.36 & 93.92 & 112.05 & Tie to & U1417C-12H-1 & 59.33 & 94.59 & 112.05 \\
\hline U1417C-12H-5 & 109.96 & 101.10 & 118.56 & Tie to & U1417D-13H-2 & 41.74 & 103.72 & 118.56 \\
\hline U1417D-13H-6 & 30.52 & 109.61 & 124.45 & Tie to & U1417A-14H-4 & 14.19 & 109.04 & 124.45 \\
\hline U1417A-14H-6 & 94.49 & 112.84 & 128.25 & Tie to & U1417D-14H-2 & 42.72 & 111.73 & 128.25 \\
\hline U1417D-14H-5 & 128.80 & 117.09 & 133.61 & Tie to & U1417C-14H-2 & 81.77 & 115.32 & 133.61 \\
\hline U1417C-14H-6 & 131.03 & 121.81 & 140.10 & Tie to & U1417D-15H-3 & 22.60 & 122.53 & 140.10 \\
\hline U1417D-15H-6 & 113.27 & 127.93 & 145.51 & Tie to & U1417C-15H-3 & 65.55 & 126.16 & 145.51 \\
\hline U1417C-15H-6 & 140.17 & 131.40 & 150.75 & Tie to & U1417D-16H-2 & 77.63 & 131.08 & 150.75 \\
\hline U1417D-16H-6 & 100.77 & 137.31 & 156.99 & Tie to & $\mathrm{U} 1417 \mathrm{C}-16 \mathrm{H}-3$ & 149.81 & 136.50 & 156.99 \\
\hline U1417C-16H-6 & 73.23 & 140.23 & 160.72 & Tie to & U1417D-17H-2 & 8.07 & 139.88 & 160.72 \\
\hline U1417D-17H-5 & 139.97 & 145.70 & 166.54 & Tie to & $\mathrm{U} 1417 \mathrm{C}-17 \mathrm{H}-2$ & 7.58 & 143.08 & 166.54 \\
\hline U1417C-17H-5 & 127.57 & 148.78 & 172.24 & Tie to & U1417D-18H-3 & 17.29 & 150.57 & 172.24 \\
\hline U1417D-18H-6 & 123.99 & 156.14 & 177.81 & Tie to & U1417C-18H-2 & 120.88 & 153.71 & 177.81 \\
\hline U1417C-18H-3 & 103.75 & 155.04 & 179.14 & Tie to & U1417B-18H-1 & 90.79 & 153.51 & 179.14 \\
\hline U1417B-18H-5 & 77.27 & 159.37 & 185.00 & Tie to & U1417A-21H-2 & 109.36 & 160.99 & 185.00 \\
\hline U1417A-21H-3 & 135.07 & 162.75 & 186.76 & Tie to & U1417B-19H-1 & 12.14 & 161.32 & 186.76 \\
\hline U1417B-19H-4 & 111.97 & 166.82 & 192.26 & Tie to & $\mathrm{U} 1417 \mathrm{C}-20 \mathrm{H}-2$ & 149.74 & 167.10 & 192.26 \\
\hline U1417C-20H-5 & 100.65 & 171.11 & 196.26 & Tie to & U1417B-20H-2 & 80.73 & 169.19 & 196.26 \\
\hline U1417B-20H-7 & 38.01 & 176.06 & 203.14 & Tie to & U1417D-24H-2 & 3.57 & 177.24 & 203.14 \\
\hline U1417D-24H-3 & 47.73 & 179.18 & 205.08 & Tie to & U1417C-21H-4 & 7.77 & 178.18 & 205.08 \\
\hline U1417C-21H-4 & 145.23 & 179.55 & 206.45 & Tie to & U1417D-25H-1 & 51.17 & 180.91 & 206.45 \\
\hline U1417D-25H-3 & 106.26 & 184.46 & 210.00 & Tie to & U1417B-22H-3 & 21.32 & 181.33 & 210.00 \\
\hline U1417B-22H-4 & 47.19 & 182.62 & 211.29 & Tie to & U1417C-22H-1 & 16.37 & 183.26 & 211.29 \\
\hline U1417C-22H-7 & 54.03 & 192.34 & 220.37 & Tie to & U1417B-24H-1 & 77.58 & 188.28 & 220.37 \\
\hline U1417B-24H-1 & 77.58 & 188.28 & 220.37 & Append & U1417B-24H-4 & 54.00 & 192.09 & 224.18 \\
\hline
\end{tabular}

Tie points in bold reflect tentative correlations. See text for details. 
Table T12. Polarity chronozone interpretations, Site U1417.

\begin{tabular}{lllll}
\hline \multicolumn{1}{c}{ Polarity zone interpretation } & $\begin{array}{c}\text { Age } \\
(\mathrm{Ma})\end{array}$ & $\pm(\mathrm{Ma})$ & $\begin{array}{c}\text { Depth } \\
\text { CCSF-B (m) }\end{array}$ & $\pm(\mathrm{m})$ \\
\hline C1n (B) Matuyama/Brunhes & 0.781 & 0.02 & 111 & 1 \\
C1r.1n (T) Jaramillo & 0.988 & 0.02 & 133 & 1.5 \\
C1r.1n (B) Jaramillo & 1.072 & 0.02 & 140 & 1 \\
C1r.2n (M) Cobb Mountain & 1.179 & 0.02 & 150.5 & 1.5 \\
C2n (T) Olduvai & 1.778 & 0.02 & 186 & 2 \\
C2n (B) Olduvai & 1.945 & 0.02 & 205.5 & 1 \\
C2r.1n (T) Reunion & 2.128 & 0.02 & 220.5 & 2 \\
C2r.1n (B) Reunion & 2.148 & 0.02 & 224.5 & 4 \\
C2r.2r (B) Gauss/Matuyama & 2.581 & 0.02 & 287.5 & 1 \\
C2An.3n (B) Gilbert/Gauss & 3.596 & 0.02 & 365 & 5 \\
C3n.1n (T) Cochiti & 4.187 & 0.02 & 375 & 5 \\
Middle of C3n.3n (B) Sidufjal to C3n.4n (B) Thvera & 5.017 & 0.218 & 419 & 5 \\
C3An.1n (T) & 6.033 & 0.1 & 475 & 10 \\
C3Bn (T) & 7.14 & 0.1 & 585 & 20 \\
\hline
\end{tabular}

$B=$ bottom,$T=$ top,$M=$ middle

Table T13. Shipboard age-depth models and sedimentation rates, Site U1417.

\begin{tabular}{|c|c|c|c|c|c|c|c|c|c|}
\hline $\begin{array}{l}\text { Age } \\
\text { (Ma) }\end{array}$ & $\begin{array}{l}\text { Average } \\
\text { depth } \\
\text { CCSF-A } \\
(\mathrm{m})\end{array}$ & $\begin{array}{l}\text { Minimum } \\
\text { depth } \\
\text { CCSF-A } \\
\text { (m) }\end{array}$ & $\begin{array}{l}\text { Maximum } \\
\text { depth } \\
\text { CCSF-A } \\
\text { (m) }\end{array}$ & $\begin{array}{l}\text { Average } \\
\text { depth } \\
\text { CCSF-B } \\
\text { (m) }\end{array}$ & $\begin{array}{l}\text { Minimum } \\
\text { depth } \\
\text { CCSF-B } \\
\text { (m) }\end{array}$ & $\begin{array}{l}\text { Maximum } \\
\text { depth } \\
\text { CCSF-B } \\
\text { (m) }\end{array}$ & $\begin{array}{l}\text { Average } \\
\text { sed. rate } \\
(\mathrm{m} / \mathrm{m} . \mathrm{y} .)\end{array}$ & $\begin{array}{l}\text { Minimum } \\
\text { sed. rate } \\
\text { (m/m.y.) }\end{array}$ & $\begin{array}{c}\text { Maximum } \\
\text { sed. rate } \\
\text { (m/m.y.) }\end{array}$ \\
\hline 0.0 & 0.00 & 0.00 & 0.00 & 0.0 & 0.0 & 0.0 & 135.0 & 118.4 & 153.0 \\
\hline 0.5 & 78.03 & 57.80 & 98.27 & 67.5 & 50.0 & 85.0 & 135.0 & 118.4 & 153.0 \\
\hline 0.5 & 78.03 & 57.80 & 98.27 & 67.5 & 50.0 & 85.0 & 130.0 & 110.3 & 148.2 \\
\hline 1.0 & 153.18 & 144.51 & 161.85 & 132.5 & 125.0 & 140.0 & 130.0 & 110.3 & 148.2 \\
\hline 1.0 & 153.18 & 144.51 & 161.85 & 132.5 & 125.0 & 140.0 & 75.0 & 61.2 & 88.5 \\
\hline 1.5 & 196.53 & 184.97 & 208.09 & 170.0 & 160.0 & 180.0 & 75.0 & 61.2 & 88.5 \\
\hline 1.5 & 196.53 & 184.97 & 208.09 & 170.0 & 160.0 & 180.0 & 75.0 & 63.2 & 86.4 \\
\hline 2.0 & 245.12 & 234.97 & 255.27 & 207.5 & 200.0 & 215.0 & 75.0 & 63.2 & 86.4 \\
\hline 2.0 & 245.12 & 234.97 & 255.27 & 207.5 & 200.0 & 215.0 & 145.0 & 134.2 & 156.9 \\
\hline 2.5 & 323.26 & 313.26 & 333.26 & 280.0 & 270.0 & 290.0 & 145.0 & 134.2 & 156.9 \\
\hline 2.5 & 323.26 & 313.26 & 333.26 & 280.0 & 270.0 & 290.0 & 85.0 & 67.1 & 106.0 \\
\hline 3.0 & 365.76 & 348.26 & 383.26 & 322.5 & 305.0 & 340.0 & 85.0 & 67.1 & 106.0 \\
\hline 3.0 & 365.76 & 348.26 & 383.26 & 322.5 & 305.0 & 340.0 & 65.0 & 42.3 & 88.0 \\
\hline 3.5 & 398.26 & 383.26 & 413.26 & 355.0 & 340.0 & 370.0 & 65.0 & 42.3 & 88.0 \\
\hline 3.5 & 398.26 & 383.26 & 413.26 & 355.0 & 340.0 & 370.0 & 40.0 & 18.3 & 58.9 \\
\hline 4.0 & 418.26 & 403.26 & 433.26 & 375.0 & 360.0 & 390.0 & 40.0 & 18.3 & 58.9 \\
\hline 4.0 & 418.26 & 403.26 & 433.26 & 375.0 & 360.0 & 390.0 & 40.0 & 20.1 & 60.6 \\
\hline 4.5 & 438.26 & 423.26 & 453.26 & 395.0 & 380.0 & 410.0 & 40.0 & 20.1 & 60.6 \\
\hline 4.5 & 438.26 & 423.26 & 453.26 & 395.0 & 380.0 & 410.0 & 45.0 & 23.5 & 66.9 \\
\hline 5.0 & 460.76 & 448.26 & 473.26 & 417.5 & 405.0 & 430.0 & 45.0 & 23.5 & 66.9 \\
\hline 5.0 & 460.76 & 448.26 & 473.26 & 417.5 & 405.0 & 430.0 & 55.0 & 34.5 & 72.5 \\
\hline 5.5 & 488.26 & 473.26 & 503.26 & 445.0 & 430.0 & 460.0 & 55.0 & 34.5 & 72.5 \\
\hline 5.5 & 488.26 & 473.26 & 503.26 & 445.0 & 430.0 & 460.0 & 55.0 & 35.6 & 74.3 \\
\hline 6.0 & 515.76 & 503.26 & 528.26 & 472.5 & 460.0 & 485.0 & 55.0 & 35.6 & 74.3 \\
\hline 6.0 & 515.76 & 503.26 & 528.26 & 472.5 & 460.0 & 485.0 & 110.0 & 68.9 & 149.2 \\
\hline 6.5 & 570.76 & 533.26 & 608.26 & 527.5 & 490.0 & 565.0 & 110.0 & 68.9 & 149.2 \\
\hline 6.5 & 570.76 & 533.26 & 608.26 & 527.5 & 490.0 & 565.0 & 95.0 & 44.4 & 140.2 \\
\hline 7.0 & 618.26 & 593.26 & 643.26 & 575.0 & 550.0 & 600.0 & 95.0 & 44.4 & 140.2 \\
\hline 7.0 & 618.26 & 593.26 & 643.26 & 575.0 & 550.0 & 600.0 & 60.0 & 32.9 & 92.1 \\
\hline 7.5 & 648.26 & 633.26 & 663.26 & 605.0 & 590.0 & 620.0 & 60.0 & 32.9 & 92.1 \\
\hline 7.5 & 648.26 & 633.26 & 663.26 & 605.0 & 590.0 & 620.0 & 20.0 & 1.0 & 40.1 \\
\hline 8.0 & 658.26 & 648.26 & 668.26 & 615.0 & 605.0 & 625.0 & 20.0 & 1.0 & 40.1 \\
\hline 8.0 & 658.26 & 648.26 & 668.26 & 615.0 & 605.0 & 625.0 & 10.0 & 0.0 & 25.1 \\
\hline 8.5 & 663.26 & 653.26 & 673.26 & 620.0 & 610.0 & 630.0 & 10.0 & 0.0 & 25.1 \\
\hline 8.5 & 663.26 & 653.26 & 673.26 & 620.0 & 610.0 & 630.0 & 10.0 & 0.0 & 24.7 \\
\hline 9.0 & 668.26 & 658.26 & 678.26 & 625.0 & 615.0 & 635.0 & 10.0 & 0.0 & 24.7 \\
\hline 9.0 & 668.26 & 658.26 & 678.26 & 625.0 & 615.0 & 635.0 & 10.0 & 0.0 & 23.2 \\
\hline 9.5 & 673.26 & 663.26 & 683.26 & 630.0 & 620.0 & 640.0 & 10.0 & 0.0 & 23.2 \\
\hline 9.5 & 673.26 & 663.26 & 683.26 & 630.0 & 620.0 & 640.0 & 10.0 & 0.0 & 23.6 \\
\hline 10.0 & 678.26 & 668.26 & 688.26 & 635.0 & 625.0 & 645.0 & 10.0 & 0.0 & 23.6 \\
\hline 10.0 & 678.26 & 668.26 & 688.26 & 635.0 & 625.0 & 645.0 & 5.5 & 5.3 & 5.7 \\
\hline 39.0 & 838.26 & 830.26 & 846.26 & 795.0 & 787.0 & 803.0 & 5.5 & 5.3 & 5.7 \\
\hline
\end{tabular}


Table T14. Alternating field (AF) demagnetization steps used, Site U1417.

\begin{tabular}{|c|c|c|}
\hline Hole & Cores undertaken & $\begin{array}{l}\text { AF demagnetization } \\
\text { steps (mT) }\end{array}$ \\
\hline U1417A & $1 \mathrm{H}, 2 \mathrm{H}, 3 \mathrm{H}, 4 \mathrm{H}$ & $0,5,10,15,20$ \\
\hline U1417A & All other cores in Hole U1417A & $0,10,20$ \\
\hline U1417B & All cores & $0,10,20$ \\
\hline U1417C & All cores & $0,10,20$ \\
\hline U1417D & Sections $13 \mathrm{H}-1,13 \mathrm{H}-2,14 \mathrm{H}-1,14 \mathrm{H}-2,14 \mathrm{H}-3,14 \mathrm{H}-4,15 \mathrm{H}-3$ & $0,5,10,15,20$ \\
\hline U1417D & Sections $53 \mathrm{X}-2,54 \mathrm{X}-1,54 \mathrm{X}-2,54 \mathrm{X}-3,54 \mathrm{X}-4,55 \mathrm{X}-3$ & $0,10,20,25,30$ \\
\hline U1417D & Sections $51 X-1,51 X-2,51 X-3,52 X-3,54 X-1$ & $0,10,20,25,30,35,40$ \\
\hline U1417D & $\begin{array}{l}\text { Sections } 51 X-4,51 X-5,52 X-1,52 X-2,53 X-1,53 X-2,54 X-2,54 X-3,54 X-4,55 X-1,55 X-3,56 X-1,57 X-1,57 X-2,58 X-1, \\
\quad 58 X-2,58 X-3,59 X-1,59 X-2,59 X-5,59 X-6,64 X-1\end{array}$ & $0,10,20,25,30$ \\
\hline U1417D & Section $65 X-1$ & $0,10,20,25$ \\
\hline U1417D & All other cores & $0,10,20$ \\
\hline U1417E & Sections 8R-4, 21R-1, 27R-3, 28R-1, 28R-2, 35R-1, 39R-3, 39R-6 & $0,10,20,25,30$ \\
\hline U1417E & Section 27R-1 & $0,10,20,25$ \\
\hline U1417E & All other cores & $0,10,20$ \\
\hline
\end{tabular}


Table T15. Position of the top (T) and bottom (B) of polarity chronozones and subchronozones, Site U1417.

\begin{tabular}{|c|c|c|c|c|c|c|c|c|c|c|}
\hline \multirow[b]{2}{*}{ Polarity boundary interpretation } & \multirow[b]{2}{*}{$\begin{array}{l}\text { Age } \\
\text { (Ma) }\end{array}$} & & \multicolumn{4}{|c|}{ Hole U1417A } & \multicolumn{4}{|c|}{ Hole U1417B } \\
\hline & & & $\begin{array}{l}\text { Core, section, } \\
\text { interval }(\mathrm{cm})\end{array}$ & $\begin{array}{c}\text { Depth } \\
\text { CSF-A } \\
(\mathrm{m})\end{array}$ & $\begin{array}{l}\text { Depth } \\
\text { CCSF-A } \\
\text { (m) }\end{array}$ & $\begin{array}{l}\text { Depth } \\
\text { CCSF-B } \\
\text { (m) }\end{array}$ & $\begin{array}{l}\text { Core, section, } \\
\text { interval }(\mathrm{cm})\end{array}$ & $\begin{array}{l}\text { Depth } \\
\text { CSF-A } \\
\text { (m) }\end{array}$ & $\begin{array}{l}\text { Depth } \\
\text { CCSF-A } \\
(\mathrm{m})\end{array}$ & $\begin{array}{l}\text { Depth } \\
\text { CCSF-B } \\
\text { (m) }\end{array}$ \\
\hline \multirow[t]{2}{*}{ C1n (B) Matuyama/Brunhes } & 0.781 & Top & $14 \mathrm{H}-5,120$ & 111.60 & 127.00 & 109.86 & $13 \mathrm{H}-1,90$ & 106 & 127.36 & 110.17 \\
\hline & & Base & $14 \mathrm{H}-7,10$ & 113.50 & 128.90 & 111.49 & $13 \mathrm{H}-2,90$ & 107.5 & 128.86 & 111.46 \\
\hline \multirow[t]{2}{*}{ C1r.1n (T) Jaramillo } & 0.988 & Top & $17 \mathrm{H}-2,140$ & 135.80 & 153.13 & 132.46 & & & & \\
\hline & & Base & $17 \mathrm{H}-4,10$ & 137.50 & 154.83 & 133.93 & & & & \\
\hline \multirow[t]{2}{*}{ C1r.1n (B) Jaramillo } & 1.072 & Top & $18 \mathrm{H}-1,130$ & 143.70 & 161.44 & 139.65 & & & & \\
\hline & & Base & $18 \mathrm{H}-3,22.5$ & 144.85 & 162.59 & 140.64 & & & & \\
\hline \multirow[t]{2}{*}{$C 2 n(T)$ Olduvai } & 1.778 & Top & & & & & $23 \mathrm{H}-4,37.5$ & 187.15 & 215.78 & 185.81 \\
\hline & & Base & & & & & $24 \mathrm{H}-2,25$ & 189.25 & 221.34 & 189.92 \\
\hline \multirow[t]{2}{*}{ C2n (B) Olduvai } & 1.945 & Top & & & & & $28 \mathrm{H}-2,22.5$ & 203.93 & 241.63 & 204.92 \\
\hline & & Base & & & & & $28 \mathrm{H}-2,127.5$ & 204.98 & 242.68 & 205.70 \\
\hline \multirow[t]{2}{*}{ C2r.1n (T) Reunion } & 2.128 & Top & & & & & & & & \\
\hline & & Base & & & & & & & & \\
\hline \multirow[t]{2}{*}{ C2r.1n (B) Reunion } & 2.148 & Top & & & & & $34 \mathrm{H}-1,85$ & 224.25 & 267.51 & 224.25 \\
\hline & & Base & & & & & $34 \mathrm{H}-1,125$ & 224.65 & 267.91 & 224.65 \\
\hline \multirow[t]{2}{*}{ C2An.1n (T) Gauss/Matuyama } & 2.581 & Top & & & & & $40 X-3,05$ & 284.2 & 330.68 & 287.42 \\
\hline & & Base & & & & & $40 x-3,60$ & 284.8 & 331.28 & 288.02 \\
\hline
\end{tabular}

\begin{tabular}{|c|c|c|c|c|c|c|c|c|c|c|c|c|c|c|}
\hline \multirow[b]{2}{*}{ Polarity chron interpretation } & \multirow[b]{2}{*}{$\begin{array}{l}\text { Age } \\
(\mathrm{Ma})\end{array}$} & & \multicolumn{4}{|c|}{ Hole U1417C } & \multicolumn{4}{|c|}{ Hole U1417D } & \multicolumn{4}{|c|}{ Hole U1417E } \\
\hline & & & $\begin{array}{l}\text { Core, section, } \\
\text { interval }(\mathrm{cm})\end{array}$ & $\begin{array}{c}\text { Depth } \\
\text { CSF-A } \\
(\mathrm{m})\end{array}$ & $\begin{array}{c}\text { Depth } \\
\text { CCSF-A } \\
(\mathrm{m})\end{array}$ & $\begin{array}{l}\text { Depth } \\
\text { CCSF-B } \\
(\mathrm{m})\end{array}$ & $\begin{array}{l}\text { Core, section, } \\
\text { interval }(\mathrm{cm})\end{array}$ & $\begin{array}{c}\text { Depth } \\
\text { CSF-A } \\
\text { (m) }\end{array}$ & $\begin{array}{l}\text { Depth } \\
\text { CCSF-A } \\
(\mathrm{m})\end{array}$ & $\begin{array}{c}\text { Depth } \\
\text { CCSF-B } \\
(\mathrm{m})\end{array}$ & $\begin{array}{l}\text { Core, section, } \\
\text { interval }(\mathrm{cm})\end{array}$ & $\begin{array}{c}\text { Depth } \\
\text { CSF-A } \\
\text { (m) }\end{array}$ & $\begin{array}{l}\text { Depth } \\
\text { CCSF-A } \\
(\mathrm{m})\end{array}$ & $\begin{array}{l}\text { Depth } \\
\text { CCSF-B } \\
\text { (m) }\end{array}$ \\
\hline C1n (B) Matuyama/Brunhes & 0.781 & $\begin{array}{l}\text { Top } \\
\text { Base }\end{array}$ & & & & & & & & & & & & \\
\hline \multirow[t]{2}{*}{ C1r.1n (T) Jaramillo } & 0.988 & Top & $15 \mathrm{H}-6,110$ & 131.1 & 150.45 & 130.13925 & $16 \mathrm{H}-4,22$ & 133.52 & 153.2 & 132.52 & & & & \\
\hline & & Base & $16 \mathrm{H}-2,105$ & 134.55 & 155.04 & 134.1096 & $16 \mathrm{H}-5,20$ & 135 & 154.68 & 133.8 & & & & \\
\hline \multirow[t]{2}{*}{ C1r.1n (B) Jaramillo } & 1.072 & Top & & & & & $17 \mathrm{H}-2,120$ & 141 & 161.84 & 139.99 & & & & \\
\hline & & Base & & & & & $17 \mathrm{H}-3,10$ & 141.4 & 162.24 & 140.34 & & & & \\
\hline C2n (T) Olduvai & 1.778 & $\begin{array}{l}\text { Top } \\
\text { Base }\end{array}$ & & & & & & & & & & & & \\
\hline C2n (B) Olduvai & 1.945 & $\begin{array}{l}\text { Top } \\
\text { Base }\end{array}$ & & & & & & & & & & & & \\
\hline \multirow[t]{2}{*}{ C2r.1n (T) Reunion } & 2.128 & Top & & & & & $36 \mathrm{H}-2,102$ & 221.32 & 261.63 & 219.70 & & & & \\
\hline & & Base & & & & & $36 \mathrm{H}-3,87$ & 222.68 & 262.99 & 220.71 & & & & \\
\hline C2r.1n (B) Reunion & 2.148 & $\begin{array}{l}\text { Top } \\
\text { Base }\end{array}$ & & & & & & & & & & & & \\
\hline \multirow[t]{2}{*}{ C2An.1n (T) Gauss/Matuyama } & 2.581 & Top & & & & & $45 X-1,55$ & 290.25 & 330.5 & 287.24 & $4 \mathrm{R}-4,25$ & 287.55 & 330.81 & 287.55 \\
\hline & & Base & & & & & $45 X-2,30$ & 291.4 & 331.65 & 288.39 & $4 \mathrm{R}-4,57.5$ & 287.88 & 331.14 & 287.88 \\
\hline C2An.3n (B) Gilbert/Gauss & 3.596 & Transition & & & & & $53 x$ & & & $365 \pm 5$ & & & & \\
\hline C3n.1n (T) Cochiti & 4.187 & Transition & & & & & $54 \mathrm{X}$ & & & $375 \pm 5$ & & & & \\
\hline Middle of $C 3 n .3 n$ (B) Sidufjal to $C 3 n .4 n$ (B) Thvera & 5.017 & Transition & & & & & $59 \mathrm{X}$ & & & $422 \pm 5$ & $8 \mathrm{R}$ to $9 \mathrm{R}$ & & & $418 \pm 5$ \\
\hline C3An.1n (T) & 6.033 & Transition & & & & & & & & & $14 \mathrm{R}$ to $15 \mathrm{R}$ & & & $475 \pm 10$ \\
\hline $\mathrm{C} 3 \mathrm{Bn}(\mathrm{T})$ & 7.14 & Transition & & & & & & & & & $25 \mathrm{R}$ to $27 \mathrm{R}$ & & & $585 \pm 20$ \\
\hline
\end{tabular}


Table T16. Vertical seismic profile direct arrival times, Hole U1417E.

\begin{tabular}{ccccc}
\hline $\begin{array}{c}\text { Receiver depth } \\
\text { WRF }(\mathrm{m})\end{array}$ & $\begin{array}{c}\text { Receiver depth } \\
\text { WRF }(\mathrm{m})\end{array}$ & $\begin{array}{c}\text { Measured one-way } \\
\text { traveltime }(\mathrm{s})\end{array}$ & $\begin{array}{c}\text { Corrected one-way } \\
\text { traveltime }(\mathrm{s})\end{array}$ & $\begin{array}{c}\text { Corrected two-way } \\
\text { traveltime }(\mathrm{s})\end{array}$ \\
\hline 4411.3 & 211.3 & 2.9299 & 2.9357 & 5.8714 \\
4411.9 & 211.9 & 2.9309 & 2.9367 & 5.8734 \\
\hline
\end{tabular}

Measured traveltimes are times between the arrival of the pulse at a hydrophone located $2 \mathrm{~m}$ below the air guns and at the receiver in the borehole. Corrected traveltimes are times between sea level and the borehole receiver. 